\title{
POSTIRRADIATION EXAMINATION OF PEACH BOTTOM \\ FUEL TEST ELEMENT FTE-3
}

\author{
by \\ C. F. WALLROTH, N. L. BALDWIN, \\ C. B. SCOTT and L. R. ZUMWALT *
}

Prepared under

Contract AT(04-3)-167

Project Agreement No. 17

for the

San Francisco Operations Office

U.S. Atomic Energy Commission

*North Carolina State University, Raleigh, North Carolina

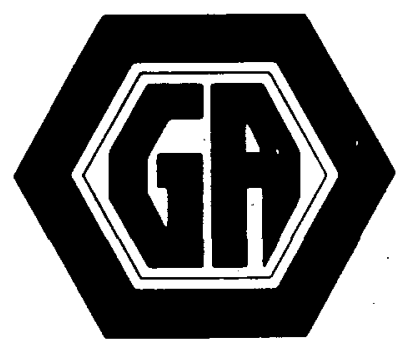

GENERAL ATOMIC 


\section{DISCLAIMER}

This report was prepared as an account of work sponsored by an agency of the United States Government. Neither the United States Government nor any agency Thereof, nor any of their employees, makes any warranty, express or implied, or assumes any legal liability or responsibility for the accuracy, completeness, or usefulness of any information, apparatus, product, or process disclosed, or represents that its use would not infringe privately owned rights. Reference herein to any specific commercial product, process, or service by trade name, trademark, manufacturer, or otherwise does not necessarily constitute or imply its endorsement, recommendation, or favoring by the United States Government or any agency thereof. The views and opinions of authors expressed herein do not necessarily state or reflect those of the United States Government or any agency thereof. 


\section{DISCLAIMER}

Portions of this document may be illegible in electronic image products. Images are produced from the best available original document. 
$$
\text { . }
$$ 
ABSTRACT

FTE-3 was a phase II fuel test element in Peach Bottom Unit 1, Core 2. Beginning-of-life (BOL) for phase II was 252 equivalent full-power days (LFPJ) of Core 2 operation. FTE-3 was irradiated for 133 EFPD, accumulating a fast fluence of $0.6 \times 10^{21} \mathrm{n} / \mathrm{cm}^{2}(\mathrm{E}>0.18 \mathrm{MeV})$ and a thermal fluence of $0.66 \times 10^{21} \mathrm{n} / \mathrm{cm}^{2}(\mathrm{E}<2.83 \mathrm{eV})$ at an irradiation average peak fuel temperature of $913^{\circ} \mathrm{C}$. Calculated peak burnup was $11.3 \%$ fissions per initial metal atom (FIMA) for fissile and 0.057\% FIMA for fertile material.

After removal from the core, the element was $\gamma$-scanned for fuel stack length determination. It was then shipped to the Hot Cells of General Atomic Company, San Diego, California, for postirradiation examinations. No failure of graphite and fuel components was found. Although FTE-3 had a short irradiation exposure, the results on dimensional changes, especially on fuel rods, are considered to be most valuable because the large number of samples provided statistical confidence for improvement of computer code models near start-of-life conditions. Evaluation of fuel rod and graphite dimensional measurements also allowed determination of integral gap behavior, which is valuable for heat transfer and interaction considerations.

The hot injected fuel rods can be split into four different blends with a11 TRISO and TRISO/BISO fissile-fertile fuel. All four blends have been inspected destructively and nondestructively for failure determination by fission gas annealing, metallography, and the electrolytic disintegrationacid leach technique. A coated particle failure of less than $1.0 \%$ was determined from these examinations.

Thermal stability samples from spine positions were analyzed by radiography and metallography. No signs of fuel kernel migration or other 
thermochemical effects were found. This was also the case for the examined fuel rods.

Metallic diffusion samples, irradiated in spine positions, allowed the determination of diffusion profiles for cesium, strontium, europium, and barium; permeability coefficients; partition coefficients; and diffusion coefficients. The addition of a gettering material such as $\mathrm{MgF}_{2}$ was found to be effective only in retaining strontium.

Fission product release samples were sectioned for partition coefficient determination. The results were consistent with the diffusion sample data. Silicon-doping of BISO coatings was found not to be effective in metallic fission product retention. Oxide BISO fuel particles did retain cerium, however, and showed higher cesium release than carbide fuel. 
CONTENTS

ABSTRACT . . . . . . . . . . . . . . . . . . . . . iii

1. INTRODUCTION . . . . . . . . . . . . . . . . . . . 1

2. IRRADIATION CONDITIONS . . . . . . . . . . . . . . 3

2.1. Irradiation History . . . . . . . . . . . . . 3

2.2. Fluence ..................... 3

2.3. Temperature . . . . . . . . . . . . . . . 4

2.3.1. Temperature Calculations............ 4

2.3.2. Temperature Measurements . . . . . . . . 5

2.4. Burnup . . . . . . . . . . . . . . . . . . . 8

3. GAMMA SCAN RESULTS . . . . . . . . . . . . . . . . . . . 11

4. POSTIRRADIATION EXAMINATION AND RESULTS . . . . . . . . . . 13

4.1. Disassembly Operations . . . . . . . . . . . . . 13

4.2. Fuel Element Sleeve Examination . . . . . . . . . 15

4.3. Fuel Body Examination . . . . . . . . . . . . . 15

4.3.1. Graphite Integrity and Dimensional Changes . . . 15

4.3.2. Autoradiography . . . . . . . . . . . 17

4.4. Fue1 Rod Irradiation Performance . . . . . . . . . . 18

4.4.1. Sample Description . . . . . ...... 18

4.4.2. Visual Examination ............ 19

4.4.3. Fuel Rod Dimensional Changes ......... . . 19

4.4.4. Fission Gas Release Measurements . . . . . . . 23

4.4.5. Metallographic Examination . . . . . . . . 24

4.4.6. Electrolytic Disintegration - Acid Leaching
Studies . . . . . . . . . . . 24

4.5. Thermal Stability Spine Samples . . . . . . . . . 26

4.5.1. Test Configuration ............. 26

4.5.2. Visual Examination .. . . . . . . . . 27

4.5.3. Radiography .... . . . . . . . . 27

4.5.4. Metallography ............. 28 
CONTENTS (Contd)

4.6. Metallic Diffusion Samples . . . . . . . . . 28

4.6.1. Experimental Procedures........... 29

4.7. Fuel Particle Fission Product Release Samples . . . . . . 39

4.7.1. Experimental Procedure . . . . . . . . . 39

5. CONCLUSTON . . . . . . . . . . . . . . . . . 43

REFERENCES . . . . . . . . . . . . . . . . . . . 47

APPENDIX A FIGURES

1. Peach Bottom unit 1 reactor history .............. . 49

2. FTE-3 calculated temperature and fluence profiles, evaluated average during life temperature profile . . . . . . . .

3. FTE-3 calculated fuel centerline, sleeve outside surface and coolant temperature (BOL) . . . . . . . . . . . . 51

4. Correction terms for W/Re thermocouple permutation . . . . . . 52

5. Temperature history from thermocouple readings for FTE-3 . . . 53

6. FTE-3 gamma scan trace . . . . . . . . . . . . . . . . 54

7. Fuel element identification FTE-3 (mirror image) . . . . . . 55

8. FTE-3 fuel element serial number 887 (mirror image) . . . . . . 55

9. FTE-3 composite photograph of total element (mirror image) . . 57

10. FTE-3 internal trap, upper end view (mirror image) . . . . . 59

11. Bottom fuel body (1) from FTE-3 (mirror image) . . . . . . . 60

12. Center fuel body (2) from FTE-3 (mirror image) . . . . . . . 61

13. Top fuel body (3) from FTE-3 . . . . . . . . . . . . . 62

14. FTE-3 graphite body sampling plan for inside diameter
measurements and autoradiography. . . . . . . . 63

15. FTE-3 bottom fuel body sections . . . . . . . . . . . . 64

16. FTE-3 center fuel body sections . . . . . . . . . . . . 65

17. FTE-3 top fuel body sections . . . . . . . . . . . . 66

18. Autoradlographs from bottom body FTE-3/1 . . . . . . . . . 67

19. Autoradlographs from center body FTE-3/2 . . . . . . . . 68 


\section{FIGURES (Contd)}

20. Autoradiographs from top body FTE-3/3 . . . . . . . . . 69

21. FTE-3 fuel rod 1-1-9 visual examination . . . . . . . . . 70

22. FTE-3 fuel rod 2-8-7 visual examination . . . . . . . . . . 71

23. FTE-3 fuel rod $2-3-7$ visual examination . . . . . . . . . . 72

24. FTE-3 fuel rod 2-5-7 visual examination . . . . . . . . . 73

25. FTE-3 fuel rod dimensional changes for $\mathrm{UO}_{2} \mathrm{TRISO} \mathrm{ThO}_{2} \mathrm{BISO}$ fuel (holes 1 and 2) . . . . . . . . . . . . . 74

26. FTE-3 fuel rod dimensional changes for (2.75 Th:U) $\mathrm{C}_{2}$ TRISO, $\mathrm{ThC}_{2}$ BISO fuel (holes 3 and 4)............. 75

27. FTE-3 fuel rod dimensional changes for (2.75 Th:U) $C_{2}$ TRISO, $\mathrm{ThC}_{2}$ TRISO fuel (holes 5 and 6) ............ 76

28. FTE-3 fuel rod dimensional changes for $\mathrm{UC}_{2}$ TRISO, ThC 2 BISO fuel (holes 7 and 8) . . . . . . . . . . . . . 77

29. FTE-3 photomicrographs of fuel rod 2-3-7.......... . 79

30. FTE-3 photomicrographs of representative particles from fuel $\operatorname{rod} 2-3-7$. . . . . . . . . . . . . . 81

31. FTE-3 photomicrographs of fuel rod 2-2-7 . . . . . . . . . 83

32. FTE-3 photomicrographs of representative particles from fuel

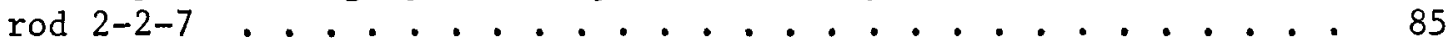

33. FTE-3 photomicrographs of fuel rod 2-8-7. . . . . . . . 87

34. FTE-3 photomicrograph of representative particles from fuel rod 2-8-7........................... 89

35. FTE-3 photomicrographs of fuel rod 2-5-7 . . . . . . . . . 90

36. FTE-3 photomicrographs of representative particles from fuel $\operatorname{rod} 2-5-7$. . . . . . . . . . . . . . . . 91

37. Fuel rod disintegration unit for dissociation of irradiated fue1 rods . . . . . . . . . . . . . . . . . . 92

38. Disintegration chamber for electrolytic dissociation of fuel rods in an acid medium . . . . . . . . . . . . 93

39. FTE-3 electrolytic disintegration of fuel rod 1-8-7 . . . . . . 94

40. FTE-3 electrolytic disintegration of fuel rod 1-8-8 . . . . . 95

41. FTE-3 metallography on fuel rod 1-8-7 particles after electrolytic disintegration ............ . 9 96

42. FTE-3 metallography on fuel rod 1-8-8 particles after electrolytic disintegration . . . . . . . . . . 97

43. Design of type 1 thermal stability outer crucibles . . . . . . 98 
FIGURES (Contd)

44. Design of type 1 thermal stability inner crucibles . . . . . . 99

45. Design of type 2 thermal stability crucibles . . . . . . . . 100

46. FTE-3 thermal stability spine sample $\mathrm{K}$, visual examination . . 101

47. FTE-3 thermal stability spine sample L, visual examination . . 102

48. FTE-3 thermal stability spine sample 5, visual examination . . 103

49. FTE-3 thermal stability spine sample 17, visual examination . . 104

50. FTE-3 thermal stability spine sample L, microradiographs . . . . 105

51. FTE-3 thermal stability spine sample 17, metallography . . . . 106

52. FTE-3 thermal stability spine sample 29-3, metallography . . . 107

53. FTE-3 thermal stability spine sample 29-2, metallography . . . 108

54. FTE-3 thermal stability spine sample 29-6, metallography . . . . 109

55. Design of diffusion spine samples . . . . . . . . . . . 110

56. FTE-3-3 crucible wall Cs-134 . . . . . . . . . . . . . . . 111

57. FTE-3-3 center post $\mathrm{Cs}-134$. . . . . . . . . . . . . . 113

58. FTE-3-11 crucible wall Cs-134 . . . . . . . . . . . . 115

59. FTE-3-16 crucible wall $\mathrm{Cs}-134$. . . . . . . . . . . 116

60. FTE-3-16 center post $\mathrm{Cs}-134$. . . . . . . . . . . 117

61. FTE-3-24 crucible wall cs-134 . . . . . . . . . . . . . 118

62. FTE-3-42 crucible wall Cs-134 . . . . . . . . . . . . 119

63. FTE-3-42 center post Cs-134 . . . . . . . . . . . . . . . 121

64. FTE-3-45 crucible wall Cs-134 . . . . . . . . . . . . . . 123

65. FTE-3-45 center post Cs -134 . . . . . . . . . . . . . 125

66. FTE-3-55 crucible wall $\mathrm{Cs}-134$. . . . . . . . . . . . 126

67. FTE-3-55 center post Cs-134 . . . . . . . . . . . . 128

68. FTE-3-63 crucible wall $\mathrm{Cs}_{s-134}$. . . . . . . . . . . . 130

69. FTE-3-63 center post $\mathrm{Cs}-134$. . . . . . . . . . . . 131

70. FTE-3-66 center post Cs-134 . . . . . . . . . . . . . 132

71. Cesium fast-component permeation coefficients from FTE-3 diffusion samples . . . . . . . . . . . . . 134

72. FTE-3-11 center post $\mathrm{Sr}-85$. . . . . . . . . . . . . . . 135

73. FTE-3-16 crucible wa11 Sr-85 . . . . . . . . . . . . 136

74. FTE-3-16 center post $\mathrm{Sr}-85$. . . . . . . . . . . . 138 
FIGURES (Contd)

75. FTE-3-42 crucible wall Sr-85 . . . . . . . . . . . . 140

76. FTE-3-42 center post $\mathrm{Sr}-85$. . . . . . . . . . . . . 141

77. FTE-3-45 crucible wall Sr-85 . . . . . . . . . . . . . 142

78. FTE-3-45 center post Sr-85 . . . . . . . . . . . . . . . . 143

79. FTE-3-55 crucible wall Sr-85 . . . . . . . . . . . . 144

80. FTE-3-55 center post $\mathrm{Sr}-85$. . . . . . . . . . . . . 145

81. FTE-3-63 center post $\mathrm{Sr}-85$. . . . . . . . . . . . . 146

82. FTE-3-66 center post $\mathrm{Sr}-85$. . . . . . . . . . . . . . 147

83. FTE-3-24 crucible wall Eu-154 . . . . . . . . . . . 148

84. FTE-3-24 center post Eu-154 . . . . . . . . . . . . . 149

85. FTE-3-42 crucible wall Eu-154 . . . . . . . . . . . . 150

86. FTE-3-42 center post Eu-154 . . . . . . . . . . . . . . . 151

87. FTE-3-45 crucible wall Eu-154 . . . . . . . . . . . . . . 152

88. FTE-3-45 center post Eu-154 . . . . . . . . . . . . . . . . . 154

89. FTE-3-55 crucible wall Eu-154 . . . . . . . . . . . . 156

90. FTE-3-55 center post Eu-154 . . . . . . . . . . . . 157

91. FTE-3-42 crucible wall Ba-133 . . . . . . . . . . . . 158

92. FTE-3-42 center post Ba-133 . . . . . . . . . . . . . . 159

93. FTE-3-45 crucible wall Ba-133 . . . . . . . . . . . 160

94. FTE-3-45 center post Ba-133 . . . . . . . . . . . . . . 162

95. FTE-3-55 crucible wall Ba-133 . . . . . . . . . . . . . 163

96. FTE-3-55 center post Ba-133 . . . . . . . . . . . . . . 164

97. FTE-3-63 center post $\mathrm{Ba}-133$. . . . . . . . . . . . . 165

98. FTE-3-66 center post Ba-133 . . . . . . . . . . . . . 166

99. Diffusion coefficients of $\mathrm{Sr}, \mathrm{Eu}$, and $\mathrm{Ba}$ from FTE-3 diffusion samples .................... 167

100. Design of type 1 fission product release spine samples:
outer crucible (graphite) above, and inner crucible below . . 168

101. Design of fission product release spine samples: outer crucible (nioblum) above, and inner crucible below . . . . . 169 
APPENDIX B TABLES

1. FTE-3 average thermocouple readings . . . . . . . . . . . 171

2. $\Delta T$ correction for thermocouple readings and centerline fuel temperature . . . . . . . . . . . . . . . . . 172

3. FTE-3 centerline fuel temperature from thermocouple readings and correction .................... . . 173

4. FTE-3 average nuclide weights for fuel rods, spine samples, and total element . . . . . . . . . . . . . . . 174

5. FTE-3 average calculated burnup . . . . . . . . . . . . 175

6. Summary of temperature and burnup evaluation for FTE-3 . . . . . 176

7. FTE-3 fuel stack dimensional changes . . . . . . . . . . 177

8. FTE-3 thermocouple resistance measurements . . . . . . . . 178

9. Distance $d$ from top of spine to edge of hole in FTE-3 . . . . . . 179

10. FTE-3 spine samples . . . . . . . . . . . . . . . 180

11. FTE-3 fuel stack measurements . . . . . . . . . . . . . 181

12. FTE-3 sleeve measurements . . . . . . . . . . . . . . 182

13. FTE-3 fuel body data (Ref. Dwg. 11504) . . . . . . . . . 183

14. FTE-3 fuel body data (Ref. Dwg. 11505) . . . . . . . . . 184

15. FTE-3 fuel body data (Ref. Dwg. 11506) . . . . . . . . . 185

16. Description and location of slices taken from FTE-3 graphite bodies for autoradiography . . . . . . . . . . . . 186

17. Description of fuel particles used for fuel rods in FTE-3 . . . 187

18. Fuel rod dimensional change evaluation for FTE-3 . . . . . . . 188

19. FTE-3 anisotropy in fuel rod dimensional changes . . . . . . . 189

20. FTE-3 axial gap increase between fuel rods . . . . . . . . . . 190

21. FTE-3 radial gap increase between fuel rod and graphite . . . . . 191

22. Composition and fission gas release $R / B$ data for fuel rods irradiated in FTE-3 . . . . . . . . . . . . . . . . . 192

23. Results of postirradiation fission gas release measurements and electrolytic disintegration - acid leach studies on selected fuel rods irradiated in FTE-3 . . . . . . . . . . . . 193 
TABLES (Contd)

24. Type I thermal stability samples irradiated in FTE-3 and subsequently examined ...................

25. Type II thermal stability samples irradiated in FTE-3 and subsequently examined . . . . . . . . . . . . . 195

26. Data on FTE-3 diffusion spine crucibles . . . . . . . . . 196

27. Nuclear transformations of metal diffusants . . . . . . . . . 197

28. Results of FTE-3 data analysis of concentration profiles cesium fast component . . . . . . . . . . . . . . . 198

29. Results of analysis of FTE-3 concentration profiles - cesium slow component. . . . . . . . . . . . . . . . . . .

30. Results of analysis of FTE-3 concentration profiles strontium diffusion.................. 200

31. Results of analysis of FTE-3 concentration profiles - europium (samarium) diffusion .................. 201

32. Results of analysis of FTE- 3 concentration profiles - barium diffusion ...................... 202

33. Description of fuel particles used in graphite-canned fission product release samples irradiated in FTE-3 . . . . . . . . . 203

34. Cesium partition coefficients from FTE-3 fission product release samples . . . . . . . . . . . . . . 204

35. Description of fuel particles used in niobium-canned fission product release samples irradiated in FTE-3 . . . . . . . 205

36. Thermal analysis of niobium-canned fission product release samples ( $\mathrm{No} . \mathrm{Nb}-3, \mathrm{Nb}-6, \mathrm{Nb}-10$, and $\mathrm{Nb}-14$ ) irradiated in FTE-3 206

37. Distribution of $\mathrm{Cs}-137, \mathrm{Ce}-144$, and $\mathrm{Zr}-95$ in fission product release samples irradiated in FTE-3. . . . . . . . . . . . 


\section{INTRODUCTION}

Fuel test element FTE-3 is one of a group of test elements irradiated in the Peach Bottom High-Temperature Gas-Cooled Reactor (HTGR). The fuel test element program was designed to provide information on the behavior of HTGR fuels subjected to representative irradiation conditions. For this purpose, Peach Bottom Reactor Unit 1 was a unique facility with regard to neutron spectrum, pressurized helium environment, and temperature regime. The main test objectives for the fuel test elements are (Ref. 1):

1. Evaluate the performance of HTGR fuels over a wide range of operating conditions and lifetimes.

a. Determine the time-at-temperature lifetimes of various types of fuel.

b. Obtain data to identify mechanisms of particle deterioration under extreme conditions and thereby improve fuel performance and lifetimes.

c. Evaluate various production processes.

2. Conduct controlled irradiation experiments on:

a. Fuel particle thermal stability.

b. Metallic fission product diffusion rates in an HTGR environment.

c. Graphite mechanical and creep properties. 
d. Fission product release of various types of fuel particles.

e. Various fuel rod fabrication concepts.

3. Evaluate the long-term, in-pile performance of blended beds and bonded rods under HTGR conditions.

An overall program and experiment design description is given by Steward (Ref. 1). Actual design information on FTE-3 is documented in the "as built" assembly drawings (No. 11495) and other unpublished documents.

After termination of irradiation, FTE-3 was sent to the Hot Cells of General Atomic Company, San Diego, California, for postirradiation examination. This report presents the evaluation of the irradiation conditions, the different stages of postirradiation examinations, and the correlation of the findings with the irradiation conditions. 


\section{IRRADIATION CONDITIONS}

\subsection{IRRADIATION HISTORY}

Fuel test element FTE-3 was irradiated in Peach Bottom Core 2 in core position A03-03 from July 11, 1971, the beginning of life (BOL), at 252 equivalent full-power days (EFPD) (Core 2) until January 7, 1972, the endof-life (EOL), at 385 EFPD. FTE-3 accumulated 133 EFPD under reactor conditions. This is shown in Fig. 1, which gives reactor thermal power and thermal reactor energy versus time and includes shutdowns. An EFPD is based on 115 MW $(t)$ power for the Peach Bottom reactor.

\subsection{FLUENCE}

Calculated fast and thermal fluence profiles in axial direction are shown in Fig. 2. They were hand-calculated from average flux profiles as given by the Peach Bottom FEVER code on a 100 EFPD-of-operation basis.

The fluence peak values were:

$$
\begin{array}{ll}
\text { EOL peak fast fluence } & 0.60 \times 10^{21}\left(\mathrm{n} / \mathrm{cm}^{2}, E>0.18 \mathrm{MeV}\right) \\
\text { EOL peak thermal fluence } & 0.66 \times 10^{21}\left(\mathrm{n} / \mathrm{cm}^{2}, E<2.38 \mathrm{eV}\right)
\end{array}
$$

A breakdown in fluences for each fuel rod at different axial positions is given as additional information in Table 18 for fast fluence and in Table 6 for thermal fluence. All values are calculated and not verified by measurements. 


\subsection{TEMPERATURE}

\subsubsection{Temperature Calculations}

Figure 2 shows the calculated axial centerline fuel and center sample temperature distributions for the BOL situation. The axial temperature distribution is based on reactor operation at 95\% power [i.e., $109 \mathrm{MW}(\mathrm{t})$ ] and $105 \%$ flow (i.e., $5 \times 10^{5} \mathrm{lb} / \mathrm{hr} \equiv 2.27 \times 10^{5} \mathrm{~kg} / \mathrm{hr}$ ). These values reflect operational conditions prevailing throughout the lifetime of FTE-3 (also see Fig. 1). The BOL prevailing control rod configuration remained nearly constant until 342 EFPD in Core 2 (90 EFPD for FTE-3 as of October 31, 1971) when a control rod configuration change was realized. After this change, the FTE-3 1inear heat rate decreased about $10 \%$ and then remained constant until EOL. Power factors relative to the operational average of all 804 fuel elements in Peach Bottom are given in Table 1.

The BOL and EOL calculations gave nearly the same temperature results (about $20^{\circ} \mathrm{C}$ less peak temperature at EOL) because decreasing power was compensated for by decreasing the thermal conductivity of the graphite by assuming $25 \mathrm{Btu} / \mathrm{hr}-\mathrm{ft}-{ }^{\circ} \mathrm{F}\left(0.1 \mathrm{cal} / \mathrm{sec}-\mathrm{cm}-{ }^{\circ} \mathrm{C}\right)$ and $16 \mathrm{Btu} / \mathrm{hr}-\mathrm{ft}-{ }^{\circ} \mathrm{F}(0.07$ $\mathrm{cal} / \mathrm{sec}-\mathrm{cm}-{ }^{\circ} \mathrm{C}$ ) for $\mathrm{BOL}$ and EOL, respectively. Therefore the temperatures shown in Fig. 2 approximate fuel temperatures throughout the FTE-3 irradiation lifetime, as far as can be deduced from thermohydraulic calculations. (Thermocouple results indicate a different behavior, as discussed in Section 2.3.2.)

The axial temperature profiles were obtained from the TES code, a one-dimensional code for Peach Bottom test elements (Ref. 2) which does not treat the axial interruptions in the fuel where the individual fuel bodies meet. Although these end effects are localized, steep axial thermal gradients at the ends of the fuel bodies can be expected as shown in earlier calculations and as indicated in Fig. 2. The axial profiles for fuel centerline sleeve outside surface and coolant temperatures are shown in Fig. 3 as calculated for BOL. The following peak values were determined: 
BOL peak fuel temperature

BOL peak center sample temperature $2134^{\circ} \mathrm{F}\left(1168^{\circ} \mathrm{C}\right) \pm 100^{\circ} \mathrm{C}$

$2014^{\circ} \mathrm{F}\left(1101^{\circ} \mathrm{C}\right) \pm 100^{\circ} \mathrm{C}$

From thermocouple readings (see Section 2.3.2):

Average during life peak fuel

temperature:

$1668^{\circ} \mathrm{F}\left(913^{\circ} \mathrm{C}\right) \pm 100^{\circ} \mathrm{C}$

Average during life peak center

sample temperature:

$1591^{\circ} \mathrm{F}\left(866^{\circ} \mathrm{C}\right) \pm 100^{\circ} \mathrm{C}$

\subsubsection{Temperature Measurements}

FTE-3 was assembled with the following two thermocouples at 75.5 in. total height (i.e., 49.5 in. active core height):

One W/Re type near center spine samples (TC-A)

One C/A type near outer sleeve positon (TC-B)

Readings, recorded on a weekly basis, were corrected for:

1. Changes in cold junction temperatures ("standoff pin temperature") for both types (automatically carried out at Peach Bottom).

2. Adjustment in calibration equipment (for W/Re type only), where readings are $40^{\circ} \mathrm{F}$ too high because of change from $\mathrm{W}-5 \% \operatorname{Re} / \mathrm{W}-26 \% \operatorname{Re}$ type to $W-3 \% \operatorname{Re} / \mathrm{W}-25 \% \operatorname{Re}$ type.

3. Decalibration of $\mathrm{W} / \mathrm{Re}$ type because of permutation of emf output by neutron bombardment. 
The latter is suggested to be a function of thermal fluence, for which the following correction has been derived from capsule experiments (Refs, 2,3):

$$
T_{a}=\frac{T_{i}-A(\psi)}{B(\psi)}
$$

where

$$
\begin{aligned}
& \mathrm{T}_{\mathrm{a}}=\text { actual temperature (corrected signal), }{ }^{\circ} \mathrm{C}, \\
& \mathrm{T}_{\mathrm{i}}=\text { irradiation temperature (uncorrected signal), }{ }^{\circ} \mathrm{C}, \\
& \mathrm{A}(\psi)=0.183+(3.02-0.215 \cdot \psi),{ }^{\circ} \mathrm{C}, \\
& \mathrm{B}(\psi)=0.993-(0.201-0.009 \cdot \psi), \text { dimensionless, } \\
& \psi \quad=\text { thermal fluence, } 10^{21} \mathrm{n} / \mathrm{cm}^{2}(\mathrm{E}<2.38 \mathrm{eV}),
\end{aligned}
$$

The two correction terms $A(\psi)$ and $B(\psi)$ are plotted in Fig. 4. The corrected thermocouple readings versus time are shown in Fig. 5. Permutation corrections for the $\mathrm{W} / \mathrm{Re}$ thermocouple are up to $55^{\circ} \mathrm{C}$, which is also indicated in Fig. 5 .

Four different time phases can be distinguished, as summarized in Table 1. The average readings for the W/Re-type thermocouple decrease with time. For the C/A-type thermocouple, the readings are nearly constant except for a single possible temperature spike at BOL. Comparison of the temperature difference between two corresponding thermocouples and the calculated difference (deduced from Table 2) show poor agreement.

Table 2 gives the calculated corrections (Refs. 2, 4) for different element power factors and lifetimes, by which the centerline fuel temperature (at the same axial position as the thermocouples) can be deduced 
from the thermocouple reading. This has been done for the four different time phases during the FTE-3 irradiation (see Table 3 and Fig. 5).

Agreement between the fuel temperatures based on the $\mathrm{C} / \mathrm{A}$ and $\mathrm{W} / \mathrm{Re}$ thermocouple readings is in the range of $20^{\circ} \mathrm{C}$ to $55^{\circ} \mathrm{C}$, which seems to be reasonable considering the raw nature of interpolation used. Typical temperature differences between thermocouple readings and fuel centerline temperatures are $250^{\circ} \mathrm{C}$ and $100^{\circ} \mathrm{C}$ for the $\mathrm{C} / \mathrm{A}$ and $\mathrm{W} / \mathrm{Re}$ types, respectively.

The thermocouple-derived peak fuel temperature near BOL confirms the temperature level as derived from physics calculations; however, this is based on only one measurement and therefore is questionable. Otherwise, there must have been a drastic change between time phases 1 and 2 since the peak fuel temperatures for time phases 2, 3 , and 4 are at the $900^{\circ} \mathrm{C}$ level in comparison with $1200^{\circ} \mathrm{C}$ in phase 1.

The following conclusions can be drawn from the temperature evaluation:

1. The overall tendency is decreasing temperature with time.

2. Thermocouple readings indicate an average (during life) peak fuel temperature of $913^{\circ} \mathrm{C} \pm 100^{\circ} \mathrm{C}$, which remains in disagreement with a calculated average (during life) peak fuel temperature of $1168^{\circ} \mathrm{C} \pm 100^{\circ} \mathrm{C}$.

3. The discrepancy between predicted and measured temperatures can be interpreted to mean that local power factors are about $30 \%$ lower than anticipated $\left(344^{\circ} \mathrm{C}\right.$ gas entry temperature):

$$
\frac{913-344}{1168-344}=0.69 \text {. }
$$

By this means, temperature profiles in Fig. 2 have to be downrated when thermocouple readings are used. This leads to $46^{\circ} \mathrm{C}$ 
lower peak center sample temperatures as compared with $67^{\circ} \mathrm{C}$ as calculated. Table 6 includes BOL-calculated $T_{1}$ and downrated average $\mathrm{T}_{2}$ fuel temperatures for each fuel rod at different axial locations $Z$ according to

$$
\mathrm{T}_{2, \mathrm{Z}}=\left(\mathrm{T}_{1, \mathrm{Z}}-344\right) 0.69-344\left({ }^{\circ} \mathrm{C}\right)
$$

4. Preirradiation and postirradiation thermocouple resistance measurements are in very good agreement (see Section 4) so that malfunctioning can be excluded. (Misconnection of thermocouples at Peach Bottom can, however, be possible.)

5. For this report, the evaluated temperatures as derived from the thermocouple readings have been used as reference temperatures.

\subsection{BURNUP}

The burnup is defined as fissions per initial metal atom (FIMA). Fissions are the difference between initial (index 0 ) and final (index $i$ ) metallic atoms $X$. They are proportional to the nuclide weights $G$ over the atomic weights $\mathrm{A}$ :

$$
X \sim \frac{G}{A}
$$

The following different FIMA values can be quoted:

1. For the fissile material with $U_{i}$ as sum of all uranium (except $\mathrm{U}-233$ ) and $\mathrm{Pu}$ atoms,

$$
\text { FIMA fiss. }=\frac{\mathrm{U}_{0}-\mathrm{U}_{i}}{\mathrm{U}_{0}} \equiv \mathrm{F}_{1} .
$$


2. For the fertile material with $\mathrm{Th}_{1}$ as sum of all thorium, $\mathrm{Pa}-233$, and U-233 atoms,

$$
\text { FIMA }_{\text {fert. }}=\frac{T h_{0}-T h_{i}}{T h_{0}} \equiv F_{2} .
$$

3. For the total heavy metals,

$$
\text { FIMA }_{\text {total }}=\mathrm{F}_{1} * \mathrm{x}+\mathrm{F}_{2} *(1-\mathrm{x}) \text { - } \mathrm{F}_{3}
$$

with

$$
x=\frac{U_{0}}{U_{0}+T h},
$$

and if different blends $j$ with different thorium loadings are used,

$$
\text { FIMA total, } j=\text { FIMA }_{\text {total }} * y
$$

with

$$
y=\frac{F_{1} * x_{j}+F_{2} *\left(1-x_{j}\right)}{F_{1} * x+F_{2} *(1-x)} .
$$

Fissile FIMA $F_{1}$ and fertile FIMA $F_{2}$ do not change with different blend types.

4. For kernels with mixed fuel of a Th:U $=N$ atomic ratio,

$$
\text { FIMA }_{\text {mixed }}=\frac{1}{1+N} *\left(F_{1}+N * F_{2}\right) \equiv F_{4}
$$

The fuel loadings for FTE-3 are given in Table 4. The element contained four different blend types with one blend per two fuel holes. The amount of fissile material was the same in all four blends; the amount of fertile material was different. Additional heavy metal was located in the 
center spine samples. EOL total element loading has been taken from physics calculations, using the GAUGE code (Ref. 5). Linear corrections had to be made for the fertile loading, which happened to be $6.6 \%$ too low for BOL in the calculation against the as-loaded figures. Average EOL fuel rod and spine sample loadings had been calculated by applying the EOL/BOL nuclide ratio as calculated for the total element. Pu weights had been neglected. Average burnup values and additional correlation factors are given in Table 5 according to Eqs. 3 through 9.

Assuming burnup is directly proportional to the thermal fluence, the average FIMA values are multiplied with the normalized fluence profile in order to achieve individual values for fuel rods at different axial locations. Results of these burnup calculations are given in Table 6 together with temperature and thermal fluence data. The total FIMA applies to the total test element. Values for the different fuel blends have to be calculated from Eq. 7, using the correlation factor y from Table 5.

The burnup calculation produced the following peak and average values:

\begin{tabular}{l|c|c}
\hline & Peak (\%) & Average (\%) \\
\hline FIMA, fissile & 11.3 & 8.7 \\
FIMA, mixed Th:U = 2.75 & 3.0 & 2.3 \\
FIMA, fertile & 0.06 & 0.04 \\
FIMA, total element & 2.0 & 1.5 \\
\hline
\end{tabular}

Actual burnup measurements are planned for profile and method verification and error determination. If the burnup measurements are significantly lower than the calculations, overestimation of local power factor as deducible from temperature evaluation would be confirmed. 


\section{GAMMA SCAN RESULTS}

After removal during 385 EFPD shutdown, FTE-3 was gamma-scanned at Peach Bottom for determination of the fueled length. This was done by the Peach Bottom standard procedure, in which the fuel element is slowly raised into (or lowered from) the charge machine, passing a collimator slit in the radial shielding. Gamma radiation that traverses the collimator path is detected by a scintillation crystal multiplier assembly and amplified. Both the count rate and the element position are recorded simultaneiously on a strip chart, from which the actual measurement of the fueled length is obtained.

The gamma-scan strip chart for FTE-3 is shown in Fig. 6. The average transverse distance (Ref.6) (i.e., averaged over the whole fueled length of $90 \mathrm{in.)}$ is $3.2432 \mathrm{in.} \pm 0.0036 \mathrm{in.}$, where the $+0.0036 \mathrm{in}$. applies to the bottom end and the -0.0036 in. to the top end of the fueled length. These corrections are caused by the change in the vertical velocity of the fuel elements, during measurements, that originates from the finite thickness of the charged machine lifting tapes, which are wound on the drum.

For FTE-3 with three equal-length fuel bodies, the average transverse distance for each body is:

$$
3.2432\left\{\begin{array}{ll}
+0.0024 & \text { in. } \text { bottom fuel body } \\
+0 & \text { in. } \text { center fuel body } \\
-0.0024 & \text { in. top fuel body }
\end{array} \mid=\left(\begin{array}{l}
+0.07 \% \\
+0 \\
-0.07 \%
\end{array} \mid\right. \text {. }\right.
$$

The gamma-scan results are summarized in Table 7 together with comparative measurements. The bottom and top fuel body measurements agree fairly well with length changes deduced from plenum measurements (i.e., the free 
distance between the fuel stack and the end of the graphite fuel body). Averaged radial and axial fuel rod measurements (i.e., shrinkage values) are up to $100 \%$ higher than the plenum measurements because of the different nature of these measurements. One chip between two fuel rods could change a total stack length measurement significantly; concave end cap effects, increased during irradiation, would show up in individual rod measurements but not in overall stack length. They can be explained as axial gap increases during irradiation (see 4.4.3). Therefore, it is not surprising that the plenum and gamma scan measurements show lower shrinkage values than the radial and axial fuel rod measurements in Table 7 . In future postirradiation examinations, the lengths of the recomposited fuel rod stacks will be measured.

The $-0.3 \%$ gamma-scan result for the center fuel body compared with the $-0.8 \%$ plenum and $-1.4 \%$ fuel rod measurements, however, is far out of range, contradicting theory and experience. The center body with the highest flux levels should show the highest shrinkage values, especially for shortterm irradiations as in FTE-3. All other measurements in Table 7 confirm this tendency except this single gamma-scan result. Therefore, an evaluation error is suspected. Unfortunately, the original gamma-scan strip chart is not available, but even the reduced copy in Fig. 6 indicates a value on the order of $-1 \%$.

The following conclusions can be drawn from the gamma-scan results:

1. Gamma-scanning gives a reasonable indication of fueled stack length changes during irradiation.

2. Fuel rod dimensional change data should be obtained from individual rod measurements. 


\section{POSTIRRADIATION EXAMINATION AND RESULTS}

\subsection{DISASSEMBLY OPERATIONS}

Upon arrival from Peach Bottom, the hellum-filled aluminum canister containing fuel test element FTE-3 was removed from the Hallam cask and injected into the high level cell without incident. The canister was girdle-cut approximately $3 / 16$ in. deep and 30 in. from the bottom end and the piece was removed, exposing the thermocouple contacts. Thermocouple resistance readings are given in Table 8 . Comparison with preirradiation measurements shows almost no change, so it can be concluded that the operational behavior of the thermocouples was good. Pieces of the canister at the opposite end were subsequently girdle-cut and discarded until the element was entirely exposed. An this point the identity of the element was checked and the engraved identification number and the serial number photographed as shown in Figs. 7 and 8. A composite photograph of the total element is included as Fig. 9.

In order to section the fuel element, it was supported horizontally by a series of V-rollers, which facilitated horizontal and rotational movement. A special extension drill was inserted through the purge gas inlet hole in the upper reflector and a hole was drilled through the porous graphite plug. The fuel bodies were then seated against the bottom connector by using a push rod through this hole and applying force. While the bodies were held down, the upper reflector was removed by plunge-cutting through the sleeve at a point about 2 in. below the sleeve-reflector joint. The sleeve was then girdle-cut at a point about 16 in. above the sleeve-bottom connector joint. After inspecting the top surface of the graphite cloth at the upper end of the internal trap (see Fig. 10) and finding no fuel particles, the bottom section of the lower reflector was removed; 2 in. of the $\mathrm{C} / \mathrm{A}$ thermocouple cold junction was saved and stored. 
The fuel bodies were subsequently removed from the sleeve by inserting a push rod into the upper opening, holding the sleeve, and applying a force. Each individual fuel body was carefully examined externally and the graphite integrity was assessed. Composite photographs of each of the three fuel bodies are shown in Figs. 11, 12, and 13. Following visual inspection, the fuel bodies were placed in a special holding fixture to facilitate the removal of the center samples. A hole was drilled through the bottom sample hold plug and a push rod was inserted. When the upper sample hole plug was unscrewed, the distances from the top of the spine samples to the edges of the holes were measured. These measurements are compared with the preirradiation measurements in Table 9. Changes are in the range to be expected for Great Lakes Carbon Company graphite $\mathrm{H}-327$ as used for the fuel bodies (the sleeve material was the standard Core 2 graphite $\mathrm{H}-381$ ) except for the spine stack in body 1, which indicates an increase in length. However, this can be related to stack perturbance (e.g., a small chip between two spine samples could have caused this effect). The spine samples were pushed out one at a time, identified, and placed in labeled, glass sample bottles. All operations were carried out over a special pan placed to catch any loose fuel particles from the drilled hole. However, none were found. No problems were encountered during the removal or identification of the spine samples. The spine samples are described in Table 10.

Upon discharge of the spine samples, the graphite plugs capping the fuel holes were easily removed, and the distances from the top of the fuel rods to the edge of the fuel holes were measured. These measurements are compared with preirradiation measurements in Table 11. The overall results are discussed in Section 3 together with gamma scanning of the fuel stack heights. A further analysis of each of the four different fuel rod types is discussed in Section 4.4.3.

Holes were drilled on the bottom of the fuel bodies to enable the fuel rods to be pushed out with very low pushing force using a 1/8-in.-diameter push rod. All fuel rods were in excellent condition and showed no damage from the disassembly operation. After all fuel rods had been removed, the fuel bodies were sectioned as shown in Fig. 14. The graphite slices were 
used for autoradiography. Residual stress examinations may be carried out on some of the graphite bodies. Some development work in this area is still necessary and the results will be reported at a later date.

\subsection{FUEL ELEMENT SLEEVE EXAMINATION}

Photographs of the entire length of the element were taken prior to examination of the element exterior with short-focus binoculars and the in-cell Kollmorgen (see composite photograph in Fig. 9). No cracks or abnormalities were found. The overall length of the element and the sleeve diameters at various intervals were measured and recorded in Table 12 . The overall length was determined with a steel rule and confirmed by traversing its length with the saw head whose horizontal movement can be determined within $\pm 1 / 32$ in. The length change of $+0.06 \%$ is contradictory to experience, which is shrinkage for this low dose range. Therefore, the accuracy of this figure may be questioned. It is also possible that this increase was caused by handling effects.

Sleeve outside diameters were determined with calibrated snap-on dial indicator gauges; inside diameters were measured in the hot cell hood after removal of the fuel bodies. Accuracy of postirradiation diameter measurements was $\pm 0.001 \mathrm{in.;}$ the measurements were partly recorded with an arbitrary fourth digit. For the preirradiation dimensions, only manufacturing tolerances are available that are two and five times larger. Measured effects were small against these tolerances. The radial dimensional change for H-381 graphite as used for the sleeve is about $+0.05 \%$ for this low dose and temperature range (Ref. 16), which is within the systematical error bracket of the results in Table 12 .

\subsection{FUEL BODY EXAMINATION}

\subsubsection{Graphite Integrity and Dimensional Changes}

After the fuel bodies were removed from the graphite sleeve, each was placed on a granite surface plate and examined. Essentially no bowling was 
evident. Each body was photographed and visually inspected at high magnification as shown in Figs. 11, 12, and 13. No cracks or abnormalities were found. Tables 13, 14, and 15 present data on the fuel bodies.

Measurements indicated a weight increase occurred during irradiation. Recalibration of the balance in the Hot Cell revealed an error of $15 \mathrm{~g}$. Therefore no significant weight changes can be concluded because of inaccurate data. In addition, the postirradiation measurement on body No. 2 was $314 \mathrm{~g}$ above the preirradiation value which could only be caused by an error in recording. Significant weight changes, such as might be caused by corrosion effects, are not expected in the relatively clean Peach Bottom atmosphere.

Dimensional changes for longitudinal and transverse directions of the fuel bodies are shown in Tables 13, 14, and 15. The following average values were determined:

\begin{tabular}{l|c|c|c|c}
\hline & \multicolumn{5}{|c}{ Average Dimensional Changes (\%) } \\
& $\begin{array}{c}\text { Length } \\
( \pm 0.003)\end{array}$ & $\begin{array}{c}0 . \mathrm{D} . \\
( \pm 0.04)(\mathrm{a})\end{array}$ & $\begin{array}{c}\text { I.D. } \\
( \pm 0.09)\end{array}$ & $\begin{array}{c}\text { Fuel Holes } \\
( \pm 0.20)\end{array}$ \\
\hline Top body 3 & -0.06 & 0 & -0.06 & +0.21 \\
Center body 2 & -0.08 & +0.01 & -0.06 & +0.18 \\
Bottom body 1 & -0.03 & -0.02 & -0.08 & +0.02 \\
\hline
\end{tabular}

(a) Systematic error.

All changes were so small they are insignificant. For all three types of diameter measurements, the error bracket is larger than the measured effect; consequently, the increase in fuel hole diameter by about 1 mill $\equiv 0.2 \%$ seems to be a systematic error and not an irradiation effect. It is concluded that the graphite bodies in FTE-3 have suffered dimensional shrinkage of $<0.1 \%$ for the $\mathrm{H}-327$ graphite material at the experienced dose and temperature range, which was as expected. 
Comparing the as-measured dimensions of the sleeve and the graphite body, a radial gap can be determined (Tables 12 through 15):

\begin{tabular}{l|c|c}
\hline \multirow{2}{*}{} & \multicolumn{2}{|c}{ Radial Gap $\left(10^{-3}\right.$ in.) } \\
\cline { 2 - 3 } & BOL & EOL \\
\hline Top body 3 & 6.0 & 5.7 \\
Center body 2 & 6.4 & 5.6 \\
Bottom body 1 & 6.2 & 5.8 \\
\hline Average & 6.2 & 5.7 \\
\hline
\end{tabular}

It is concluded that the radial gap remained nearly constant during irradiation at $0.006 \mathrm{in.}$

Figure 14 shows the manner in which each of the fuel bodies was sectioned for the purpose of measuring hole diameters and providing samples for autoradiography and residual stress examination. Each slice was photographed (see Figs. 15, 16, and 17) and found to contain no internal cracks or abnormalities. Methods for determination of residual stresses are still under development and no results are available at this time.

\subsubsection{Autoradiography}

Beta-gamma autoradiography was employed to examine the fission product distributions in the graphite bodies. Two cross-sectional slices were cut from each graphite body. Each slice was lapped with sandpaper until one surface was flat and the slice was approximately 1/8-in. thick. Exposures were made by placing the specimen on Kodak type $M$ industrial film for $3 \mathrm{hr}$.

A description of the specimens examined is given in Table 16. Fig. Figures 18 through 20 show the autoradiographs obtained from the six graphite slices. Quantitative measurements of the optical density with a microdensitometer were not made; however, the degree of darkening is an indication of the amount of fission product diffusion into the graphite body that occurred during irradiation. 
S1ices taken from body 2, which received the peak fast neutron exposure at the highest irradiation temperature, revealed darkening around holes containing TRISO/BISO fuel rods $(1,2,3,4,7,8)$ while the area around holes 5 and 6 , which contained TRISO/TRISO fuel rods, was relatively free of fission product contamination. The activity of the slices taken from body 3 was relatively high as revealed by the degree of darkening of the autoradiographs. Fission product contamination from the adjacent spine samples may have contributed to the higher contamination observed in these slices since the particle failure fraction observed in the body 3 rods was not significantly different from the failure fractions in the body 1 and body 2 rods.

\subsection{FUEL ROD IRRADIATION PERFORMANCE}

\subsubsection{Sample Description}

The fuel combinations used in the outer eight fuel stacks of the FTE-3 test element are varieties that are relevant to the large HTGR fuel cycle. Four different particle blends have been included:

\begin{tabular}{ll|c|c}
\hline \multicolumn{2}{c|}{ Fissile } & Fertile & Hole \\
\hline 1. UO 2 TRISO & $\mathrm{ThO}_{2}$ BISO & $1 \& 2$ \\
2. (2.75 Th:U) $\mathrm{C}_{2}$ TRISO & $\mathrm{ThC}_{2}$ BISO & $3 \& 4$ \\
3. (2.75 Th:U) $C_{2}$ TRISO & $\mathrm{ThC}_{2}$ TRISO & $5 \& 6$ \\
4. UC 2 TRISO & $\mathrm{ThC}_{2}$ BISO & $7 \& 8$ \\
\hline
\end{tabular}

Two fuel holes in each of the three graphite bodies contained fuel rods of a particular particle combination. All fuel rods are nominally 0.490 in. in diameter and $1.94 \mathrm{in.} \mathrm{1ong.} \mathrm{The} \mathrm{rods} \mathrm{were} \mathrm{fabricated} \mathrm{by} \mathrm{the} \mathrm{hot-injection}$ process using pitch binder and natural-flake graphite filler followed by a heat treatment at $1800^{\circ} \mathrm{C}$. Both the fuel particles and fuel rods were made in production equipment using production processes and quality control techniques. The $\mathrm{UC}_{2}$ kernels used were carried over from phase 1 test 
element production, and the $\mathrm{UO}_{2}$ and $\mathrm{ThO}_{2}$ kernels were provided by Oak Ridge National Laboratory. The $(\mathrm{Th}, \mathrm{U}) \mathrm{C}_{2}$ kernels, which have a nominal $\mathrm{Th}: \mathrm{U}$ ratio of 2.75:1, were spheroidized for this phase of the test element program. Table 17 gives a summary of the coated particles used in the four different fuel rod blends.

\subsubsection{Visual Examination}

All fuel rods were removed from the three graphite bodies without difficulty and were in excellent condition. Photographs of representative fuel rods containing each type of particle combination, taken during the visual examination, are shown in Figs. 21 through 24. Al1 rods appeared to be in excellent condition with no major occurrences of particle-matrix debonding or matrix cracking observed.

\subsubsection{Fuel Rod Dimensional Changes}

After the fuel rods had been removed from the three fuel bodies, dimensional measurements were taken on 90 out of the 336 fuel rods and correlated with preirradiation measurements.

Axial measurements were done once per fuel rod, using a micrometer that had been calibrated with a reference gauge block to an accuracy of $\pm 1 / 1000$ in., which with 1.940 in. nominal length gives a systematic error of $\pm 0.05 \%$.

Radial measurements were done with a calibrated micrometer $( \pm 1 / 1000$ in.) at an arbitrary $0 \mathrm{deg}$ and $90 \mathrm{deg}$ line at three different axial positions (center and $3 / 8$ in. away from top and bottom end faces). Preirradiation measurements were done at the same axial positions with a ring-shaped air gauge using six nozzles. Air gauge measurements yield readings that are on the average $\delta=0.003$ in. smaller than those obtained by averaging two perpendicular micrometer readings. The diametral difference ranges from 0.0018 to $0.0042 \mathrm{in}$. for a $95 \%$ confidence interval. Therefore, the uncorrected dimensional change value had to be corrected by: 


$$
\frac{\Delta \mathrm{D}}{\mathrm{D}} \operatorname{corr} .=\frac{\Delta \mathrm{D}}{\mathrm{D}} * \frac{\mathrm{D}_{1}}{\mathrm{D}_{1}+\delta}-\frac{\delta}{\mathrm{D}_{1}+\delta} \text {, }
$$

which gives for a nominal $\mathrm{D}_{1}=0.490$ (in.) ,

$$
\frac{\Delta D}{D} \operatorname{corr} .=\frac{\Delta D}{D} * 0.9939-0.61 \quad[\%]
$$

Without this correction, some of the dimensional change measurements would have been positive, i.e., indicating swelling of the fuel rods, which is contradictory to experience. Air gauge measurements are reading an average between peak and valley of any surface irregularity; they are more representative for heat transfer gap determination. Dial gauge or micrometer readings are accounting only for a maximum diameter, which, however, is more representative for interaction considerations. Since the equipment and handling of air gauge measurements were too complicated in the postirradiation examination stage, mechanical measurements had to be made. The systematic error for the diameter measurements is assumed to $\pm 0.0012 / 0.490$ $\equiv 0.24 \%$.

Figures 25 through 28 show results of the dimensional changes for each of the four rod types as a function of their axial location in the active core. The single axial measurement and the mean value from the six radial measurements per fuel rod were averaged. (In some cases two fuel rods had been measured at the same axial position, but from two neighboring holes.) These averages again were smoothed by a least-square-fit-like curve in Figs. 25 through 28. Bars in these figures represent the range of the seven different measurements applied for one fuel rod; error bars $( \pm 0.05 \%$ for axial, $\pm 0.24 \%$ for radial measurements) are not indicated and must be added.

The average dimensional change for each fuel rod evaluated as discussed above is given in Table 18 together with the average irradiation temperature and the fast fluence. A rod-by-rod average is included as well as an overall anisotropy between axial and radial behavior. 
Anistropy $\mathrm{Y}$ is defined as:

$$
Y=\frac{\Delta L}{L} / \frac{\Delta D}{D}
$$

With $\mathrm{X}$ as the mean value in dimensional change, as given in Table 18, the individual changes can be calculated:

$$
\begin{aligned}
& \text { Axial: } \frac{\Delta L}{L}=\frac{2 Y}{1+Y} * X, \\
& \text { Radial: } \frac{\Delta D}{D}=\frac{2}{1+Y} * X
\end{aligned}
$$

A rod-by-rod average for the anisotropy,

$$
\bar{Y}=\frac{1}{n} \sum_{i}^{n}\left(\frac{\Delta L}{I}\right)_{i} /\left(\frac{\Delta D}{D}\right)_{i},
$$

1s given in Table 19 and is based on the actual measurements. In one case a measurement had been neglected (rod 1-2-3 from body 1 in hole 2 at position 3) which was with $Y=0.15 / 0.40=0.375$ too far out of pattern and obviously in error.

The following conclusions can be drawn for FTE-3 with about $900^{\circ} \mathrm{C}$ irradiation temperature and $0.6 \times 10^{21}$ nvt fast fluence:

1. UO 2 TRISO - ThO 2 BISO fuel rods (holes 1 and 2) have the highest shrinkage with $-2.0 \%$ and the lowest anisotropy with 1.05 ; however, it is the only blend where axial changes exceed radial changes.

2. (2.75 Th:U) $\mathrm{C}_{2}$ TRISO - ThC 2 BISO fuel rods (holes 3 and 4) achieved about $-1.3 \%$ at maximum and were nearly isotropic with 0.91 anisotropy. 
3. (2.75 Th:U)C 2 TRISO - ThC 2 TRISO fuel rods (holes 5 and 6) endured lowest shrinkage (as expected for TRISO/TRISO fuel) with $-1.1 \%$ at maximum and were nearly isotropic with 0.93 anisotropy.

4. UC 2 TRISO - ThC 2 BISO fuel rods (holes 7 and 8 ) had nearly the same dimensional changes with $-1.4 \%$ at maximum as the similar mixed carbide TRISO/BISO variant in 2; however, they were anisotropic with 0.76 anisotropy.

5. Comparison with other dimensional change measurements had been made earlier with $\gamma$-scanning (see Section 3) and fuel stack length measurements (see Table 11). Gamma scanning carries the uncertainty of smeared fuel zones; fue1 stack length changes via changes in plenum depth indicate generally less shrinkage than the fuel rod measurements. This is understandable because these measurements include the possible formation of axial gaps between the fuel rods. This can be calculated from the differences in total stack length (via plenum) and the discrete stack length; i.e., the sum of the individual fuel rod length measurements. Results are presented in Table 20 for each of the four blends.

Gap changes in radial direction are summarized in Table 21. Changes of fuel hole dimensions were neglected (Tables 13, 14, and 15) because of considerable inaccuracy.

The averaged gap change results are:

\begin{tabular}{l|r|r|r|r|r|r}
\hline & \multicolumn{2}{|c|}{ Body 1 } & \multicolumn{2}{|c|}{ Body 2 } & \multicolumn{2}{|c}{ Body 3 } \\
\cline { 2 - 7 } & BOL & EOL & BOL & EOL & BOL & EOL \\
\hline Axial gap, $10^{-3}$ in. & 8 & 12 & 9 & 20 & 8 & 15 \\
Radial gap, $10^{-3}$ in. & 4 & 6 & 4 & 8 & 4 & 7 \\
\hline
\end{tabular}

The radial gap is half the size of the axial gap. Change in radial and axial gap follows the same pattern. Gap increase is $50 \%$ in body $1,100 \%$ in body $2,80 \%$ in body 3 . 
6. It has been previously shown (for fuel rods having this type of matrix and having particles in a random, close-packed array) that irradiation-induced fuel rod dimensional changes are controlled by the coated particles (Ref. 8). Using this premise, diametral dimensional changes were calculated for rods representing each particle blend in bodies 2 and 3 using the SHRINK and FSVROD computer codes. These calculations underestimate the measured fuel rod dimensional changes shown in Figs. 25 through 28.

The model mainly based on dimensional change data of the coated particles until now had only been tested for fast fluences $>2 \mathrm{x}$ $10^{21}$ nvt. Material property changes for lower fluences are relatively uncertain, especially the dimensional growth rate

$$
\dot{\mathrm{g}}=\mathrm{d} \frac{\Delta \mathrm{L}}{\mathrm{L}} / \mathrm{d} \phi \mathrm{t}
$$

for $\lim \phi \cdot t \rightarrow 0$. Although effects are somewhat underestimated, relative results are correct as shrinkage for fuel rods containing TRISO/TRISO particle blends is calculated to be less than for the other three rod types containing TRISO/BISO fuel blends.

\subsubsection{Fission Gas Release Measurements}

Eleven rods were selected at random for fission gas release $R / B^{*}$ measurements (shown in Table 22). The $R / B$ data indicate very little change in the fuel particle integrity after 133 effective full-power days of reactor operation. The overall average of $\mathrm{R} / \mathrm{B}$ values remained below the large HTGR plant reference beginning-of-life value of $2 \times 10^{-5}$.

$* \mathrm{R} / \mathrm{B}=$ ratio of fission gas release rate to fission gas birth rate, at steady state. 
4.4.5. Metallographic Examination

Metallographic examination was performed on fuel rods 2-3-7, 2-2-7, 2-8-7, and 2-5-7, which contained each of the four representative particle blends. These fuel rods were from the center of body 2, which received the peak fast neutron exposure at the highest irradiation temperature. Photomicrographs of the fuel rod cross sections, matrix, and representative coated particles are shown in Figs. 29 through 36.

Coated particle fuel and matrix graphite in the four rods examined metallographically genera1ly looked good. In fuel rods $2-5-7,2-8-7$, and 2-3-7, which contained carbide fuel, the onset of hydrolysis of the lowexposure carbide fuel early during the examination made it possible to determine coating failure via metallography. However, no particle failure was observed in fuel rod 2-2-7, which contained oxide fuel particles.

No fuel kernel migration or other thermochemical effects were observed in either the carbide or oxide fuel particles. In both the TRISO-coated oxide and carbide fuel particles, the buffer coatings densified slightly and debonded from the IPyC coating, leaving the IPyC coating bonded to the SiC coating. The small fraction of cracks noted in the OPyC coatings in the composite photomicrographs of the fuel rod cross sections (see Figs. 29, 31, 33, and 35) was attributed to metallographic polishing since no mounting resin was present in the cracks.

The graphite matrix in each rod examined was in good condition. No matrix cracking or signs of matrix-coating interaction were observed.

\subsubsection{Electrolytic Disintegration - Acid Leaching Studies}

One of the primary objectives of the examination of FTE-3 fuel rod samples was to develop a method of disassociating irradiated fuel rod and allowing separation of the coated fuel particles from the graphite matrix without damaging particle coatings. A technique was developed in 
the Hot Cell to disassociate irradiated fuel rods electrolytically in an acid solution using the disintegration unit shown in Fig. 37. A fuel rod specimen was immersed in an "ultra leach" solution $\left(13 \mathrm{M} \mathrm{HNO}_{3}, 0.1 \mathrm{M} \mathrm{Al}\left(\mathrm{NO}_{3}\right)_{3}\right.$, and $0.1 \mathrm{M} \mathrm{HF}$ ) in the disintegration chamber shown in Fig. 38. P1atinum electrodes placed near the fuel rod specimen allowed a direct current $(0.2$ to $5.0 \mathrm{~A}$ ) at $12 \mathrm{~V}$ to be passed through the acid solution. Disintegration of the fuel rod occurred as oxidizing nitrate ions migrated from the cathode to the anode through the specimen and preferentially attacked the pitch coke in the fuel rod matrix. Exposed fuel and fission products were dissolved in the acid medium.

The gamma-ray spectrum of an aliquote of the leach solutions was counted by a Ge(Li) detector coupled with a Sigma II analyzer. The theoretical fission product inventory of each specimen was calculated using the Sigma II analyzer and the Fission Production computer code. The percent activity of the radioisotopes leached was compared with the theoretical amount of metallic fission products present in each specimen to ascertain the particle failure fractions.

The results of electrolytic disintegration - acid leach studies conducted on five fuel rods irradiated in FTE-3 are reported in Table 23. Analysis of the fission product isotopes recovered in the leach solutions indicated coated particle failure fractions were $<1.0 \%$ in all fuel rods examined. The low postirradiation fission gas release values $\left(10^{-5}\right.$ to $10^{-6}$ range) for these rods (see Table 23) also indicate negligible coated particle failure in these rods. Photomicrographs of coated fuel particles recovered from fuel rods $1-8-7$ and $1-8-8$ are shown in Figs. 39 and 40, respectively. Complete disassociation of the coated particles from the surrounding graphite matrix was achieved using the current densities and disintegration times noted in Table 23. (Temperature of the leach solution was about $200^{\circ} \mathrm{C}$ ). Metallographic examination was conducted on samples of fuel particles recovered from fuel rods $1-8-7$ and $1-8-8$ to investigate the effects of the electrolytic disintegration on the integrity of the particle OPyC coatings. Representative photomicrographs of particles recovered from these rods are 
shown in Figs. 41 and 42. No signs of OPyC degradation were observed in either sample. These results indicate irradiated fuel rods can be effectively disintegrated without damaging the coated particle.

\subsection{THERMAL STABILITY SPINE SAMPLES}

The thermal stability spine samples in the phase 1 and phase 2 Peach Bottom test elements were designed to provide comparative data on the irradiation performance of a large number of different particle batches under similar irradiation conditions. Each particle batch was irradiated in two different sample geometries to provide both high thermal gradient and nearisothermal environments.

\subsubsection{Test Configuration}

4.5.1.1. Type 1. The type 1 thermal stability samples were designed for the irradiation and comparison of the performances of different batches of particles under almost identical irradiation conditions and high thermal gradients. They consisted of cylindrical outer crucibles of H-327 graphite approximately $6 \mathrm{in.}$ long and $1.00 \mathrm{in}$. in diameter, as shown in Fig. 43, with screw-in end caps. Two grooves on the inside of each crucible accommodated thin, rectangular crucibles of HLM-85 graphite, each drilled with holes for individual particles and having a slide-on lid. The design for the latter crucibles is shown in Fig. 44. Eight of the small crucibles were stacked on top of one another inside each outer crucible, and a blended bed of TRISO fuel was packed into the remaining void space. The crucibles were thin enough so that radiography through the crucibles was possible after the particles had been loaded and the lid fit into place.

4.5.1.2. Type 2. The type 2 thermal stability samples were designed as a backup to the type 1 samples in order to irradiate and compare the performances of different particle batches under similar but relatively isothermal conditions. The design of the type 2 thermal stability crucibles is shown 
in Fig. 45. Five such crucibles, containing samples of 30 particle batches, were included in FTE-3.

\subsubsection{Visual Examination}

The type 1 thermal stability crucibles were removed from outer crucibles $K$ and $L$ (see Table 24) without difficulty. The graphite crucibles exhibited no signs of cracking or warping and the lid of each crucible was still secured in place.

The driver fuel surrounding the type 1 crucibles was examined for signs of particle failure, which would have resulted in contamination of the sample crucibles. Visual examination of the driver fuel in crucibles $\mathrm{K}$ and $L$ revealed $0 \%$ OPYC coating failure for the fissile and fertile fuel particles. Representative photographs taken during the visual examination are shown in Figs. 46 and 47.

Visual examination was performed on 11 particle batches irradiated in the type 2 configuration; the results are summarized in Table 25. No OPyC coating failure was observed in any of the samples examined. Photomicrographs showing representative sample size and condition of fissile and fertile particle samples irradiated as unbonded samples in the type 2 configuration are shown in Figs. 48 and 49.

\subsubsection{Radiography}

The type 1 crucibles listed in Table 24 were radiographed with the graphite 1id removed. Fig. 50 shows photographs of a typical contact microradiograph of a type 1 crucible containing samples from two particle batches. The contact microradiograph taken of each crucible was examined visually with an optical microscope. 
In general, no deleterious irradiation effects were observed in any of the particle samples tested in the type 1 crucibles. No coating failure or signs of heavy metal diffusion or fuel kernel migration were observed. No signs of iron diffusion or fuel kernel migration were observed in the $(\mathrm{Th}, \mathrm{U}) \mathrm{C}_{2}$ TRISO particles (Batch No. 4423-53D) in which the fuel kernels had been doped with 500 to 1000 ppm iron.

\subsubsection{Metallography}

Four type 2 thermal stability samples were examined metallographically. Representative photomicrographs of these samples are shown in Figs. 51 through 54. No irradiation-induced coating failure or other deleterious irradiation effects were observed with the exception of the $\mathrm{UO}_{2}$ TRISO particles (Fig. 54), which exhibited approximately $10 \mu \mathrm{m}$ of unidirectional fuel kernel migration. Slight buffer densification was observed; however, the OPyC coatings of the four particle samples showed little or no increase in optical anisotropy.

\subsection{METALLIC DIFFUSION SAMPLES}

The center spine position of FTE-3 contained, besides other species, two types of fission product release samples and metallic diffusion samples (see Table 10) as previously described (Ref. 11). The prime objectives of these spine samples were to provide data on the transport properties (including release sorption and diffusion) of fission product metals in the HTGR.

The purpose of the metal diffusion samples was to obtain:

1. Transport properties of selected metal fission products, in graphite and under HTGR conditions as a function of metal concentration and temperature.

2. Data on the effects of the presence of other fission product metals on the migration rate of individual metals (especially strontium). 
3. Data on the ability of certain getter materials to reduce metal migration. (Getter materials combine with fission products such as strontium to inhibit their diffusion into the reactor system.)

4. Data on the distribution of metal fission products between matrix material and graphite.

\subsubsection{Experimental Procedure}

FTE-3 contained 11 metallic diffusion samples, located in fuel element bodies 1, 2, and 3. The samples contained isotopes of barium, strontium, samarium, and cesium, or mixtures of these isotopes, in varying concentrations. Three of the mixed isotope samples also contained magnesium fluoride or sulfur in known quantities to study the effect that these potential getter materials have on fission product transport. It was anticipated that a chemical gettering effect could be recognized if the resultant metal concentrations (or the apparent diffusion coefficient) in the graphite were significantly lower than in the other (nongettered) specimens. The metallic source materials and their respective gettering agents were loaded as carbides into previously outgassed H-327 graphite crucibles using inerted glove-box techniques. The carbides were formed by sorbing the metal isotopes of interest on matrix material and converting to the carbide at $1400^{\circ} \mathrm{C}$ in a vacuum furnace. The conversion was accomplished by heating the loaded matrix material in a tantalum crucible lined with graphite foil to minimize contamination of the matrix with tantalum. The two types of matrix material, furfuryl alcohol resin coke and calcined petroleum coke, where used as shown in Table 26. Following conversion to carbide, the matrix was loaded into the annulus of the H-327 graphite crucible and sealed with a screw top 1 id. After loading, the crucibles were coated on the outside with polystyrene to protect the metals and carbides from exposure to moist air (thereby preventing hydrolysis or oxidation) prior to insertion in the reactor.

Fission product concentration profiles of $\mathrm{Cs}-134, \mathrm{Sr}-85, \mathrm{Ba}-133$, and Cu-154 were obtained from radial sections of the diffusion spine sample 
crucibles (shown in Fig. 55). The observed species were activation tracers from cesium, strontium, (enriched in Sr-84), barium (tagged with $\mathrm{Ba}-133$ ), and samarium (enriched in $\mathrm{Sm}-152$ ) as shown in Table 27. A summary of data on FTE-3 diffusion spine crucibles is given in Table 26. Both the center post and crucible wall were sectioned to obtain diffusion profiles.

After the irradiation of 133 effective full-power days and a suitable cooling period, the diffusion spine crucibles were removed from the fuel test element and sectioned, after the matrix material was removed, by turning the crucible walls and center posts on a lathe, uniformly removing a layer of graphite for each section. Samples of known weight were gamma-counted using a $\mathrm{Ge}(\mathrm{Li})$ crystal detector and a 4096-channel pulse height analyzer. Radiochemical analysis involving chemical separation was performed in some cases to determine $\mathrm{Sr}-85$ and Ba-133 concentrations. A 370 IBM modeI 165 computer was used in conjunction with program CPROFIT (concentration profile FIT) to assist in the analysis of the concentration profiles that were analyzed at North Carolina State University.

Examination of the profiles indicated that many of them were more complex than was expected from a single diffusing component that obeys Fick's law. More specifically, all of the cesium profiles showed a fast component, which did not correspond to a Fick's law transient diffusion behavior, with the crucible wall profiles being quite different from those of the center post. There was an indication of a slow component in the cesium profiles. Although this indication was not always very prominent, it corresponded to a diffusion coefficient $D$ of low magnitude $\left(D<10^{-11}\right.$ $\mathrm{cm}^{2} / \mathrm{sec}$ ) and showed little temperature dependence. On the other hand, the strontium and barium profiles were of the classical (Fick's law) type which could be fitted to the equation $C=C_{0}$ erfc $(x / 2 \sqrt{D} t)$ where $x$ is depth of penetration. The Eu-154 activity profiles were predominantly of the classical type, but showed in some cases an indication of a low magnitude "fast" component of a nature similar to that of cesium. In a few cases, a minor fast component for strontium and barium was suggested. 
A depletion effect was apparent in the graphite near the source matrix in the case of Sr-85, Ba-133, and Eu-154 profiles, and there was evidence of concentration (i.e., in cases where matrix loading was high) substantially increasing the diffusion coefficient of strontium, barium, and europium (samarium).

Both the Cs-134 and Eu-154 profiles showed in varying magnitudes a diffusion component coming from the outer wall of the diffusion spine crucibles. This was due to the production of these isotopes in the adjacent annular fuel compacts of the fuel element.

It was concluded from this profile data that, consistent with a number of other observations (Refs. 13-15), the fast component of cesium is very likely due to in-pore surface diffusion of atoms, which is accompanied by an activated diffusion and sorption process whereby atoms are fixed to sites where they have a low mobility. Time constants are such that a quasisteady state is reached in a few hours (or tens of hours) and then, assuming the adsorption rate coefficient $K^{*}$ to remain constant, a concentration profile is established whose shape does not change with time even though its magnitude continues to increase.

This postulated behavior in its simplest form corresponds to the following equations:

$$
\begin{aligned}
& D V^{2} C_{p}-K C_{p}=\frac{\partial C_{p}}{\partial t}=0 \\
& \frac{d S}{d t}=K C_{p}, \\
& S=K t C_{p}
\end{aligned}
$$

*Actually $\mathrm{K}$ may well change (decrease) as the concentration of absorbed atoms increases, but assuming $\mathrm{K}$ to be constant yields a tractable approximation which is expected to be a fairly good approximation at relatively low total concentrations. 
where

$$
\begin{aligned}
D= & \text { in-pore surface diffusion coefficient, } \mathrm{cm}^{2} / \mathrm{sec} \\
C_{p}= & \text { bulk concentration corresponding to atoms on pore surface } \\
\mathrm{K}= & \text { absorption rate coefficient, } \mathrm{sec}^{-1} \\
\mathrm{~S}= & \text { bulk concentration corresponding to absorbed atoms of } \\
& \text { negligible mobility. }
\end{aligned}
$$

The total bulk concentration due to surface (fast) diffusion is given by

$$
C_{f}=C_{p}+S
$$

or

$$
C_{f}=(1+K t) C_{p}
$$

The flux of atoms, $J$, due to in-pore diffusion is a function of position $r$; it is independent of time once the quasi-steady state is reached. With cylindrical geometry, it is given by

$$
J=-D \frac{d C}{d r}
$$

In terms of the total fast component concentration (which is determined by analysis of the experimental data) we define $D_{\text {eff }}$ so that

$$
J=-D_{\text {eff }}\left(\frac{d C_{f}}{d r}\right)
$$

Then from (19) and (20)

$$
D_{\text {eff }}=\frac{D}{1+K t} \text {, }
$$


and when $\mathrm{Kt} \gg 1$,

$$
D_{\text {eff }}=\frac{1}{(K / D) t} \text {. }
$$

In accordance with the above equations and the design of the experiment, which yields an approximately "infinite" cylinder geometry, and given a fast component constant concentration $C_{f}^{\circ}$ at the outer radius a of the center post and the inner radius $b$ of the crucible wall, the expected mathematical expressions for the concentration profiles are:

1. For the center post,

$$
c_{f}=c_{f}^{\circ} \frac{I_{o}(\theta r)}{I_{o}(\theta a)} \text {. }
$$

2. For the crucible wall,

$$
\begin{gathered}
C_{f}=c_{f}^{0} \frac{K_{o}(\theta c) I_{0}(\theta r)-I_{0}(\theta c) K_{0}(\theta r)}{K_{0}(\theta c) I_{0}(\theta b)-I_{0}(\theta c) K_{0}(\theta b)}+ \\
c_{f}^{L} \frac{I_{o}(\theta b) K_{o}(\theta r)-K_{o}(\theta b) I_{0}(\theta r)}{K_{o}(\theta c) I_{0}(\theta b)-I_{0}(\theta c) K_{0}(\theta b)},
\end{gathered}
$$

where

$$
\begin{aligned}
& \theta=\sqrt{K / D}, \\
& I_{0}(y) \text { and } K_{o}(y) \text { are hyperbolic (or modified) Bessel functions of } \\
& \quad \begin{array}{l}
\text { order } 0, \\
C_{f}^{L}= \\
\text { wall of the crucible. }
\end{array}
\end{aligned}
$$

$\mathrm{C}_{f}^{\mathrm{L}}$ is taken as constant for simplicity. Although it may be zero, it usually is finite and often quite pronounced in the case of Cs-134 and Eu-154 profiles. As mentioned above, it arises from activity produced in the fuel compacts of the test element. 
The slow (bulk diffusion) component concentration $C_{S}$ is taken as being approximately independent of the fast component, and since the period of fuel test element runs is sma1l relative to the characteristic slow diffusion time, $t_{D}\left(t_{D}=L^{2} / 4 D\right.$ where $L$ is the sample radius or thickness), diffusion equation solutions for small times are the most appropriate. For the center post, the solution with $\mathrm{C}_{\mathrm{S}}^{\mathrm{O}}=$ concentration of the slow component at $\mathrm{r}=\mathrm{a}$ is

$$
\begin{aligned}
\frac{C_{s}}{c_{s}^{0}} & =\left(\frac{a}{r}\right)^{1 / 2} \operatorname{erfc} \frac{a-r}{2 \sqrt{D t}}+\frac{(a-r)(D t a)^{1 / 2}}{4 a r^{3 / 2}} \operatorname{ierfc} \frac{a-r}{2 \sqrt{D t}} \\
& +\frac{\left(9 a^{2}-7 r^{2}-2 a r\right) D t}{32 a^{3 / 2} r^{5 / 2}} i^{2} \operatorname{erfc} \frac{a-r}{2 \sqrt{D t}}
\end{aligned}
$$

which is a good approximation provided $r / a$ is not too small (Ref. 9). In the case of the crucible wall, two approximate solutions apply:

1. For depths of penetration $(r-b)$ near the inner radius $b$ where $\mathrm{C}_{\mathrm{S}}^{\mathrm{O}}=$ concentration of the slow component at $\mathrm{r}=\mathrm{b}$,

$$
\frac{C_{s}}{C_{s}^{\circ}}=\operatorname{erfc} \frac{r-b}{2 \sqrt{D t}}
$$

2. For depths of penetration $(c-r)$ near the outer wall,

$$
\frac{C_{s}}{C_{s}^{L}}=\operatorname{erfc} \frac{c-r}{\sqrt[2]{D t}}
$$

where $C_{S}^{L}=$ concentration of the slow component at $r=c$.

Eqs. 22 and 24 were termed the center-post Bessel series and centerpost erfc series, respectively, while Eqs. 23 and 25 or 26 were termed the 
annular Bessel series and the annular erfc, respectively, and incorporated as optional functions to be chosen for curve-fitting by the CPROFIT computer program. CPROFIT employs a nonlinear least-squares fitting technique similar to that suggested by Bevington (Ref. 10). It is designed so that concentration profiles are divided into two or more regions and components are sequentially analyzed so that least-square fits are obtained with the concentration equations deemed appropriate. In some cases, only one region may be analyzed, depending on the nature of the available profile data.

In the case of analyses of fast component data of the crucible wall, iteration of Eq. 23, which yields curves of a variety of shapes that are dependent on $C_{f}^{L} / C_{f}^{\circ}$ and $\theta=\sqrt{K / D}$, may not always be successfully made particularly if a poor choice of $\theta$ or $\mathrm{C}_{\mathrm{f}}^{\mathrm{L}} / \mathrm{C}_{\mathrm{f}}^{\mathrm{O}}$ is made. Also, it was found that often a considerable portion of the profile curve was proportional to $\exp (-\phi r)$, which corresponds to a straight line when $\log C$ is plotted against $r$. A fit of the slope of this line then yields a tentative value for $\theta$. Accordingly an option was incorporated in CPROFIT whereby a linear least-squares fit of the straight-line portion of a semi-log concentration profile plot could be made in a region where the fast component would appear to predominate. The $\theta$ thus obtained can be then used as a starting point for an iteration involving Eq. 23, or it can be used directly to calculate an approximate value of $\mathrm{K} / \mathrm{D}=\theta^{2}$.

The result of the computer analysis of the fast (quasi-steady state) component of Cs-134 is given in Table 28. The qualities $K / D$ and $C_{f}^{O}$ (the extrapolated concentration of the fast component $r=a$ or $r=b$, the boundary adjacent to the source matrix) are obtained from computer analysis. Often more computer analysis runs than one were made with different selected breakpoints or initial values of $\mathrm{K} / \mathrm{D}$. The values from the run that appeared to give the best fit of the concentration profile plots given in Figs. 56 through 70 are given in Table 28. Figs. 56b, 57b, 62b, 63b, $64 \mathrm{~b}, 66 \mathrm{~b}, 67 \mathrm{~b}$, and $70 \mathrm{~b}$ show the fits obtained by CPROFIT for Cs-134 data. The calculated fit points are given as triangles and squares. Usually, in the case of crucible wall data, an initial linear least squares run was made, as mentioned above, to obtain an approximate value of $K / D$. The value 
of $\mathrm{D}_{\text {eff }}$ was calculated using Eq. 21'. The distribution or partition coefficient $C_{m} / C_{f}^{O}, \phi_{f}$, where $C_{m}$ is the concentration of the isotope in the matrix, is given in Table 28. It appears to be strongly temperaturedependent and tends to decrease substantially with increasing temperature. The quantity $D_{\text {eff }}\left(C_{f}^{O} / C_{m}\right)$, which is directly related to the flux of cesium by surface diffusion, is by theory independent of time (period of the FTE irradiation). This is of practical value for release calculations and corresponds to a permeability coefficient. Accordingly, we define the permeability coefficient,

$$
\mathrm{K}_{\mathrm{m}}=\mathrm{D}_{\mathrm{eff}}\left(\mathrm{C}_{\mathrm{f}}^{\mathrm{O}} / \mathrm{C}_{\mathrm{m}}\right)
$$

Moreover, the maximum, steady-state flux of cesium that will penetrate a graphite septum of thickness $L$ by the fast process is given by

$$
\mathrm{J}_{\max }=\mathrm{K}_{\mathrm{m}} \frac{\mathrm{C}_{\mathrm{m}}}{\mathrm{L}} \text {, }
$$

which is in accordance with the quasi-state theory postulated above.

Note that the Cs-134 crucible wall profiles of diffusion samples 11 , 16, and 24 (Figs. 58, 59, and 61 respectively) indicate the diffusion of Cs-134 from the outside into the annular source matrix, which in these cases originally contained no cesium. In crucible 16, nearly equilibrium concentrations of Cs-134 were apparently attained in the matrix and center post. Thus, the crucible 16 center post Cs -134 profile (Fig, 60) indicates this portion of the crucible to be loaded to about the same concentration as the inner boundary of the crucible wall. This concentration $\left(C_{f}^{\circ}\right)$ equals about $5 \times 10^{-6} \mathrm{mg} \mathrm{Cs}-134 / \mathrm{g}$, and with the matrix concentration given as $4.0 \times 10^{-3} \mathrm{mg} \mathrm{Cs}-234 / \mathrm{g}$, the distribution coefficient $\phi_{\mathrm{f}}=\mathrm{C}_{\mathrm{m}} / \mathrm{C}_{\mathrm{f}}^{\circ}=800$. Taking the matrix to comprise $0.68 \mathrm{~g}$ of material per $\mathrm{cm}$ (along the axis) and a 133 EFPD run time, an average $\bar{J}_{C s}=5.0 \times 10^{-11} \mathrm{mg}$. Cs $-134 / \mathrm{cm}^{2}$ sec is obtained. A $D_{\text {eff }}$ of approximately $8 \times 10^{-8} \mathrm{~cm}^{2} / \mathrm{sec}$ is estimated from this 
and

$$
K_{m}=D_{\text {eff }} \frac{C_{f}^{O}}{C_{m}}=1.0 \times 10^{-10} \mathrm{~cm}^{2} / \mathrm{sec} .
$$

This value of $K_{m}$ and the values of $K_{m}$ obtained from concentration profile analysis are plotted versus $10^{4} / \mathrm{T}\left({ }^{\circ} \mathrm{K}\right)$ in $\mathrm{Fig} .71$. It is seen that there is fairly good agreement at $10^{4} / \mathrm{T}\left({ }^{\circ} \mathrm{K}\right) \approx 80$ between the one $\mathrm{K}_{\mathrm{m}}$ obtained from an average flux $\bar{J}_{\mathrm{Cs}}$ and the three $\mathrm{K}_{\mathrm{m}}$ values obtained from concentration profile analysis. The permeation coefficient $\mathrm{K}_{\mathrm{m}}$ appears to be strongly temperature-dependent with $Q \approx 59 \mathrm{kcal} / \mathrm{mole}$. Note that the high $\mathrm{K}_{\mathrm{m}}$ values obtained from the analysis of center-post profiles of samples 63 and 66 occurred for the two instances where less strongly Cs sorbing (lower $\phi_{f}$ ) calcined petroleum coke (with $0.5 \% \mathrm{~S}$ content) was used as the matrix instead of the furfuryl alcohol coke used in the other diffusion crucibles. The line on the graph (Fig. 71) corresponds approximately to the equation $\log _{10} \mathrm{~K}_{\mathrm{m}}=2.9-1.40\left(10^{4} / \mathrm{T}\right)$.

The results of the computer analysis of the slow (bulk diffusion) component of cesium is given in Table 29. $\mathrm{C}_{\mathrm{m}} / \mathrm{C}_{\mathrm{s}}^{\mathrm{O}}$ ( $\phi_{\mathrm{s}}$ for slow component) and $\mathrm{D}$ obtained by fitting the data to Eq. 24 or Eq. 25 as appropriate, are given. Note that $D$ is quite small $\left(<10^{-11} \mathrm{~cm}^{2} / \mathrm{sec}\right)$ and displays little or no temperature dependence. Whether this $\mathrm{D}$ truly represents a diffusion process is questionable.

The results of the computer non-linear least-squares fitting of concentration profiles of $\mathrm{Sr}-85, \mathrm{Eu}-154$, and $\mathrm{Ba}-133$, respectively, are given in Tables 30,31 , and 32 . The concentration profile plots shown in Figs. 72 through 98 were primarily of the classical (transient Fick's law) type, and there was little difference between center-post and crucible-wall profiles. Figs. $73 \mathrm{~b}, 74 \mathrm{~b}, 87 \mathrm{~b}, 88 \mathrm{~b}$, and $89 \mathrm{~b}$ show the fits obtained by CPROFIT for $\mathrm{Sr}-85, \mathrm{Eu}-154$, and Ba-133. The calculated fit points are given by triangles. Some of the profiles show a turning down of "depletion" effect for points near the boundaries $r=a$ or $r=b$. This is tentatively 
explained as due to a "back-diffusion" of isotope into the source matrix when the test fuel element temperature decreased as the experiment progressed. Figure 5, which gives the temperature history of FTE-3, indicates that fuel element temperature decreased with time.

The diffusion coefficients (D) given in Tables 30,31 , and 32 , are plotted as $\log \mathrm{D}$ vs $10^{4} / \mathrm{T}\left({ }^{\circ} \mathrm{K}\right)$ in Fig. 99. Presently used reference diffusion coefficients for $\mathrm{Sr}(\mathrm{Eu}), \mathrm{Ba}(\mathrm{Sm})$, and $\mathrm{Ce}$ are also indicated. The diffusion coefficients of the three isotopes are seen to be similar and show a strong temperature dependence. Note that all the diffusion coefficients of the crucible-55 run data are high. The crucible-55 source matrix had an unusually high source loading (see Table 27) and thus a high $\mathrm{C}_{\mathrm{m}}$. Thus the effect of concentration on increasing diffusion rates appears to be positively indicated. Also note the high matrix loading and $\mathrm{C}_{\mathrm{m}}$ of strontium, which appears to be reflected in high diffusion coefficients for sample 42 . Another interesting observation is that the values of $\mathrm{C}_{\mathrm{s}}^{\mathrm{O}}$ for sample 55 are not larger than other values. The $\phi$ value for sample 55 (containing $1 \% \mathrm{MgF}_{2}$ ) was nearly two orders of magnitude larger than for the other samples analyzed, as shown in Table 30. Thus it would appear that an additive such as $\mathrm{MgF}_{2}$ might very well inhibit strontium migration. The isotopes of barium, cesium, and europium, on the other hand, exhibit essentially no effect when small amounts of $\mathrm{MgF}_{2}$ are added to the matrix.

A wealth of observations has resulted from a systematic computer analysis of the FTE- 3 metallic diffusion sample profiles. Cesium behaved very differently from strontium, europium, and barium and it appears the most significant features of the Cs-134 profiles are due to a surface (fast) diffusion, quasi-steady state process. For simplicity and to avoid a detailed mode1, the Cs atoms that arrive by surface diffusion at a given point are assumed to undergo sorption (with perhaps some diffusion) to become more or less immobile. A model such as that of grain boundary diffusion (somewhat analogous to that occurring in metals) is not ruled out. The grain boundary model might be termed a slowly varying quasi-steadystate model. The data on the diffusion of $\mathrm{Sr}, \mathrm{Eu}$ ( $\mathrm{Sm}$ ), and $\mathrm{Ba}$ lead to no greater surprises and, in general, tend to agree with the magnitude of 
previously determined bulk diffusion coefficients. The observation of the effect of concentration on diffusion deserves a more quantitative study when and if more data are available for consideration. Also the phenomenon of "depletion" or "back-diffusion" observed in some of the Sr-85, Eu-154, and $\mathrm{Ba}-133$ profiles should be considered further. The addition of $\mathrm{MgF}_{2}$ to the matrix material also deserves additional study when more data becomes available.

\subsection{FUEL PARTICLE FISSION PRODUCT RELEASE SAMPLES}

FTE-3 contained 18 fuel particle samples located in spine bodies 1, 2, and 3. The purpose of these samples was to provide irradiated fuel particles for a variety of long and short term chemistry experiments, the objectives of which are to provide information on:

1. In-pile and out-of-pile fission product release rates for BISO and TRISO fuel particles as a function of burnup and temperature.

2. Fission product release from fuel kernels as a function of burnup and temperature.

3. The effect of different types of kernels (fissile, fertile, oxides, and carbides) on fission product release.

4. The effect of metal doping of the coatings on fission product release.

5. The distribution or partition coefficients for metallic fission products of interest.

\subsubsection{Experimental Procedure}

The fission product release samples were composed of loose fuel particles contained in a small inner graphite crucible surrounded by matrix material inside an outer graphite (type 1, Fig. 100) or niobium (type 2, 
Fig. 101) crucible. Tbe inner graphite crucibles were made from $\mathrm{H}-237$ graphite and the matrix graphite for retaining released fission product metals was CPC type coke. Five hundred selected particles were first X-radiographed and then loaded into each crucible. The type 2 niobium crucibles were electron-beam-welded shut for complete containment of all fission products. The type 1 graphite crucibles were designed to allow diffusional release of the more volatile metallic fission products.

4.7.1.1. Type 1 crucible. The fuel particles used in the type 1 graphite crucible samples are shown in Fig. 100. They are described in Table 33. The gross fission product distribution of the various particle batches was first determined by gamma counting the component parts of each specimen. The inner and outer graphite crucibles were then sectioned on a lathe to determine concentration profiles through the crucible wall. A knowledge of the fission-product concentration between the inner crucible wall matrix and outer crucible wall matrix results in a distribution or partition coefficient $(\phi)$ that is a necessary input to the FIPER code for calculating fission product release in HTGR systems. Table 34 shows the Cs-134 and Cs-137 partition coefficients obtained from the ratio of matrix to matrixcrucible interface concentration for both the inner and outer crucibles. The $\phi$ values are all relatively low, certainly comparable to the $\phi$ values derived from the metallic diffusion samples (see Table 26 for crucible 63 and 66 data). The low $\phi$ values are consistent with the relatively low values found for the metallic diffusion samples, in the case where they had a CPC matrix (i.e., crucibles 63 and 66 as indicated in Table 26).

4.7.1.2. Type 2 crucible. Four type 2 niobium-canned fission product release samples (Nos. $\mathrm{Nb}-3, \mathrm{Nb}-6, \mathrm{Nb}-10$, and $\mathrm{Nb}-14$ ) were irradiated in FTE-3. The purpose of the niobium can was to retain the fission products released during irradiation. Table 35 describes the fuel particles used in the four samples. The crucible arrangement (Fig. 101) included graphoil and niobium foil wrapped around the inner graphite crucible prior to sealing in the niobium crucible. The foil was used as a spacer between inner and outer crucibles. 
A thermal analysis of the fission product release samples was performed to determine the maximum fuel particle bed temperature (BOL). Temperature data are shown in Table 36, where a maximum fuel particle bed temperature of $1371^{\circ} \mathrm{C}$ is indicated. The increase in temperature from the $1100^{\circ} \mathrm{C}$ spine temperature consists of a $90^{\circ} \mathrm{C}$ rise across the helium gap, an $80^{\circ} \mathrm{C}$ rise across the foil-filled gap between the niobium and graphite crucibles, and a $100^{\circ} \mathrm{C}$ rise from the graphite crucible into the fuel particle bed. On the basis of this analysis, the fuel bed temperature is taken to be $1360^{\circ} \mathrm{C}$.

The TAC2D computer code was used for the thermal analysis. The thermal mode1, which was based on drawings from Ref. 11, incorporated a fuel particle bed 0.025 in. deep. Equal spacing was assumed between the graphoil and niobium sheets that surround the inner graphite crucible on the sides and top. The spacing between foils located below the graphite crucible was taken as $0.005 \mathrm{in.}$ These spaces were filled with an unknown mixture of argon, nitrogen, and methane gas; however, for the present analysis, a gas with the thermal conductivity of nitrogen was assumed.

The 0.1-in. nominal radial gap existing between the niobium crucible and the $1100^{\circ} \mathrm{C}$ outer body was assumed to be filled with helium.

The primary uncertainties in the analysis are (1) the composition (and thus the thermal conductivity) of the gas in the particle bed and in the space between crucibles, and (2) the spacing of the foils beneath the graphite crucible. Since the graphite crucible exerts a relatively small pressure on the foils beneath it, the gaps between the foils may be larger than the 0.005 in. assumed, but are probably not smaller than this value. Wider gaps would increase the fuel temperature.

In order to establish the probable temperature limits within which the fuel was likely to have operated, runs were made with argon gas (low thermal conductivity) and methane gas (high thermal conductivity) in the gap. Maximum fuel temperatures of $1395^{\circ} \mathrm{C}$ with the argon and $1326^{\circ} \mathrm{C}$ with the methane were obtained, in comparison with $1371^{\circ} \mathrm{C}$ obtained with nitrogen. 
After irradiation in FTE-3, the four fission product release samples were separated into component parts and gamma-counted to determine the distribution of $\mathrm{Cs}-137, \mathrm{Ce}-144$, and $\mathrm{Zr}-95$. The particles were separated from the coke material by screening. The fission product distribution data are given in Table 37.

As shown in Table 37, the retention of $\mathrm{Cs}-137$ in the $\mathrm{Nb}-3$ BISO particles was relatively high (0.94 fraction) considering the high irradiation temperature $\left(1360^{\circ} \mathrm{C}\right)$. The relatively low retention of Ce-144 ( 0.81 fraction) is consistent with experience on cerium retention. The presence of about $5 \%$ of the $\mathrm{Zr}-95$ outside the $\mathrm{Nb}-3$ particles suggests that about $5 \%$ of the particles failed and that the fuel kernels broke into fragments that became associated with other components. Zirconium is a non-volatile refractory metal, and would be expected to remain with the fuel at the irradiation temperature of $1360^{\circ} \mathrm{C}$. The releases of $\mathrm{Cs}-137$ and $\mathrm{Zr}-95$ from the $\mathrm{Nb}$ particles were similar (0.006 and 0.05 , respectively), suggesting that the fractions of $\mathrm{Cs}-137$ outside the fuel particles were more likely the result of broken particles than of release by diffusion.

As expected, the TRISO particles (sample Nb-6), in comparison with the BISO particles, were more effective in retaining the metal nuclides. Two percent of the $\mathrm{Zr}-95$ was found outside the TRISO particles, suggesting that $2 \%$ of the particles failed and broke into fragments.

The data for sample $\mathrm{Nb}-10$ indicate that silicon-doping of the BISO coating was not effective in retaining the metal nuclides. The $\mathrm{Nb}-14$ particle sample showed the highest release of $\mathrm{Cs}-137$, indicating that the particular combination of $\mathrm{UO}_{2}$ kernel and BISO coating was not effective in retaining cesium. On the other hand, the $\mathrm{Nb}-14$ particle sample showed high retention of $\mathrm{Ce}-144$, indicating the effectiveness of oxide kernels in retaining cerium. 


\section{CONCLUSION}

The postirradiation examination of the fuel element FTE-3 itself, the fuel rods, and the spine samples contributed additional information toward understanding the integral structural and fission product behavior in an HTGR reactor system.

Evaluation of the irradiation conditions for 133 EFPD of exposure in Peach Bottom Unit 1, Core 2 resulted in a fast fluence of $0.60 \times 10^{21} \mathrm{n} / \mathrm{cm}^{2}$ $(E>0.18 \mathrm{MeV})$, a thermal fluence of $0.66 \times 10^{21} \mathrm{n} / \mathrm{cm}^{2}(E<2.83 \mathrm{eV})$, an irradiation average fuel temperature of $913^{\circ} \mathrm{C}$, and a calculated burnup of 11.3\% FIMA for fissile and 0.057\% FIMA for fertile material (al1 values are peak values). Weekly thermocouple readings have been analyzed in order to achieve a representative average during the time of irradiation, resulting in $200^{\circ} \mathrm{C}$ to $300^{\circ} \mathrm{C}$ lower peak fuel temperatures than predicted. This indicates a $30 \%$ lower power level than anticipated. This discrepancy will be further analyzed by burnup measurements*.

Gamma-scanning for length determination of the fuel zones, as done at Peach Bottom, revealed less shrinkage than found during the postirradiation measurements. This can be explained by the nature of the $\gamma$-scanning, which counts smeared fuel zones instead of individual fuel stacks, of which there are eight in FTE-3.

At Hot Cell examinations, the element was found to be in excellent condition with regard to the integrity of graphite sleeve and experimental fuel bodies. Axial and radial dimensional changes were in the range of

*This will be reported in a forthcoming topical report about the postirradiation examination of FTE-4, a companion experiment to FTE-3, but of higher exposure. 
$<0.1 \%$ which is consistent with the material data of the $\mathrm{H}-381$ (sleeve) and H-327 (fuel body) graphites. A small increase in total length of the element and an increase in fuel hole diameter are attributed to inaccurate measurement methods.

Gap calculations from dimensional data gave a nearly constant duringlife gap of 0.006 in. between sleeve and graphite body. Axial gaps between fuel rods and radial gaps between fuel rods and surrounding graphite showed an increase by about $100 \%$ with BOL values of 0.008 in. and 0.004 in., respectively.

Fuel rod dimensional change data, received from 90 out of 336 hotinjected fuel rods, revealed nearly isotropic behavior for 3 out 4 blends, with oxide TRISO/BISO fuel being less isotropic than the carbide and (Th,U) mixed carbide TRISO/BISO and TRISO/TRISO fuel. Changes were highest (about $2.0 \%$ ) for the oxide TRISO/BISO fuel and lowest (about 1.1\%) for the mixedcarbide TRISO/TRISO fuel.

Attempts to verify the experimental findings with an existing computer code model, proven for fluences $>2 \cdot 10^{21}$ nvt, gave the same qualitative results, but did quantitatively underestimate the fuel rod dimensional change effect. This is related to uncertainties of material input data at this low fluence.

Visual examination of the fuel rods showed them to be in excellent condition with no major occurrences of particle-matrix debonding or matrix cracking observed. No signs of fuel kernel migration or other thermochemical effects were noted from thermal stability sample examinations. Less than $1.0 \%$ particle failure was determined for all fuel rods examined, based on metallographic examination, postirradiation fission release measurements, and electrolytic disintegration-acid leach studies. The electrolytic disintegration technique for coated fuel particle and matrix graphite separation had been developed for this purpose. 
Autoradiography on graphite slices cut from the fuel bodies revealed qualitatively less graphite contamination near fuel holes containing all TRISO fuel. No internal cracks in the graphite bodies could be found from these graphite slices either.

The postirradiation fission gas release from fuel rods containing both TRISO and BISO fuel particles remained essentially as it was prior to irradiation. This is not unexpected considering the short length of time in the reactor (133 EFPD).

An abundance of information has resulted from the analysis of metallic diffusion sample profiles. The behavior of cesium in graphite was found to be very different from strontium, europium, and barium. The cesium diffusion profiles are complex showing both a fast (surface diffusion) and slow (bulk diffusion) component. A comparison of permeability coefficients $\left(K_{m}\right)$ obtained from concentration profiles and a calculated value obtained from an average flux $\left(\bar{J}_{C s}\right)$ shows good agreement, thus giving some measure of confidence to the in-pore diffusion mechanism postulated herein.

The partition coefficients $(\phi)$, a necessary input to the FIPER code for calculating fission product release, were obtained for both the fast and slow components. They appeared to be strongly temperature-dependent, decreasing several orders of magnitude over a $300^{\circ} \mathrm{C}$ temperature increase. The mechanism for release of strontium, europium, and barium was determined to be bulk diffusion, thus showing good agreement with previously determined mechanisms. The diffusion coefficients of the three isotopes show a strong temperature dependence. In addition, there is an apparent concentration dependence although sufficient data is not available to verify this phenomenon.

The addition of a gettering material such as $\mathrm{MgF}_{2}$ has been shown to be effective in retaining strontium, while essentially no effect was observed for the release of barium, cesium, and europium. Additional experiments should be performed to verify these results. 
Fission product release samples were also sectioned to determine partition coefficients. The samples and a CPC coke filler were used as the retention matrix; they showed relatively low $\phi$ values. This is consistent, however, with the data obtained from the analysis of the diffusion samples of crucibles 63 and 66, which had a CPC matrix. The silicon-doping of BISO coatings was not effective in retaining the metallic fission products. BISO-coated particles with oxide kernels were shown to be effective in retaining cerium; however, the cesium release was higher than from carbide kerne1s. 


\section{REFERENCES}

1. Steward, K. P., "Objectives and Plans for Fuel Testing in the Peach Bottom HTGR," General Atomic Company Report Gulf-GA-10065, April 23, 1970 .

2. Vrouwes, J. H. L., and D. L. Hansen, "Thermal Analysis of Fuel Test Elements," General Atomic Company Report GA-A10911, June 15, 1974.

3. Sandefur, N. L., J. S. Steibel, and R. J. Grenda, "EMF Drift of Chromel/Alumel and $\mathrm{W}-3 \% \mathrm{Re} / \mathrm{W}-25 \% \mathrm{Re}$ Thermocouples Measured In-Pile to High Neutron Exposures," USAEC Report Gulf-GA-A12501, General Atomic Company, May 24, 1973.

4. Scheffel, W. J., et al., General Atomic Company, "Peach Bottom Report No. 2 - Annual Progress Report for the Period Ending June 30, 1972," GA-A13093, to be published.

5. Wagner, R. M., "GAUGE. A 2-Dimensional Few Group Neutron Diffusion Depletion Program for a Uniform Triangular Mesh," General Atomic Company Report GA-8307, March 1968.

6. Scheffel, W.J., et a1., General Atomic Company, "Peach Bottom 150 Ful1-Power Day Core Examinations," unpub1ished data.

7. Vrouwes, J. H. L., General Atomic Company, "Phase 2 Test Element Program, Pre-Irradiation Data Collected by Fuel Design Branch," unpublished data.

8. "Public Service Company of Colorado 330-MW(e) High-Temperature GasCooled Reactor Research and Development Report. Quarterly Progress Report for the Period Ending September 30, 1970," USAEC Report GA10313, General Atomic Company, October 30, 1970.

9. Crank, J., Mathematics of Diffusion, page 66, Oxford Press (1957).

10. Bevington, P. R., Data Reduction and Error Analysis for the Physical Sciences, McGraw-Hill (1969).

11. Steward, K. P., General Atomic Company, "Spine Samples in the Phase I and Phase II Peach Bottom Test Elements," unpublished data. 
12. Burnette, R. D., W. E. Bell, and N. L. Baldwin, "Fission Product Retention Characteristics of HTGR Fuel," Proceedings of the British Nuclear Society Conference, London, England, October 15-19, 1973.

13. Besenbruch, G. E., et al., "Diffusion Behavior of Strontium in Graphite," Trans Am Nuclear Soc. 12,81 (1969).

14. Skarker, A. L. and L. R. Zumwalt, "Fast and Slow Diffusion of Borium in Reactor Grade Graphite," Trans Am Nuclear Soc. 15, 760 (1972).

15. Chandra, D. and J. H. Norman, General Atomic Company, "Diffusion of Cesium through Graphite," GA-A13019, to be published.

16. Harmon, D. P., C. B. Scott, and W. J. Scheffe1, "Postirradiation Examination of Peach Bottom Core-2 Fuel Element C11-07," GA-A12460, to be published. 
APPENDIX A

FIGURES

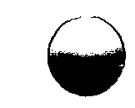




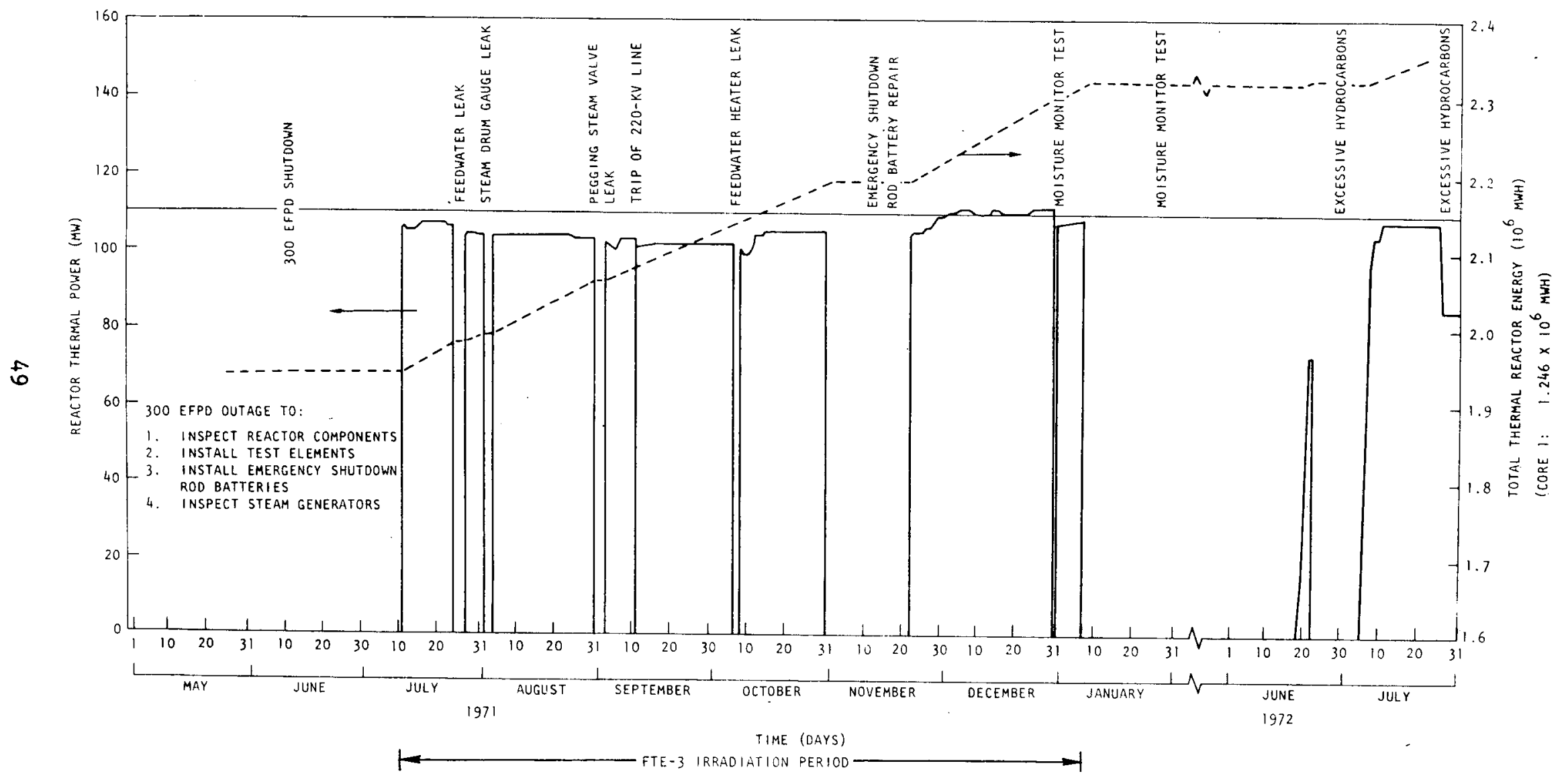

Fig. 1. Peach Bottom Unit 1 reactor history 


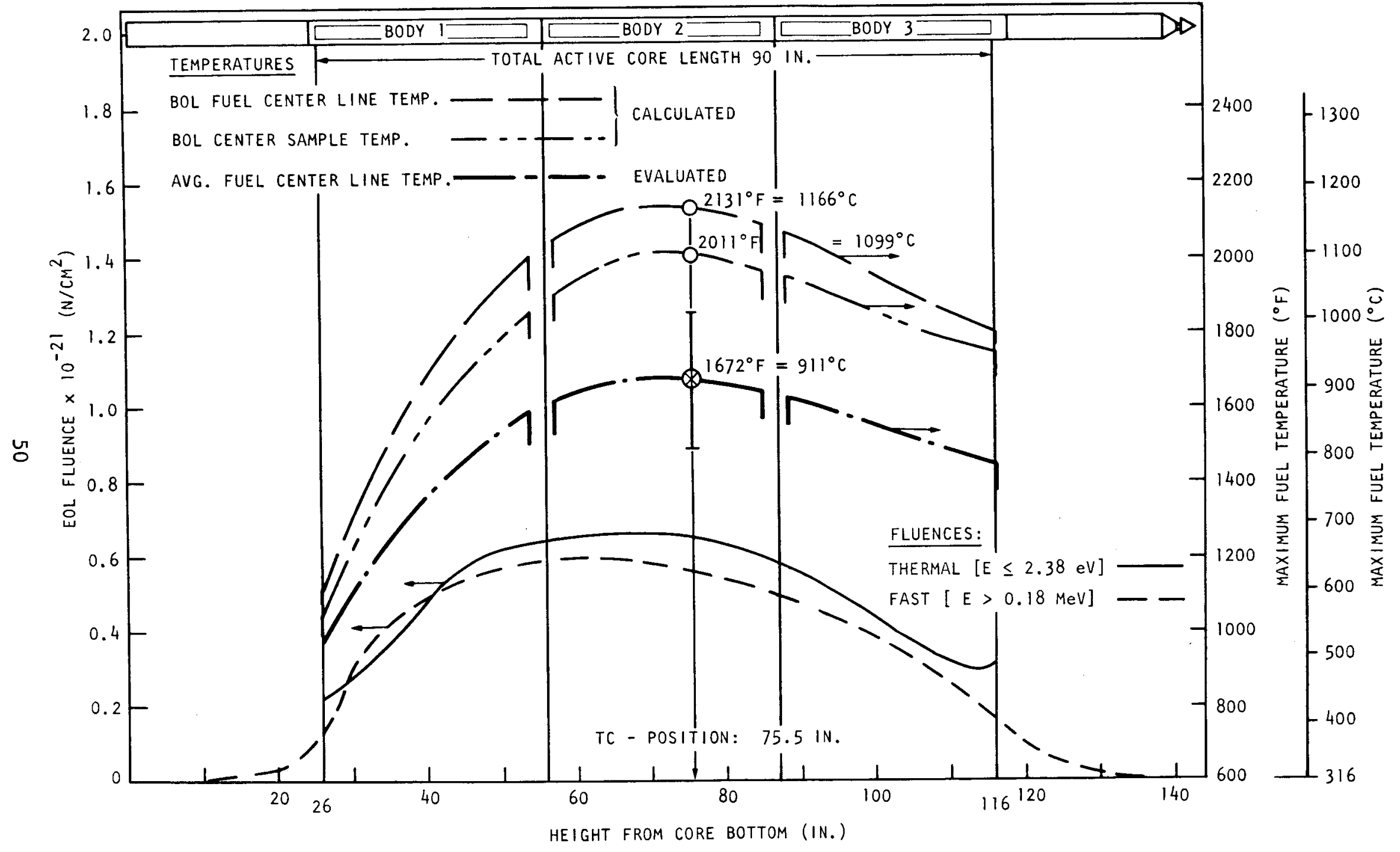

Fig. 2. FTE-3 calculated temperature and fluence profiles, evaluated average during life temperature profile 


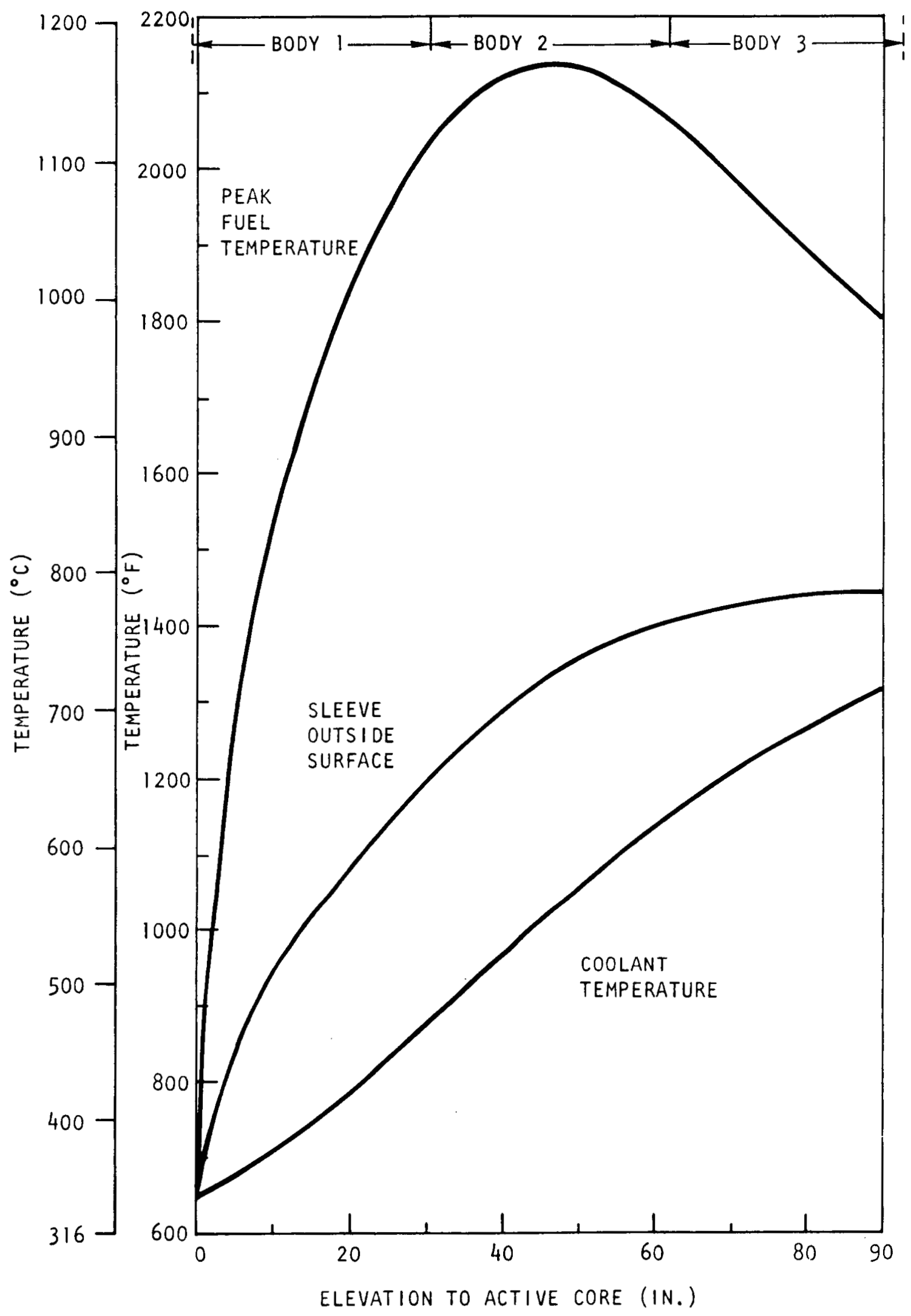

Fig. 3. FTE-3 calculated fuel centerline, sleeve outside surface and coolant temperature (BOL) 


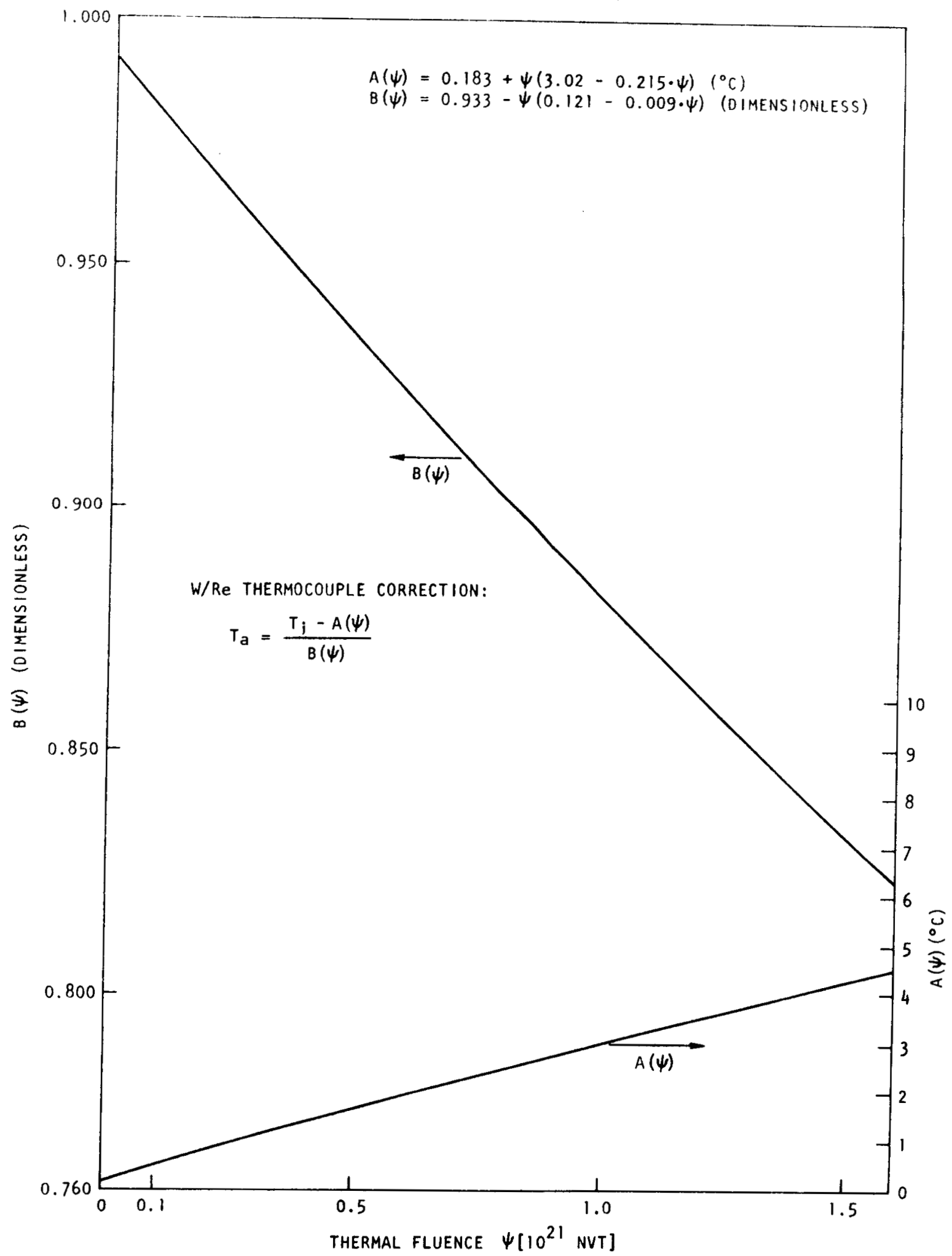

Fig. 4. Correction terms for W/Re thermocouple permutation 


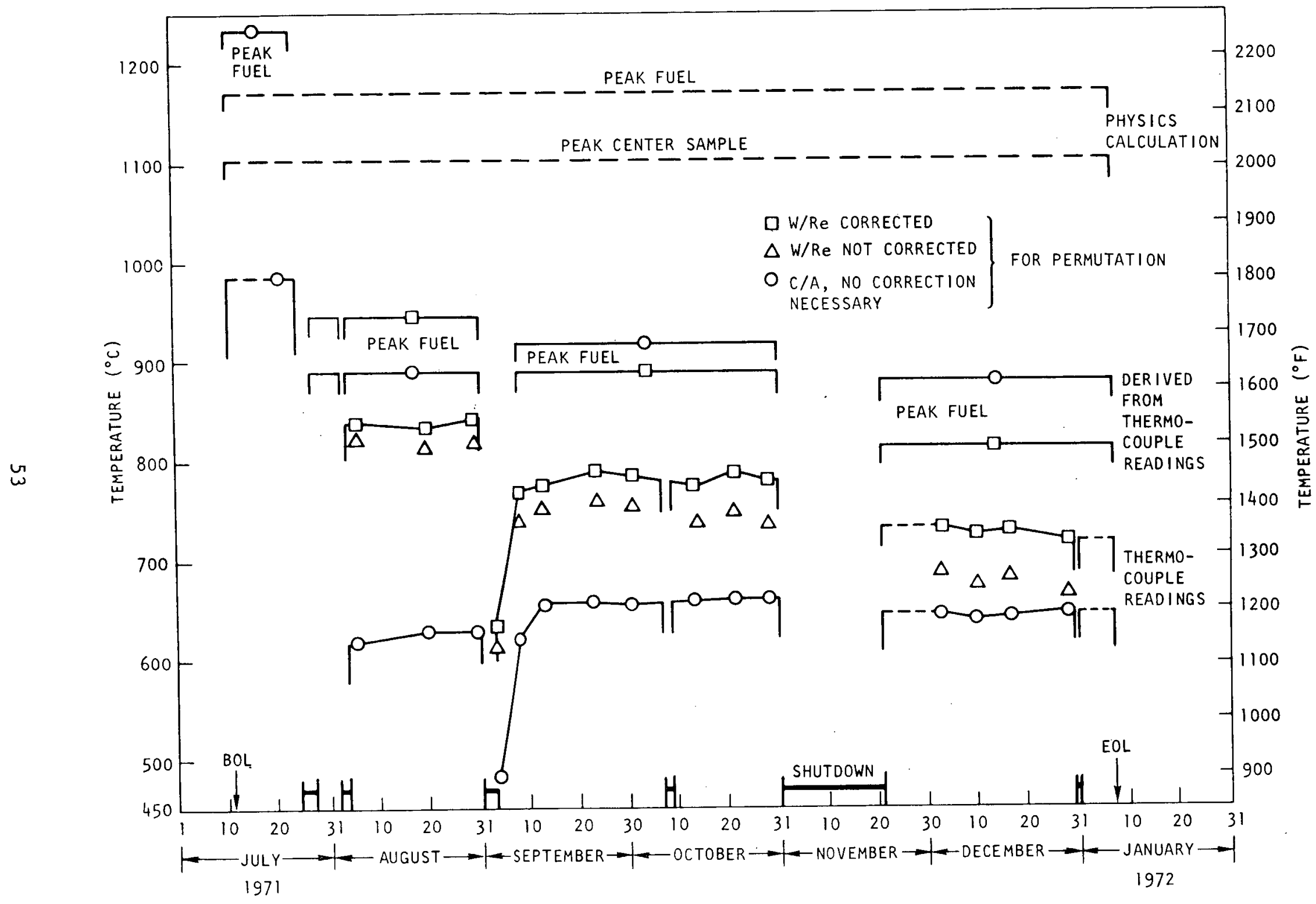

Fig. 5. Temperature history from thermocouple readings fof FTE-3 


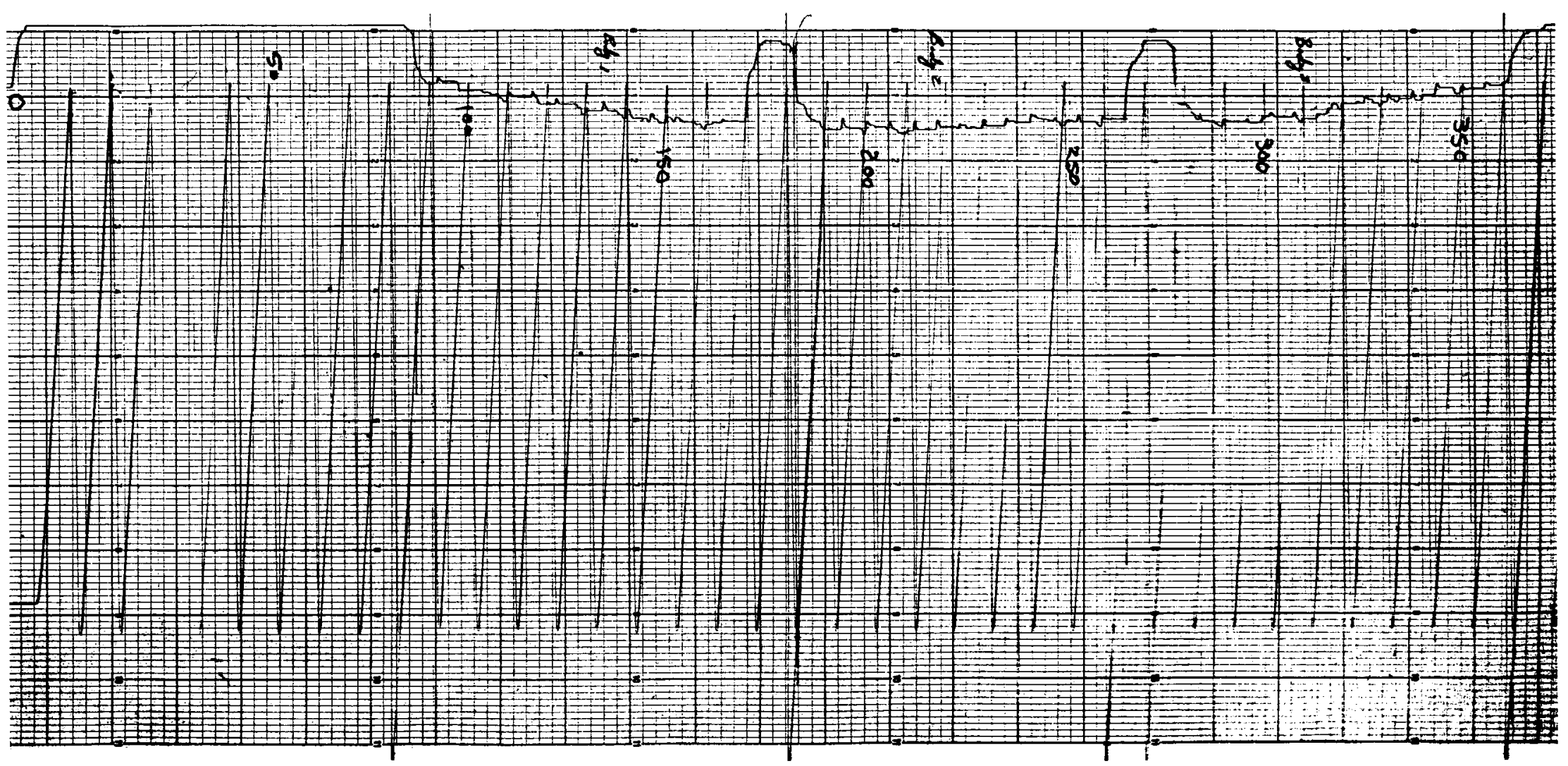

Fig. 6. FTE-3 gamma scan trace

O 


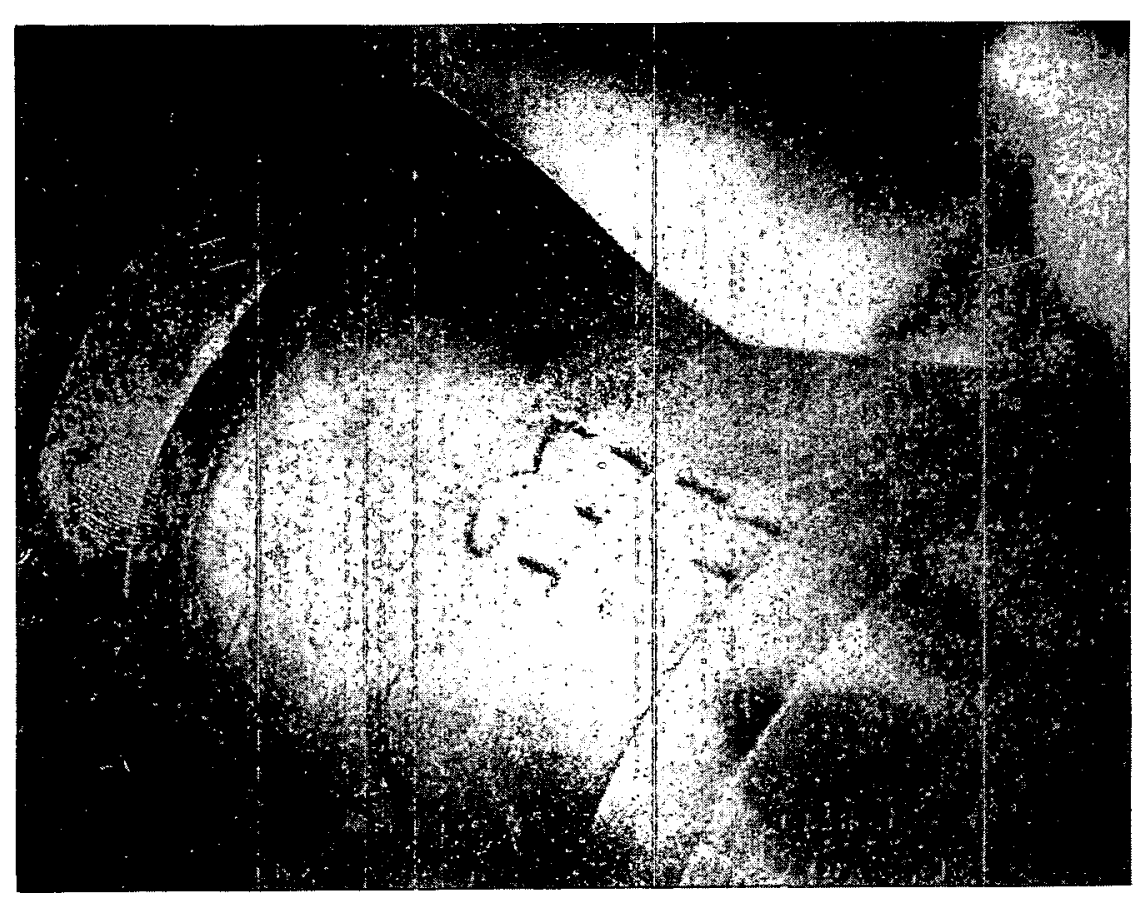

K7311-1

Fig. 7. Fuel element identification FTE-3 (mirror image)

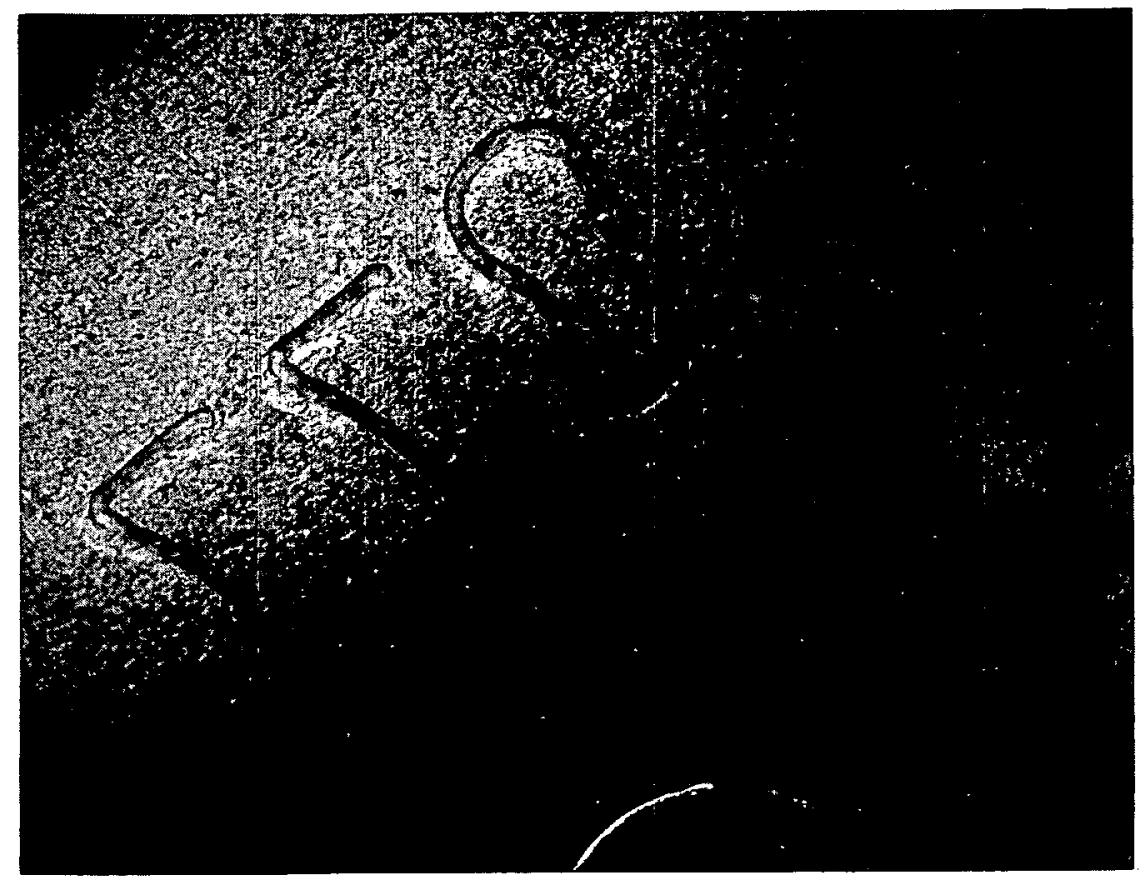

K7311-2

Fig. 8. FTE-3 fuel element serial number 877 (mirror image) 
$$
\text { . }
$$ 

$\dot{0}$

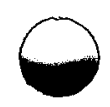




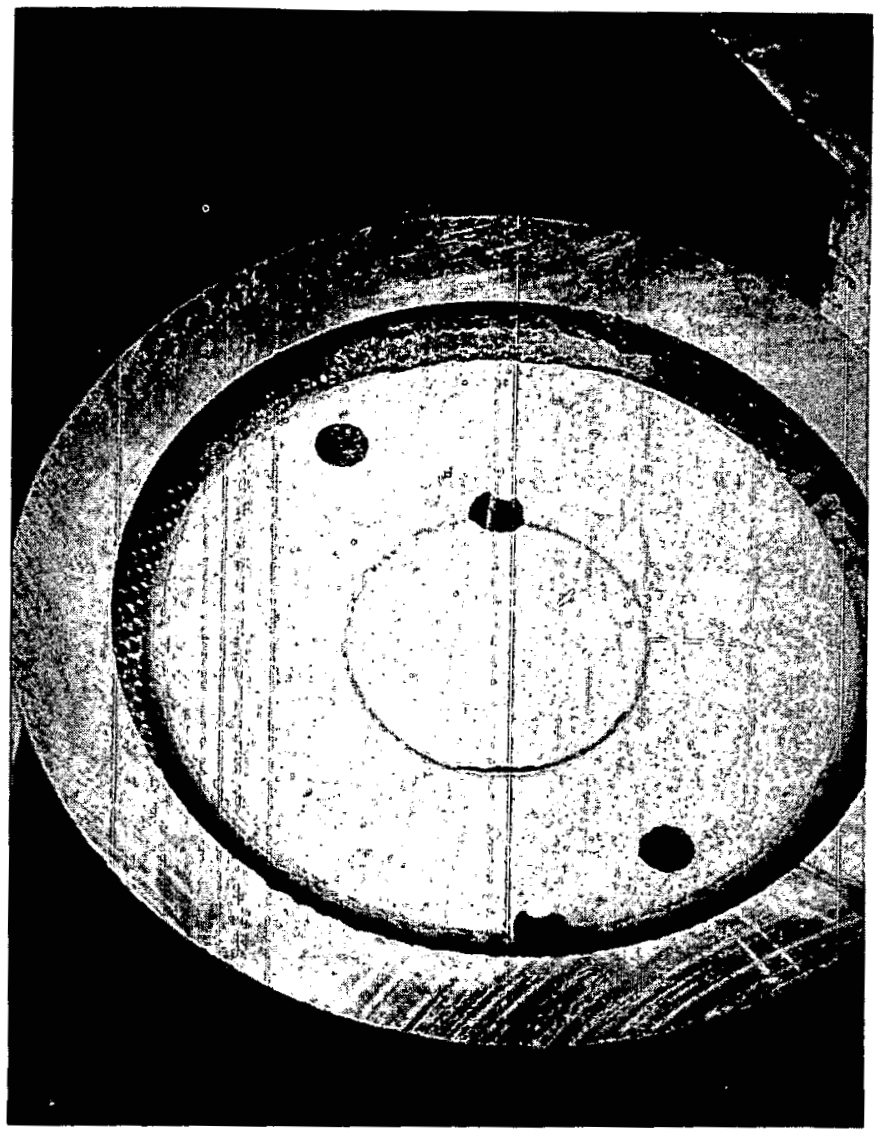

K7311-13

Fig. 10. FTE-3 internal trap, upper end view (mirror image) 


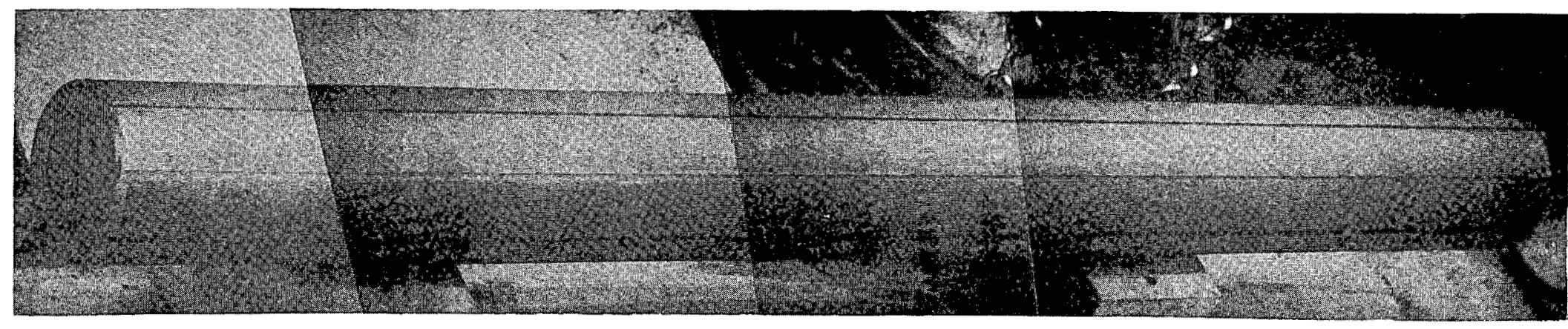

Fig. 11. Bottom fuel body (1) from FTE-3 (mirror image) 


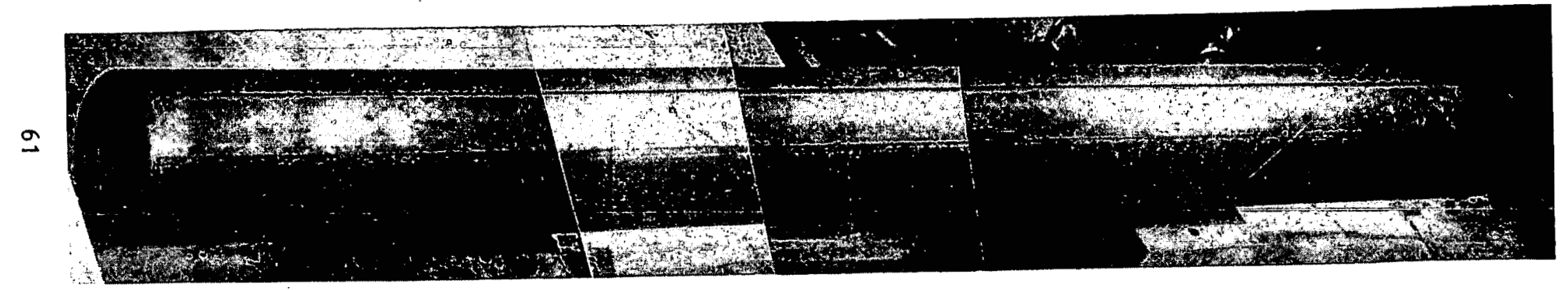

Fig. 12. Center fuel body (2) from FTE-3 (mirror image) 


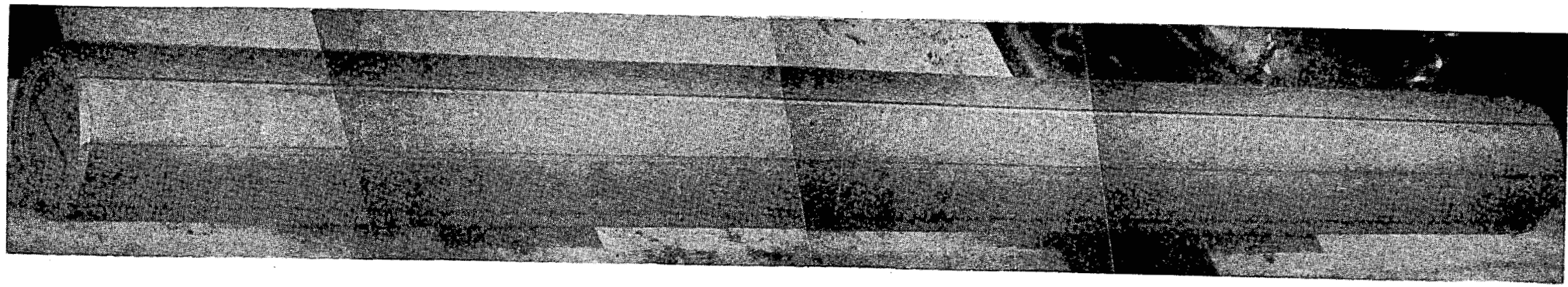

Fig. 13. Top fuel body (3) from FTE-3 (mirror image) 

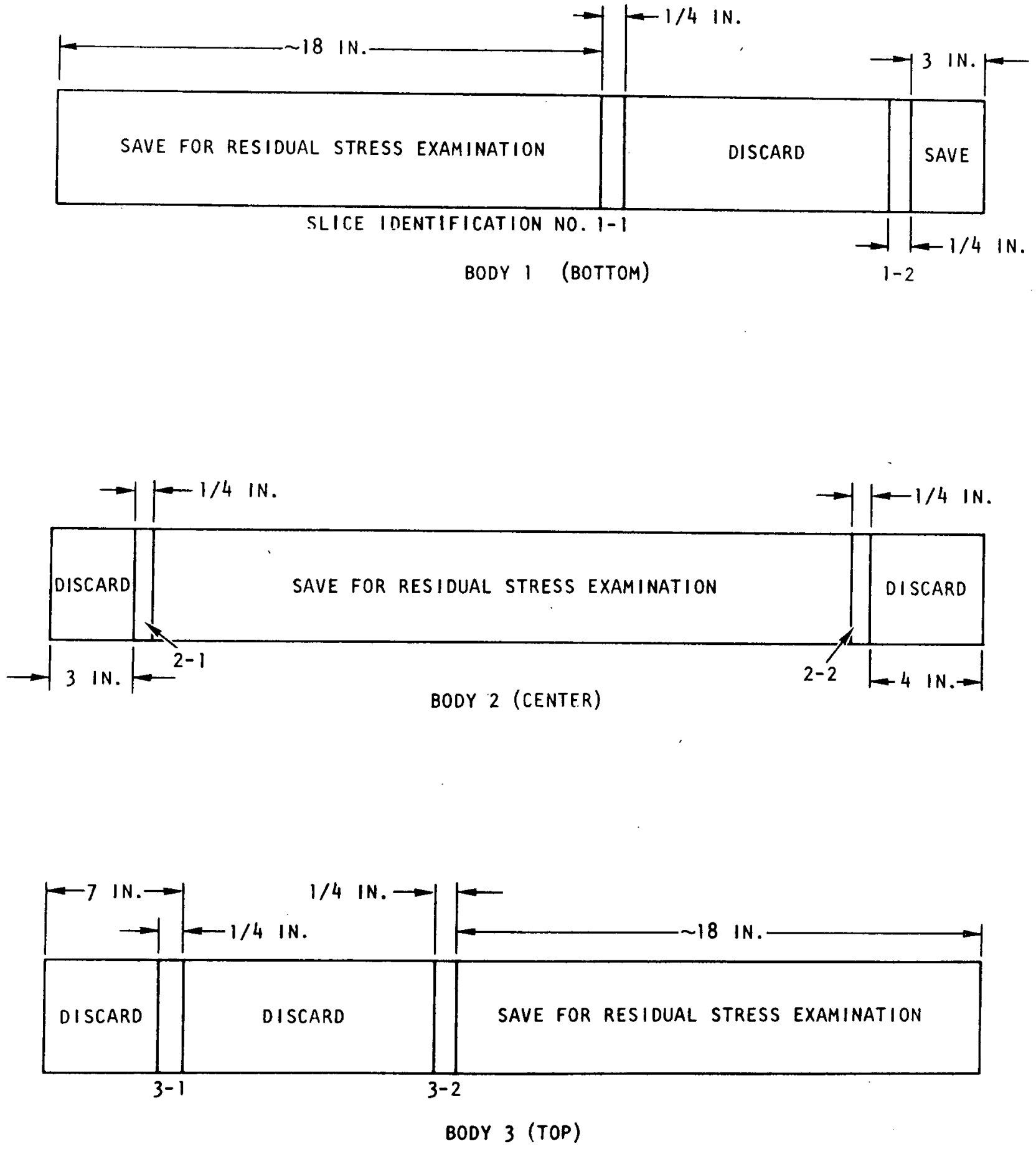

Fig. 14. FTE-3 graphite body sampling plan for inside diameter measurements and autoradiography 


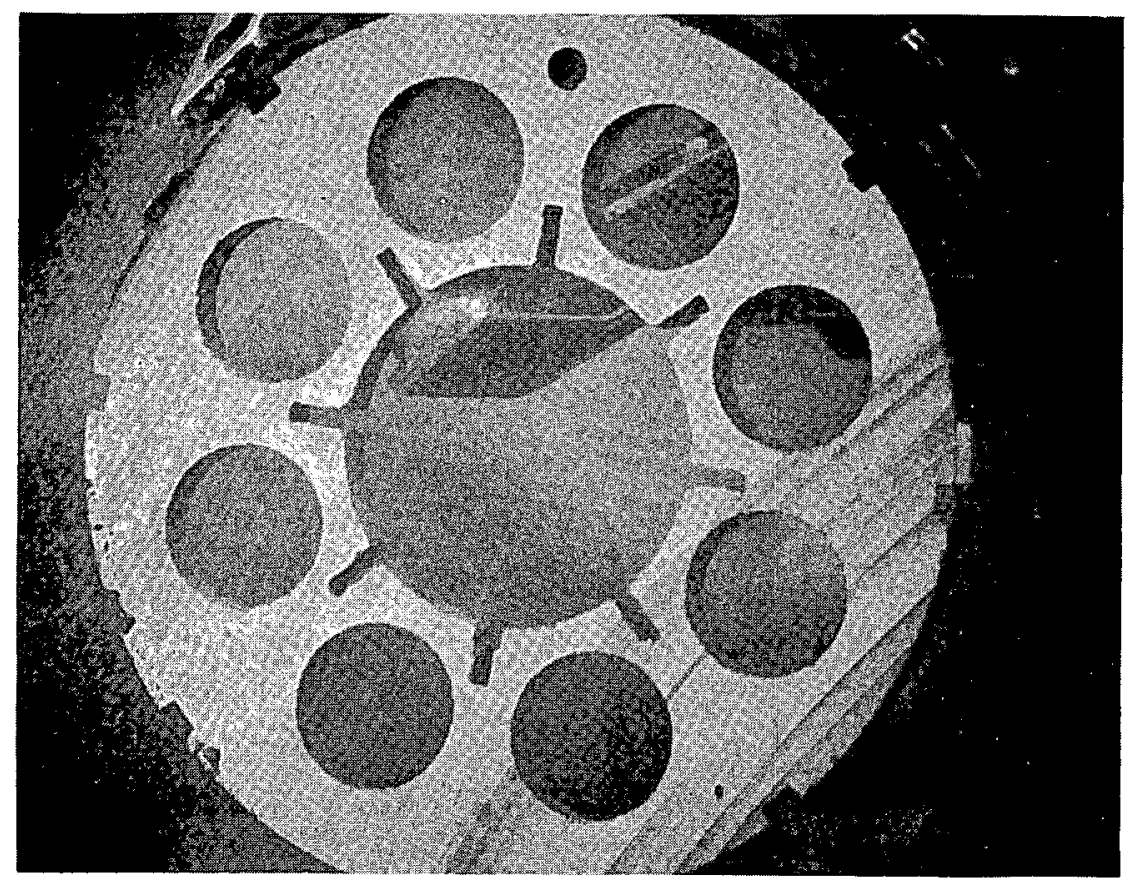

K7311-90

(a)

Slice 1-1

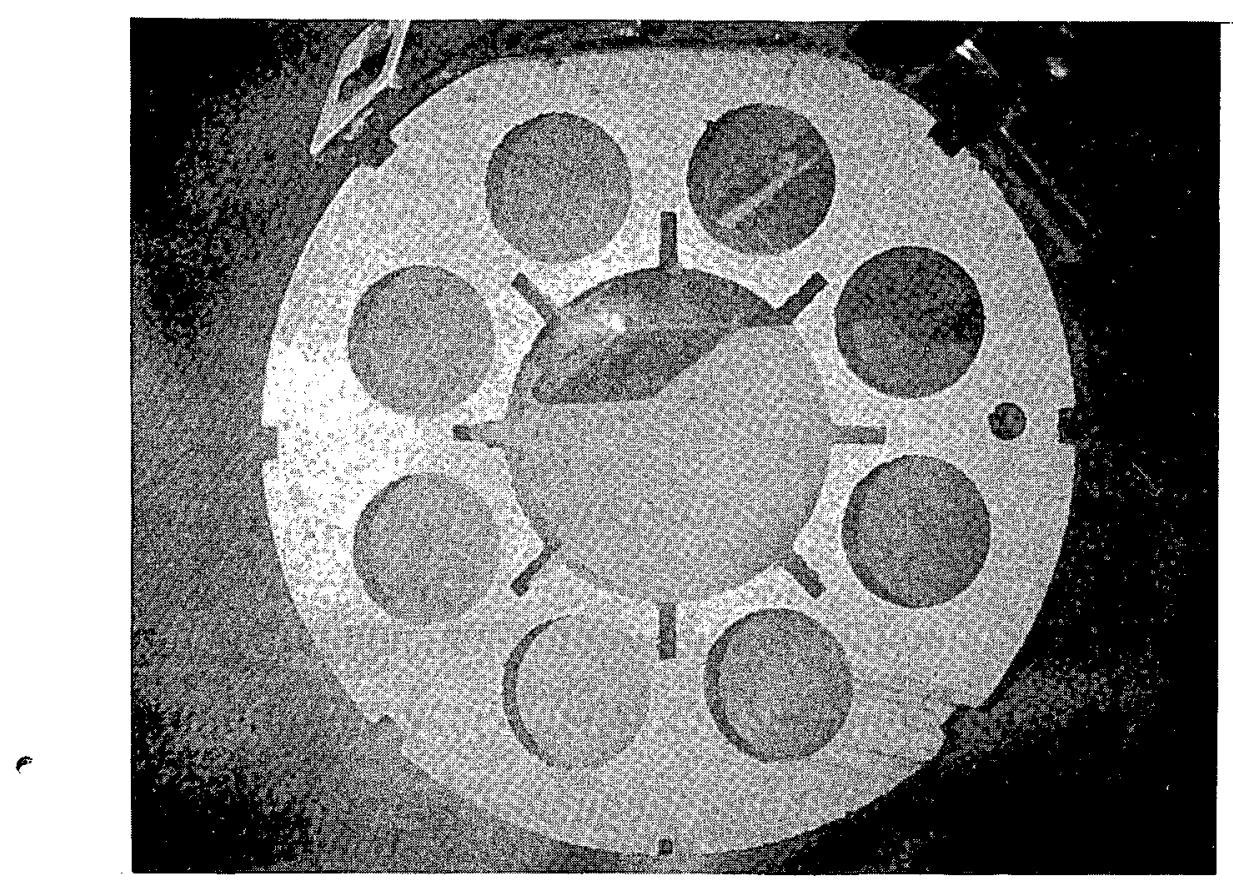

K7311-91

(b)

Slice 1-2

Fig. 15. FTE-3 bottom fuel body sections 


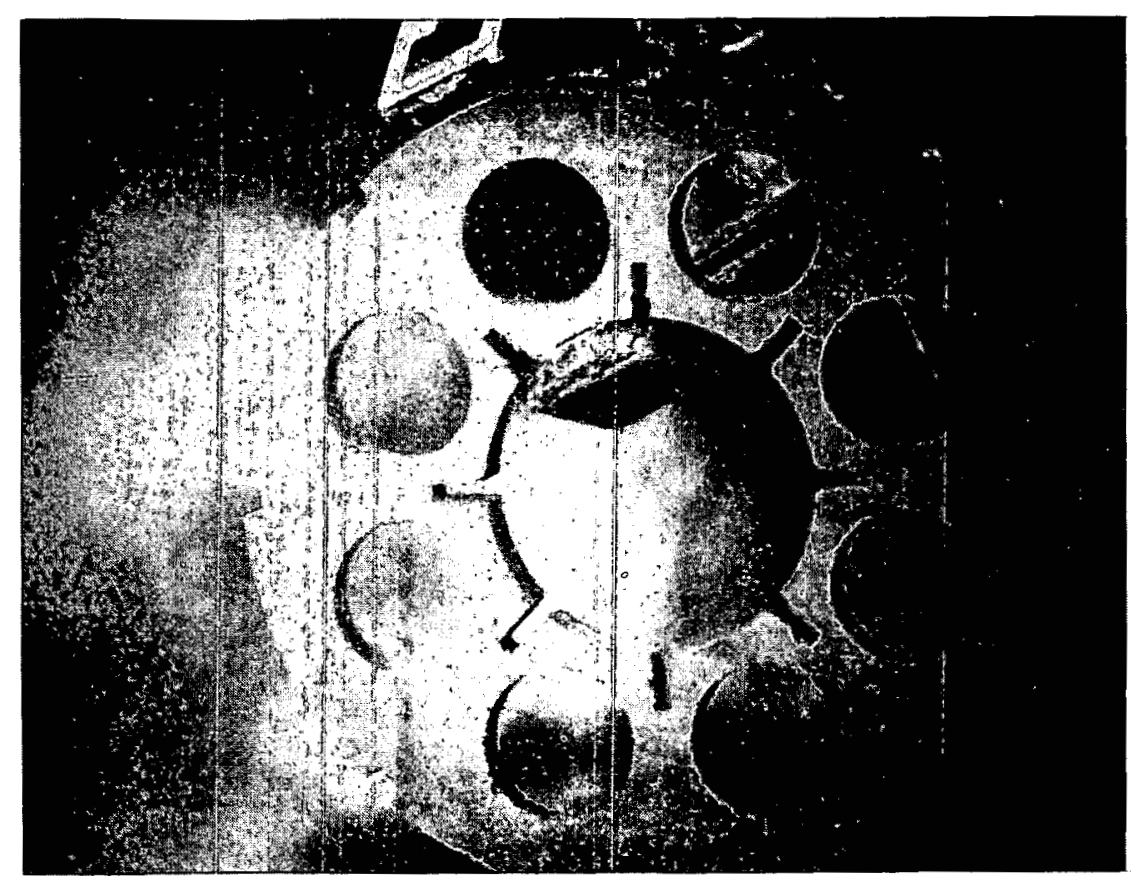

K7311-92

(a)

S1ice 2-1

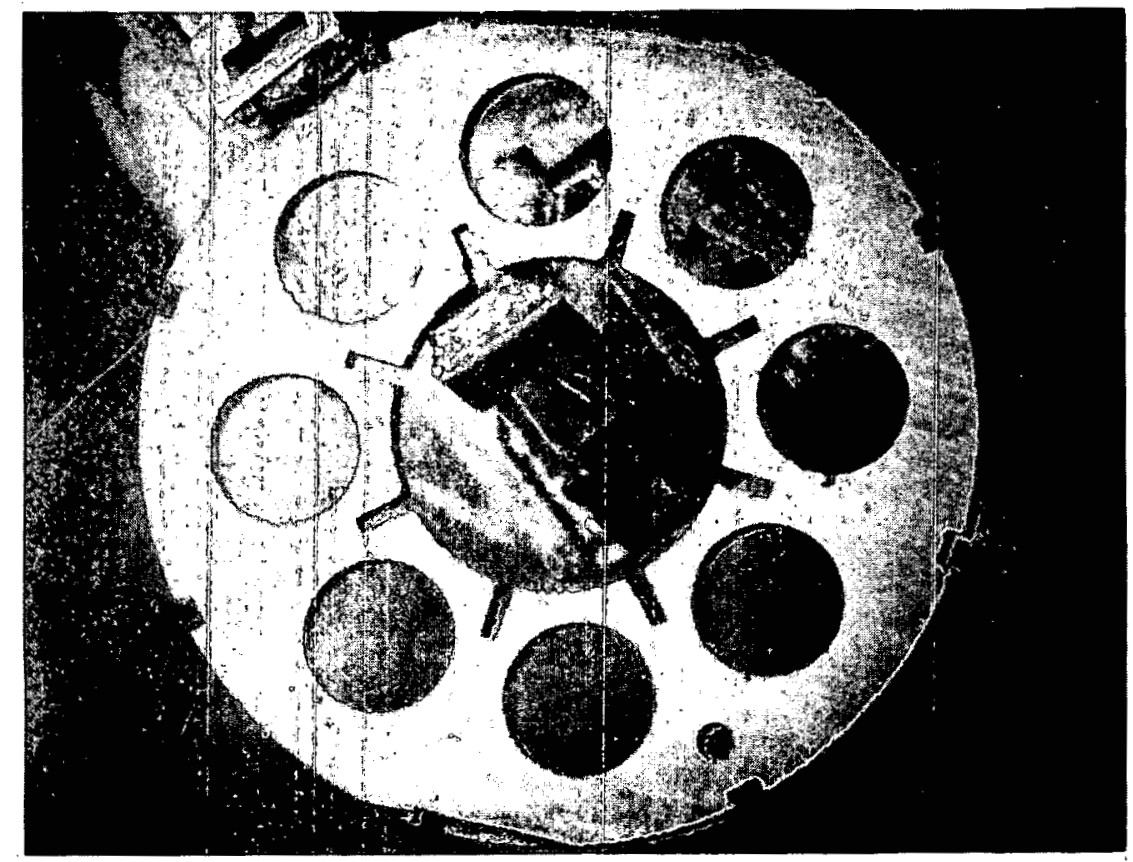

K7311-93

(b)

Slice 2-2

Fig. 16. FTE-3 center fuel body sections 


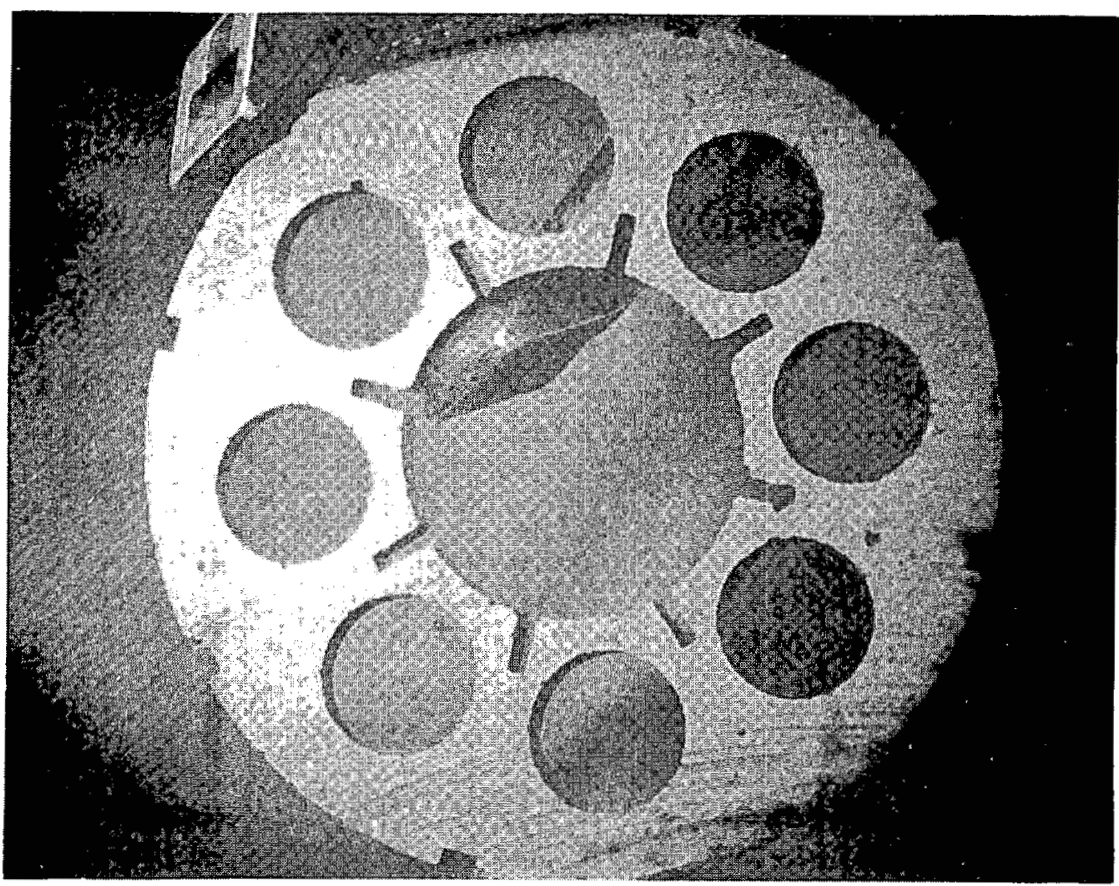

K7311-94

(a)

S1ice 3-1

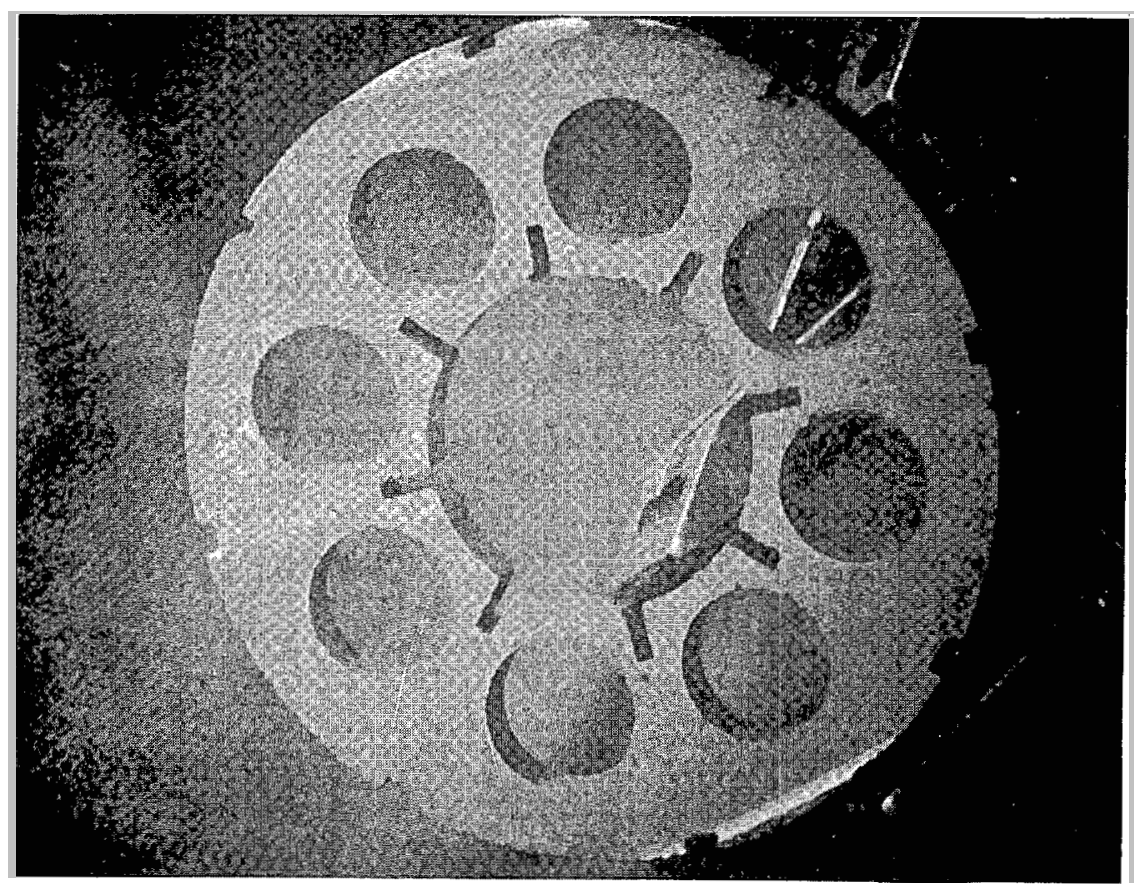

K7311-95

(b)

S1ice 3-2

Fig. 17. FTE-3 top fuel body sections 


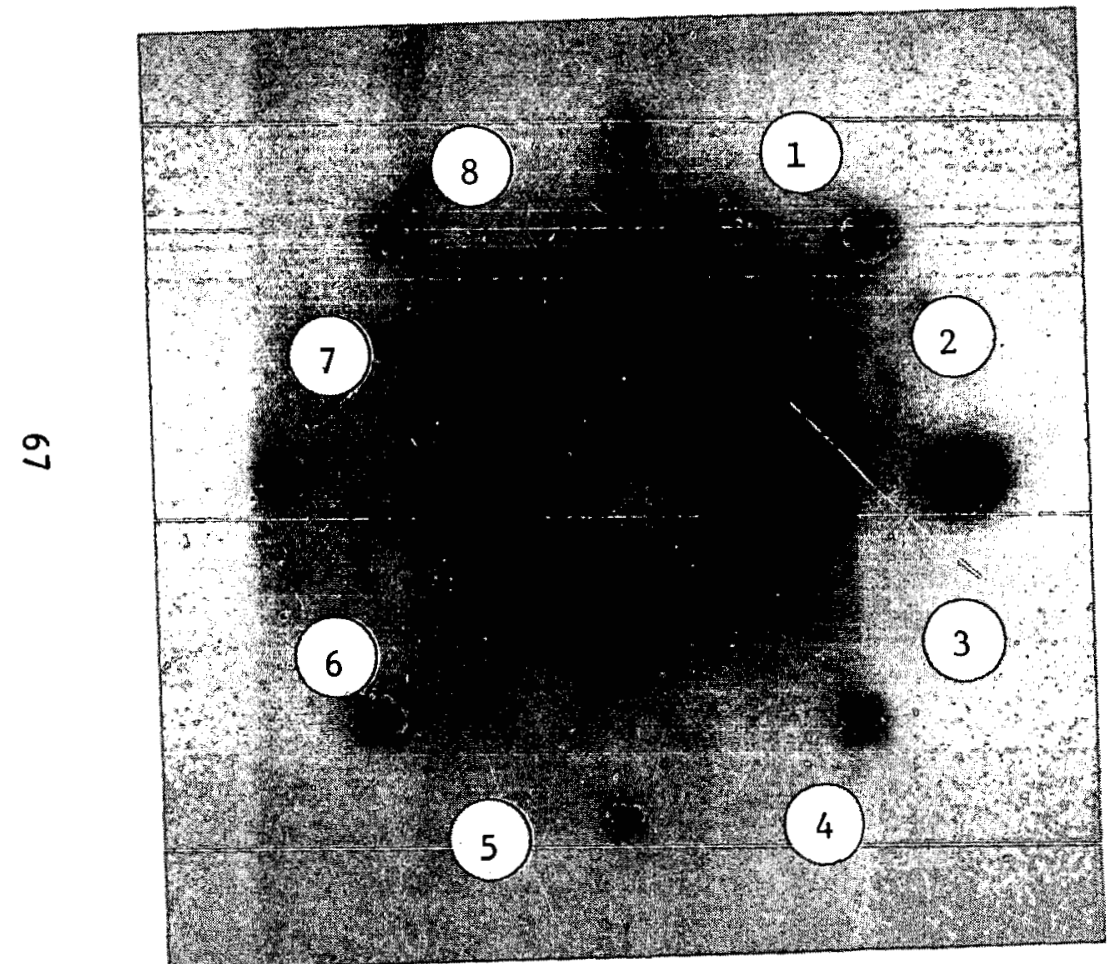

Slice $1-1$ at 11.7 in. active core height

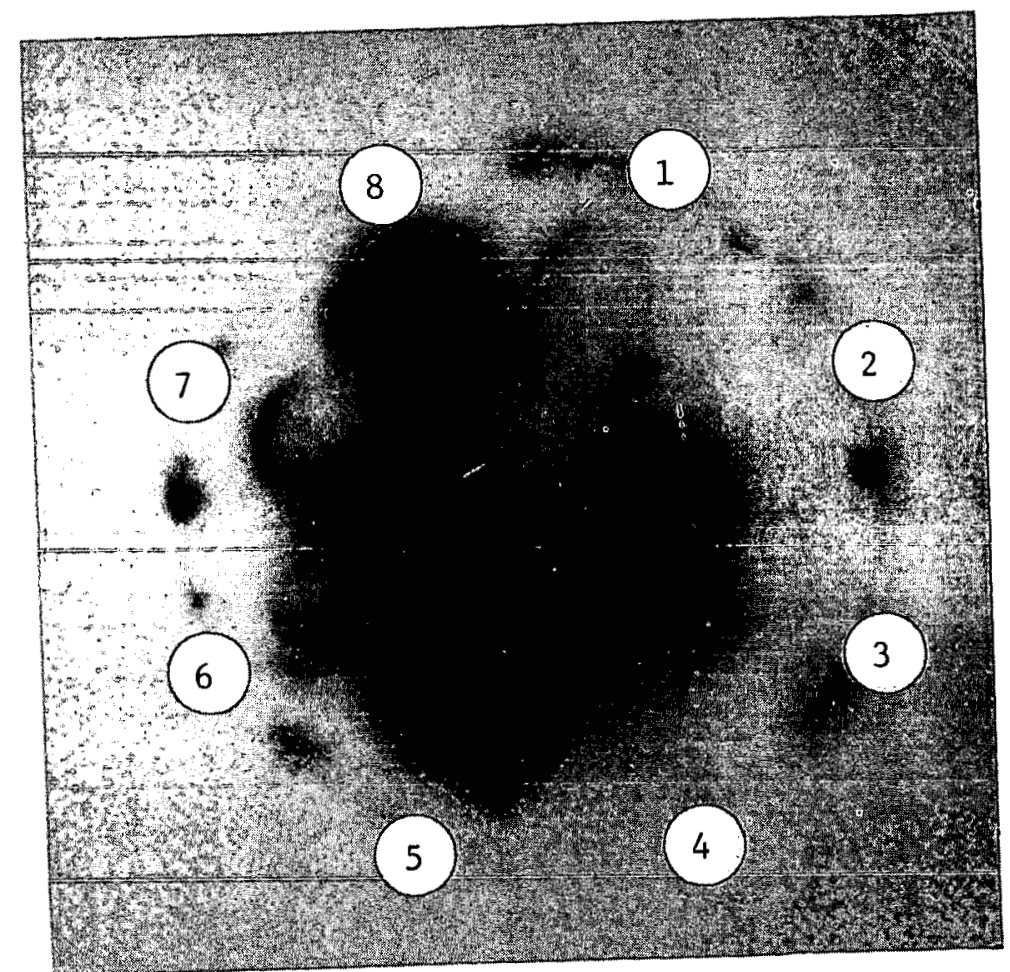

S1ice $1-2$ at $1.8 \mathrm{in}$. active core height

Fig. 18. Autoradiographs from bottom body FTE-3/1 


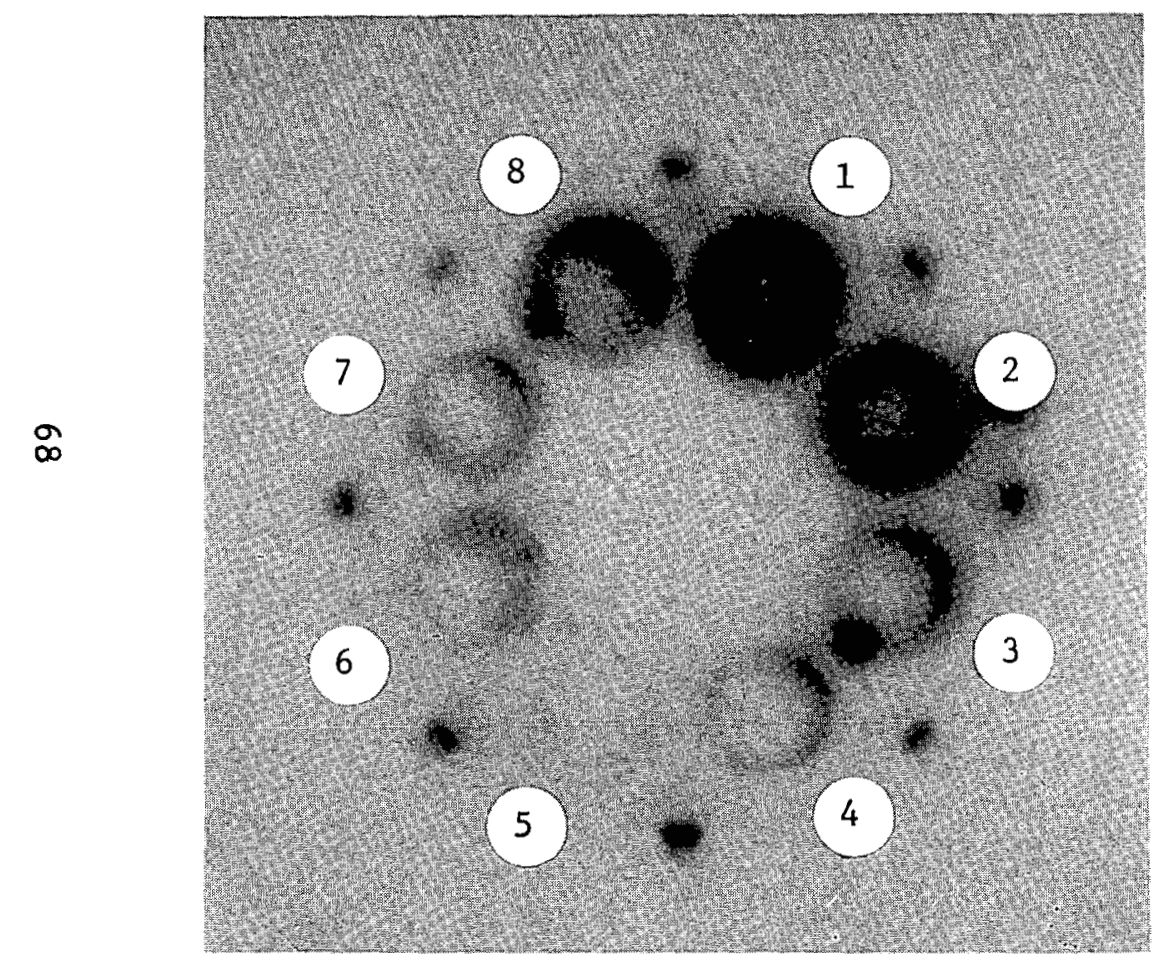

Slice 2-1 at 57.8 in. active core height

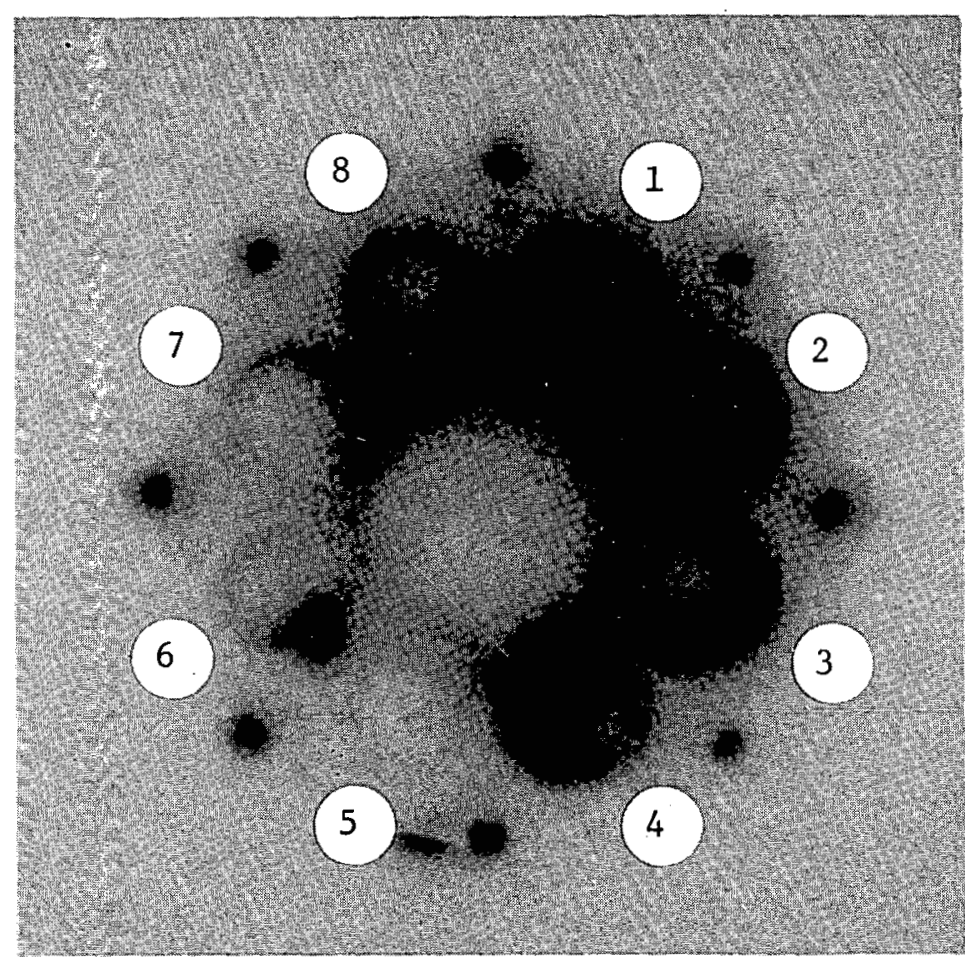

Slice $2-2$ at 33.9 in. active core height

Fig. 19. Autoradiographs from center body FTE-3/2 


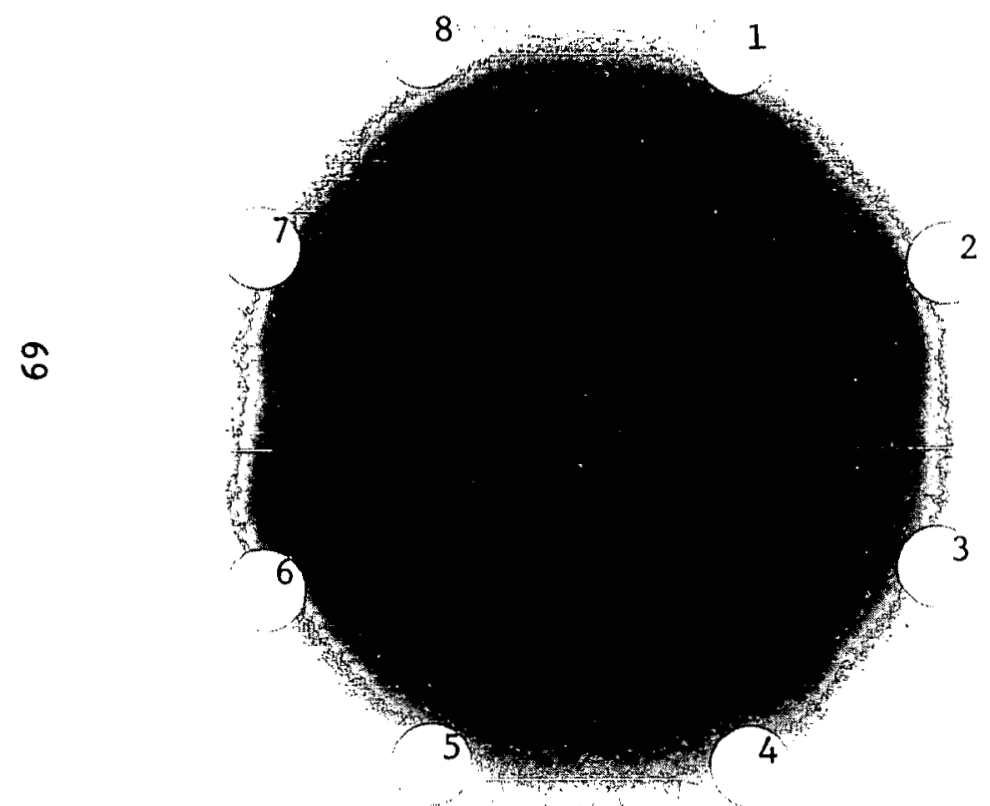

Slice $3-1$ at 85.1 in. active core height

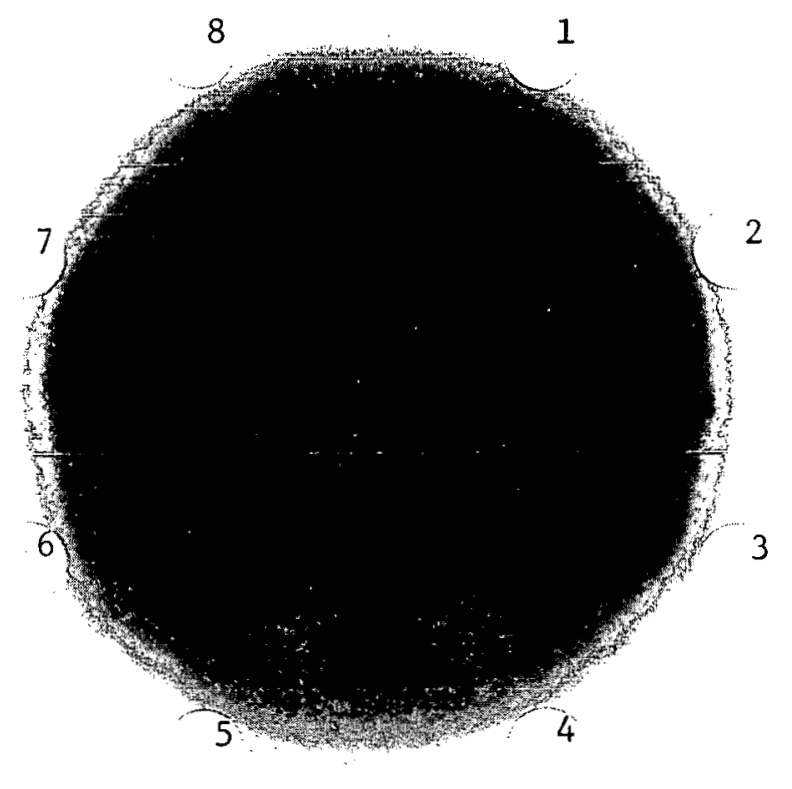

Slice $3-2$ at 79.0 in. active core height

Fig. 20. Autoradiographs from top body FTE $3 / 3$ 


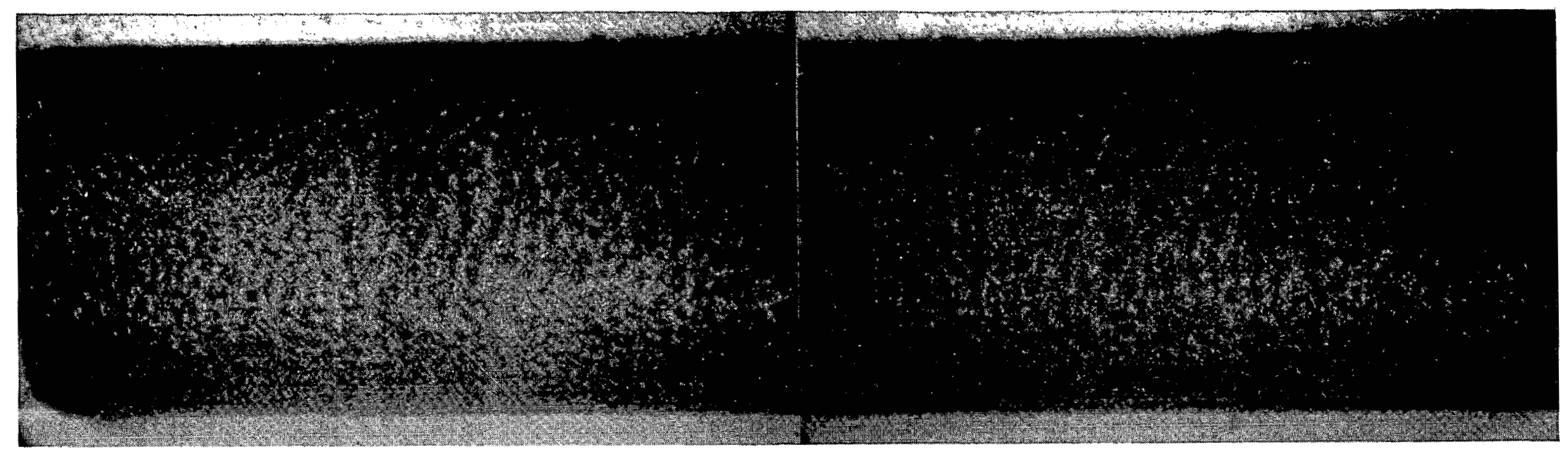

S7311-31, 32

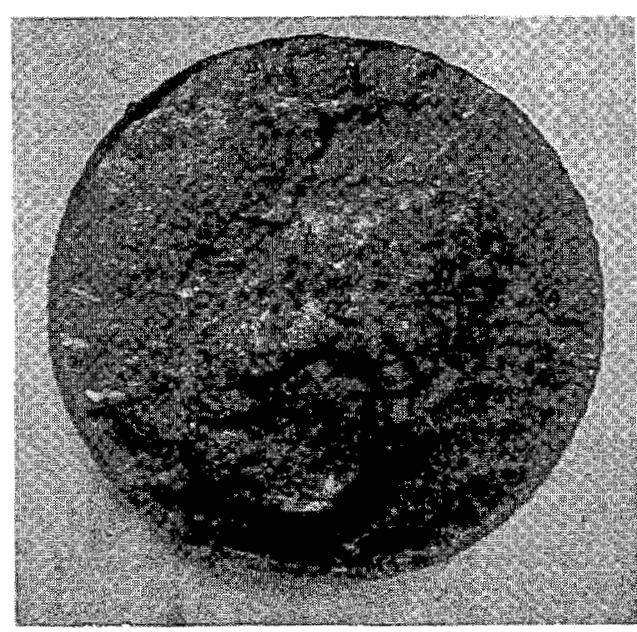

S7311-28

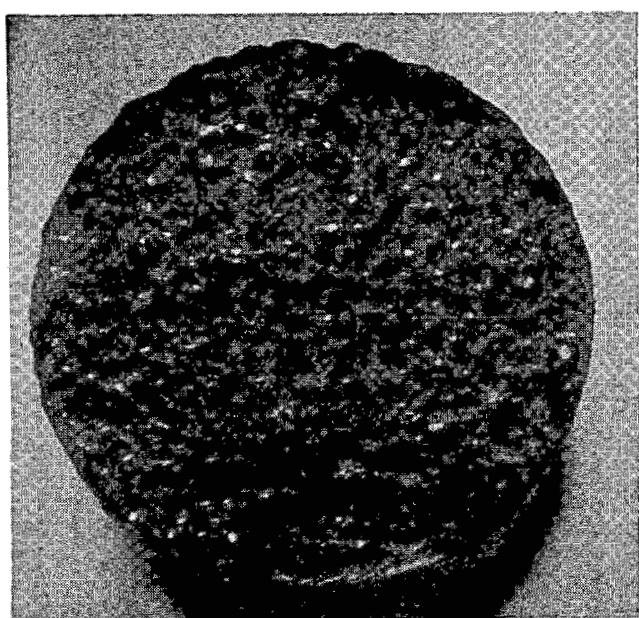

S7311-27

Fig. 21. FTE-3 fuel rod 1-1-9 visual examination. Irradiation to $0.52 \times 10^{21} \mathrm{n} / \mathrm{cm}^{2}$ at $773^{\circ} \mathrm{C}$. Rod 1-1-9 contained a blend of $\mathrm{UO}_{2}$ TRISO fissile and $\mathrm{ThO}_{2}$ BISO fertile particles

0 

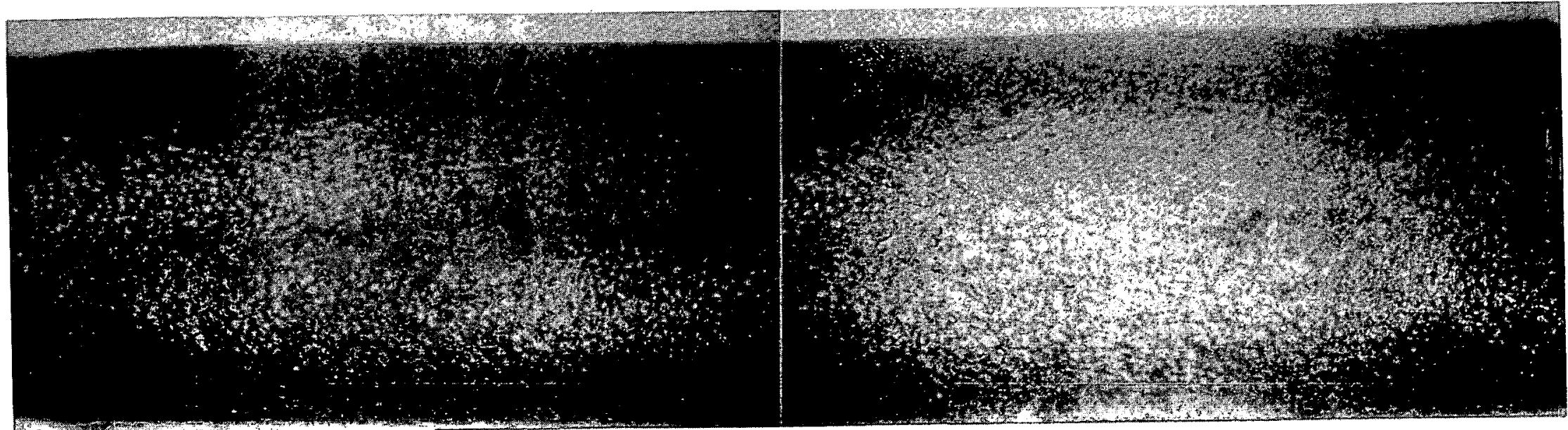

$57311-23,24$

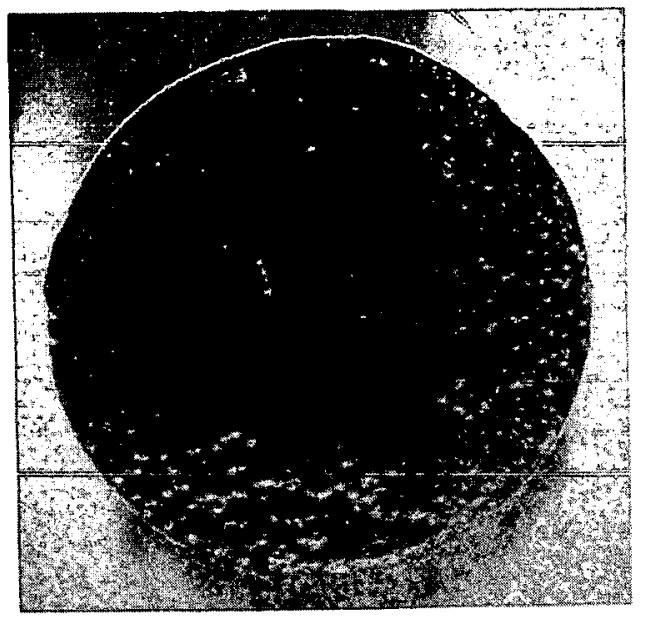

S7311-22

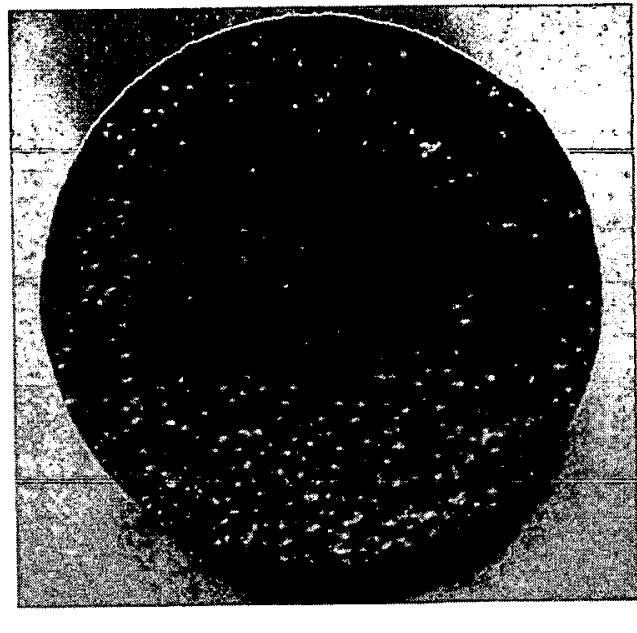

S7311-21

ح X

Fig. 22. FTE-3 Fuel rod 2-8-7 visual examination. Irradiation to $0.58 \times 10^{21} \mathrm{n} / \mathrm{cm}^{2}$ at $912^{\circ} \mathrm{C}$. Fuel rod 2-8-7 contained a blend of $\mathrm{UC}_{2}$ TRISO fissile and $\mathrm{ThC}_{2}$ BISO fertile particles 


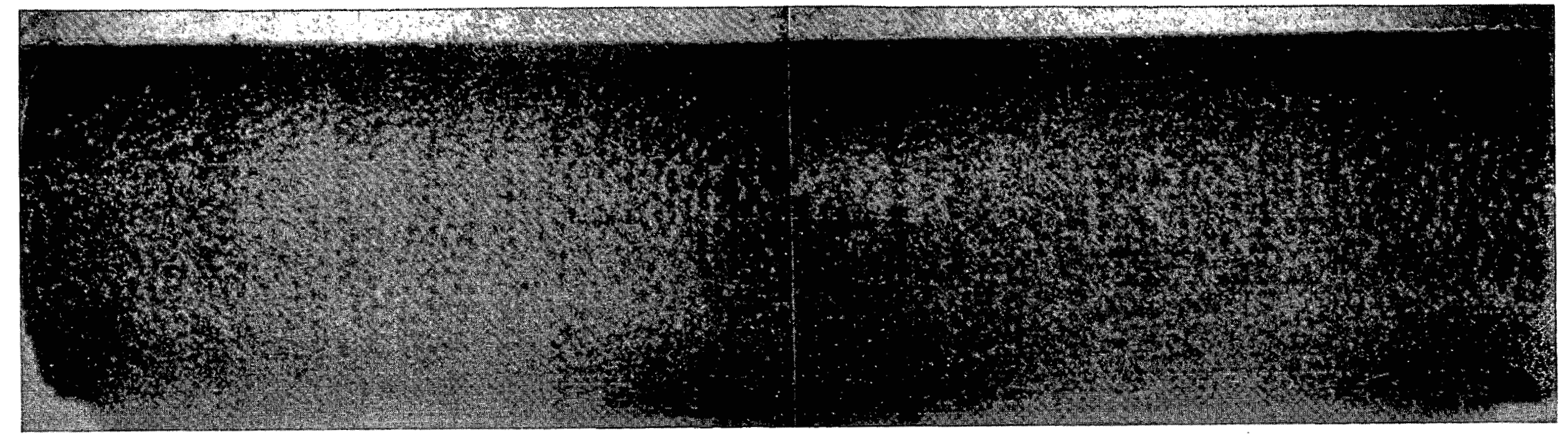

57311-11,12

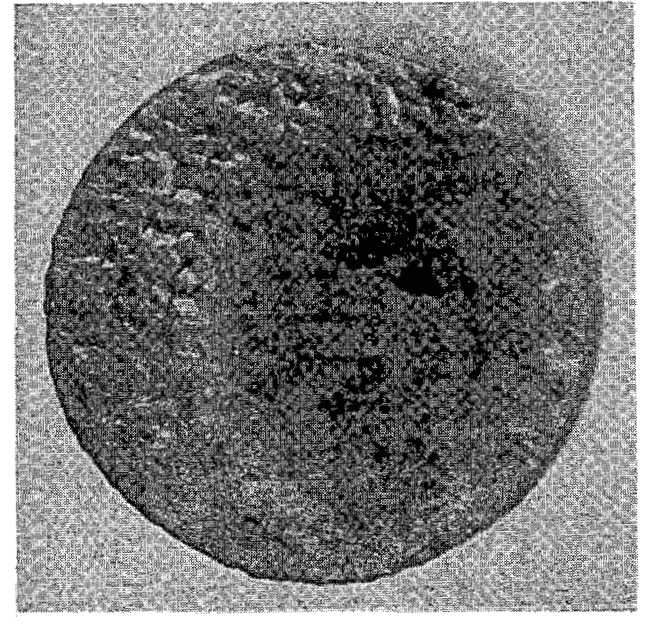

S7311-9

$\sim 4 X$

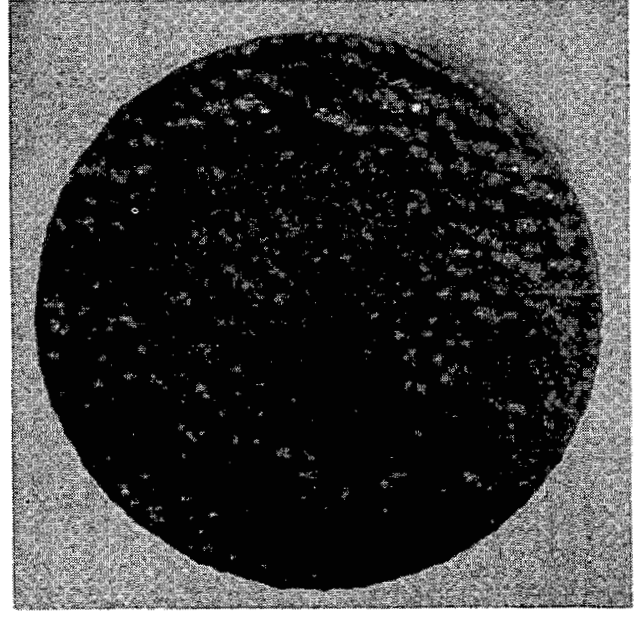

57311-10

$v 4 \mathrm{X}$

Fig. 23. FTE-3 fuel rod 2-3-7 visual examination. Irradiation to $0.58 \times 10^{21} \mathrm{n} / \mathrm{cm}^{2}$ at $912^{\circ} \mathrm{C}$. Fuel rod 2-3-7 contained a blend of $(\mathrm{Th}, \mathrm{U}) \mathrm{C}_{2}$ TRISO fissile and $\mathrm{ThC}_{2}$ BISO fertile particles

O. 


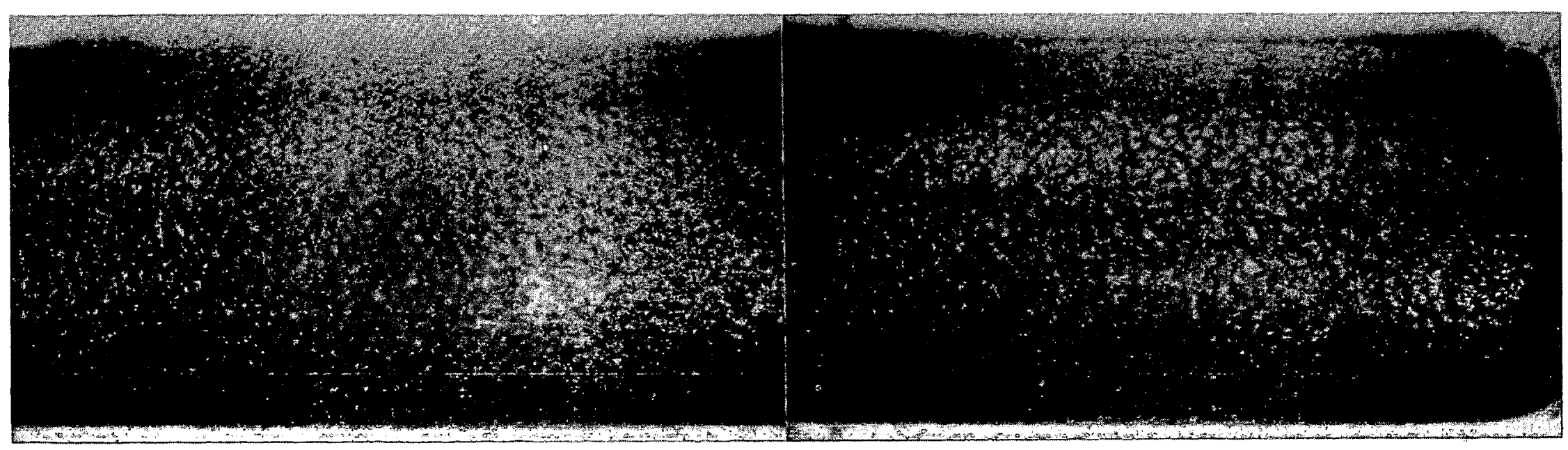

S7311-15,16

$\tilde{\omega}$

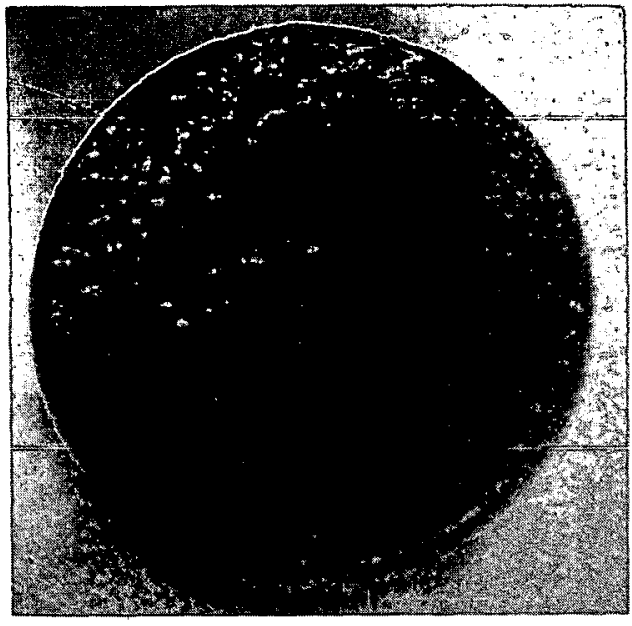

S7311-20

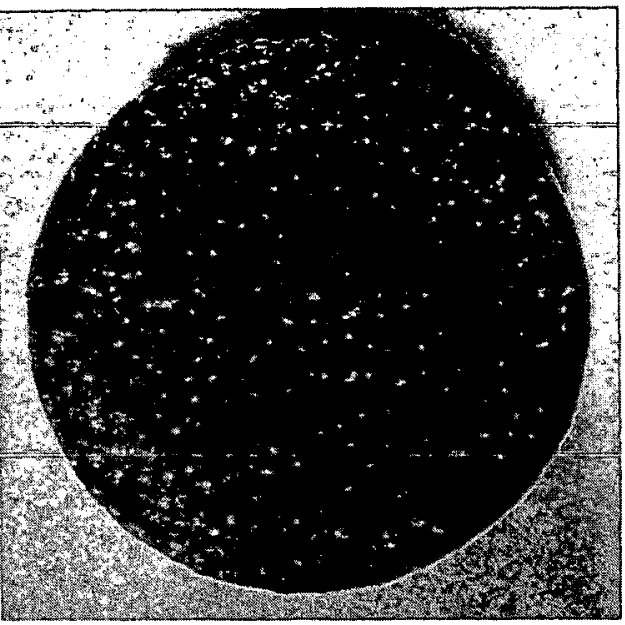

S7311-19

$\sim 4 X$

Fig. 24. FTE-3 fuel rod 2-5-7 visual examination. Irradiation to $0.58 \times 10^{21} \mathrm{n} / \mathrm{cm}^{2}$ at $912^{\circ} \mathrm{C}$. Fuel rod 2-5-7 contained a blend of ( $\mathrm{Th}, \mathrm{U}) \mathrm{C}_{2}$ TRISO fissile and $\mathrm{ThC}_{2}$ TRISO fertile particles 


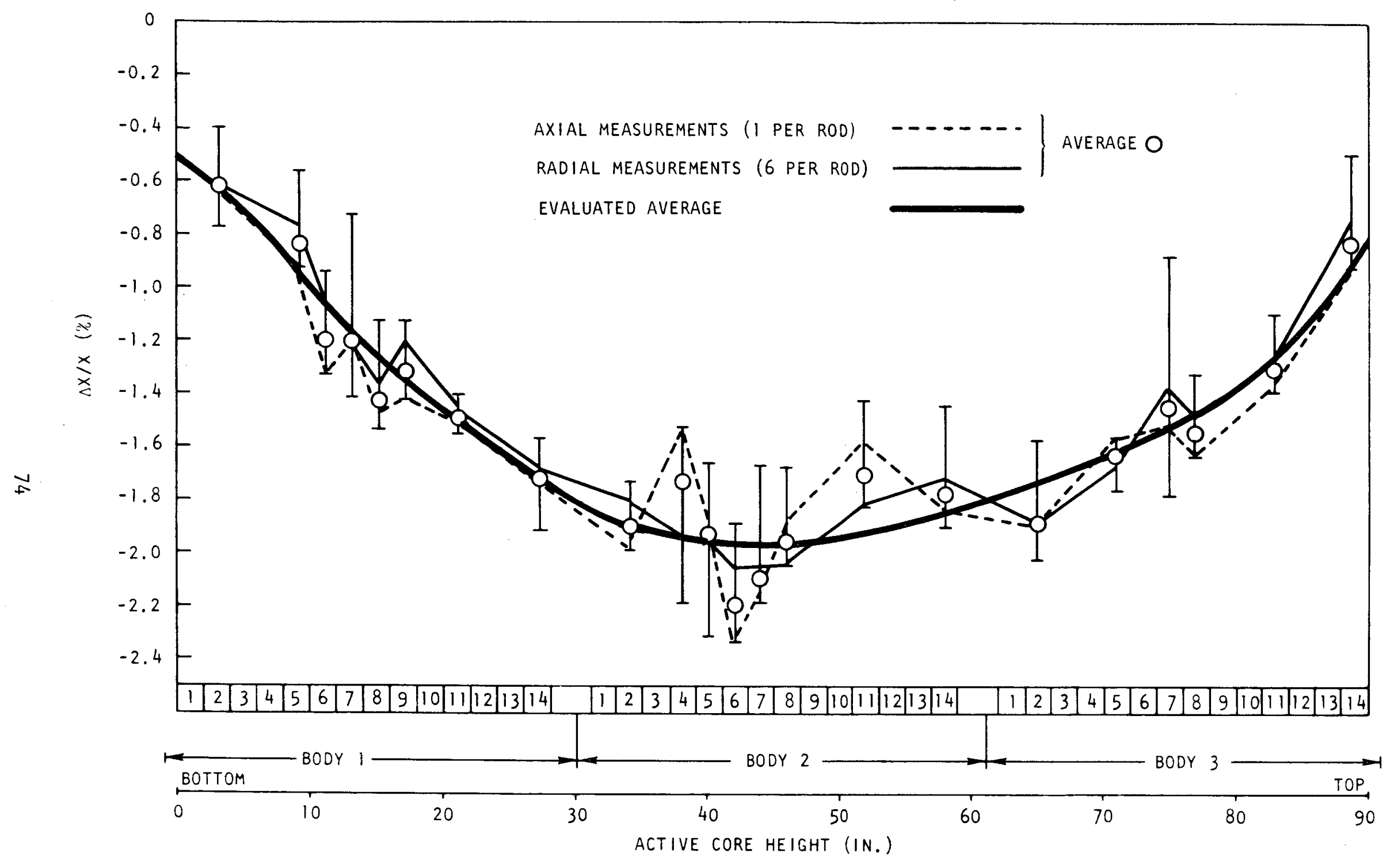

Fig. 25. FTE-3 fuel rod dimensional changes for $\mathrm{UO}_{2} \mathrm{TRISO} \mathrm{ThO}_{2} \mathrm{BISO}$ fuel (holes 1 and 2 )

o. 


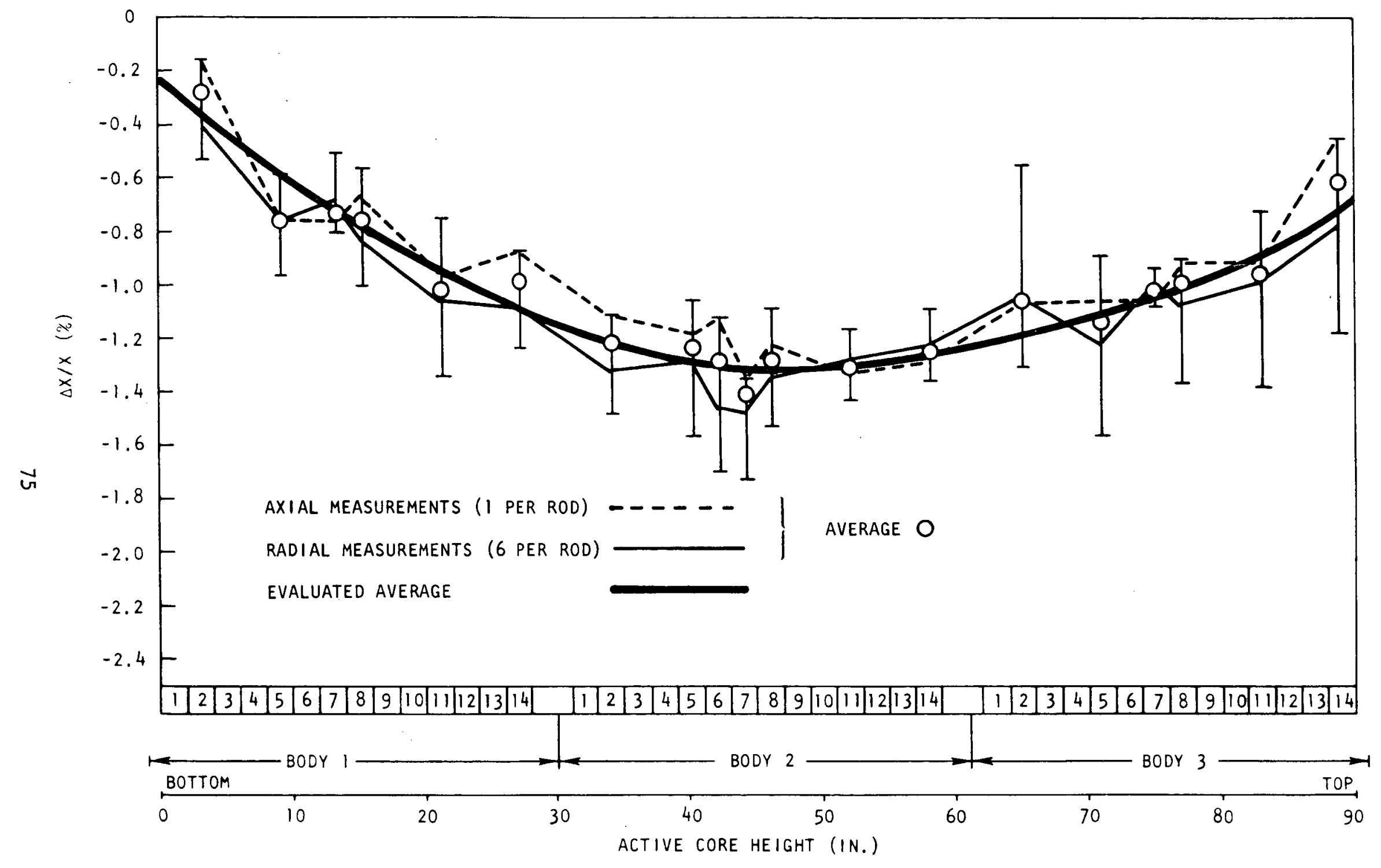

Fig. 26. FTE-3 fuel rod dimensional changes for (2.75 Th:U) $\mathrm{C}_{2}$ TRISO, ThC ${ }_{2}$ BISO fuel (holes 3 and 4) 


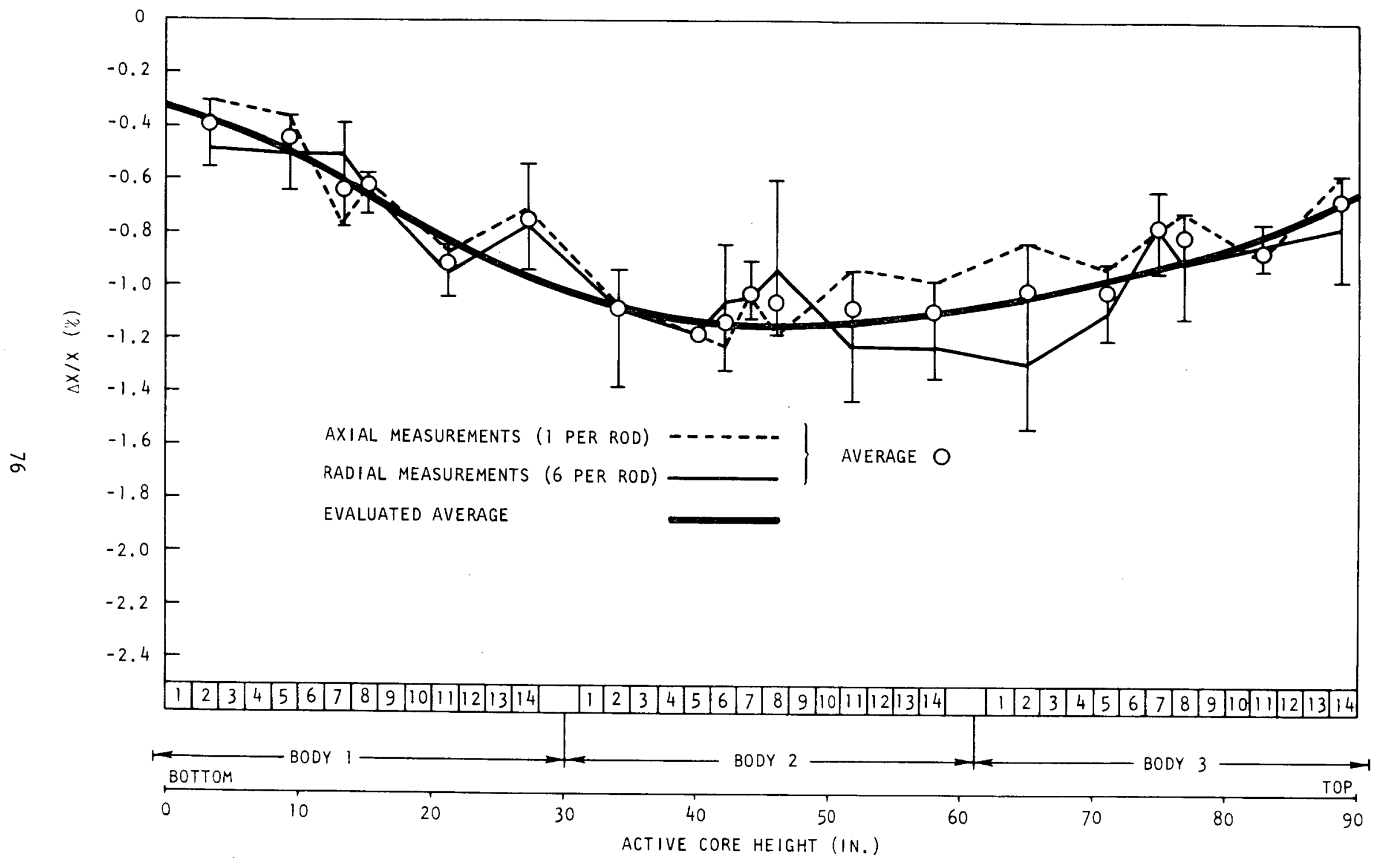
Fig. 27. FTE-3 fuel rod dimensional changes for $\left(2.75\right.$ Th:U) $C_{2}$ TRISO, ThC 2 TRISO fuel
(holes 5 and 6 ) 


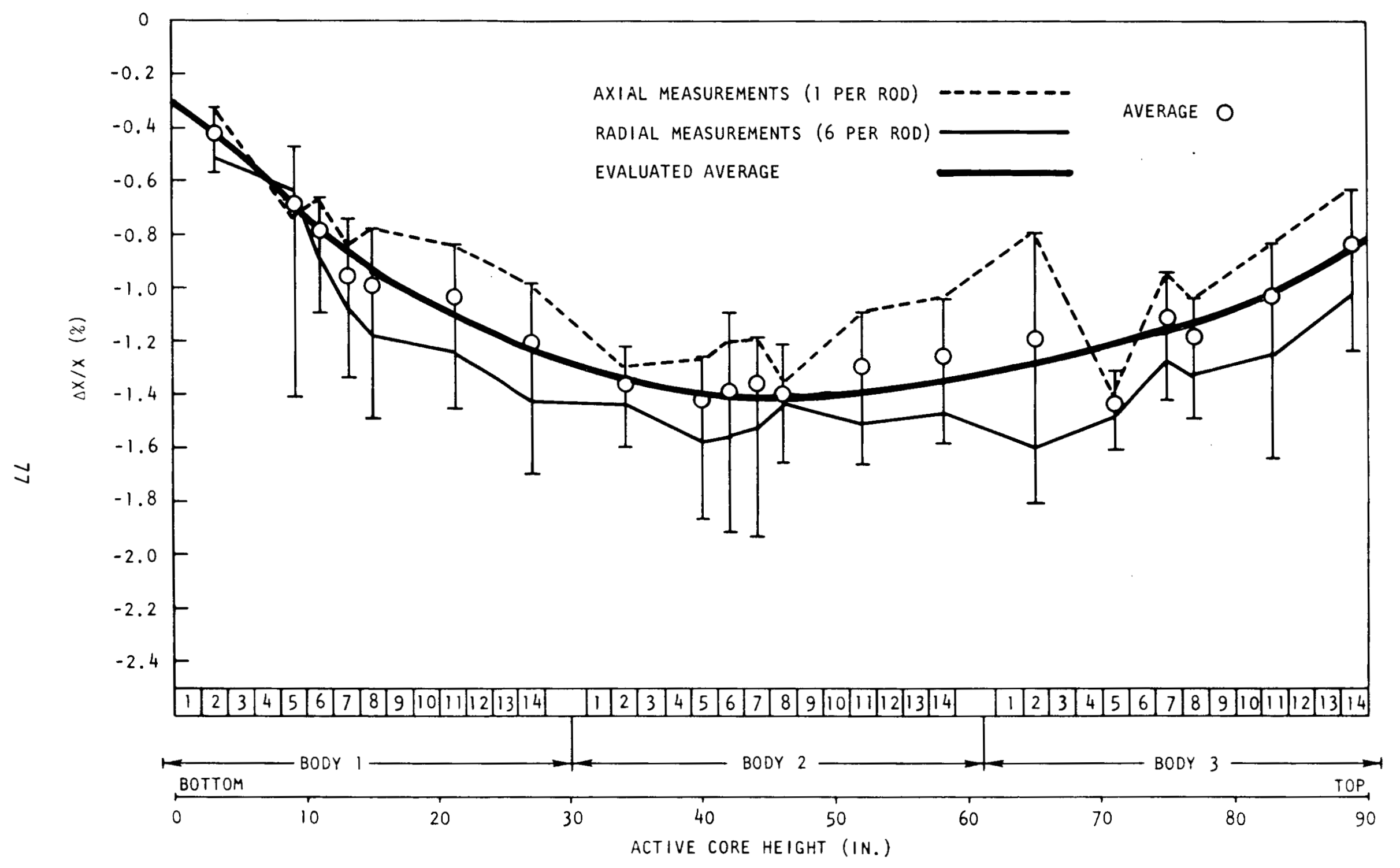

Fig. 28. FTE-3 fuel rod dimensional changes for $\mathrm{UC}_{2}$ TRISO, ThC 2 BISO fuel (holes 7 and 8) 


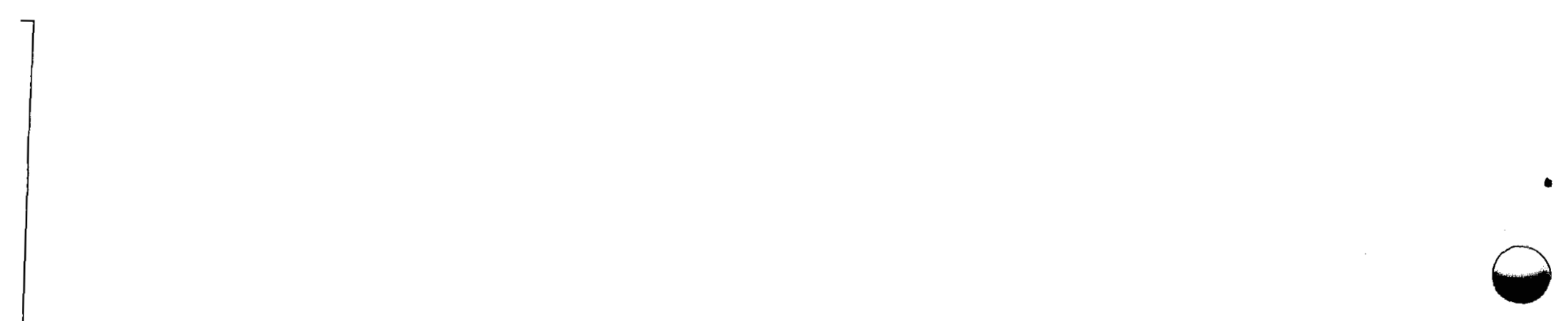




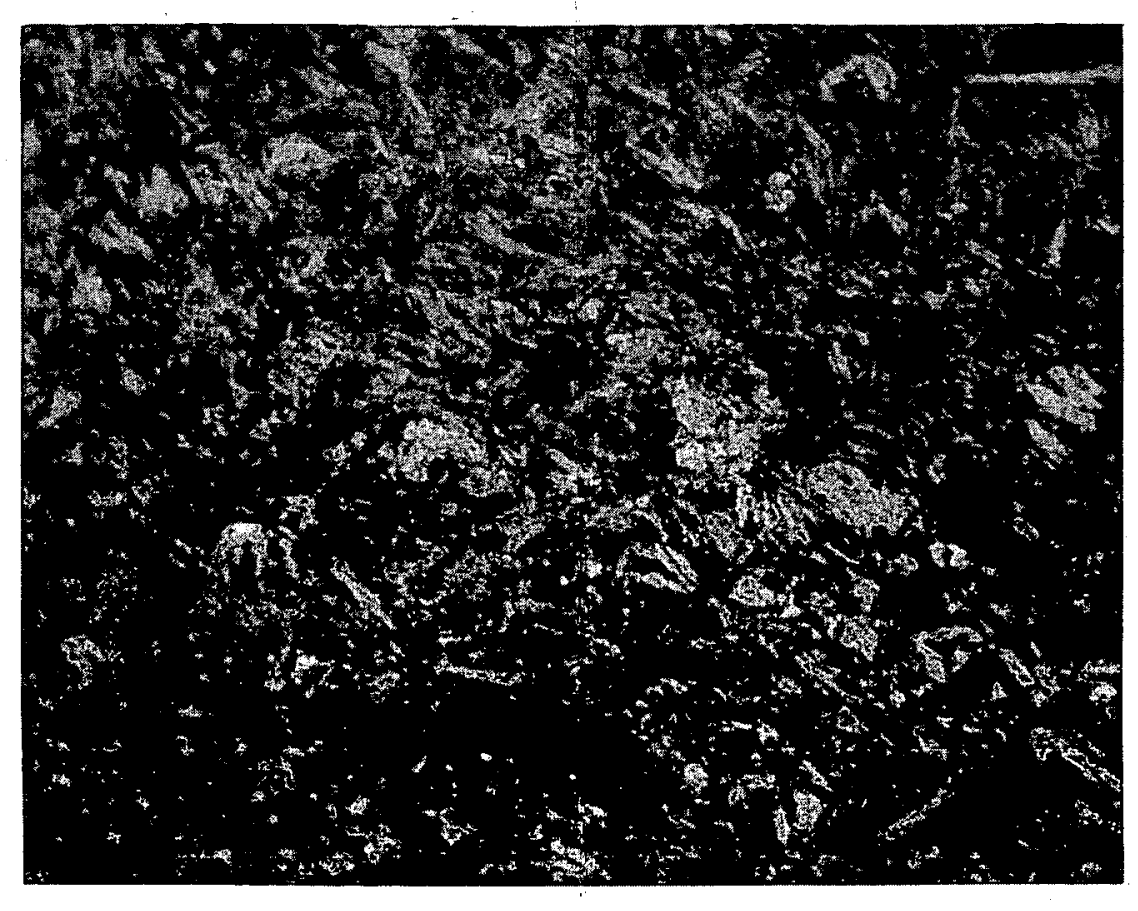

L7311-57

(a)

$650 \mathrm{x}$
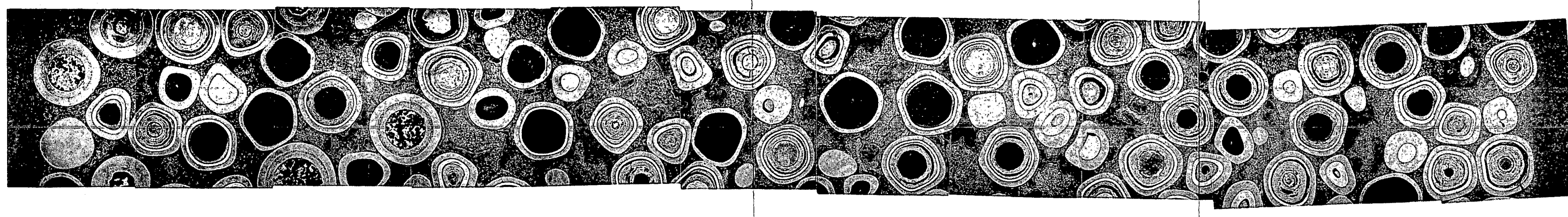

Fig. 29. FTE-3 photomicrographs of fuel rod 2-3-7. Irradiation condition: $0.58 \times 10^{21} \mathrm{n} / \mathrm{cm}^{2}(\mathrm{E}>18 \mathrm{MeV})$ at $912^{\circ} \mathrm{C}$. showing radial cross section 


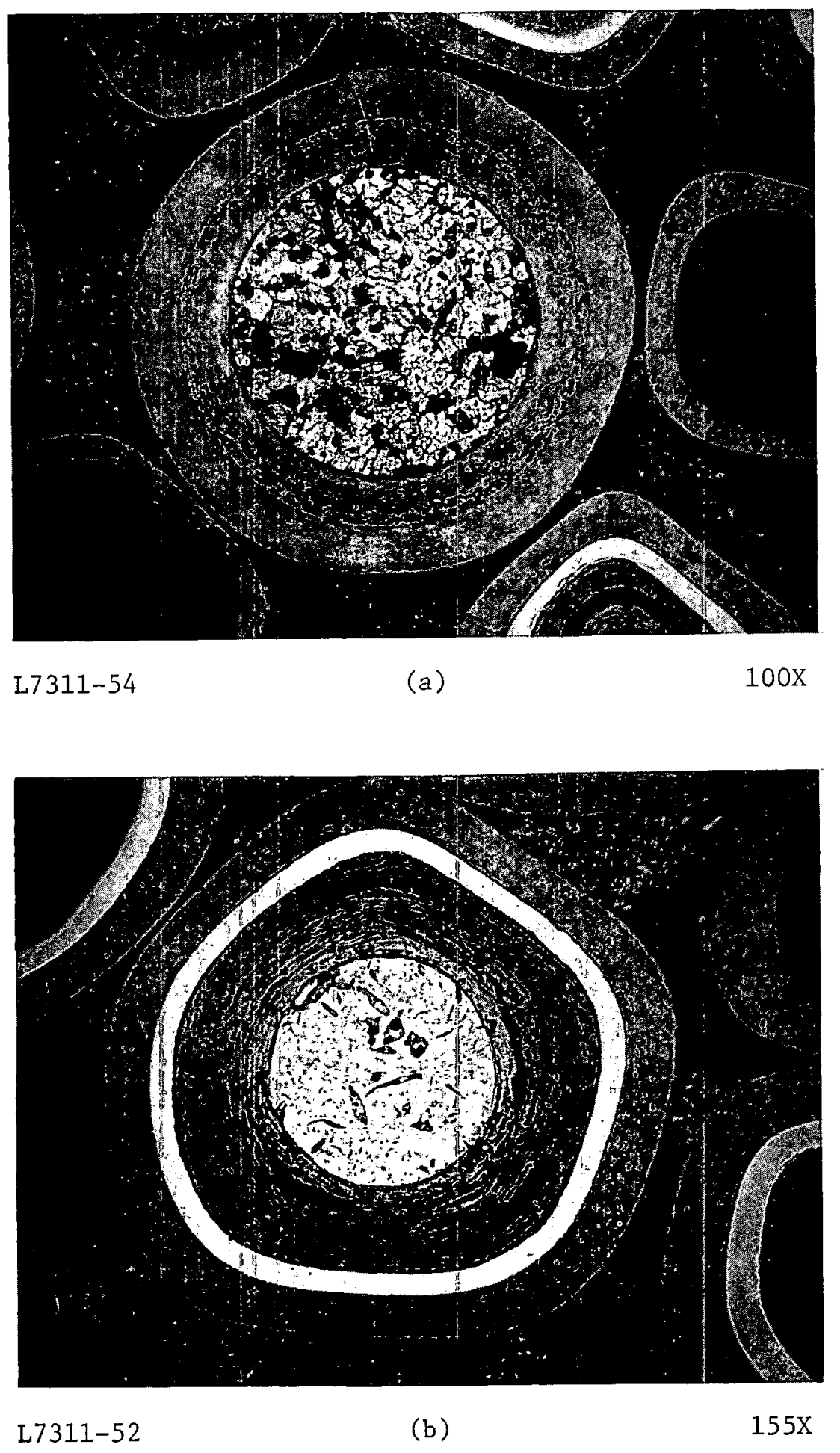

Fig. 30. FTE-3 photomicrographs of representative particles from fuel rod 2-3-7. Irradiation condition $0.58 \times 10^{21} \mathrm{n} / \mathrm{cm}^{2}$ at $912^{\circ} \mathrm{C}$. (a) $\mathrm{ThC}_{2}$ BISO particle. (b) $(\mathrm{Th}, \mathrm{U}) \mathrm{C}_{2}$ TRISO particle 


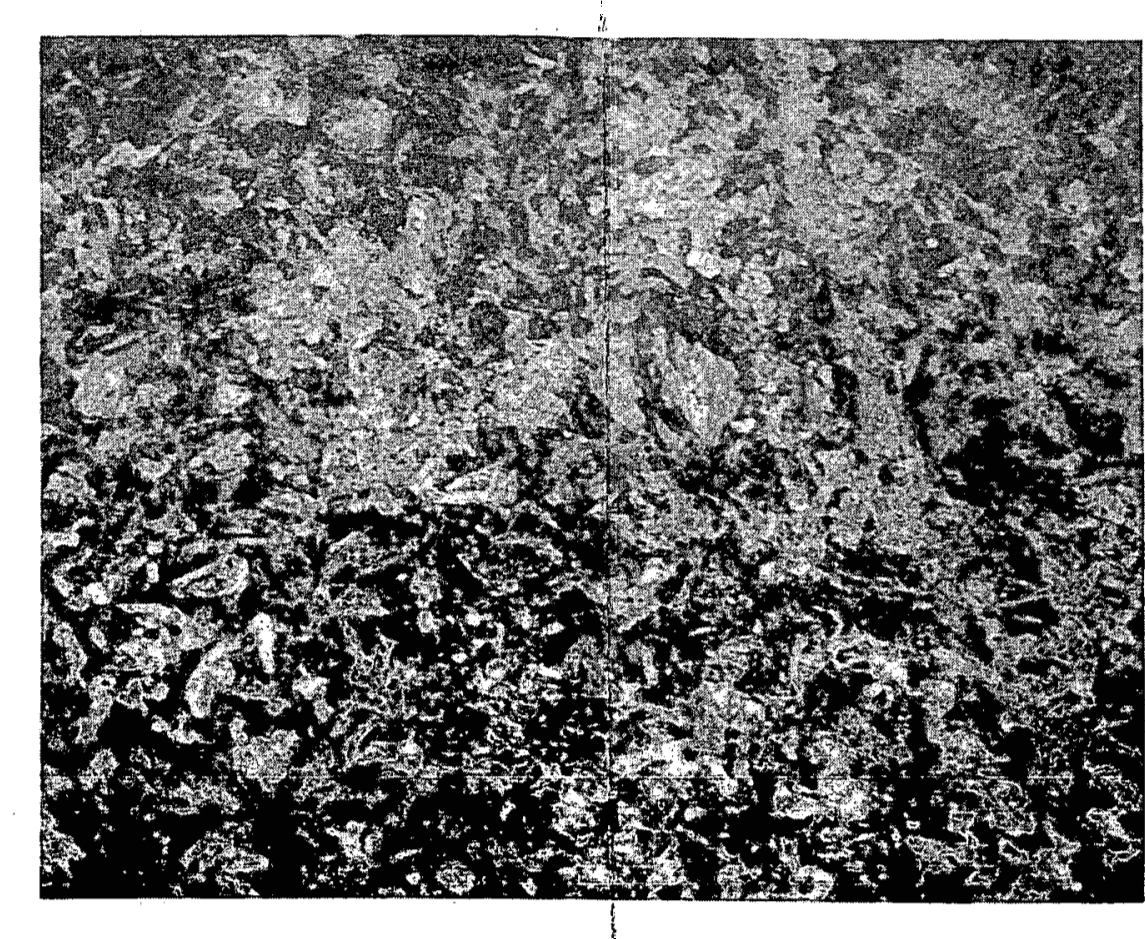

L7311-36

(a)

650x

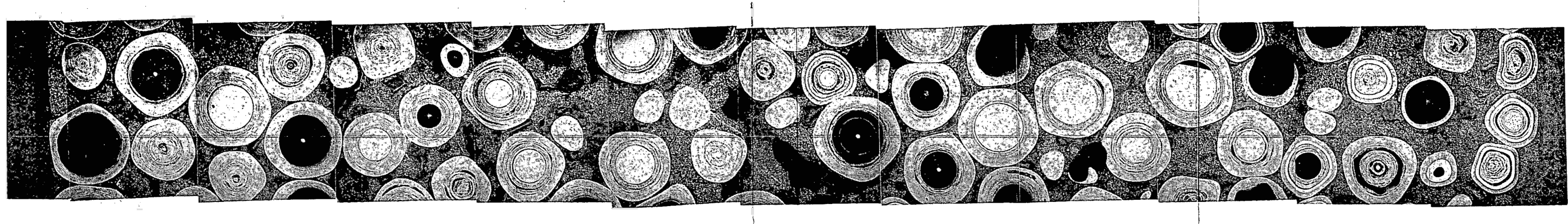





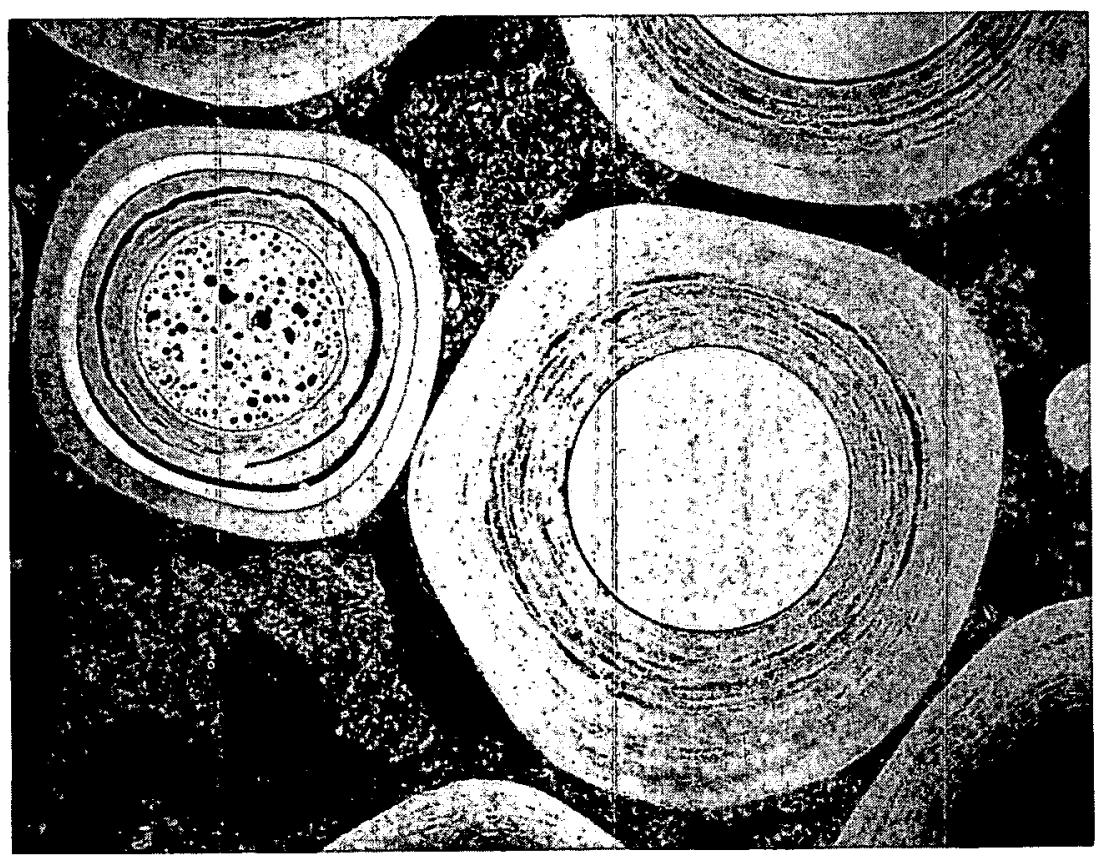

L7311-24

(a)

$85 X$

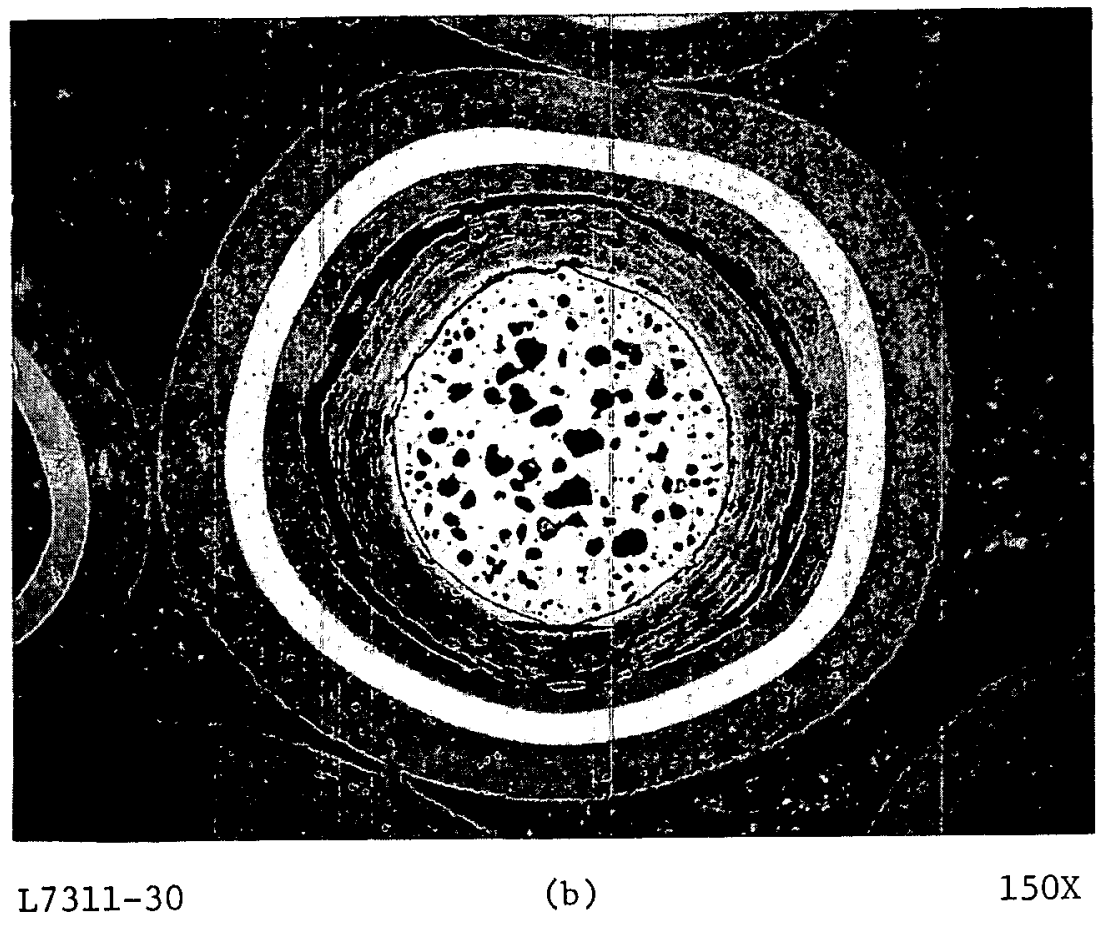

Fig. 32. FTE-3 photomicrographs of representative particles from fuel rod 2-2-7. Irradiation condition $0.58 \times 10^{21} \mathrm{n} / \mathrm{cm}^{2}$ at $912^{\circ} \mathrm{C}$. (a) $\mathrm{UO}_{2}$ TRISO and $\mathrm{ThO}_{2}$ BISO particles. (b) $\mathrm{UO}_{2}$ TRISO particle 


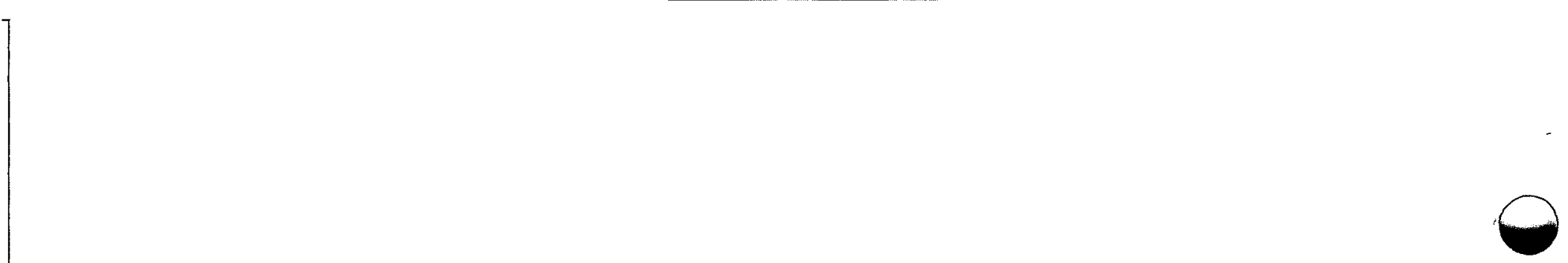

。

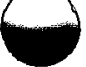

3 


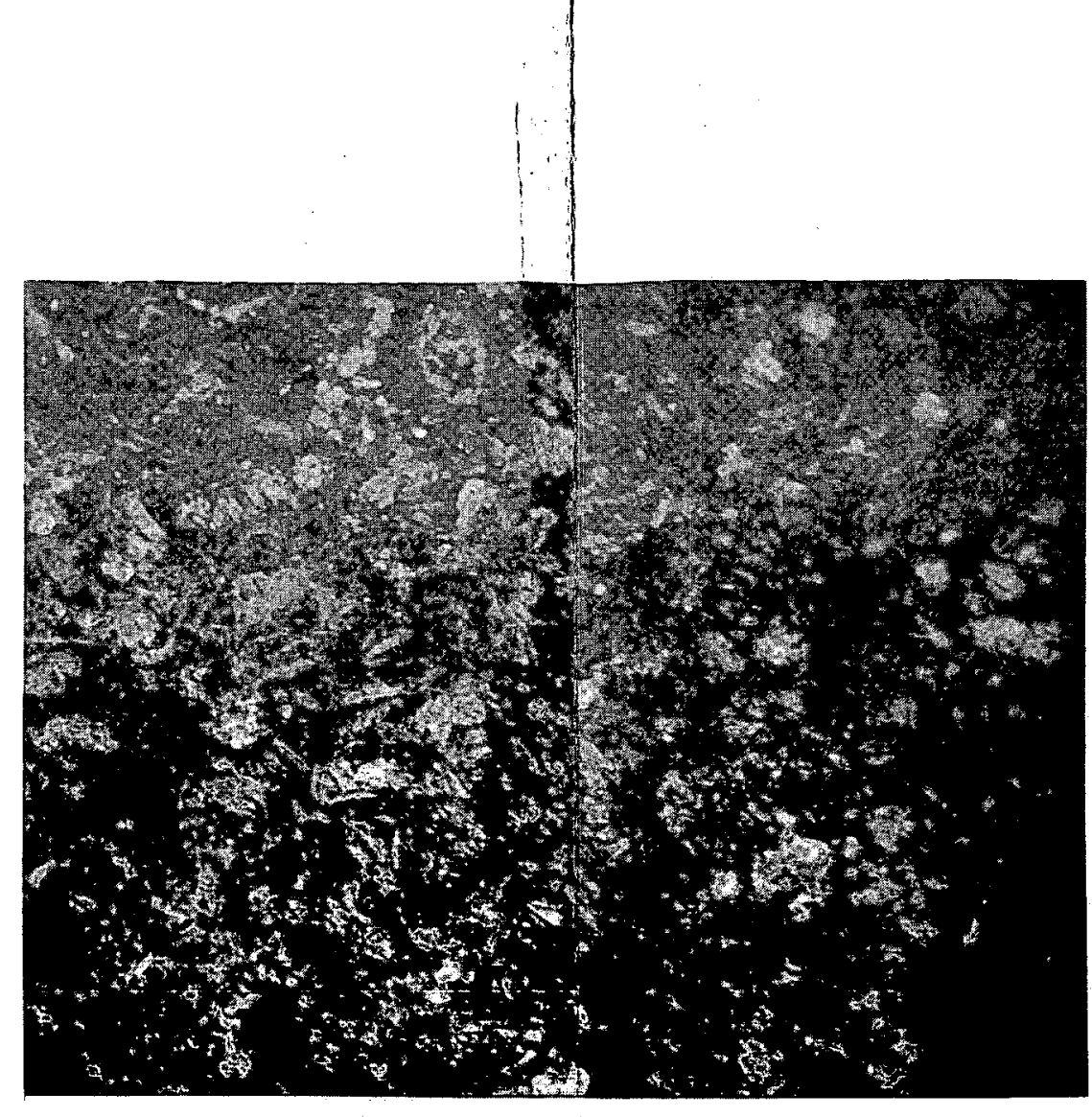

. L7311-120

(a)

650X

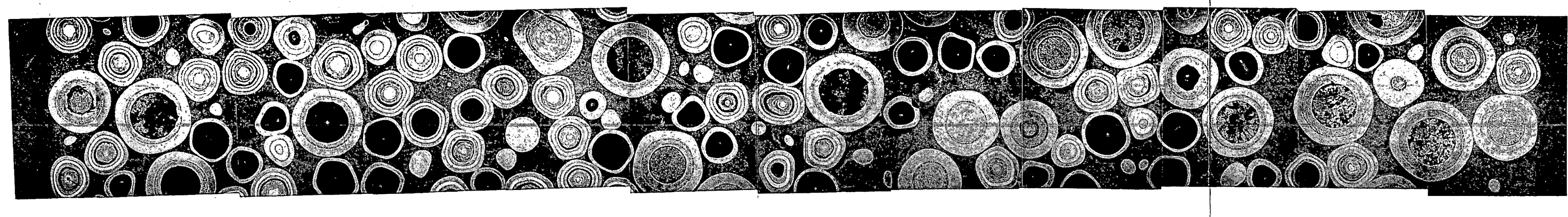

Fig. 33. FTE-3 photomicrographs of fuel rod 2-8-7. Irradiation condition $0.58 \times 10^{29} \mathrm{n} / \mathrm{cm}^{2}$ at $912^{\circ} \mathrm{C}$. (a) Typical appearance of matrix graphite. (b) Composite showing radial cross section 



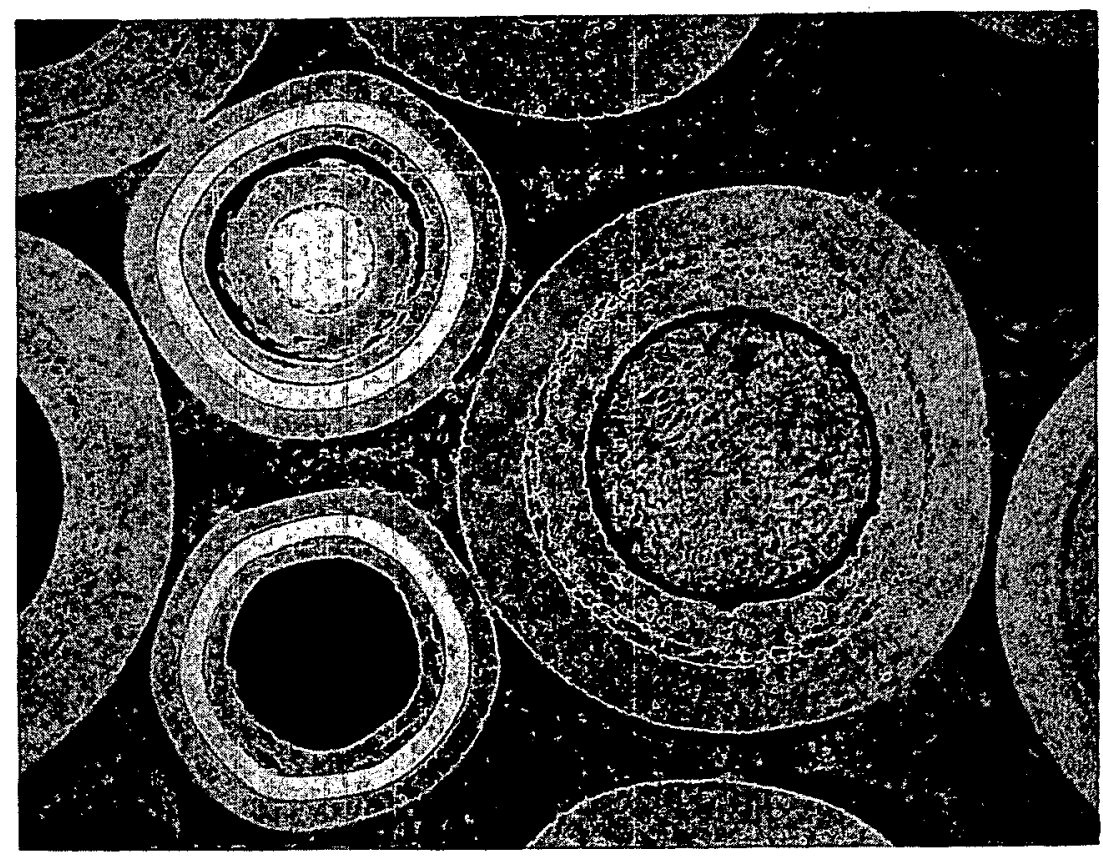

L7311-114

$100 \mathrm{X}$

Fig. 34. FTE-3 photomicrograph of representative particles from fuel rod 2-8-7. $\mathrm{UC}_{2}$ TRISO and $\mathrm{ThC}_{2}$ BISO particles after irradiated

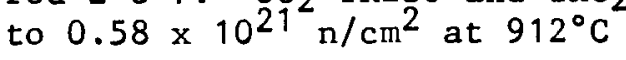




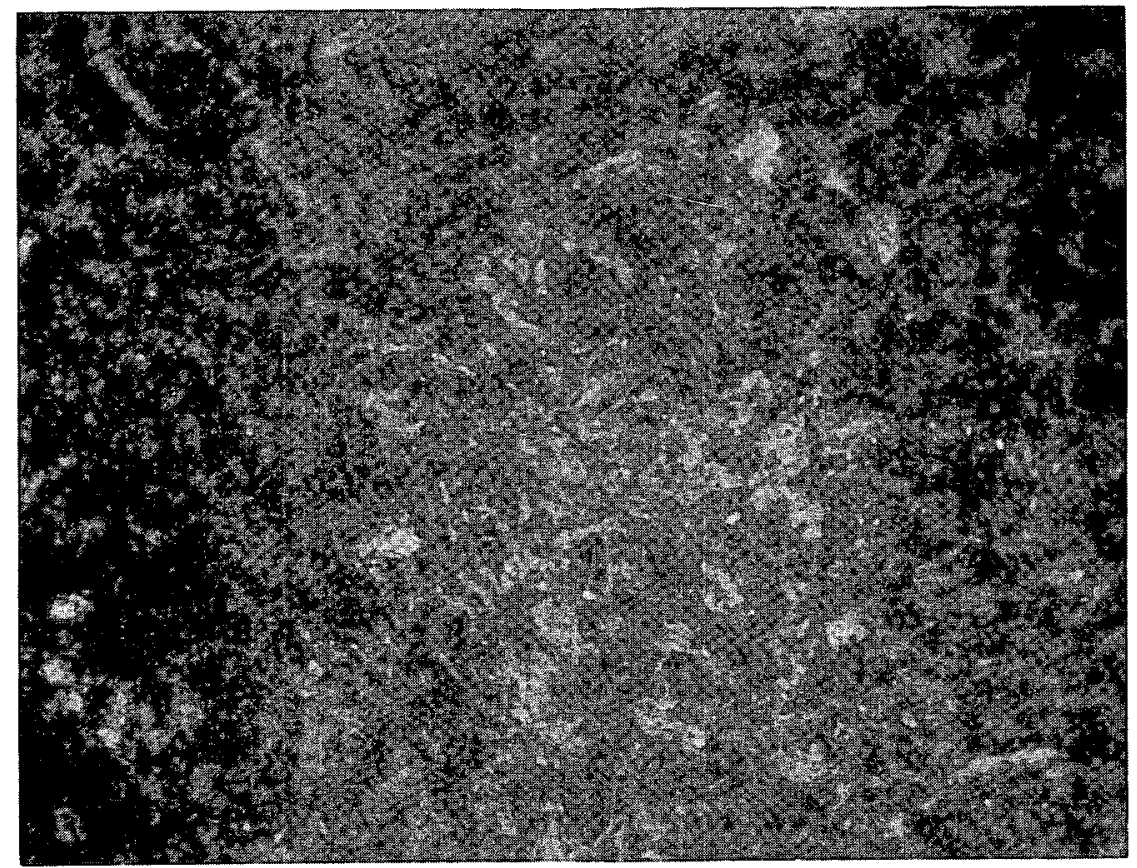

L7311-101

(a)

$650 \mathrm{x}$

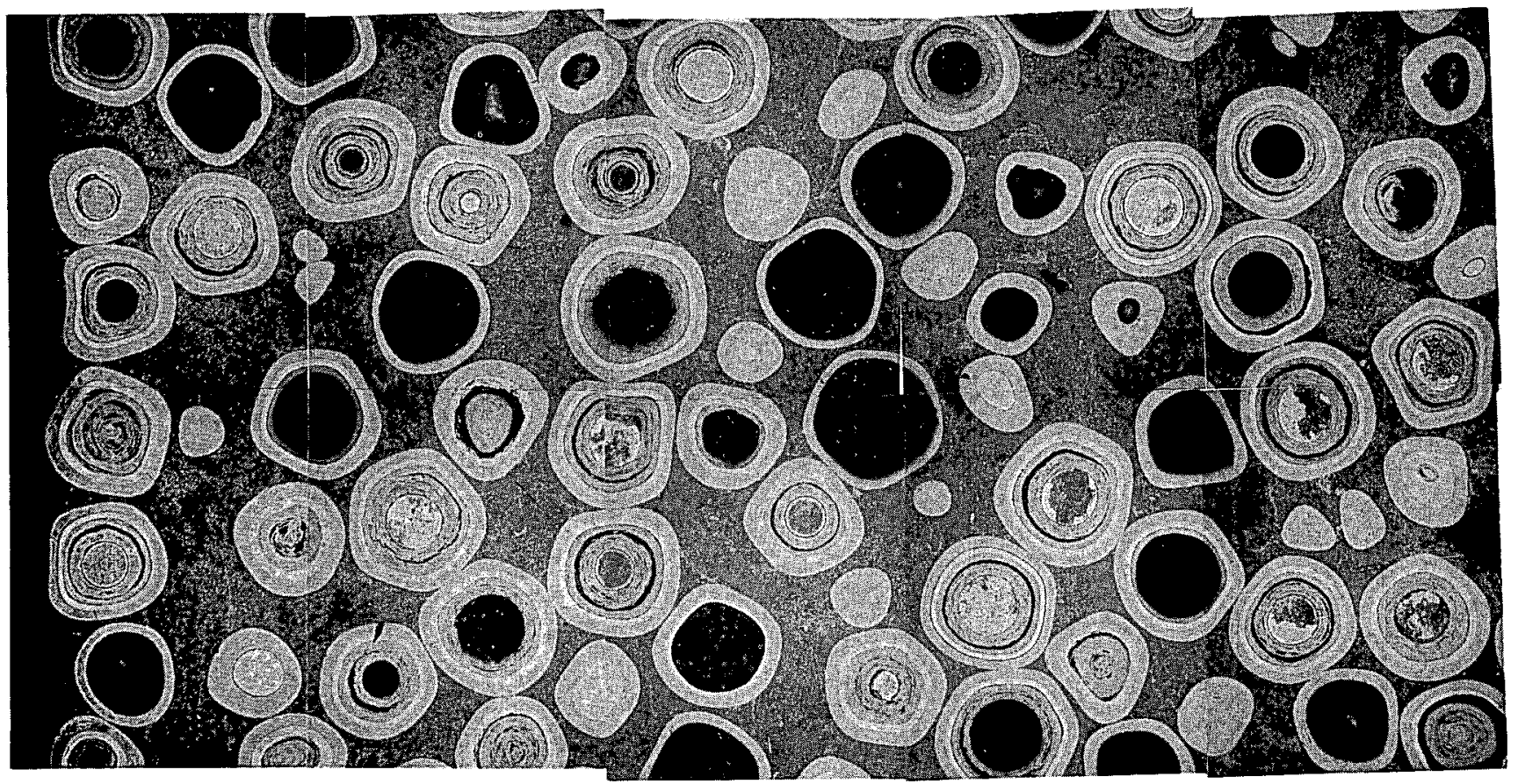

L7311 (87-96)

(b)

ح29X

Fig. 35. FTE-3 photomicrographs of fuel rod 2-5-7. Irradiation to $0.58 \mathrm{x}$

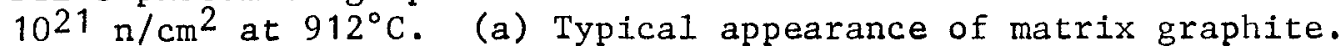
(b) Composite showing radial cross section 

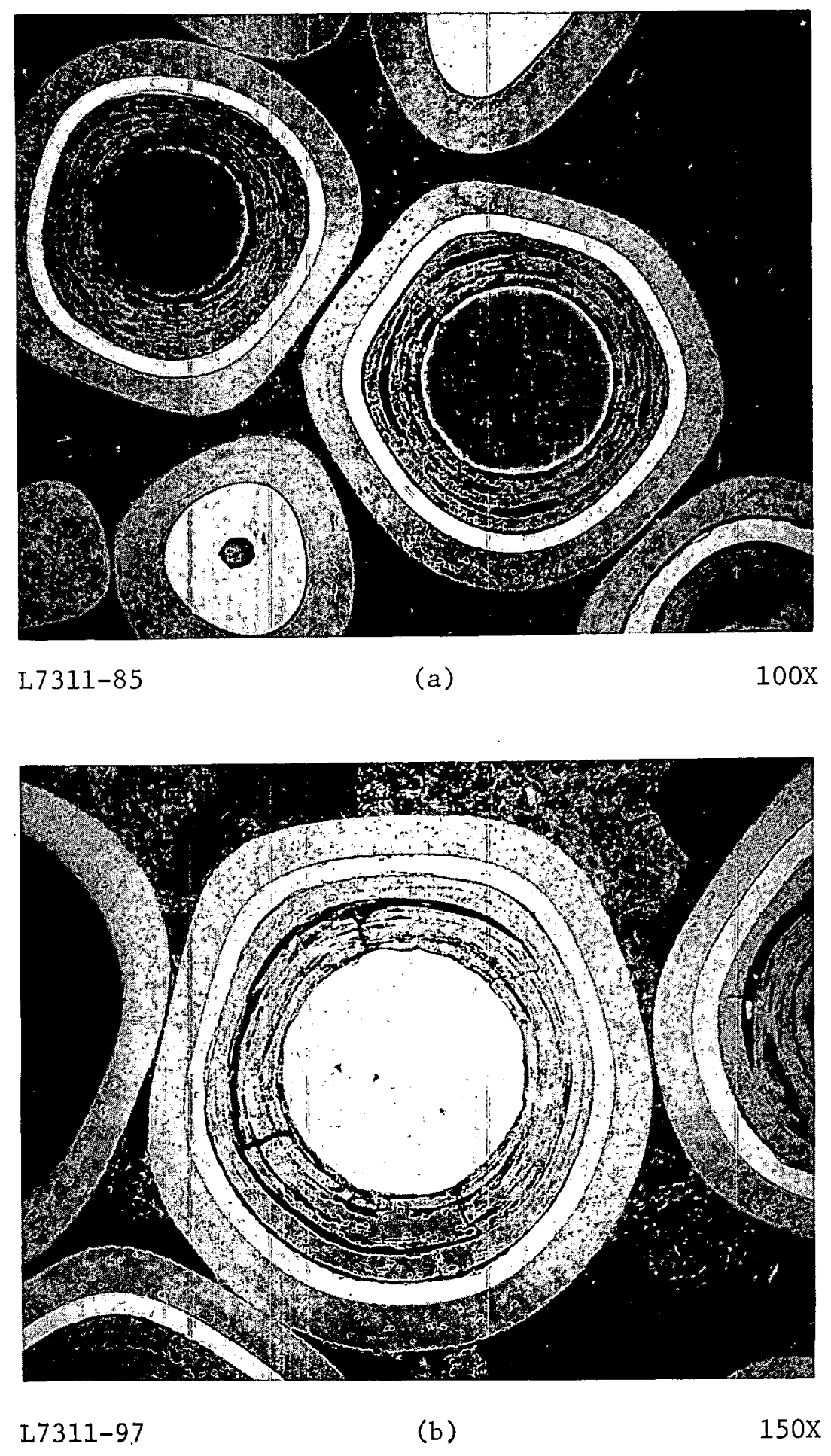

Fig. 36. FTE-3 photomicrographs of representative particles from fuel rod 2-5-7. Irradiation to $0.58 \times 10^{21} \mathrm{n} / \mathrm{cm}^{2}$ at $912^{\circ} \mathrm{C}$. (a) $(\mathrm{Th}, \mathrm{U}) \mathrm{C}_{2}$ TRISO particles. (b) $\mathrm{ThC}_{2}$ TRISO particle 


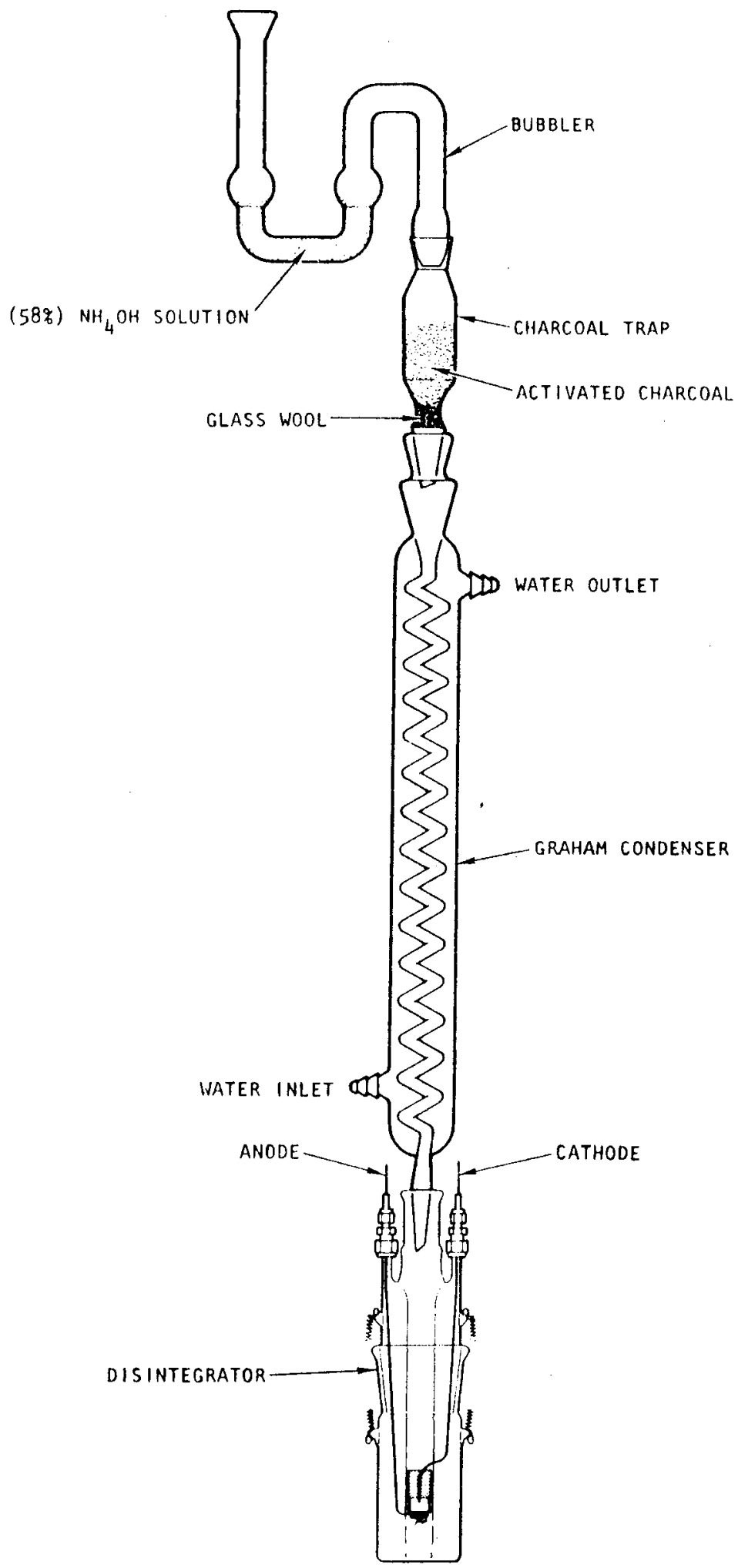

Fig. 37. Fuel rod disintegration unit for dissociation of irradiated fuel rods 


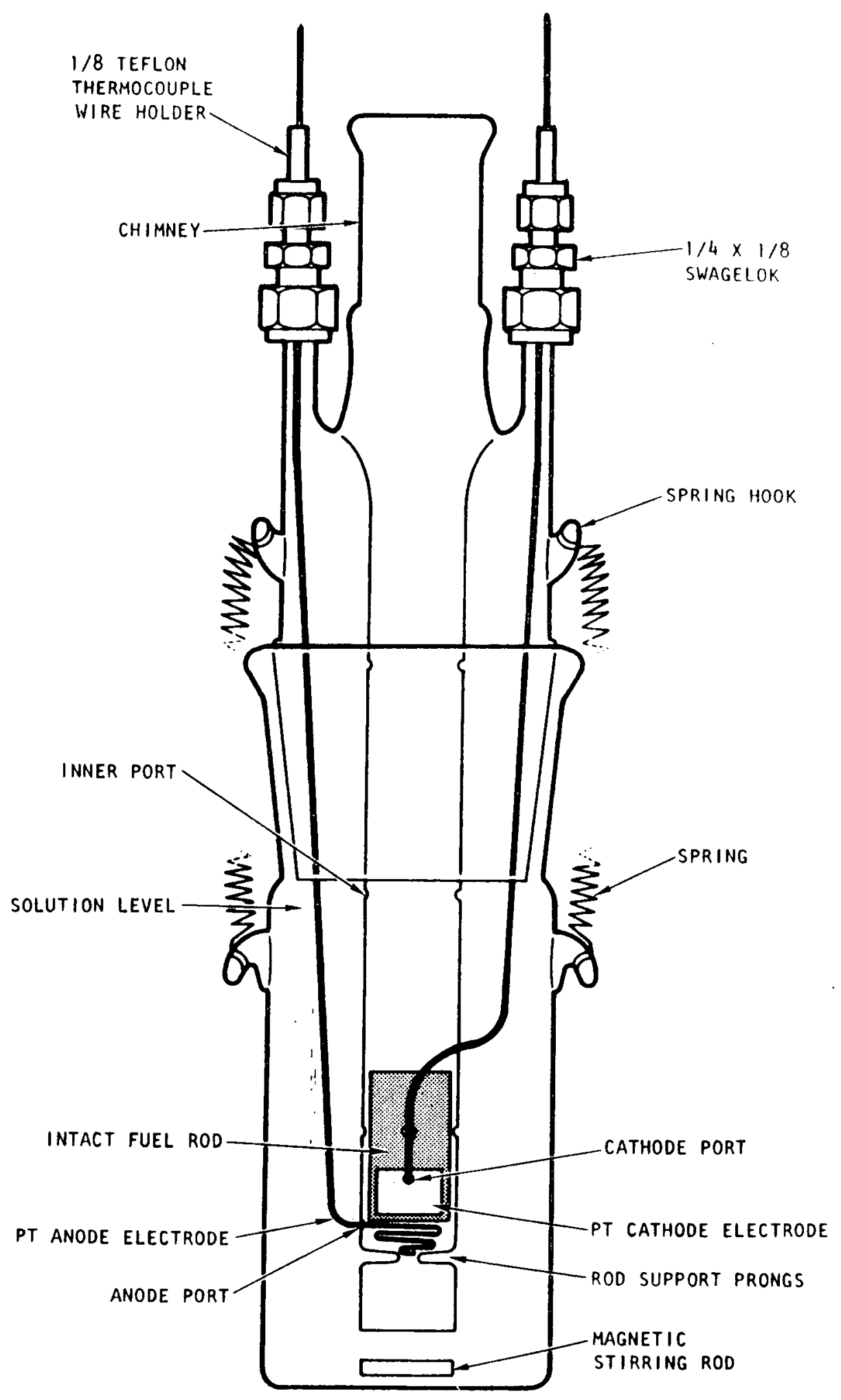

Fig. 38. Disintegration chamber for electrolytic dissociation of fuel rods in an acid medium 




S7311-34

4X

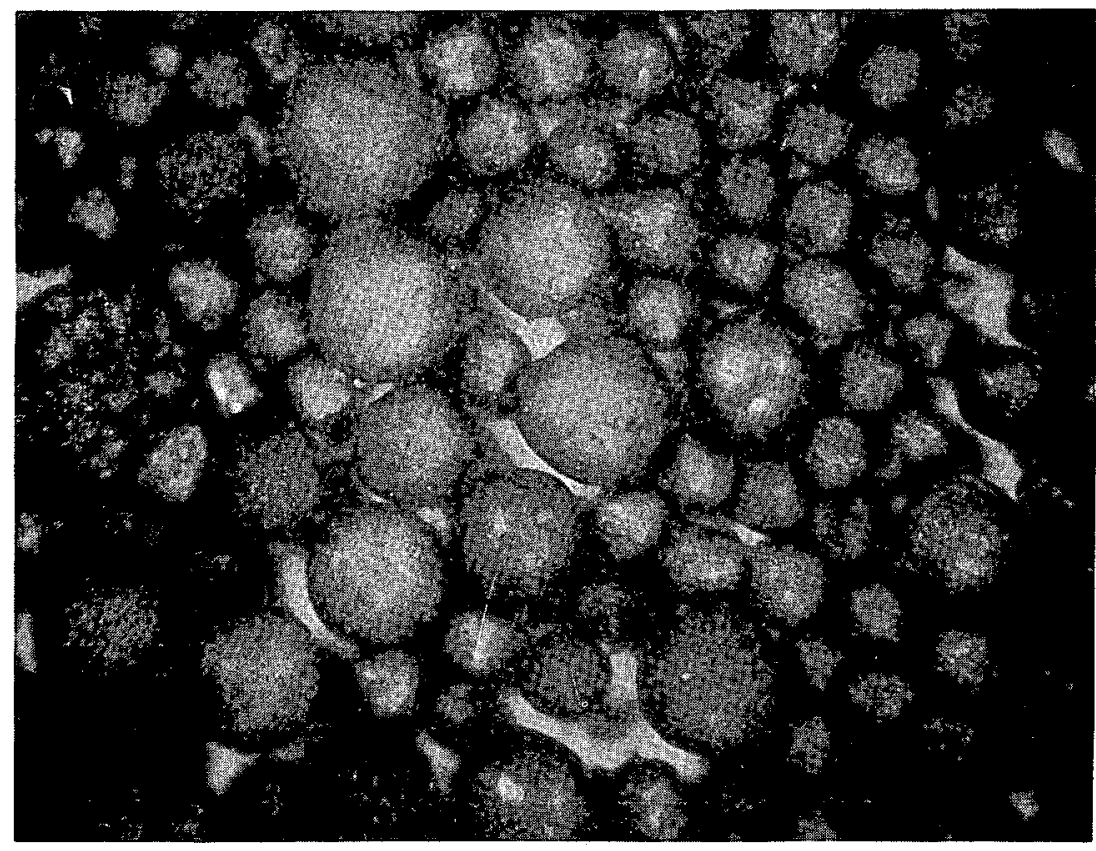

S7311-35

20X

Fig. 39. FTE-3 electrolytic disintegration of fuel rod 1-8-7. Photomicrographs of a portion of the fuel particles recovered from fuel rod $1-8-7$ after it was electrolytically disintegrated and acid-leached 


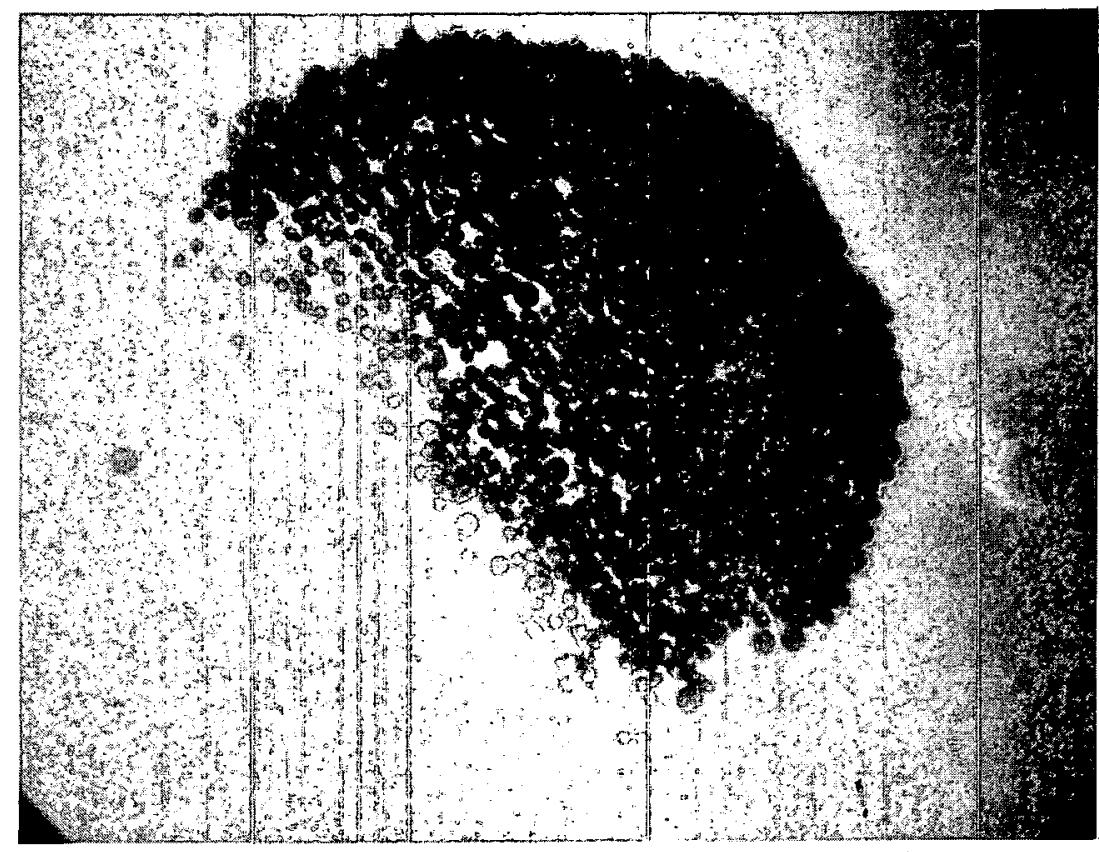

S7311-36

$4 \mathrm{X}$

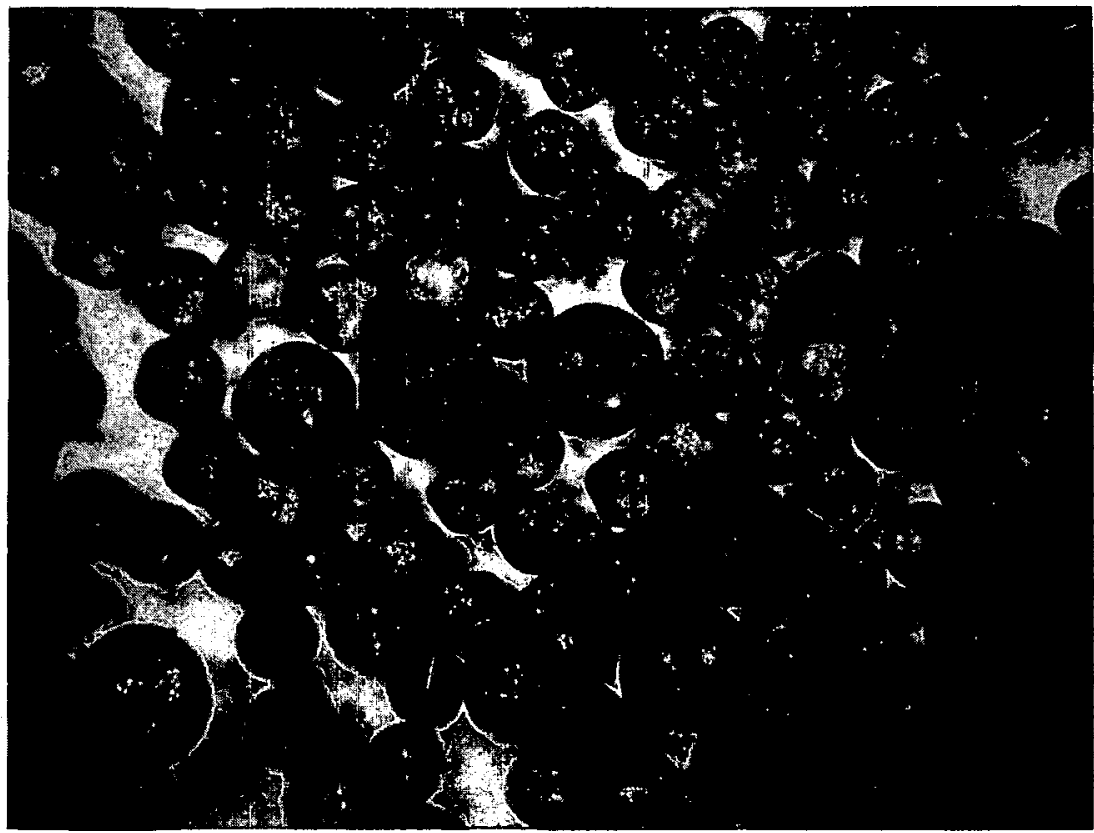

S7311-37

$20 \mathrm{X}$

Fig. 40. FTE-3 electrolytic disintegration of fuel rod 1-8-8. Photomicrographs of a portion of the fuel particles recovered from fuel rod 1-8-8 after it was electrolytically disintegrated and acid-leached 


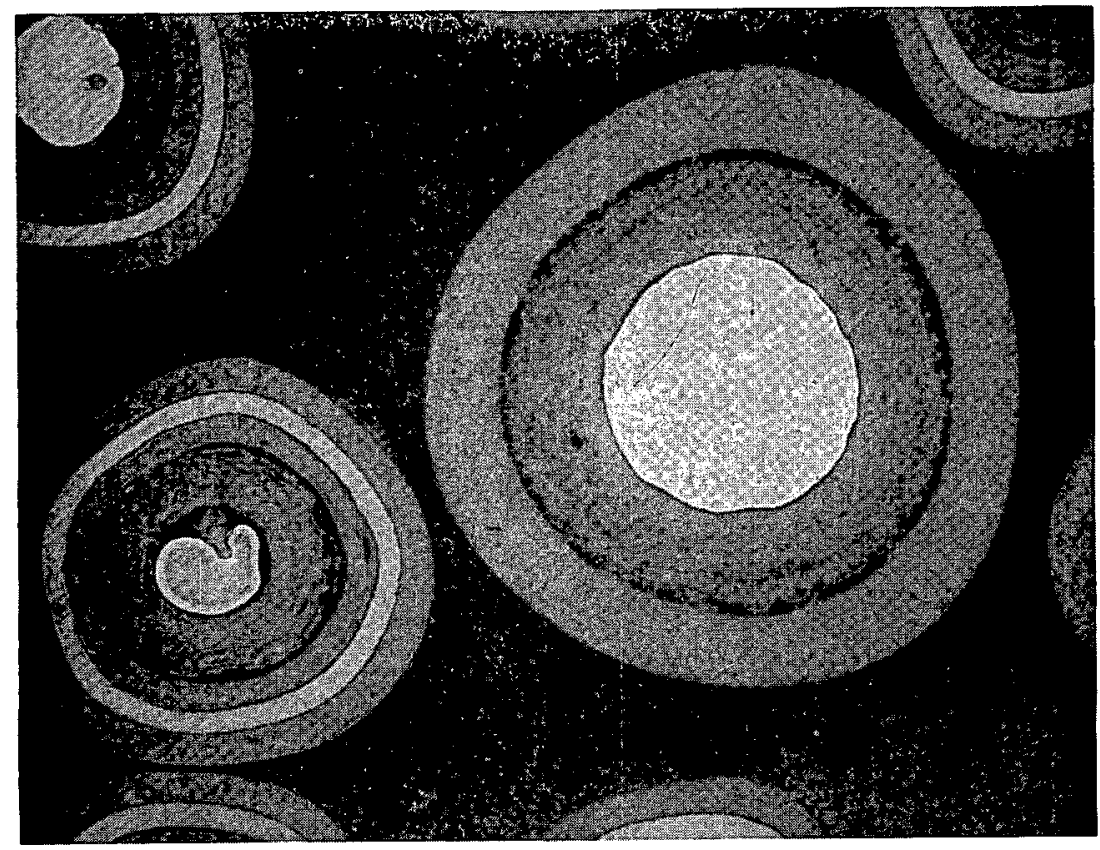

L7311-130

(a)

$100 \mathrm{X}$

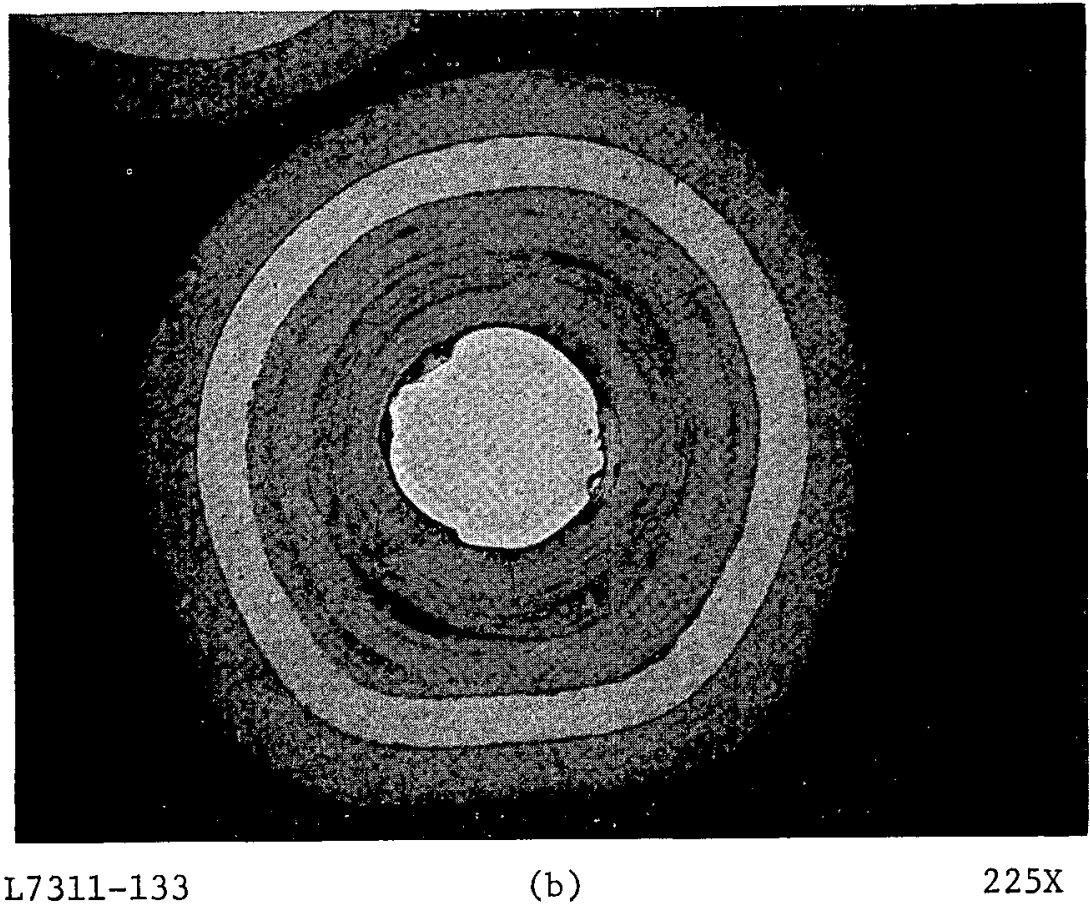

Fig. 41. FTE-3 metallography on fuel rod 1-8-7 particles after electrolytic disintegration. Photomicrographs of representative particles from fuel rod 1-8-7 after irradiation in FTE-3 to $0.50 \times 10^{21} \mathrm{n} / \mathrm{cm}^{2}$ at $751^{\circ} \mathrm{C}$. (a) $\mathrm{UC}_{2}$ TRISO and $\mathrm{ThC}_{2}$ BISO particles. (b) $\mathrm{UC}_{2}$ TRISO particle. Metallographic examination was conducted after the fuel rod was electrolytically disintegrated and acid-1eached. 


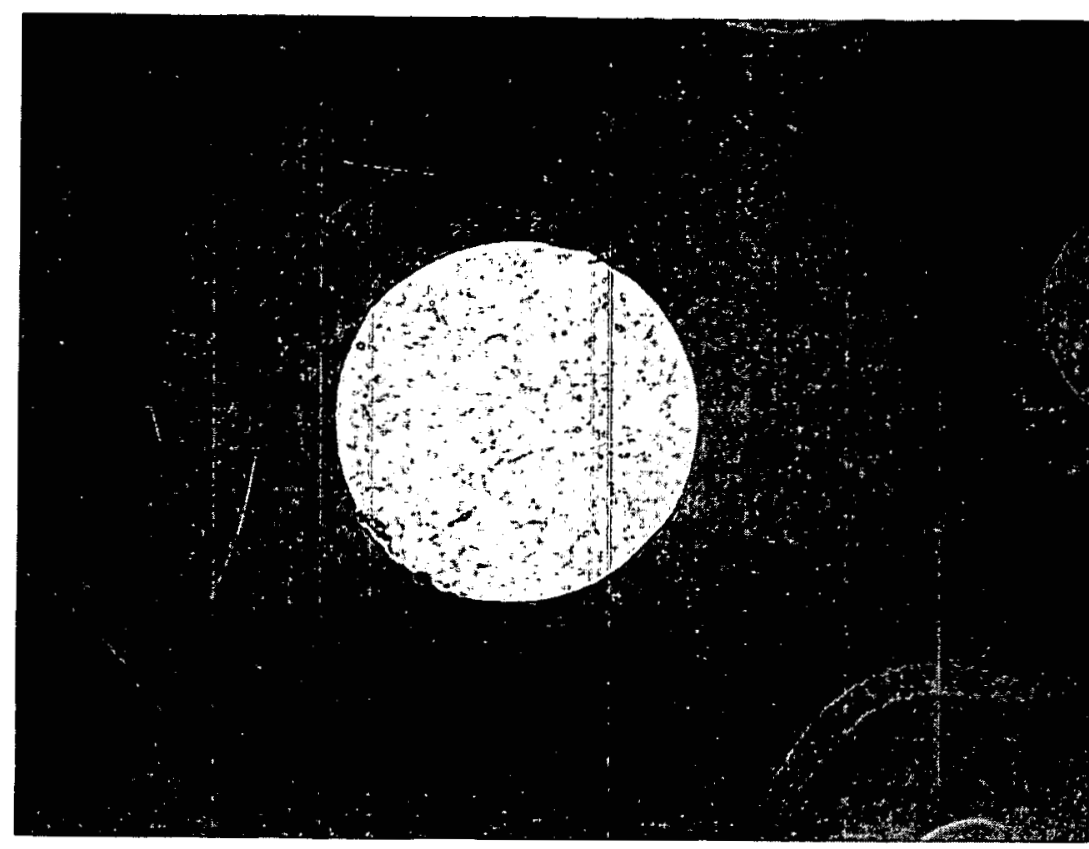

L7311-136

(a)

$150 \mathrm{x}$

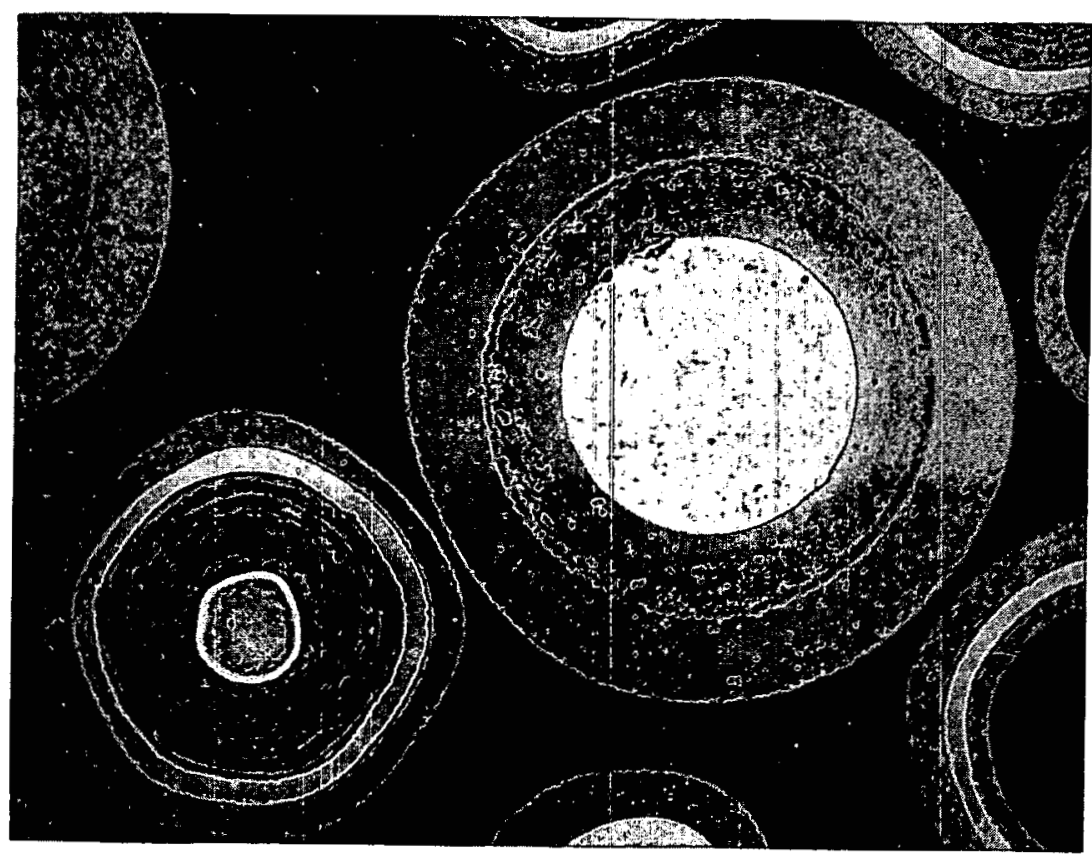

L7311-138

(b)

$115 \mathrm{X}$

Fig. 42. FTE-3 metallography on fuel rod 1-8-8 particles after electrolytic disintegration. Photomicrographs of representative particles from fuel rod $1-8-8$ after irradiation to $0.50 \times 10^{21} \mathrm{n} / \mathrm{cm}^{2}$ at $751^{\circ} \mathrm{C}$. (a) $\mathrm{ThC}_{2}$ BISO particle. (b) $\mathrm{UC}_{2}$ TRISO and $\mathrm{ThC}_{2}$ BISO particles. Metallographic examination was conducted after the fuel rod was electrolytically disintegrated and acid-leached. 


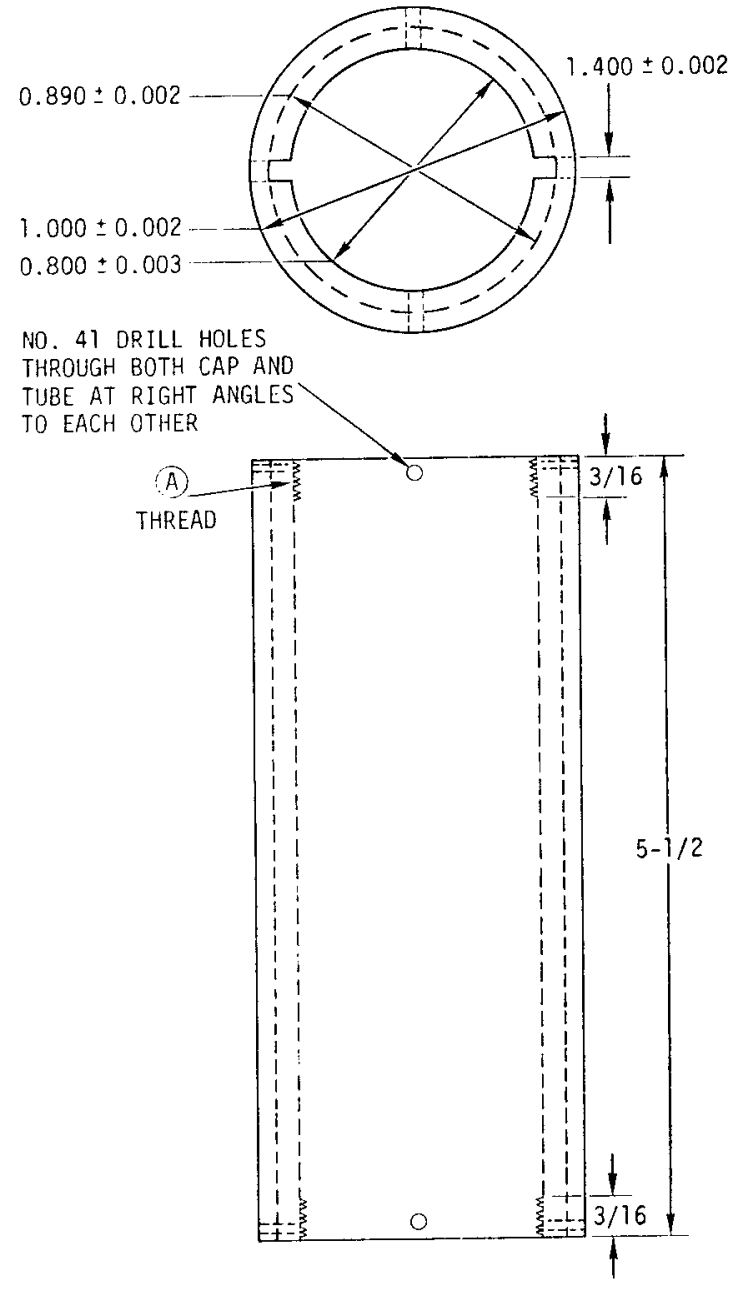

MATERIAL: $\quad H-327$ GRAPHITE

ALL DIMENSIONS IN INCHES
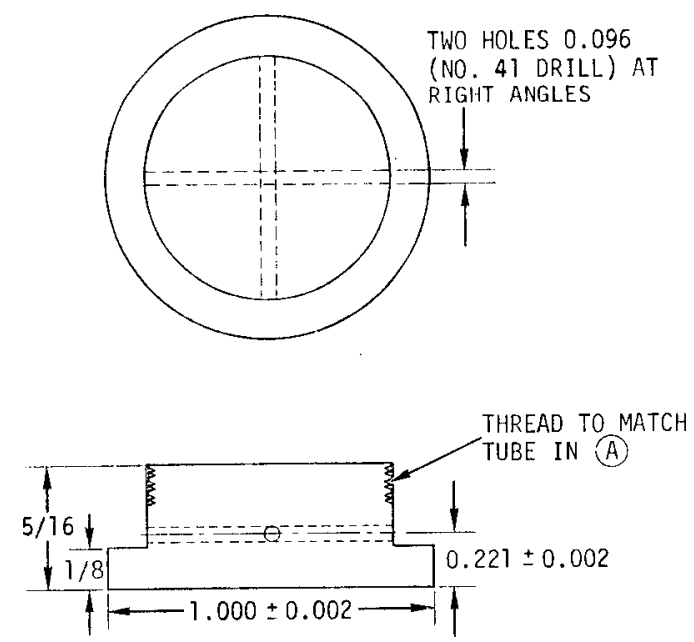

Fig. 43. Design of type 1 thermal stability outer crucibles 

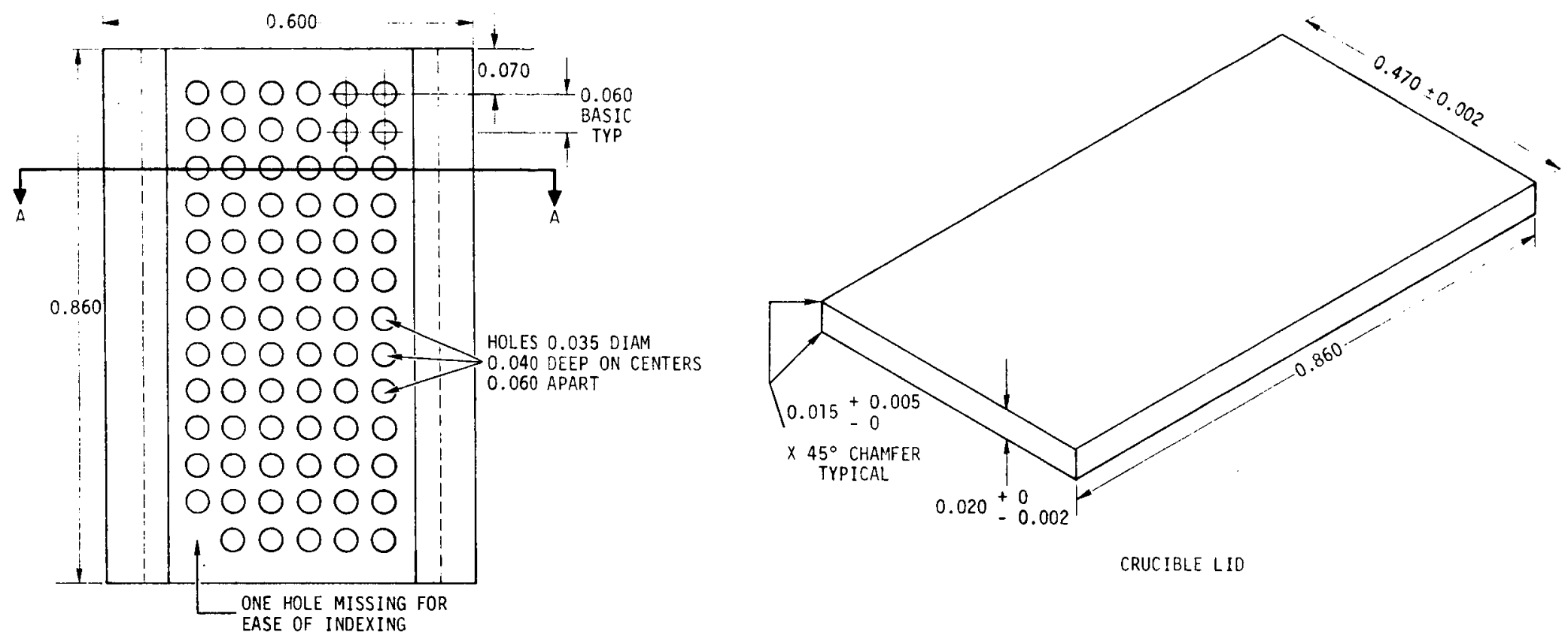

CRUCIBLE LIO

ONE HOLE MISSING
EASE OF INDEXING

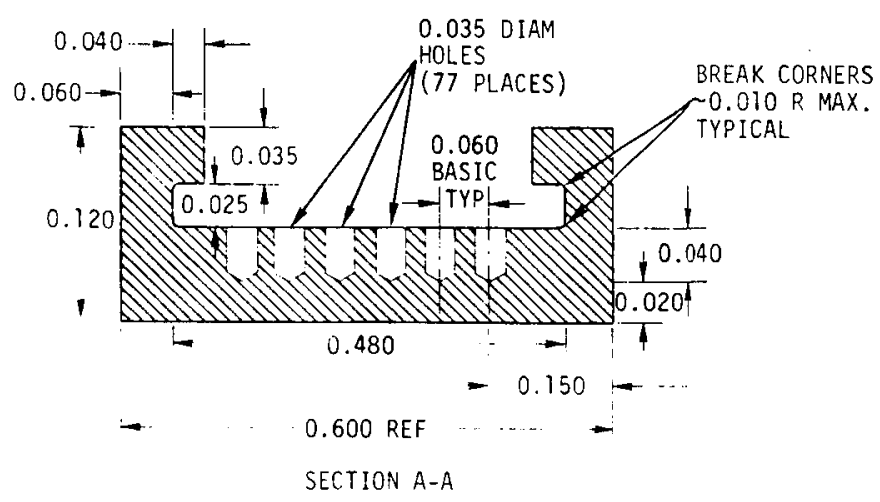

NOTES:

MATERIAL: HLM-85 OR ATJ GRAPHITE FOR ALL PARTS.

S

SECTION A-A

Fig. 44. Design of type 1 thermal stability inner crucibles 

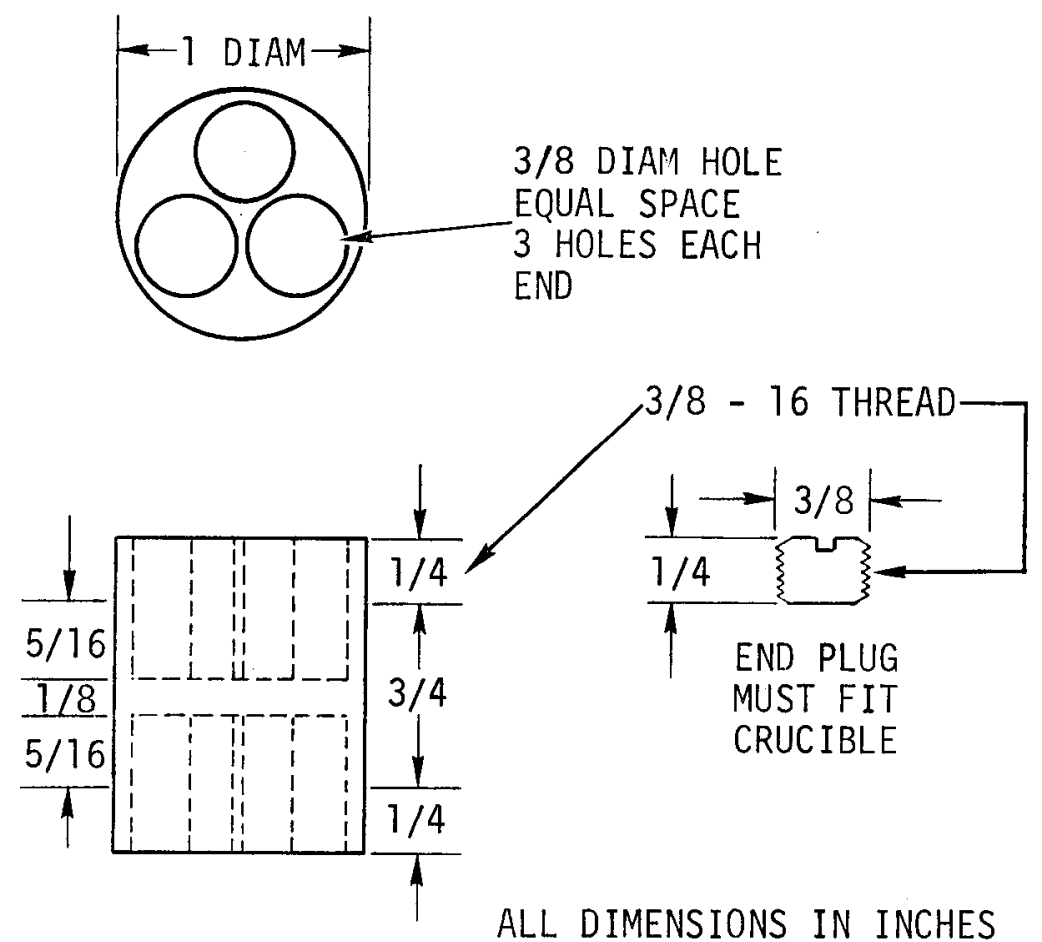

MATERIAL : AGOT GRAPHITE

Fig. 45. Design of type 2 thermal stability crucibles 


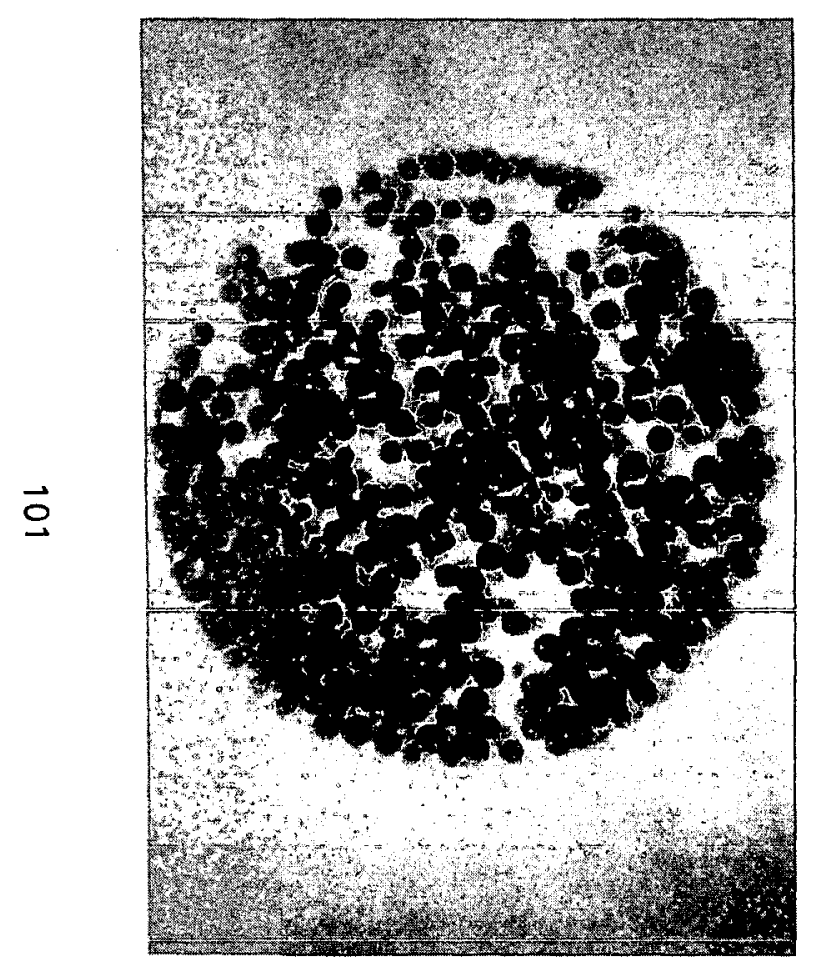

S7339-1

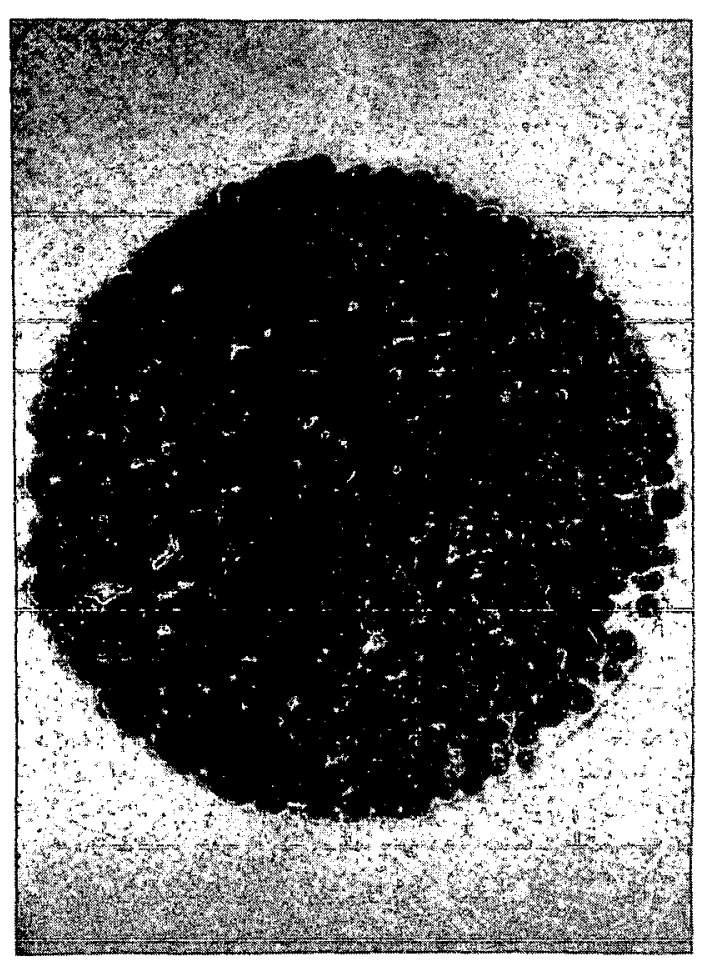

S7339-3

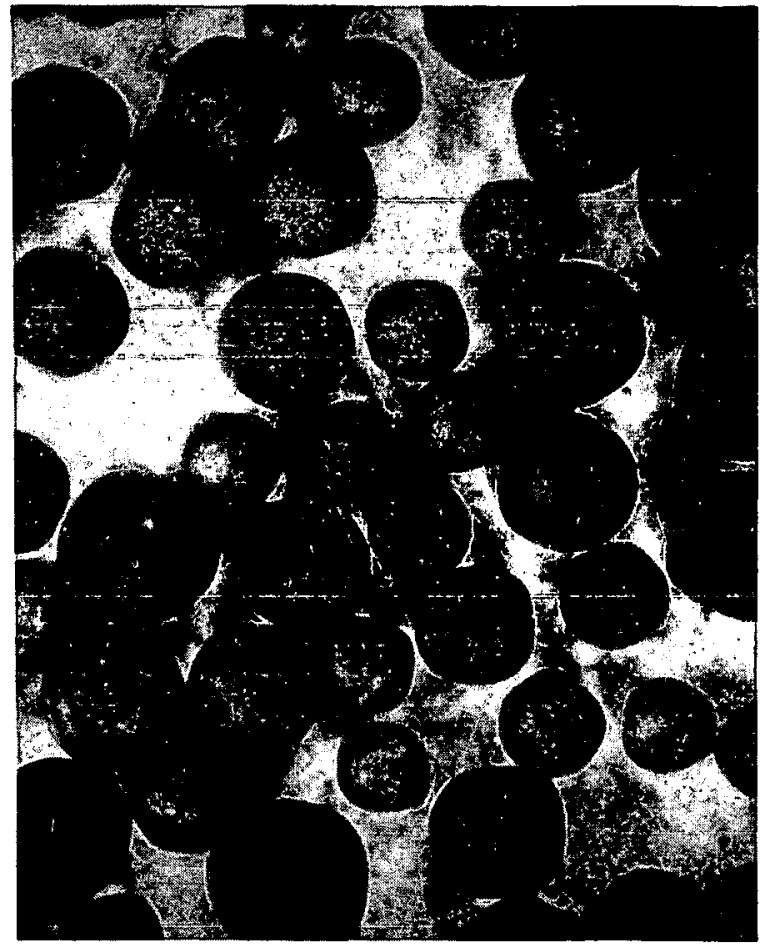

S7339-2

Fig. 46. FTE-3 thermal stability spine sample $\mathrm{K}$, visual examination. Representative photographs taken during the visual examination of TRISO-coated fissile and fertile driver fuel from crucible $\mathrm{K}$. No OPyC coating failure was observed. 


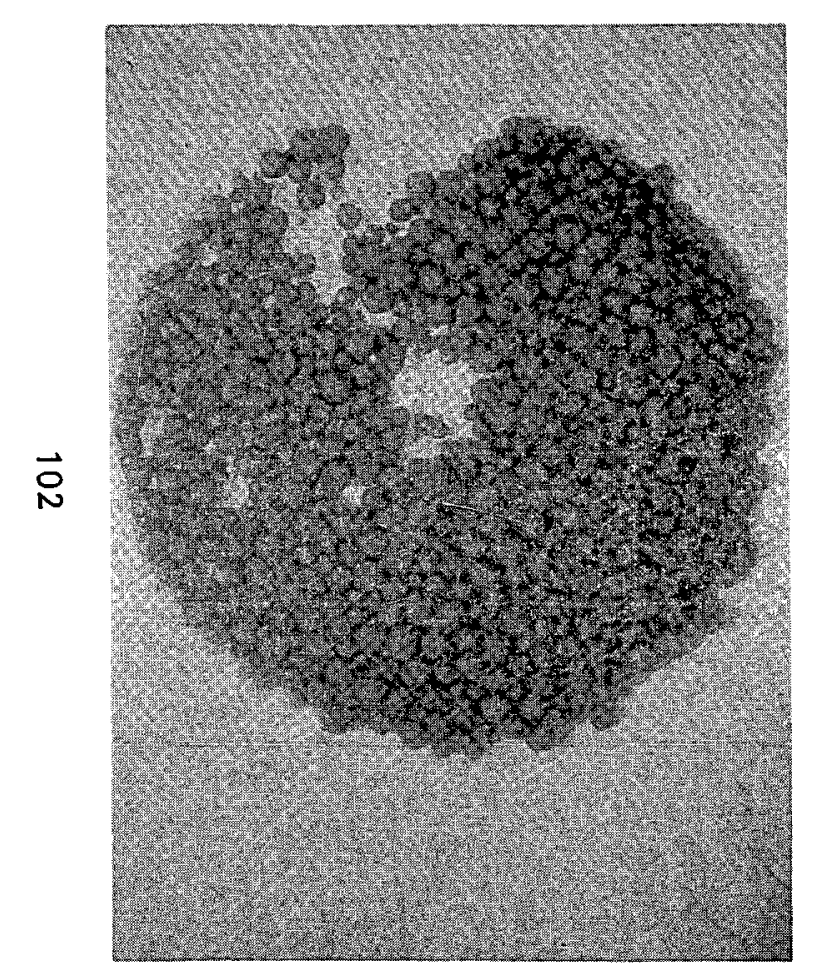

S7339-5

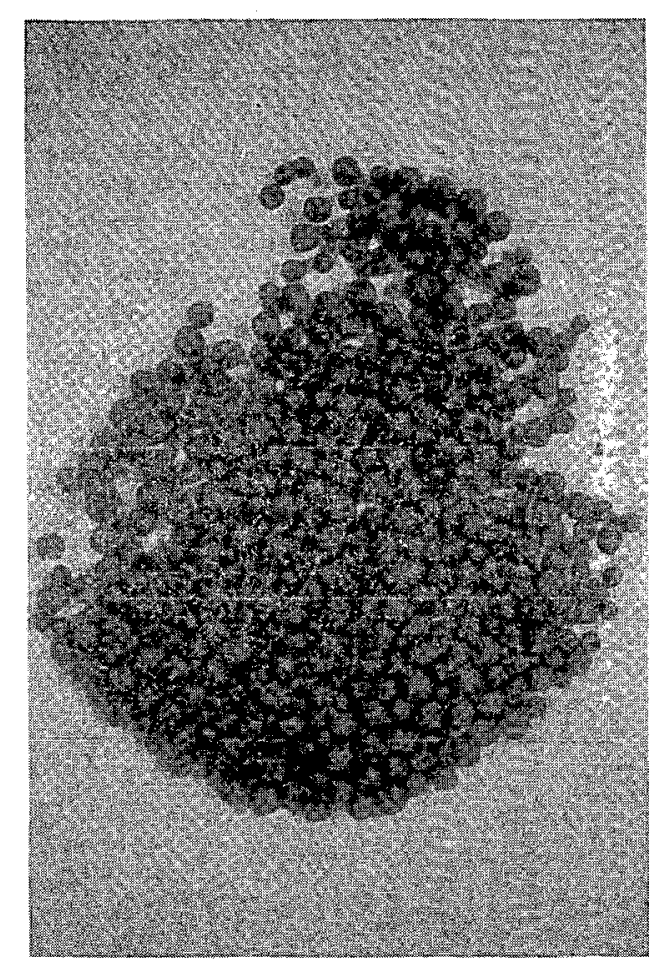

$57339-4$

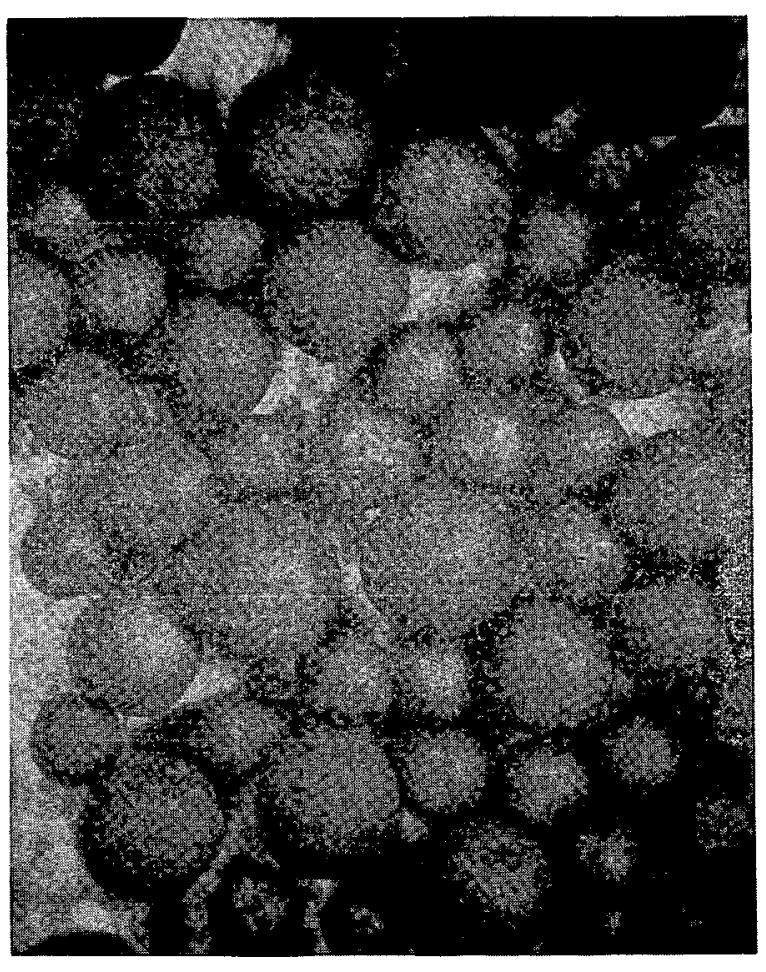

S7339-6

Fig. 47. FTE-3 thermal stability spine sample I, visual examination. Representative photographs taken during the visual examination of TRISO-coated fissile and fertile driver fuel from crucible L. No OPyC coating failure was observed. 


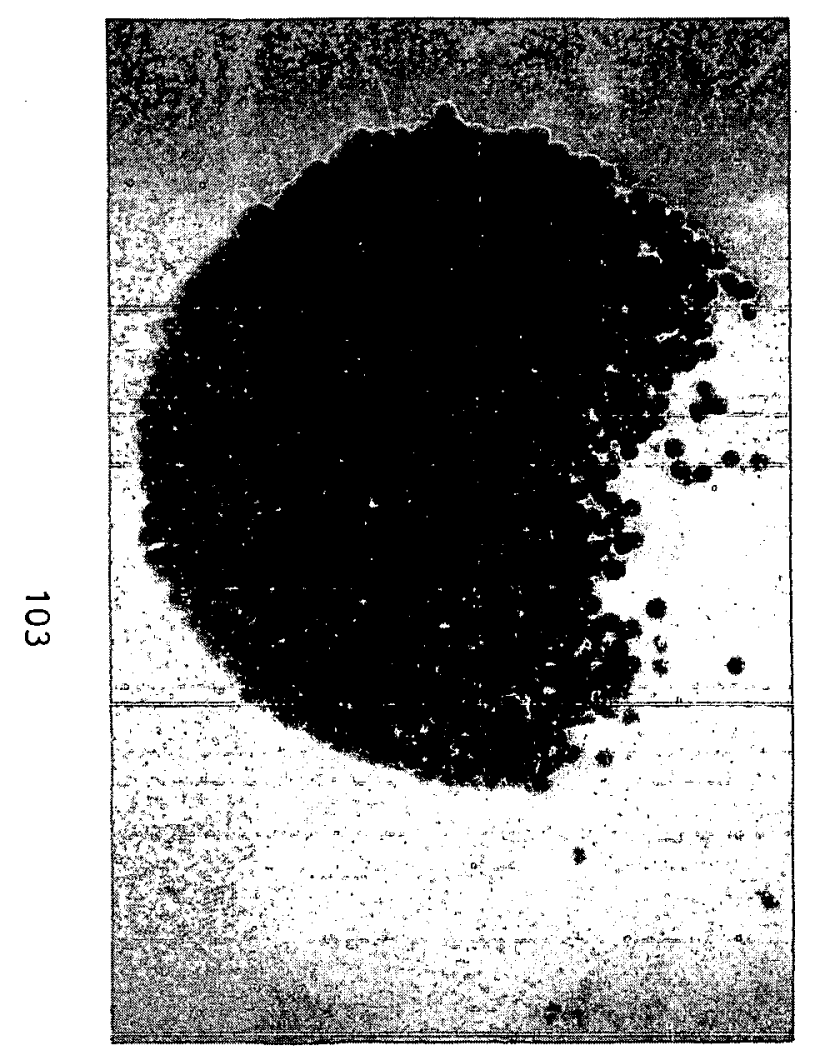

57339-7

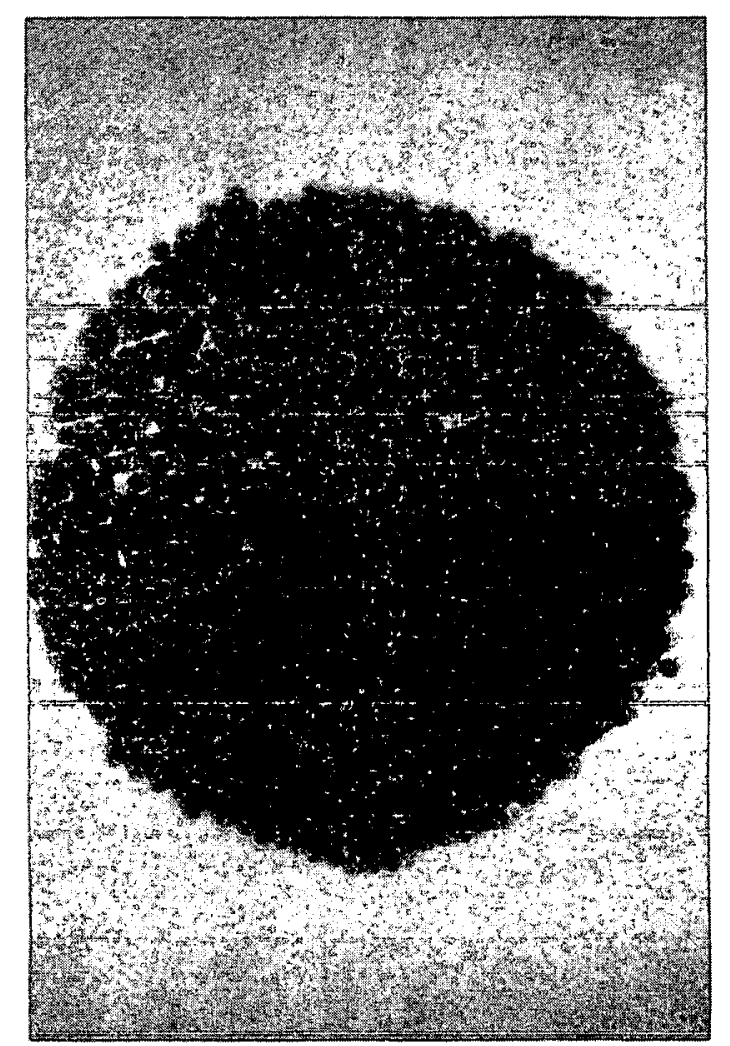

S7339-9

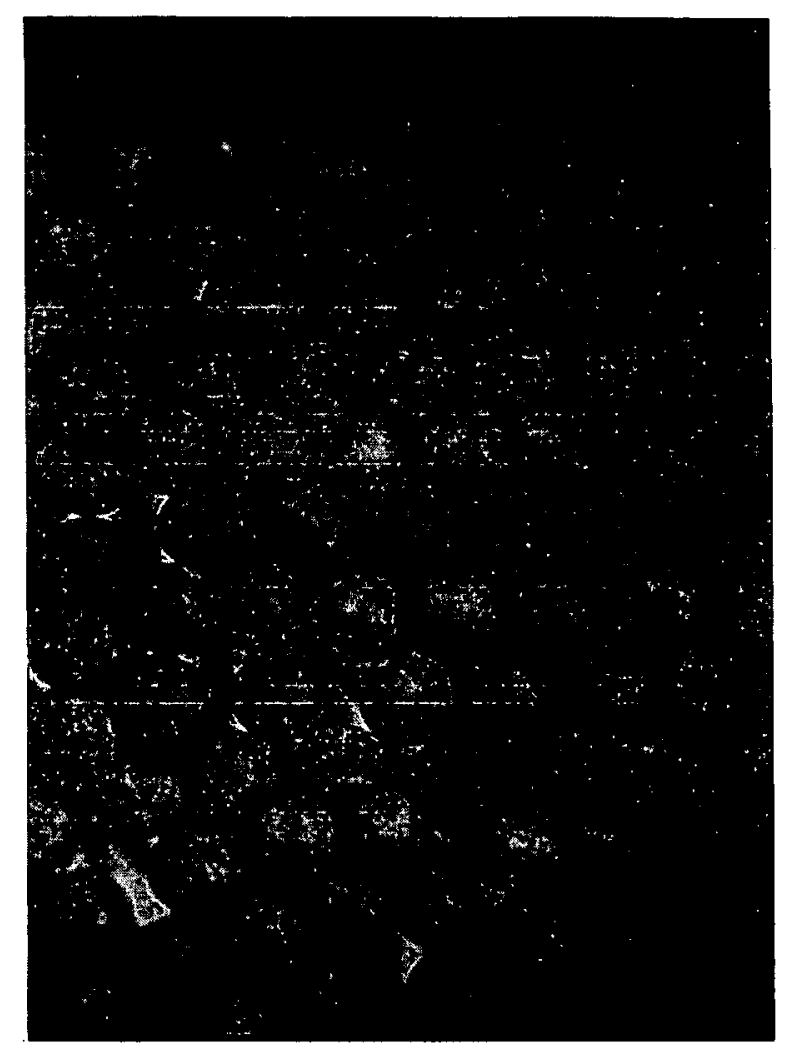

S7339-8

Fig. 48. FTE-3 thermal stability spine sample 5, visual examination. Representative photographs taken during the visual example of $\mathrm{UO}_{2}$ particles (Batch No. 4503-59) irradiated in crucible $5-6$ to $20.32 \times 10^{21} \mathrm{n} / \mathrm{cm}^{2}$ at $\sim 823^{\circ} \mathrm{C}$. 


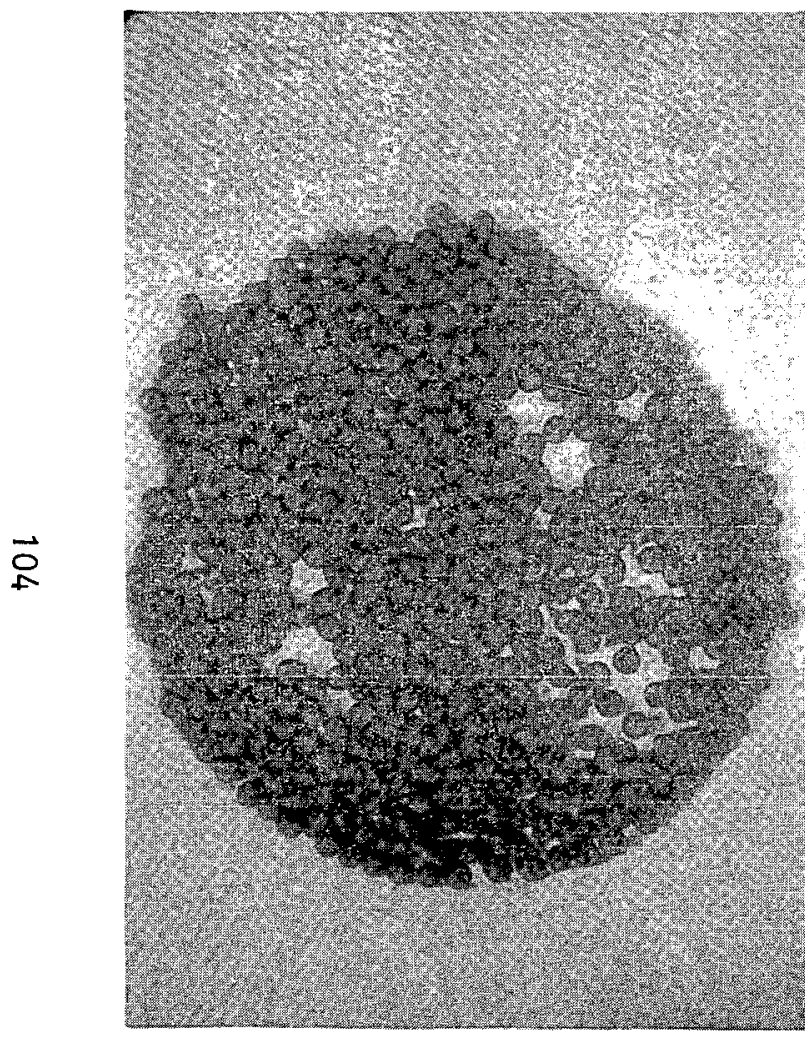

S7339-13

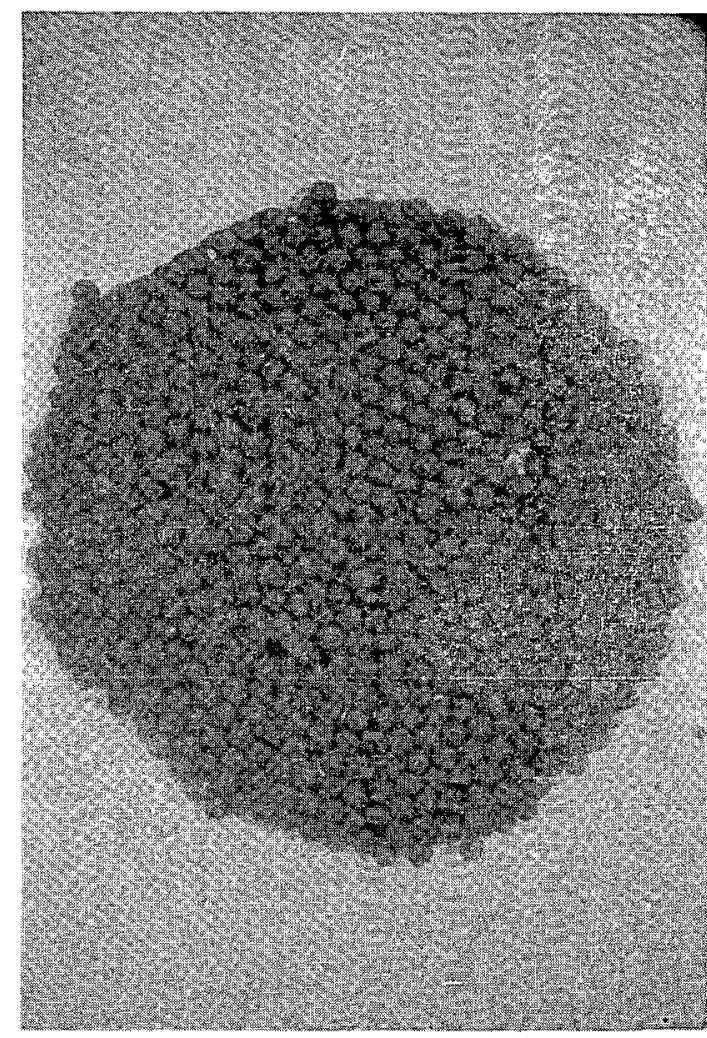

S7339-15

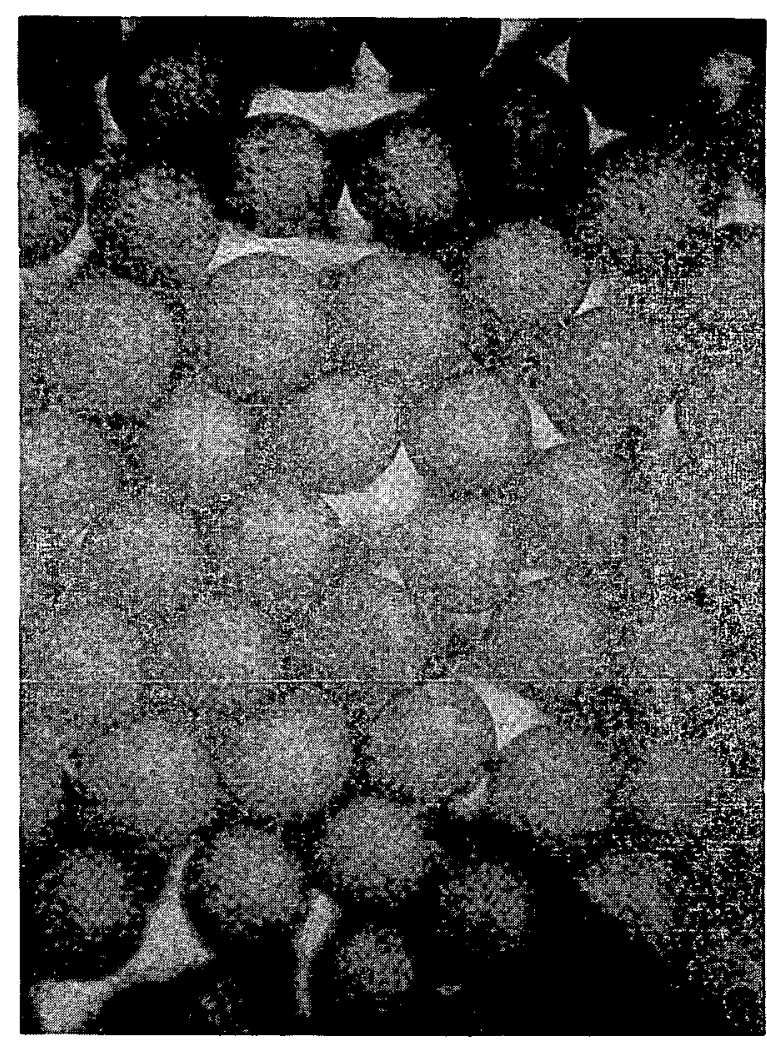

S7339-14

Fig. 49. FTE-3 thermal stability spine sample 17, visual examination. Representative photographs taken during the visual examination of $\mathrm{ThO}_{2}$ BISO particles (Batch No. 4493-149) irradiated in crucible $17-6$ to $20.38 \times 10^{21} \mathrm{n} / \mathrm{cm}^{2}$ at $\sim 839^{\circ} \mathrm{C}$. 

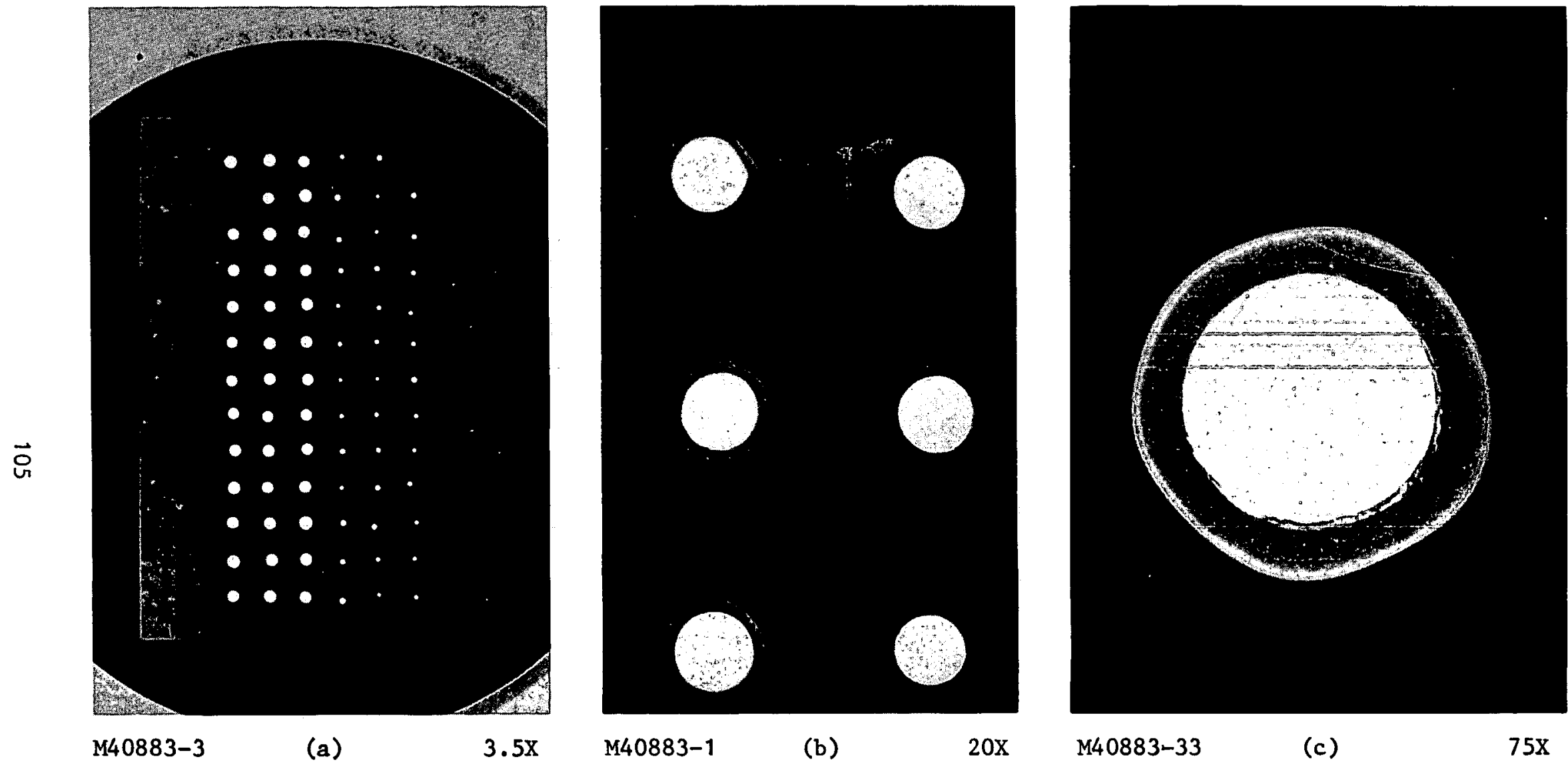

Fig. 50. FTE-3 thermal stability spine sample L, microradiographs. Photographs of contact microradiograph taken of crucible 86 irradiated to $20.40 \times 10^{21} \mathrm{n} / \mathrm{cm}^{2}$ at $\sim 851^{\circ} \mathrm{C}$ : (a) shows entire crucible, which contained TRISO $\mathrm{ThC}_{2}$ (400-195) and TRISO (Th,U) $\mathrm{C}_{2}$ (3592-35) particles, (b) and (c) photographs of the TRISO-coated $\mathrm{ThC}_{2}$ particles. 


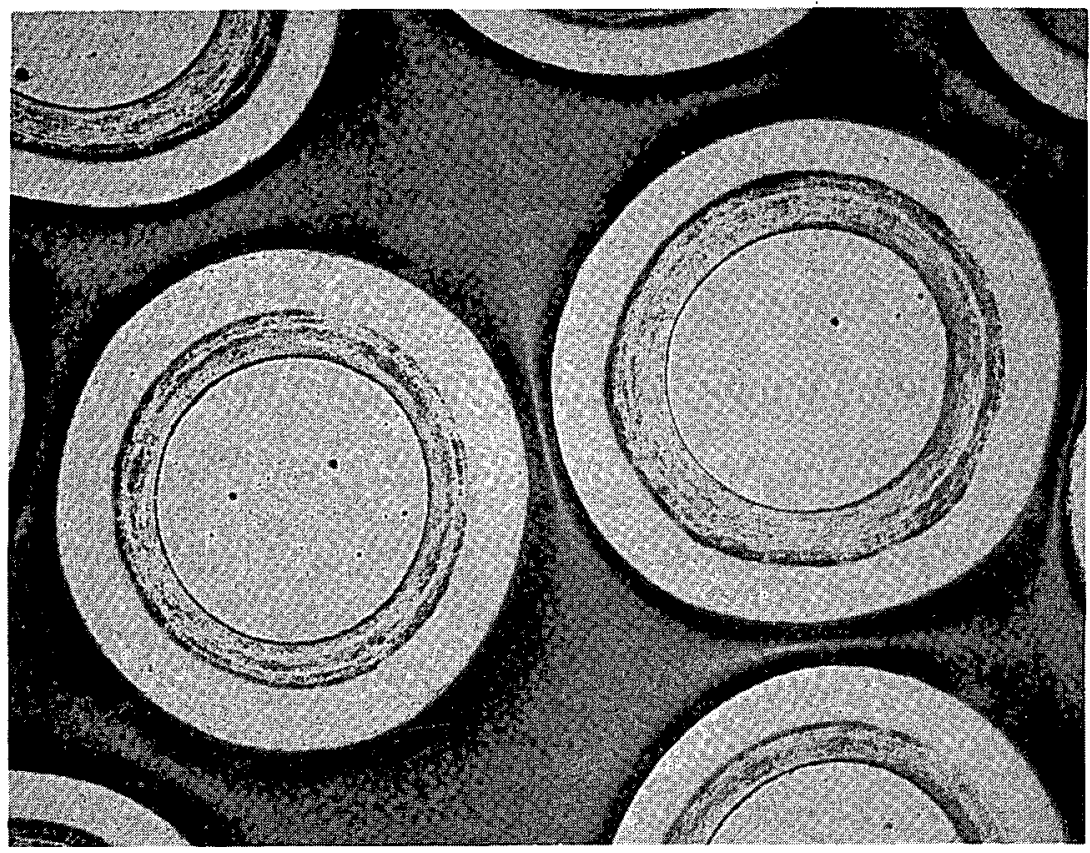

L7311-236

(a)

$80 \mathrm{X}$

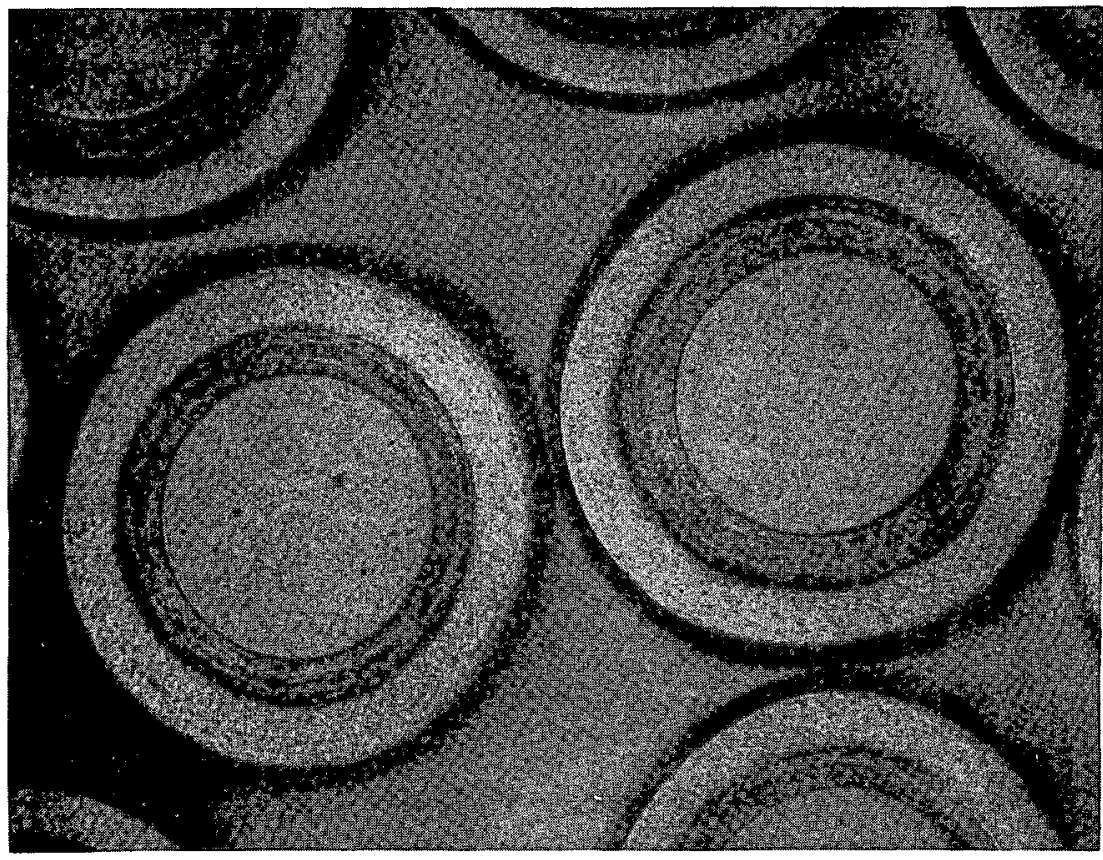

L7311-237

(b)

$80 \mathrm{X}$

Fig. 51. FTE-3 thermal stability spine sample 17, metallography. Representative photomicrographs of BISO-coated $\mathrm{ThO}_{2}$ particles (Batch No. 4493-149) irradiated in crucible $17-6$ to $20.38 \times 10^{21} \mathrm{n} / \mathrm{cm}^{2}$ at $2839^{\circ} \mathrm{C}:$ (a) bright field and (b) polarized light 

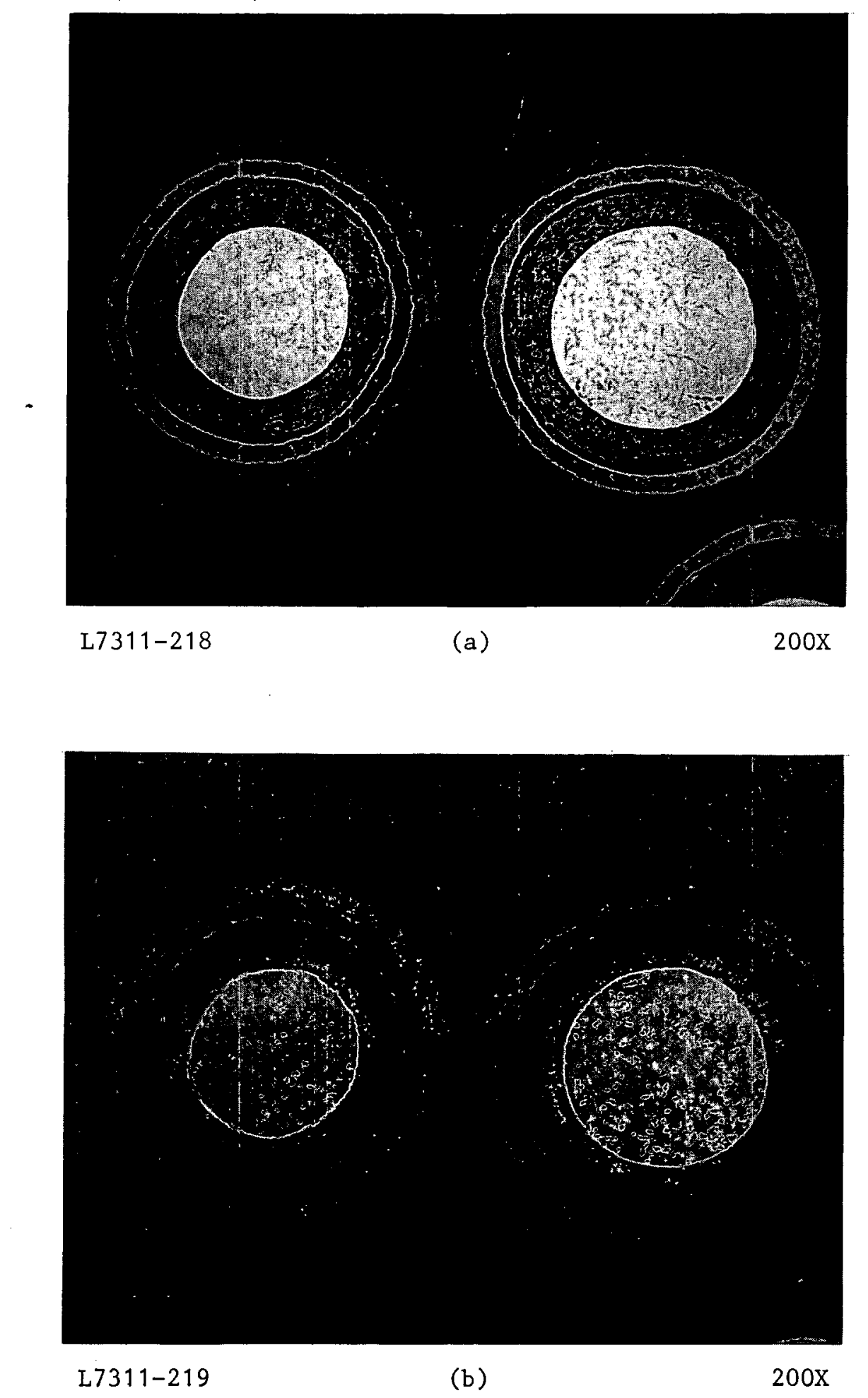

Fig. 52. FTE-3 thermal stability spine sample 29-3, metallography. Representative photomicrographs of TRISO-coated (Th,U) $\mathrm{C}_{2}$ particles (Batch No. 3592-35) irradiated in crucible 29-3 to $0.34 \times 10^{21}$ $\mathrm{n} / \mathrm{cm}^{2}$ at $\sim 829^{\circ} \mathrm{C}$ : (a) bright field and (b) polarized 1 ight. 


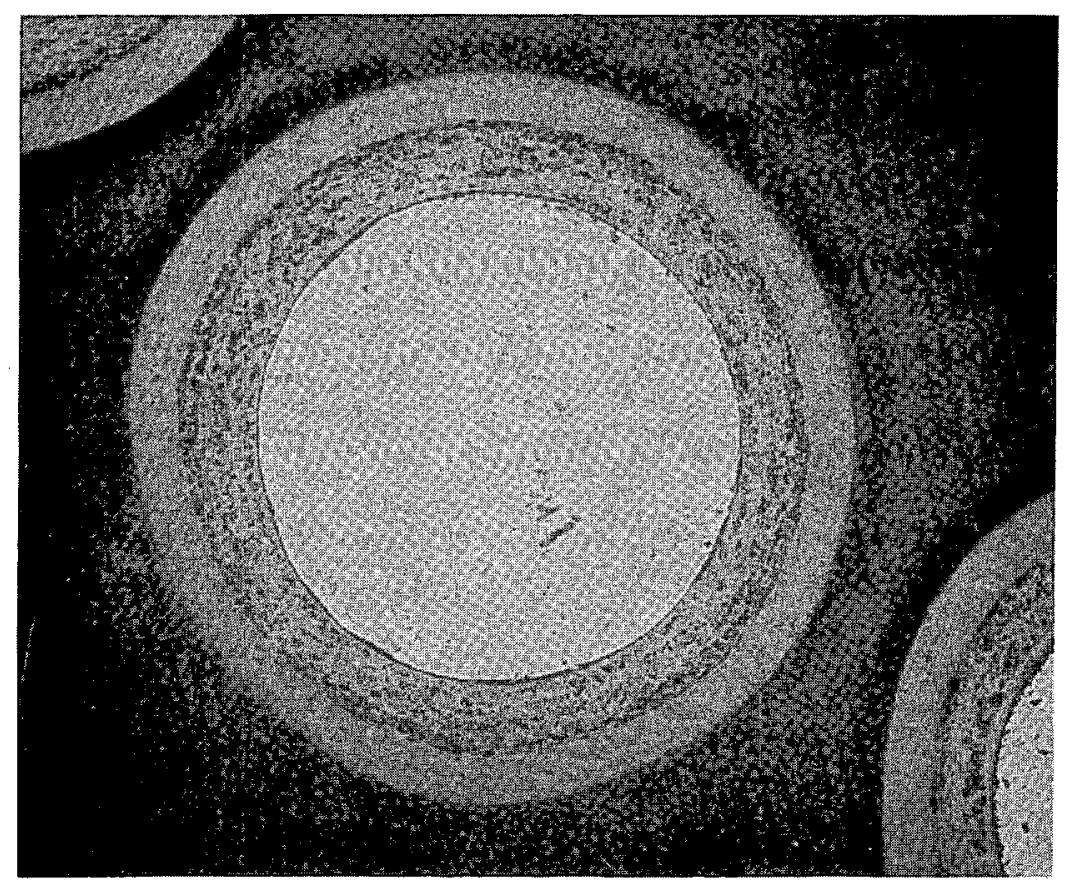

L7311-188

(a)

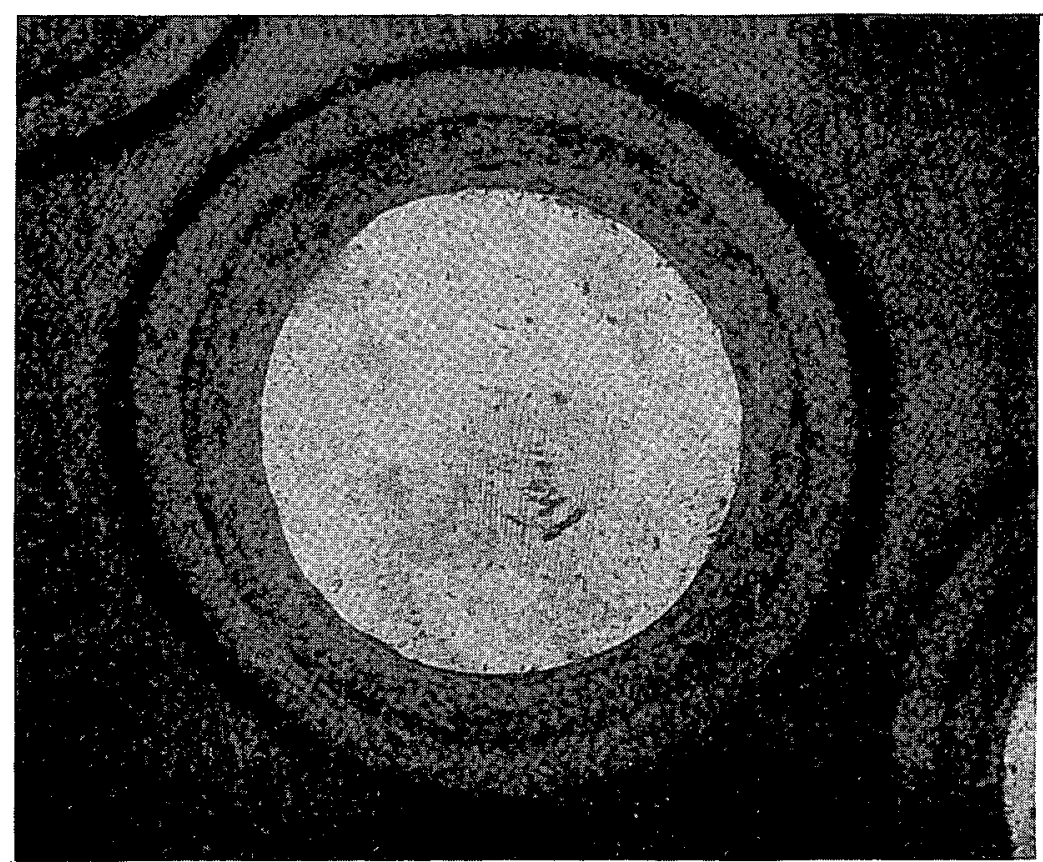

L7311-189

(b)

$80 \mathrm{X}$

Fig. 53. FTE-3 thermal stability spine sample 29-2, metallography. Representative photomicrographs of a BISO-coated $\mathrm{ThC}_{2}$ particle (Batch 4413-127) irradiated in crucible 29-2 to $00.34 \times 10^{21}$ $\mathrm{n} / \mathrm{cm}^{2}$ at $\sim 829^{\circ} \mathrm{C}$ : (a) bright field and (b) polarized light. 


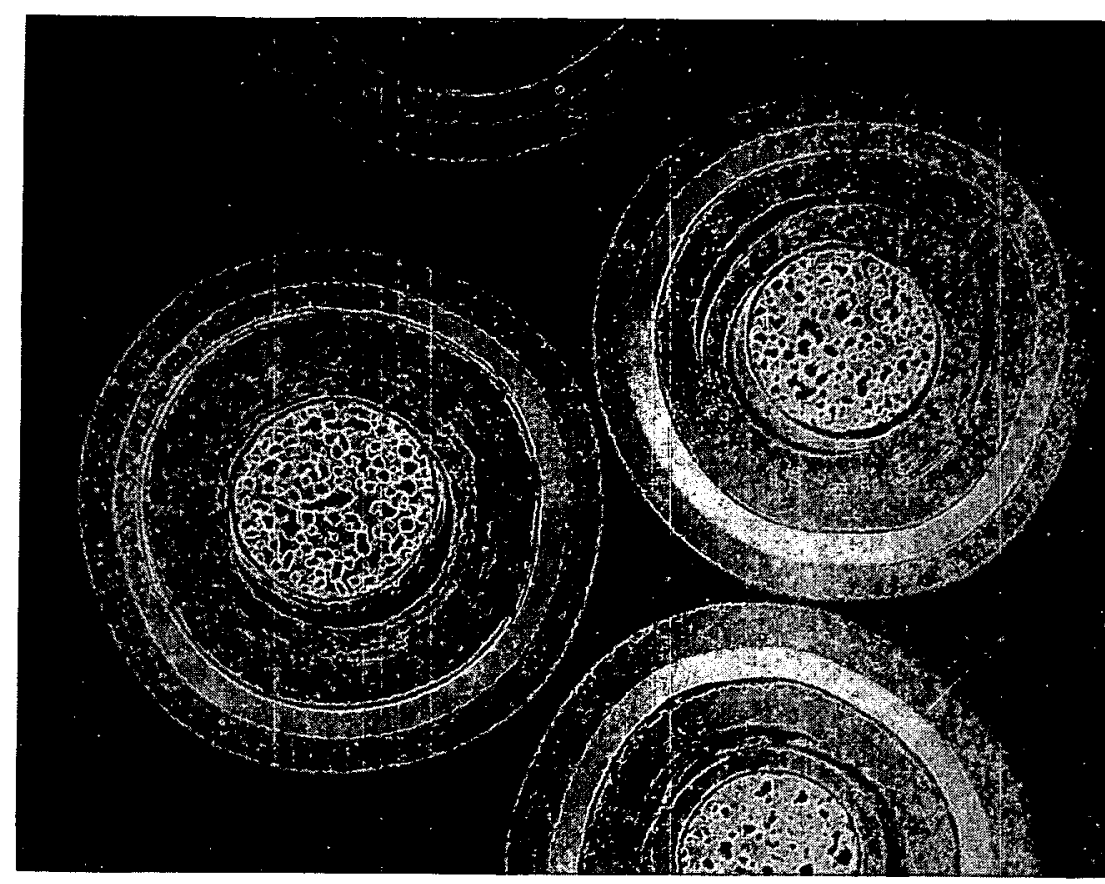

L7311-176

(a)

$150 \mathrm{X}$

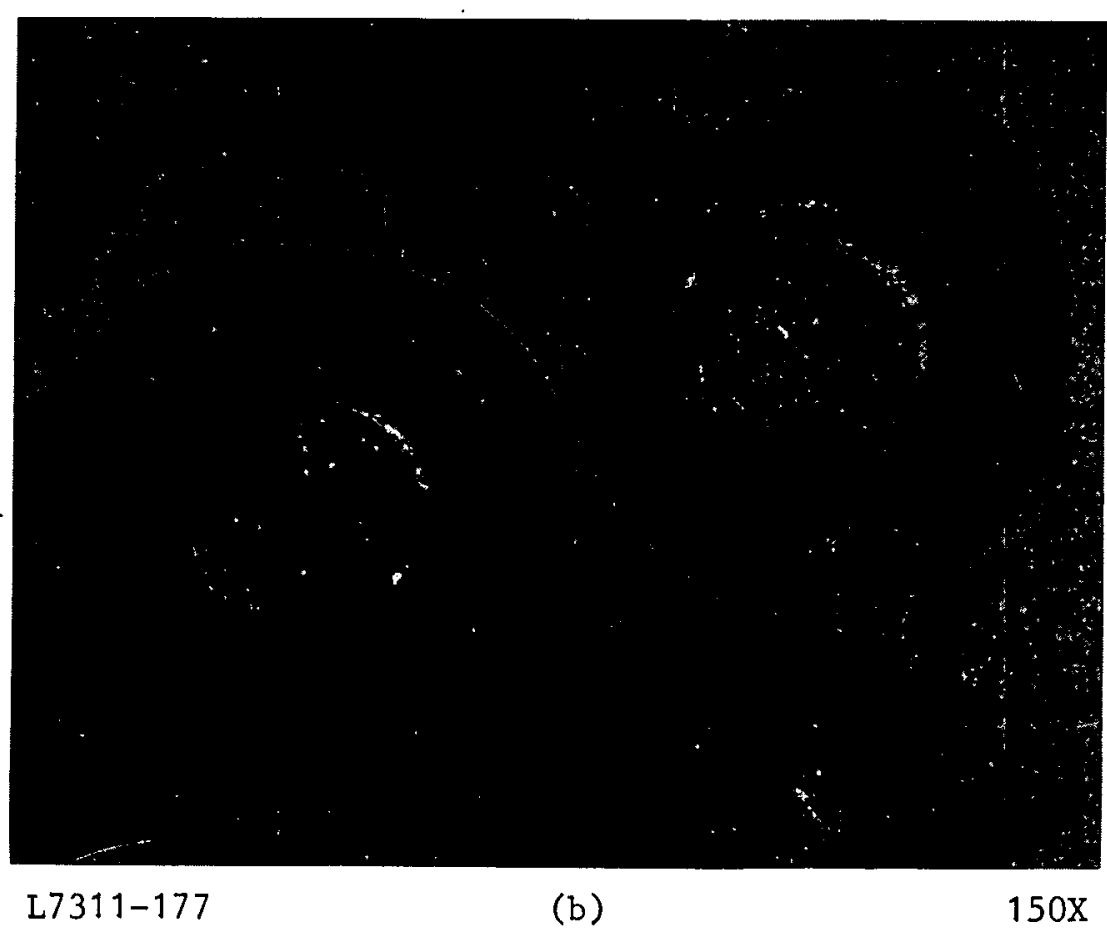

Fig. 54. FTE-3 thermal stability spine sample 29-6, metallography. Representative photomicrographs of TRISO-coated $\mathrm{UO}_{2}$ particles (Batch No. 4413-67) irradiated in FTE-3 (crucible 29-6) to 0.34 $x 10^{21} \mathrm{n} / \mathrm{cm}^{2}$ at $829^{\circ} \mathrm{C}$ : (a) bright field and (b) polarized light. The fuel kernels exhibited $\sim 10 \mu \mathrm{m}$ unidirectional migration. 


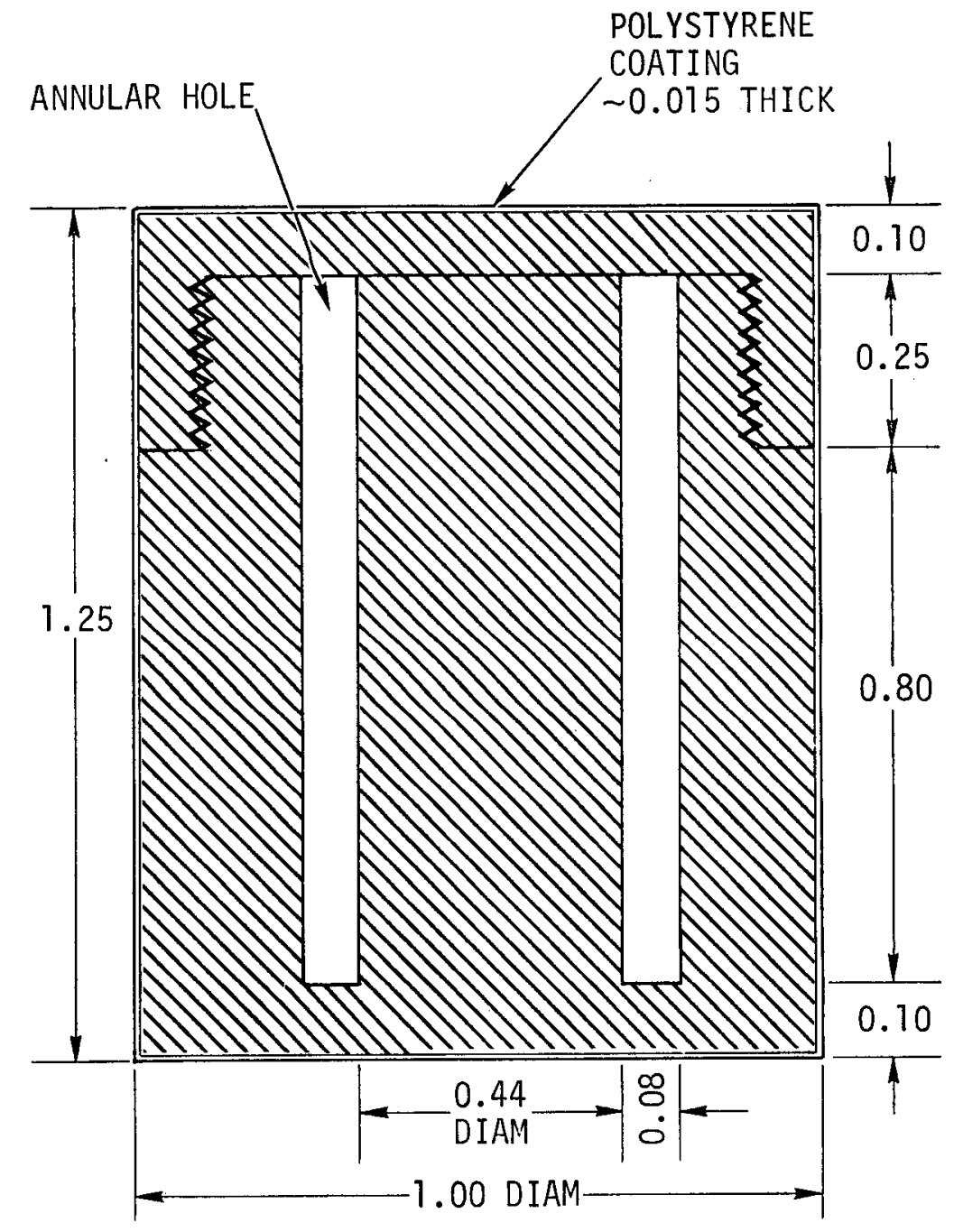

ALL DIMENSIONS IN INCHES

F1g. 55. Design of diffusion spine samples 


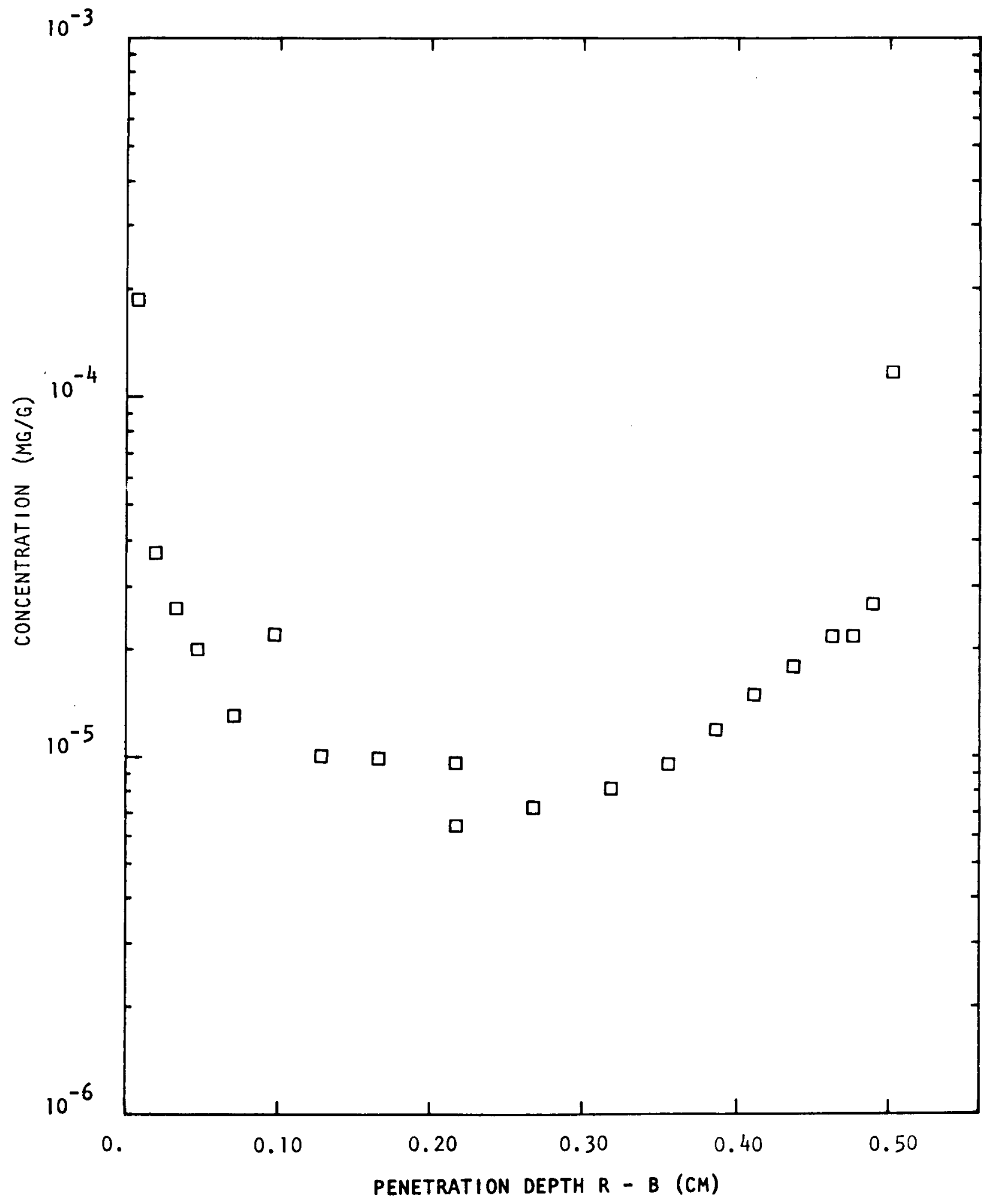

Fig. 56a. FTE-3-3 crucible wall CS-134 


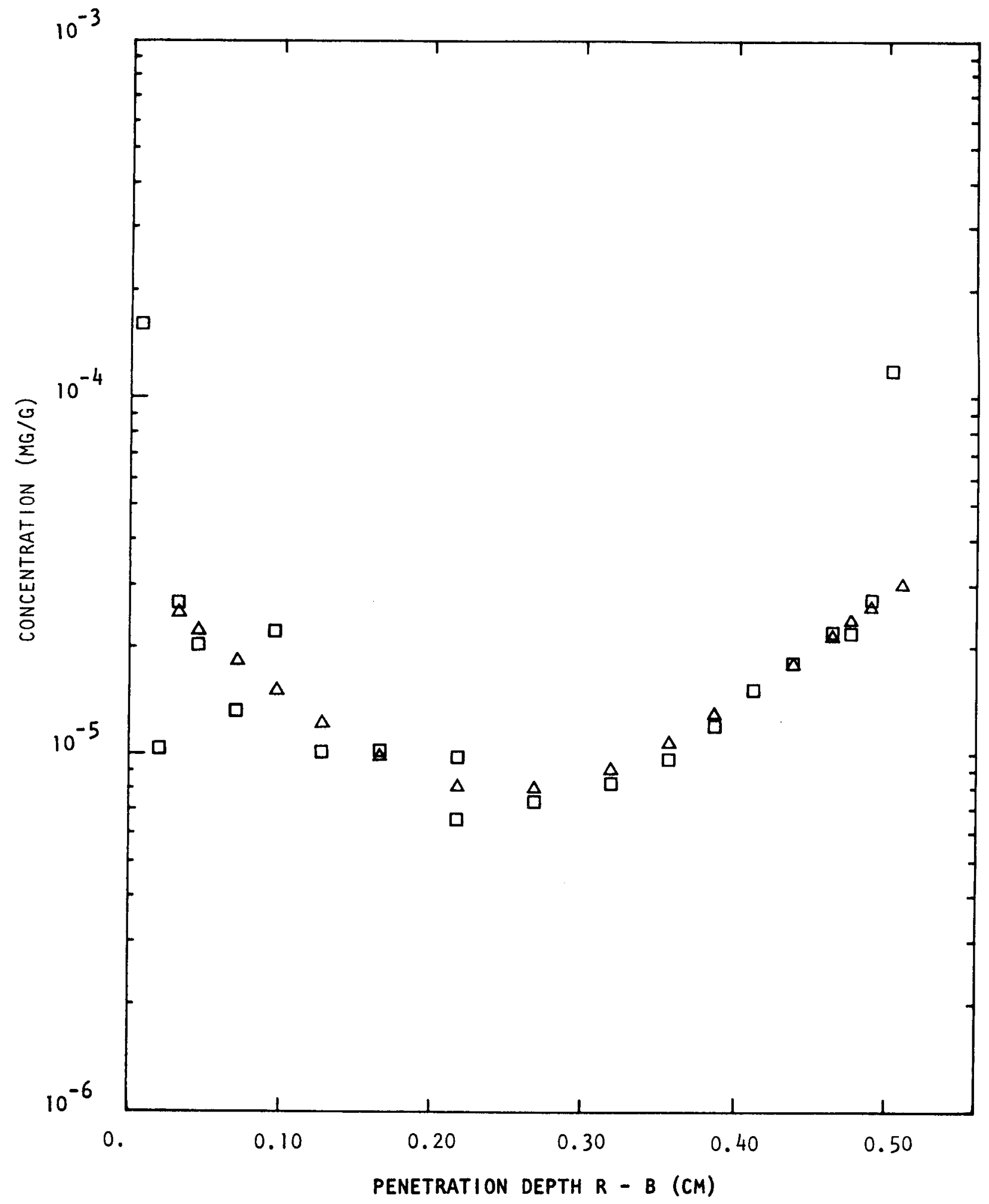

Fig. 56b. FTE-3-3 crucible wall Cs -134 


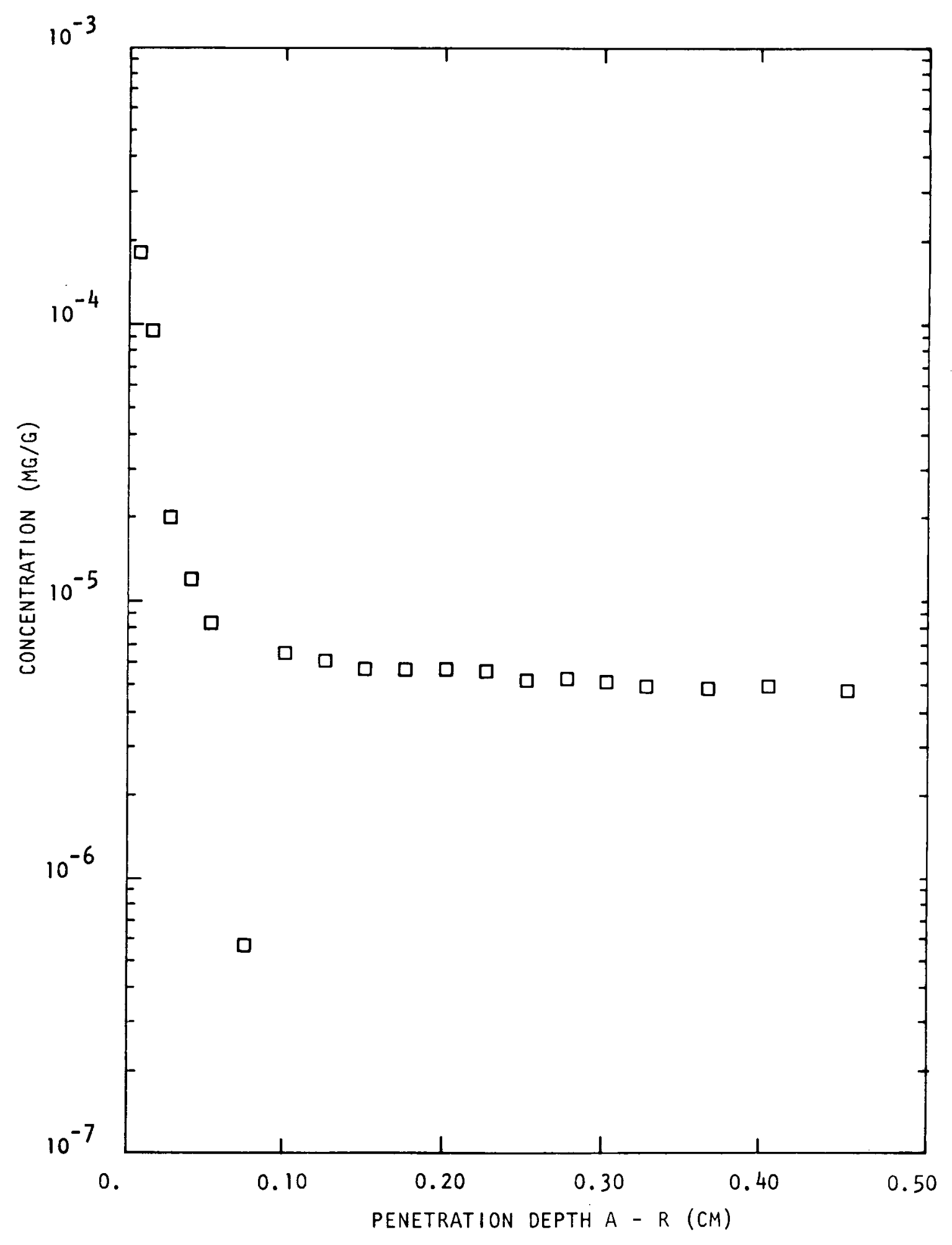

Fig. 57a. FTE-3-3 center post Cs-134 


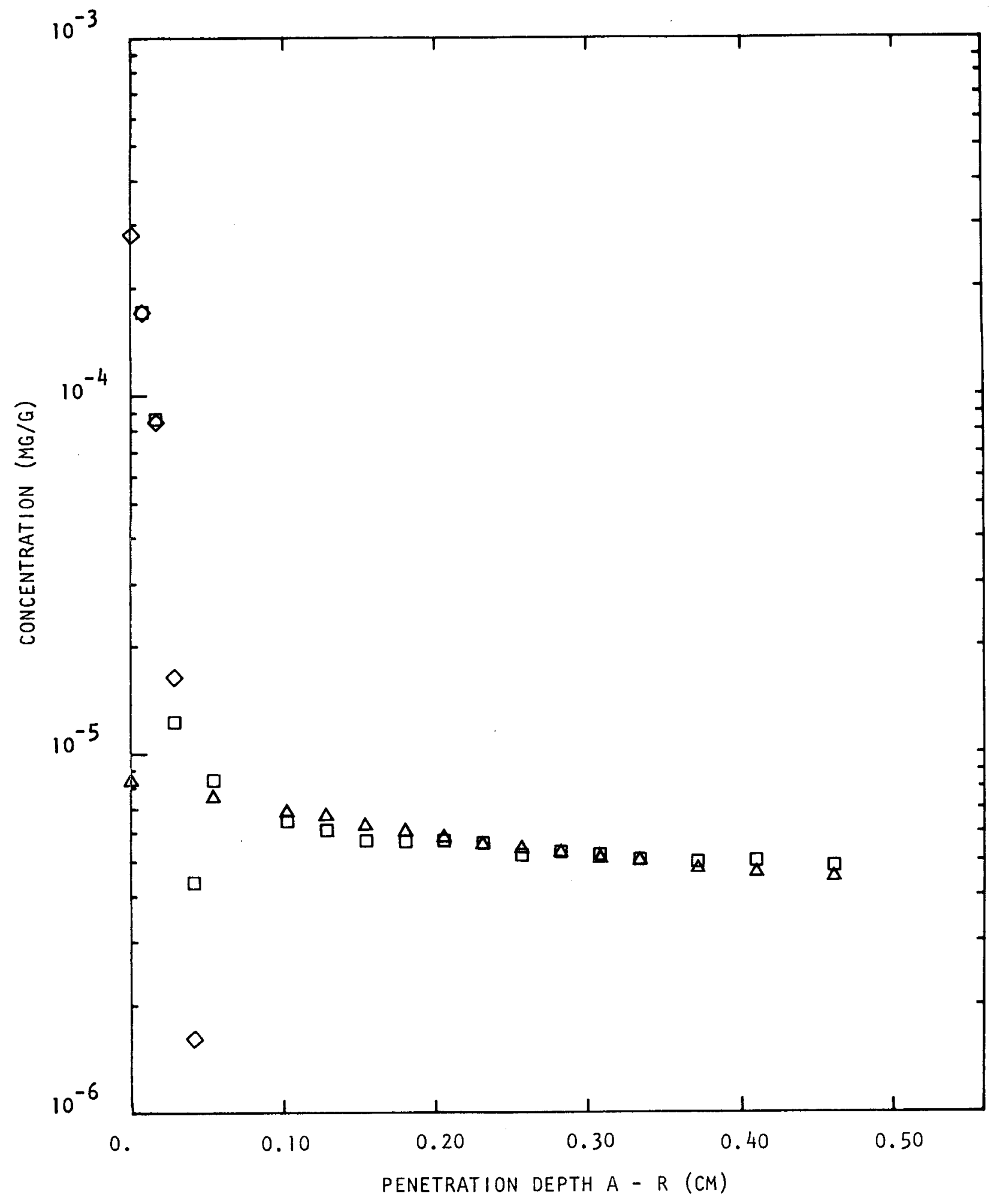

Fig. 57b. FTE-3-3 center post Cs -134 


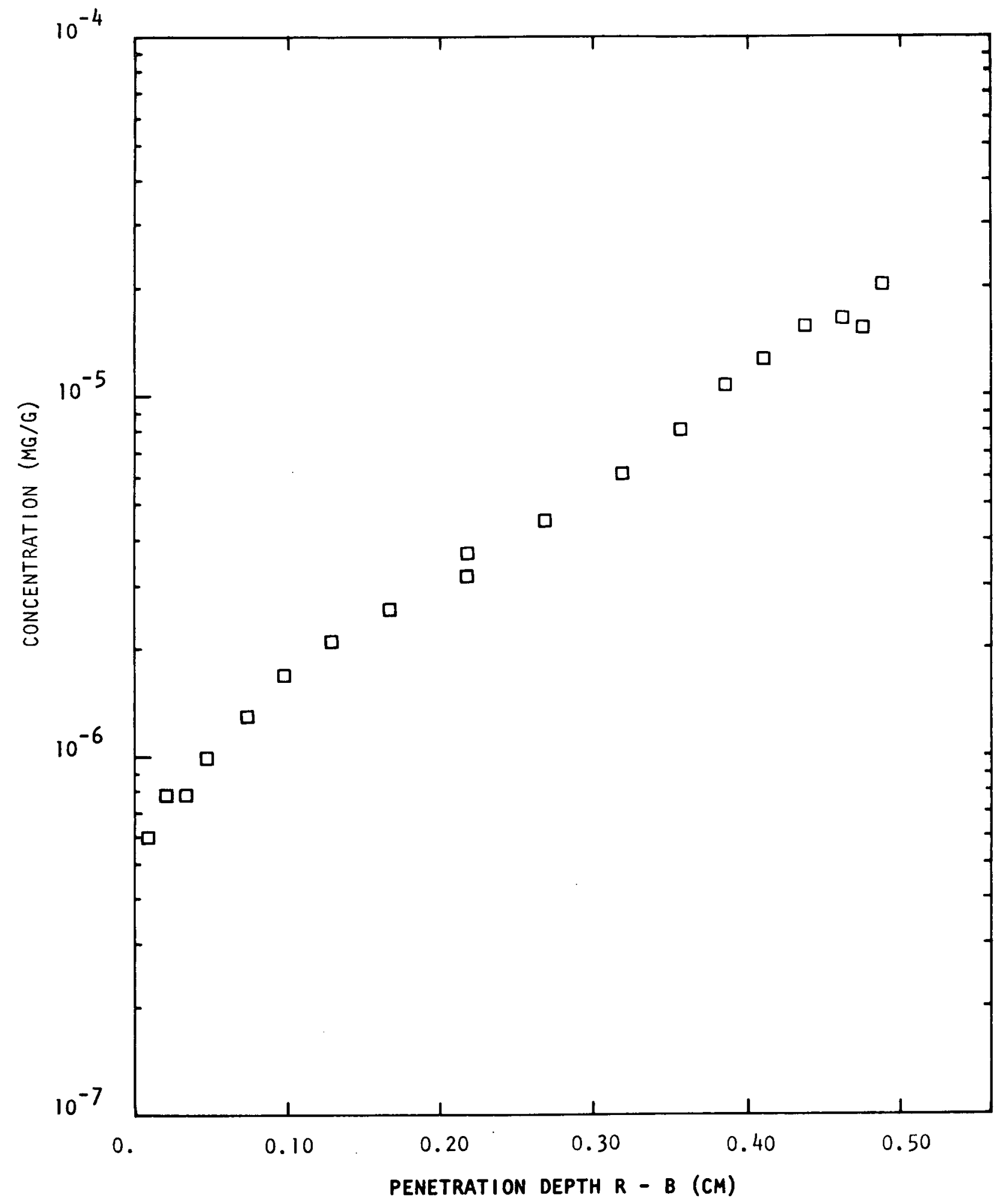

Fig. 58. FTE-3-11 crucible wall Cs-134 


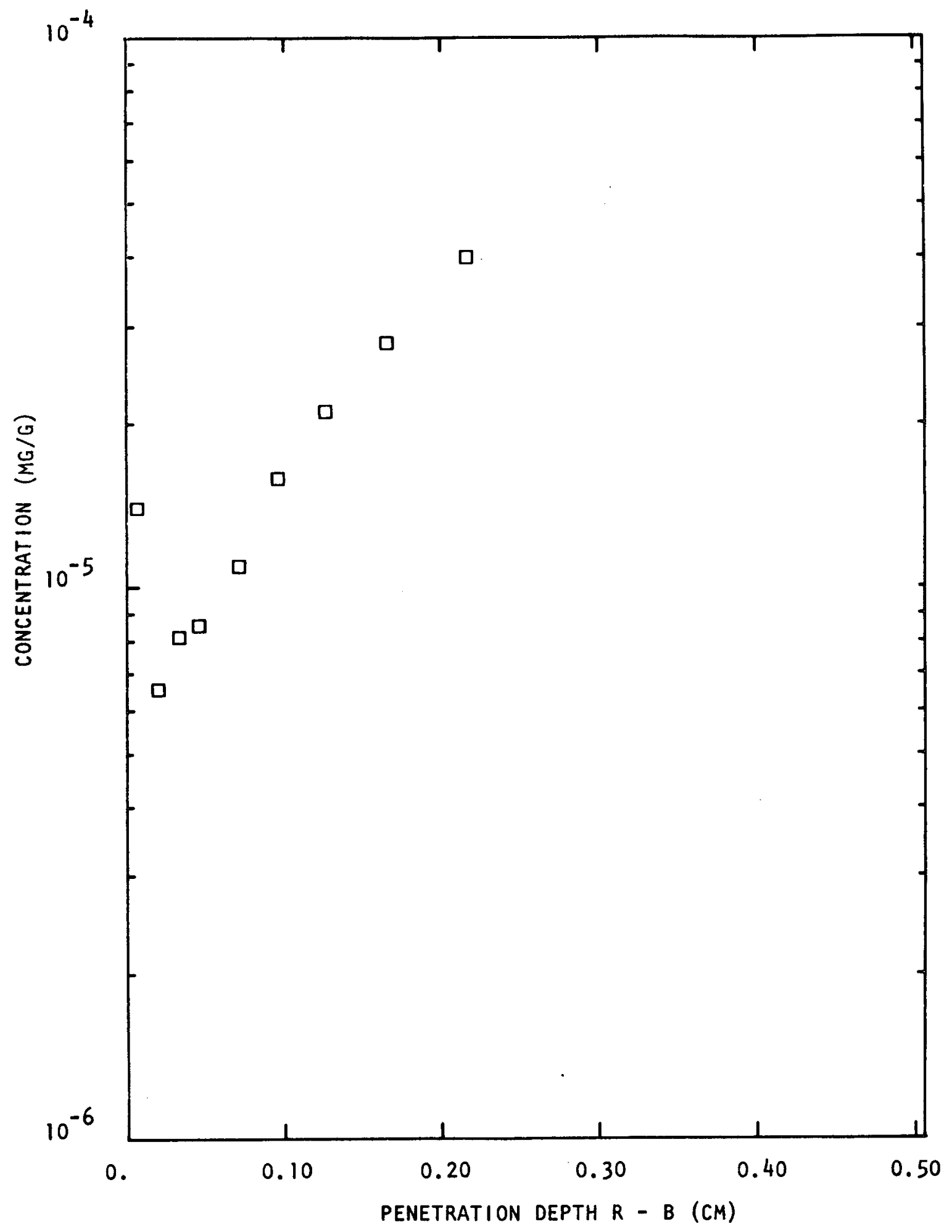

Fig. 59. FTE-3-16 crucible wall Cs-134 


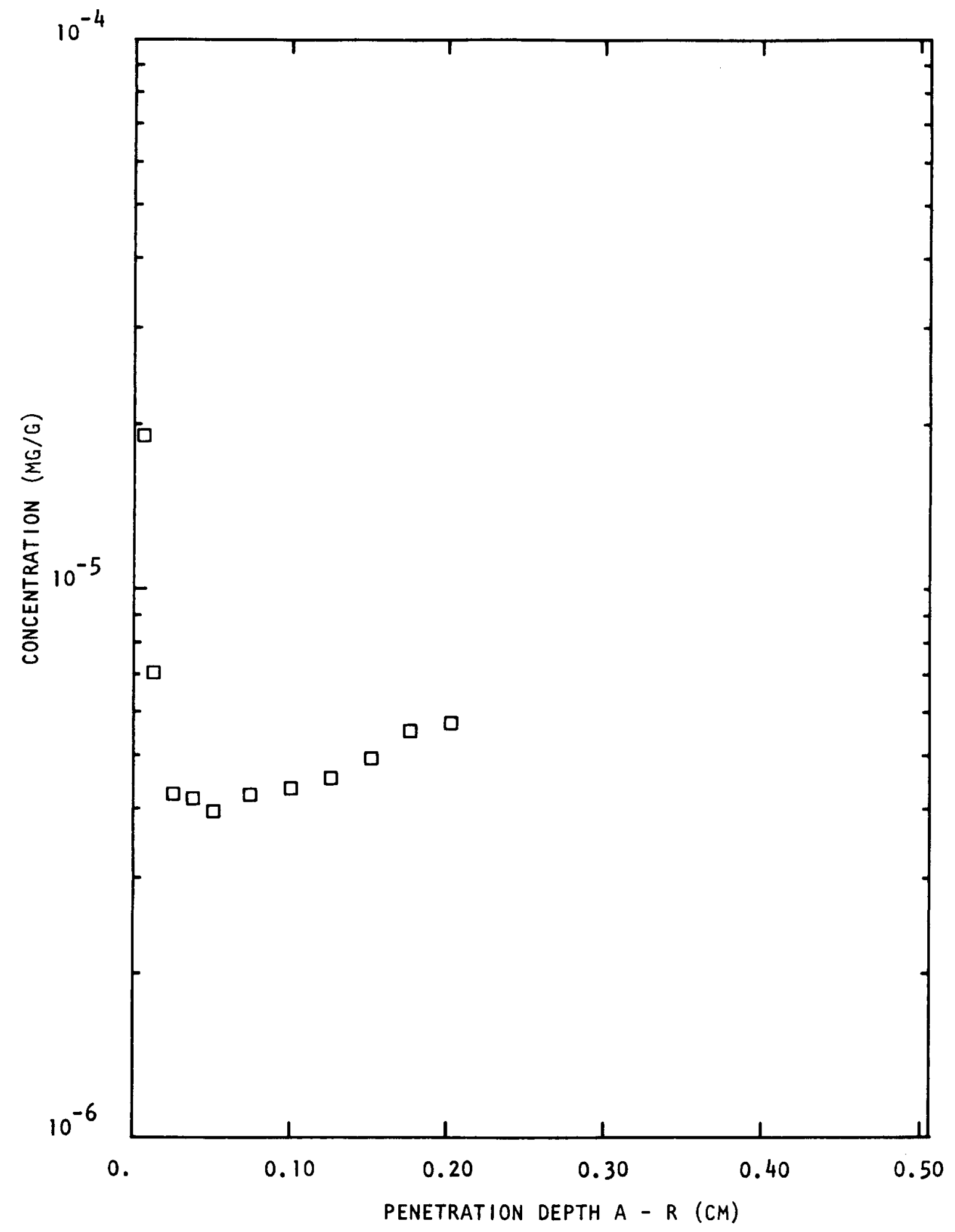

Fig. 60. FTE-3-16 center post Cs -134 


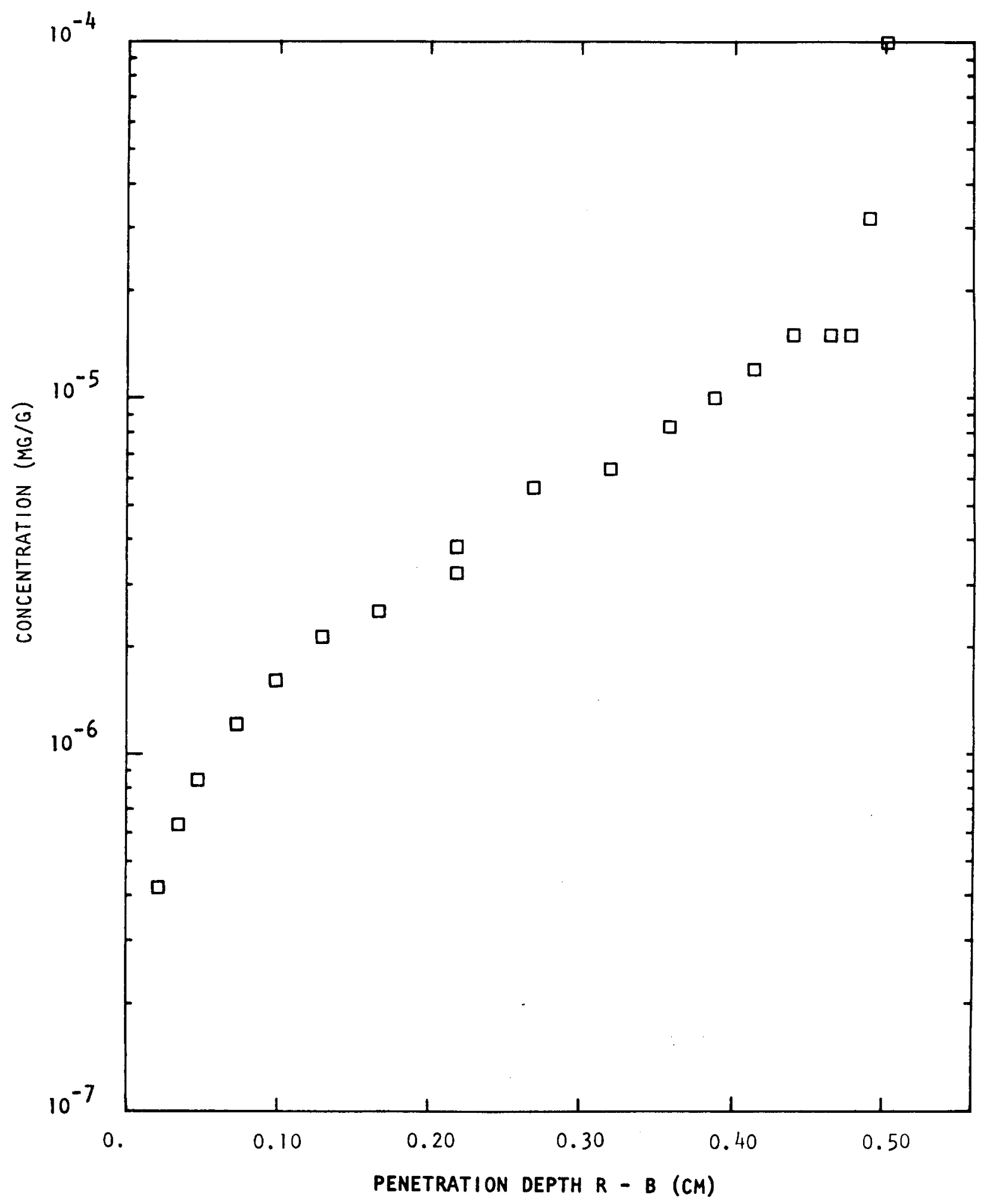

Fig. 61. FTE-3-24 crucible wal1 Cs-134 


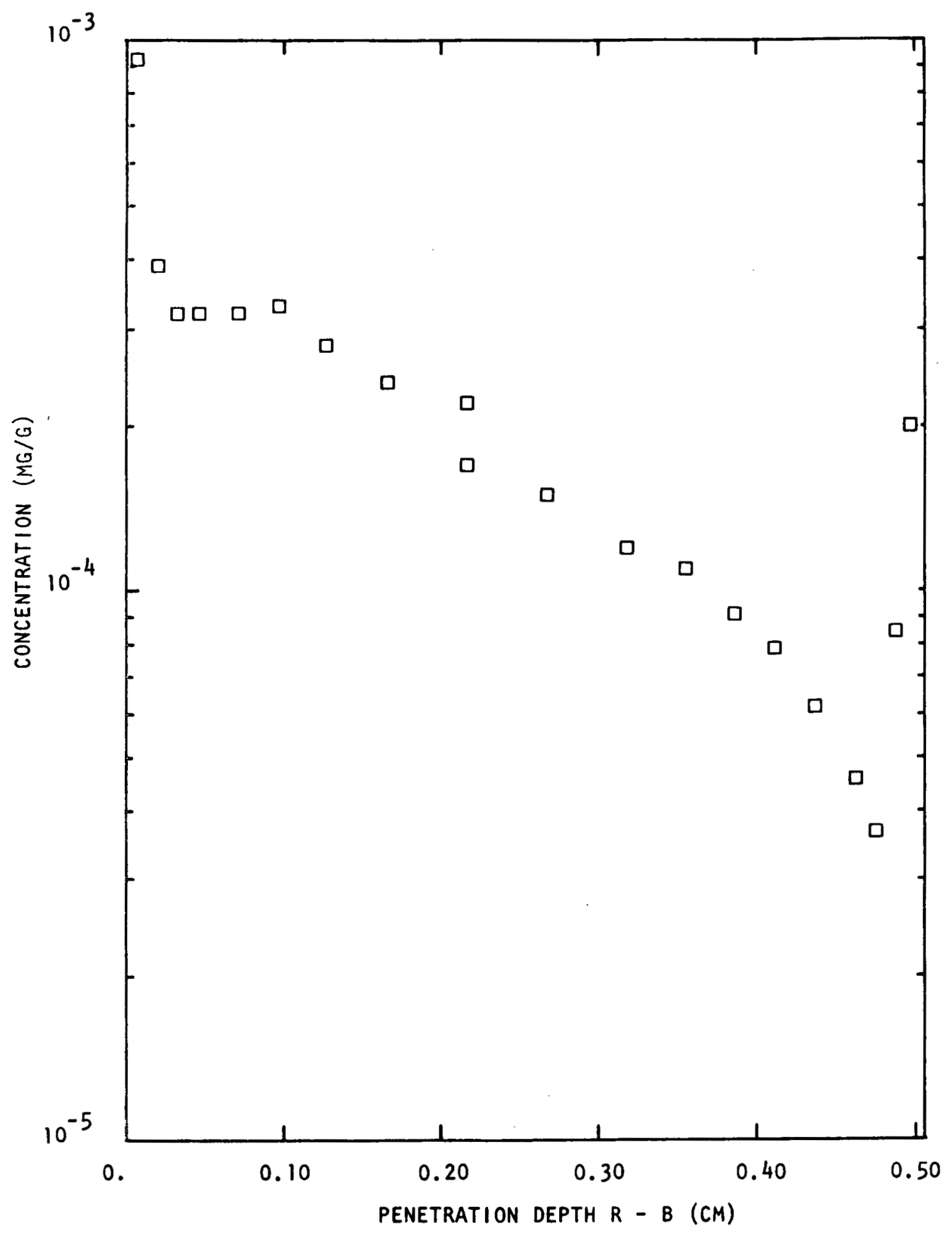

Fig. 62a. FTE-3-42 crucible wall Cs-134 


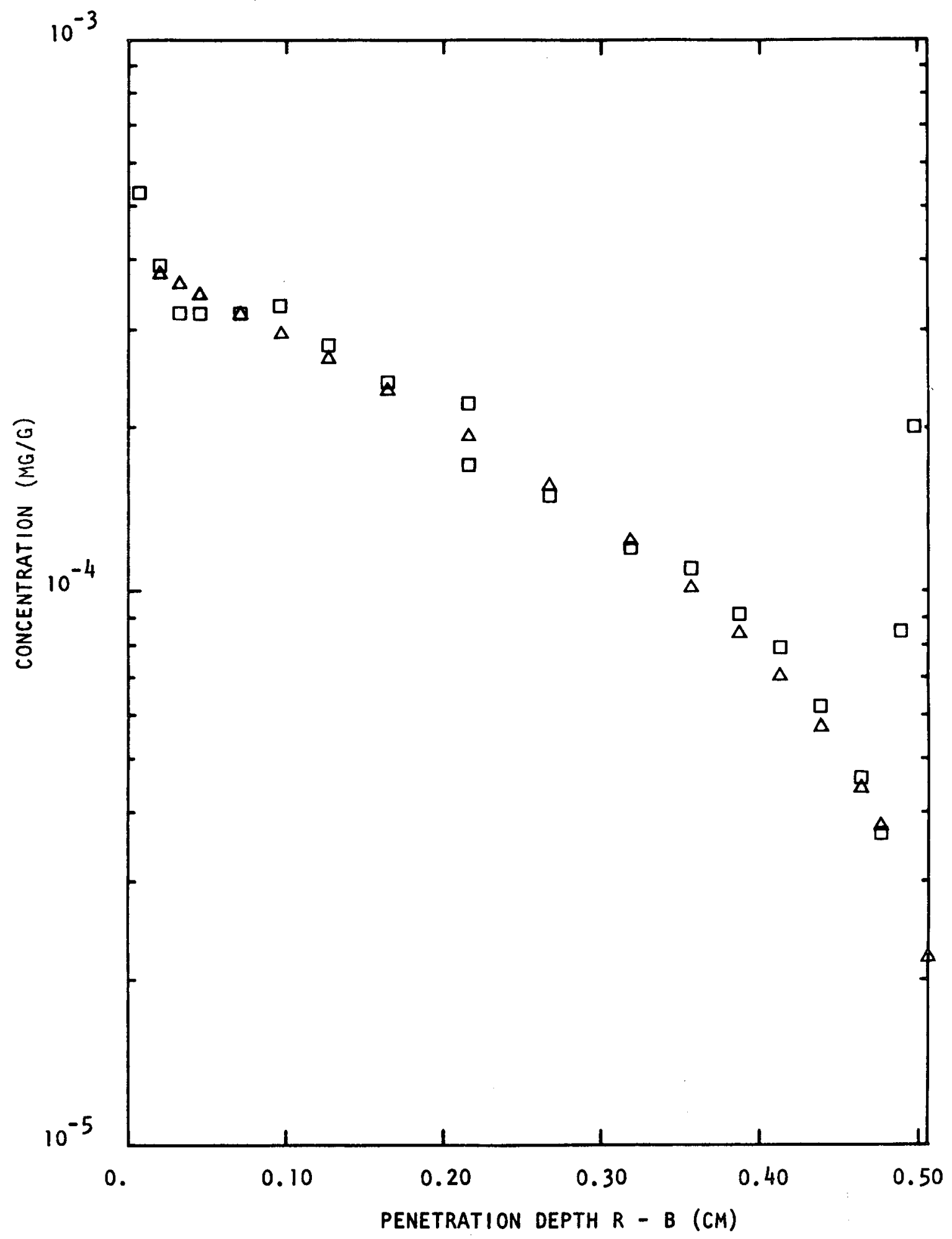

Fig. 62b. FTE-3-42 crucible wall Cs-134 


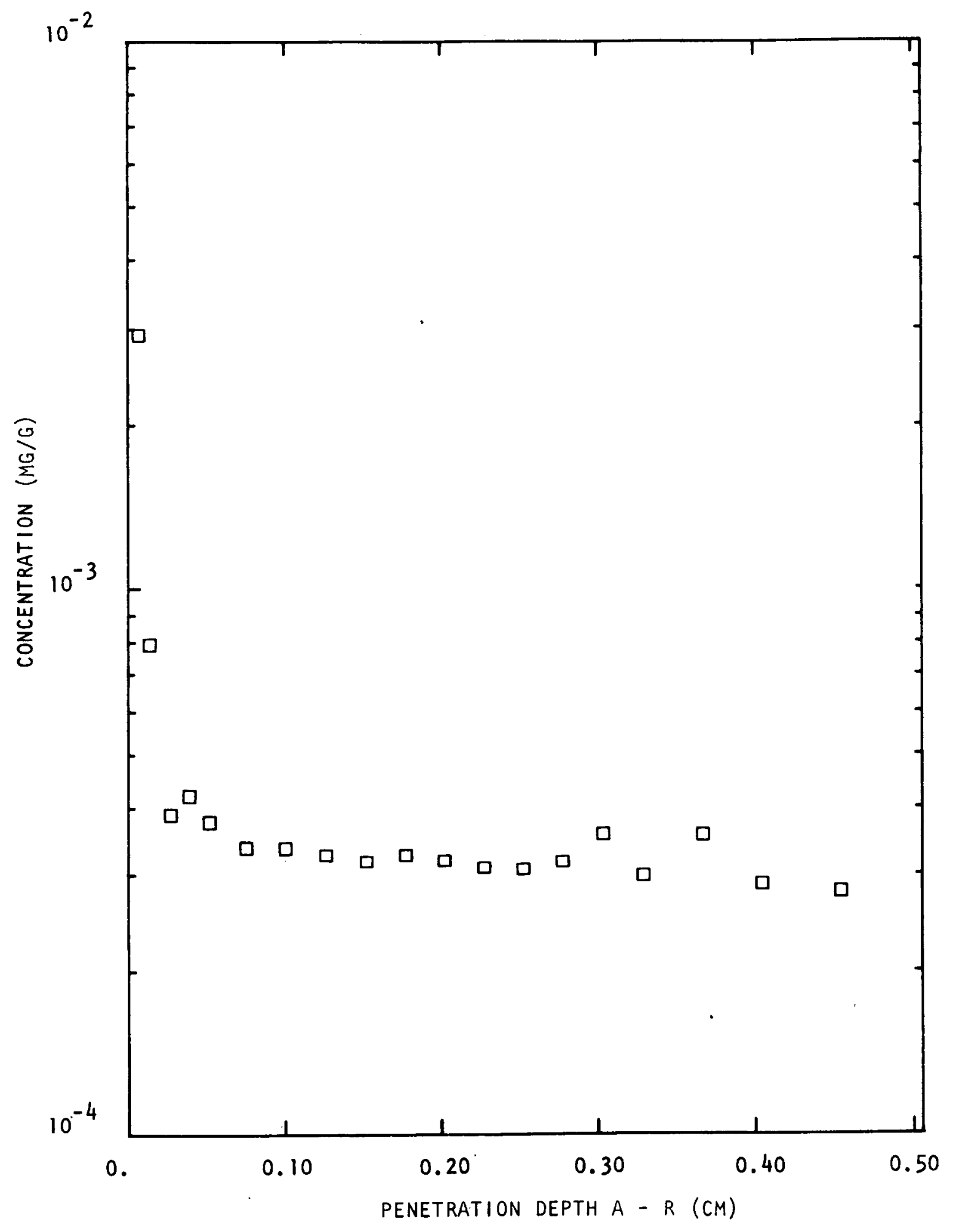

Fig. 63a. FTE-3-42 center post Cs -134 


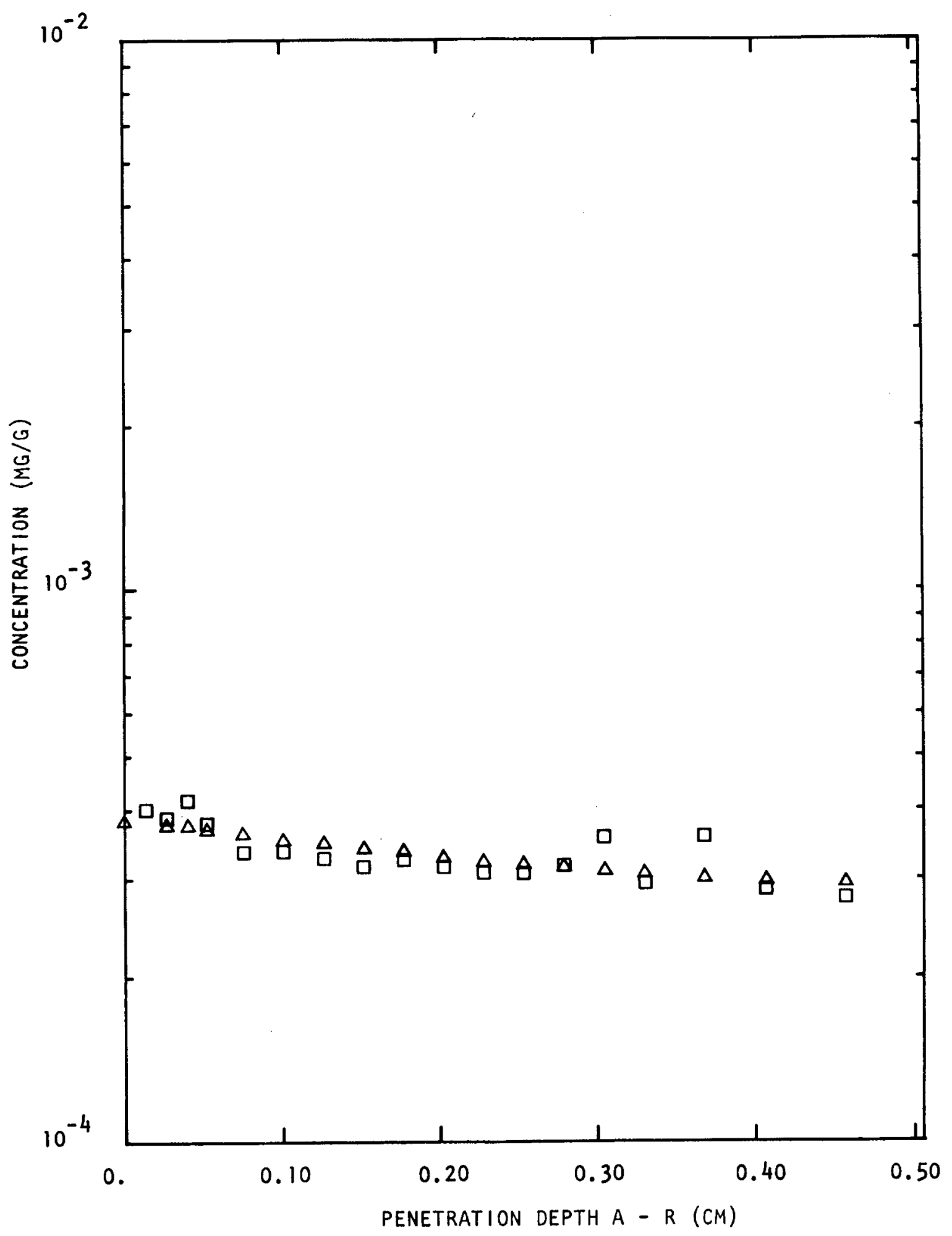

Fig. 63b. FTE-3-42 center post Cs -134 


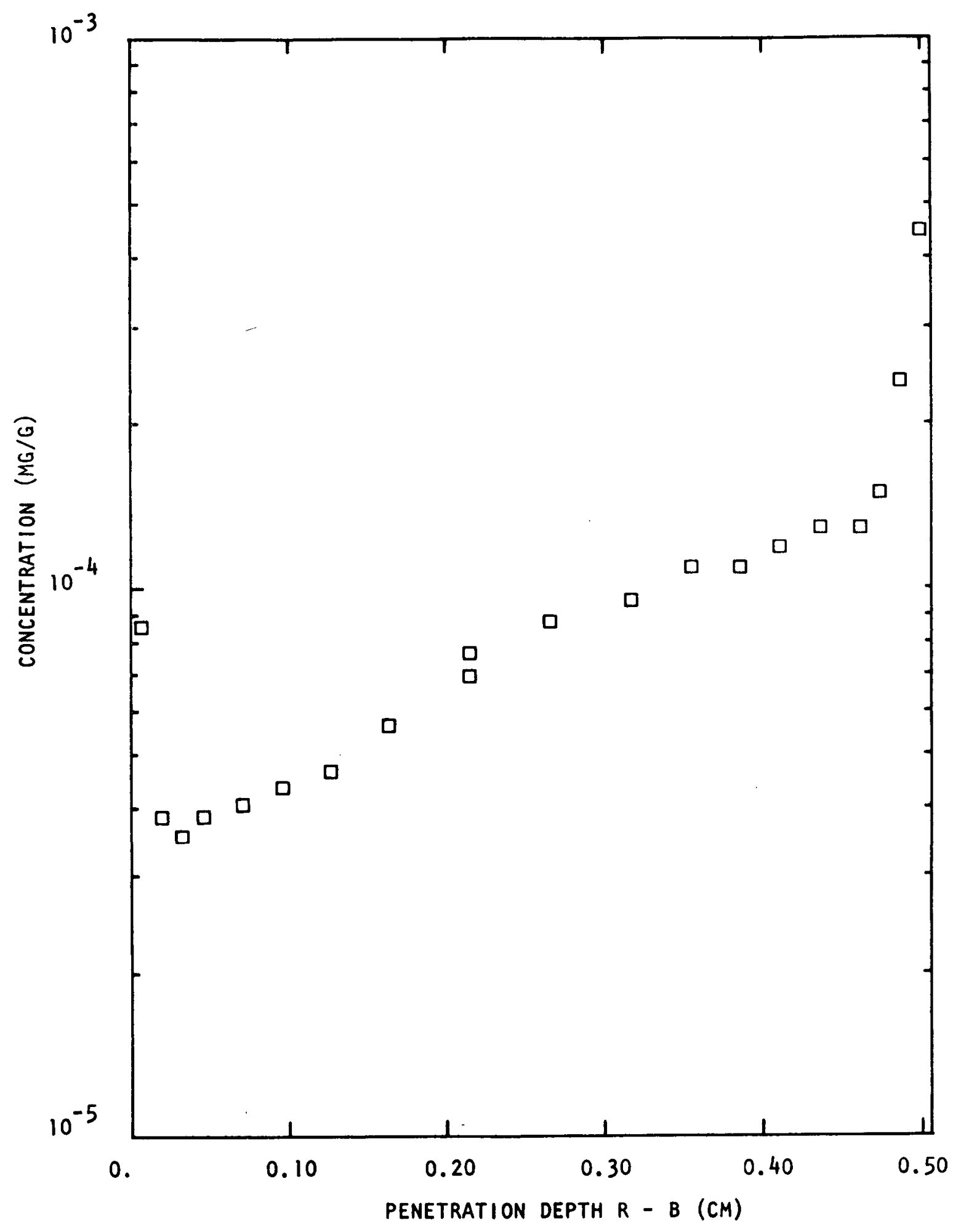

Fig. 64a. FTE-3-45 crucible wall Cs-134 


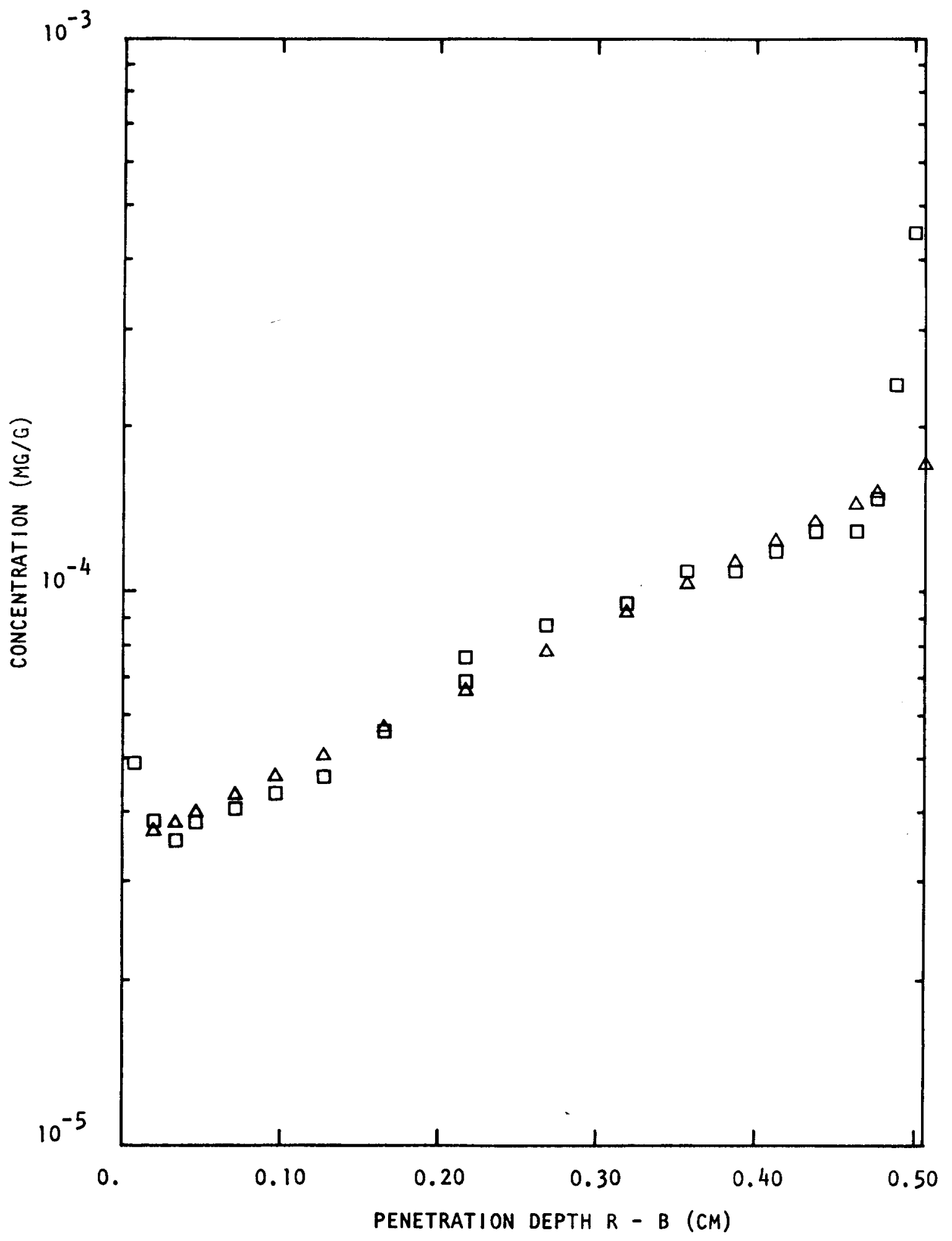

Fig. 64b. FTE-3-45 crucible wall Cs-134 


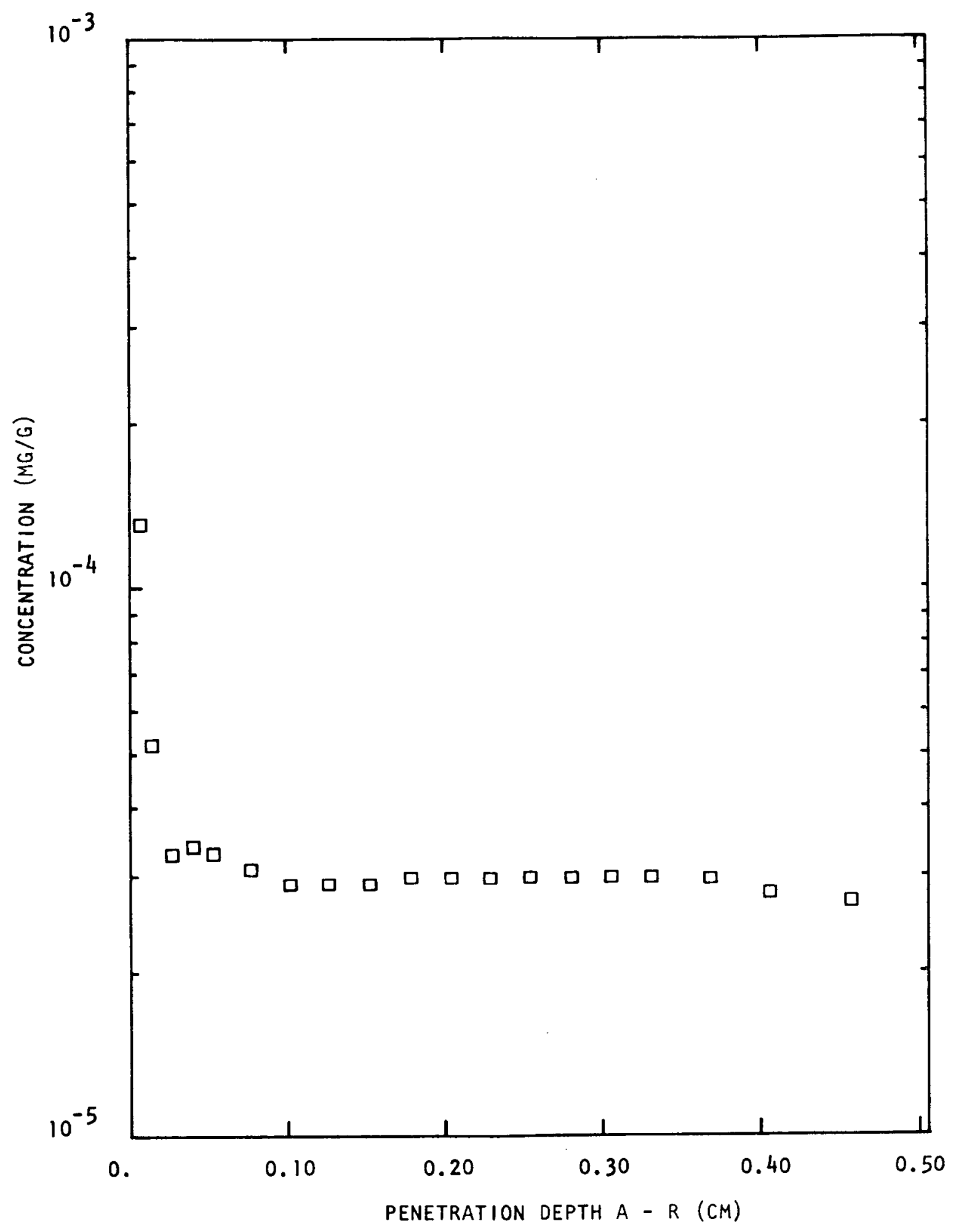

Fig. 65. FTE-3-45 center post Cs -134 


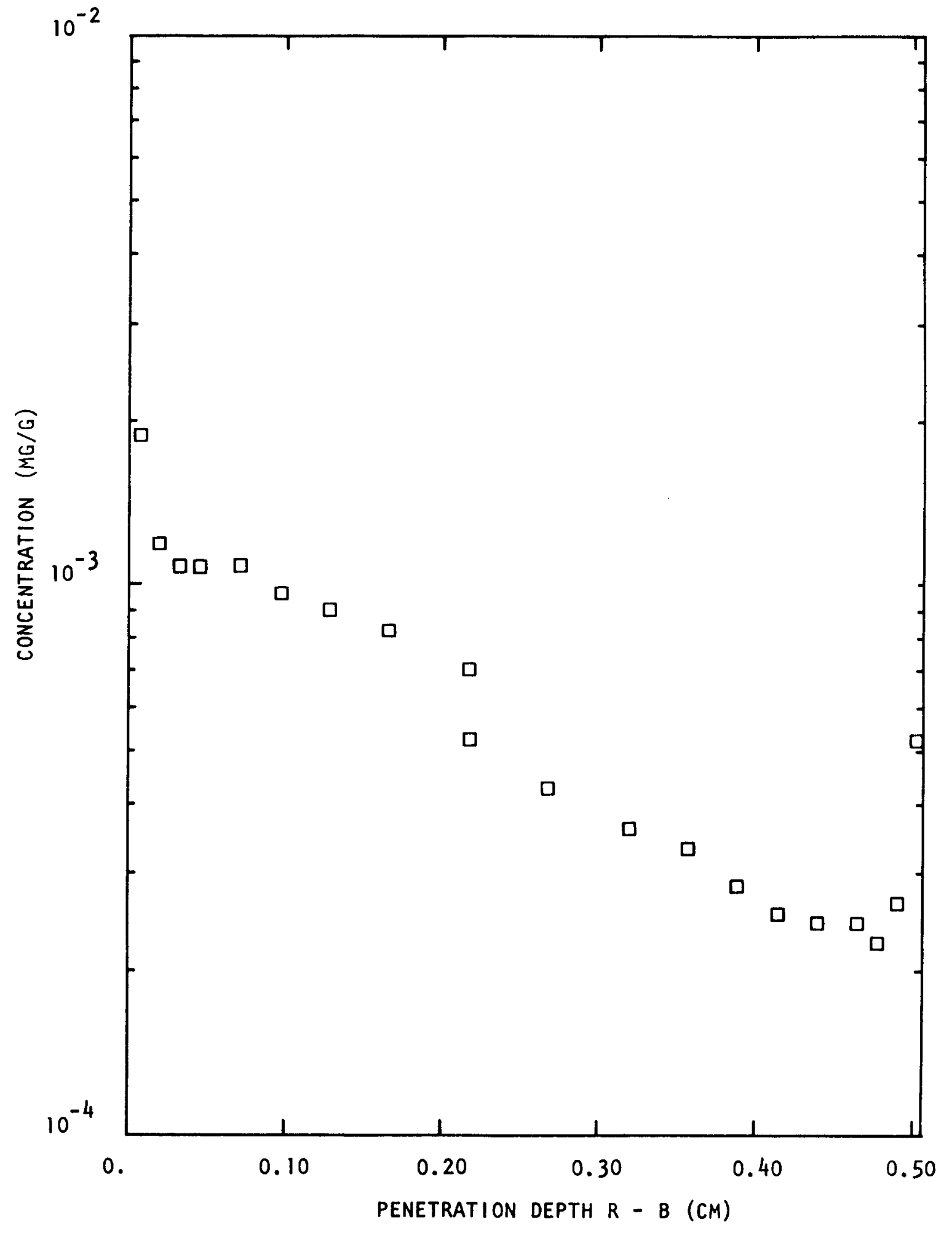

Fig. 66a. FTE-3-55 crucible wall Cs-134 


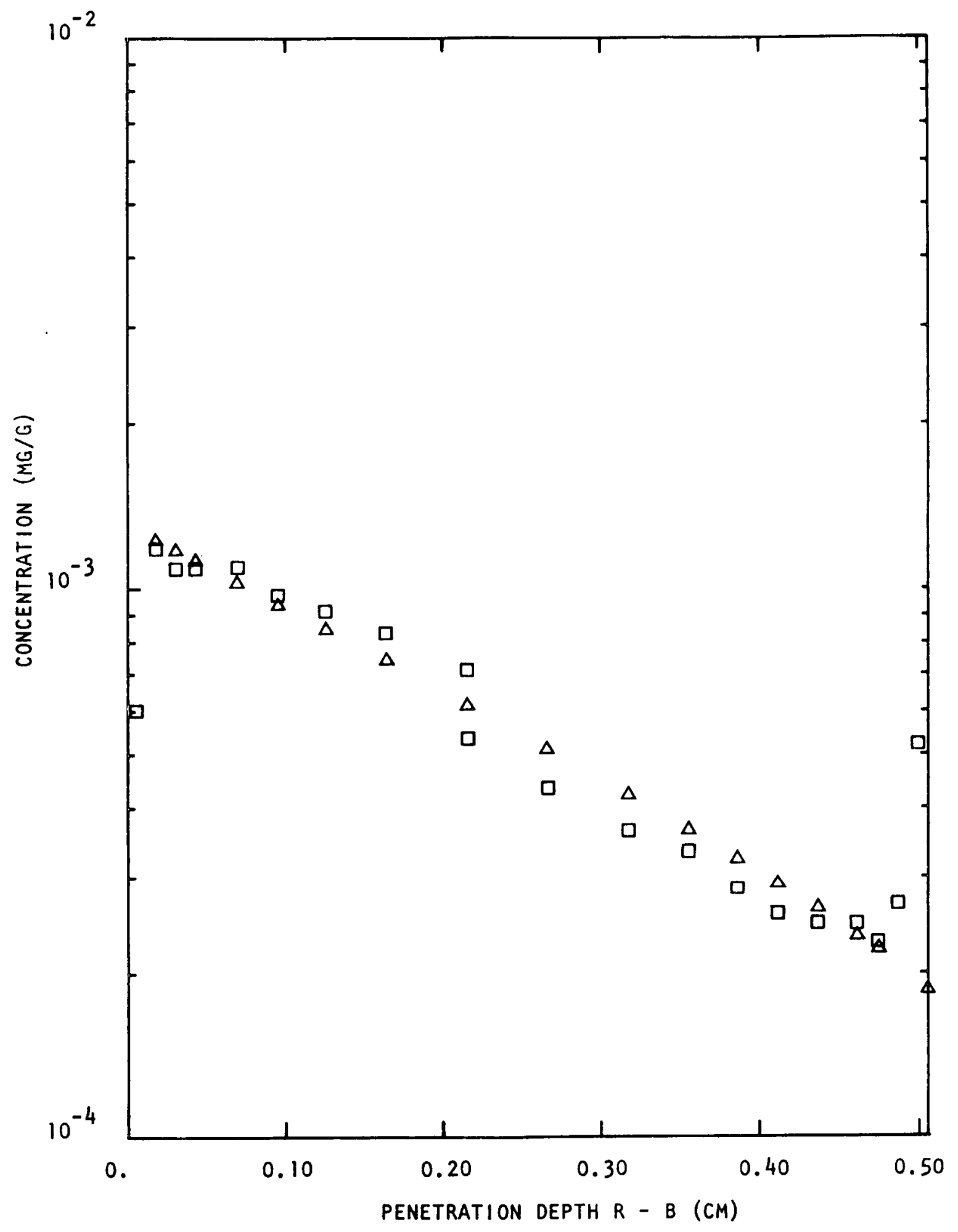

Fig. 66b. FTE-3-55 crucible wall Cs-134 


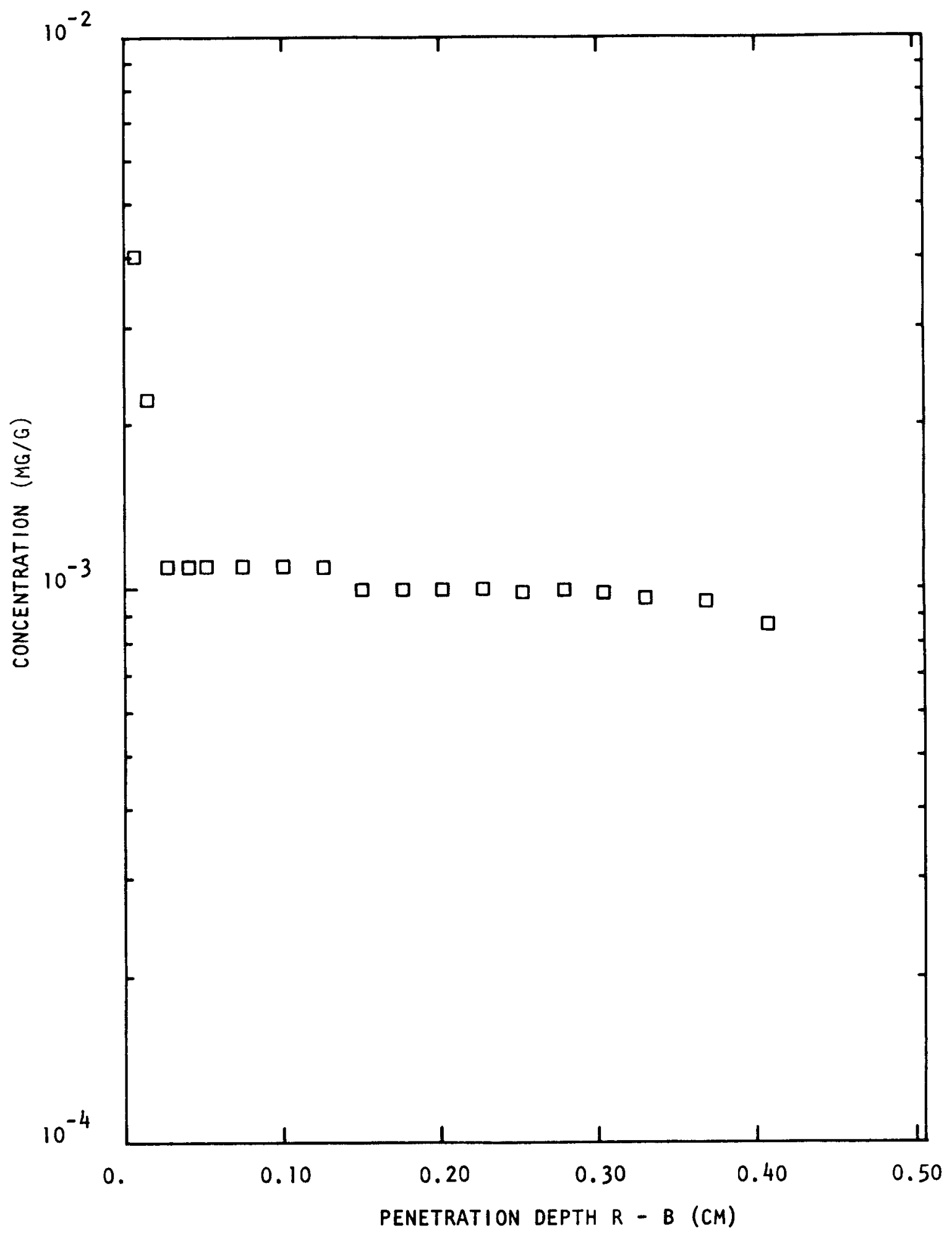

Fig. 67a. FTE-3-55 center post Cs -134 


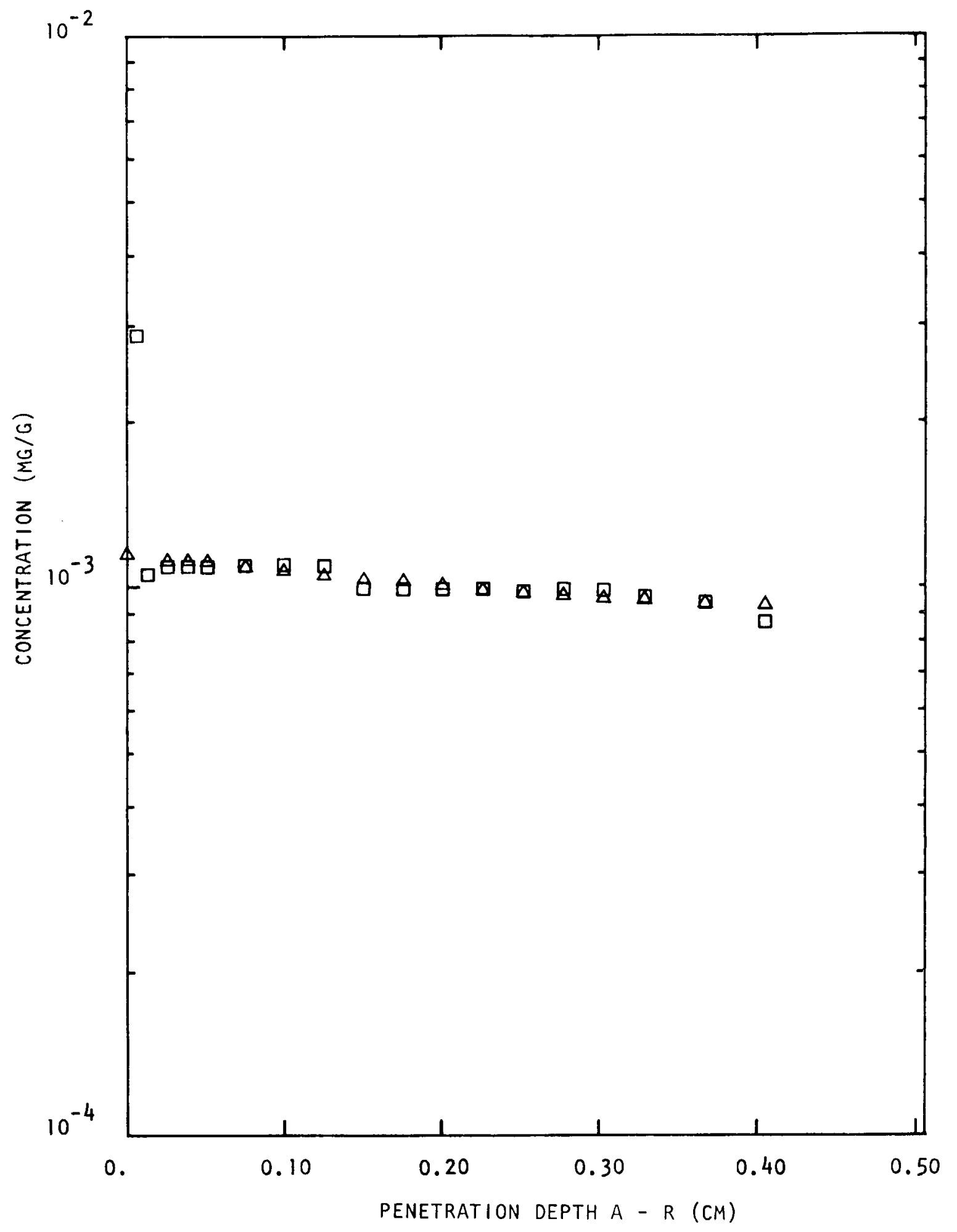

Fig. $67 \mathrm{~b}$. FTE-3-55 center post Cs -134 


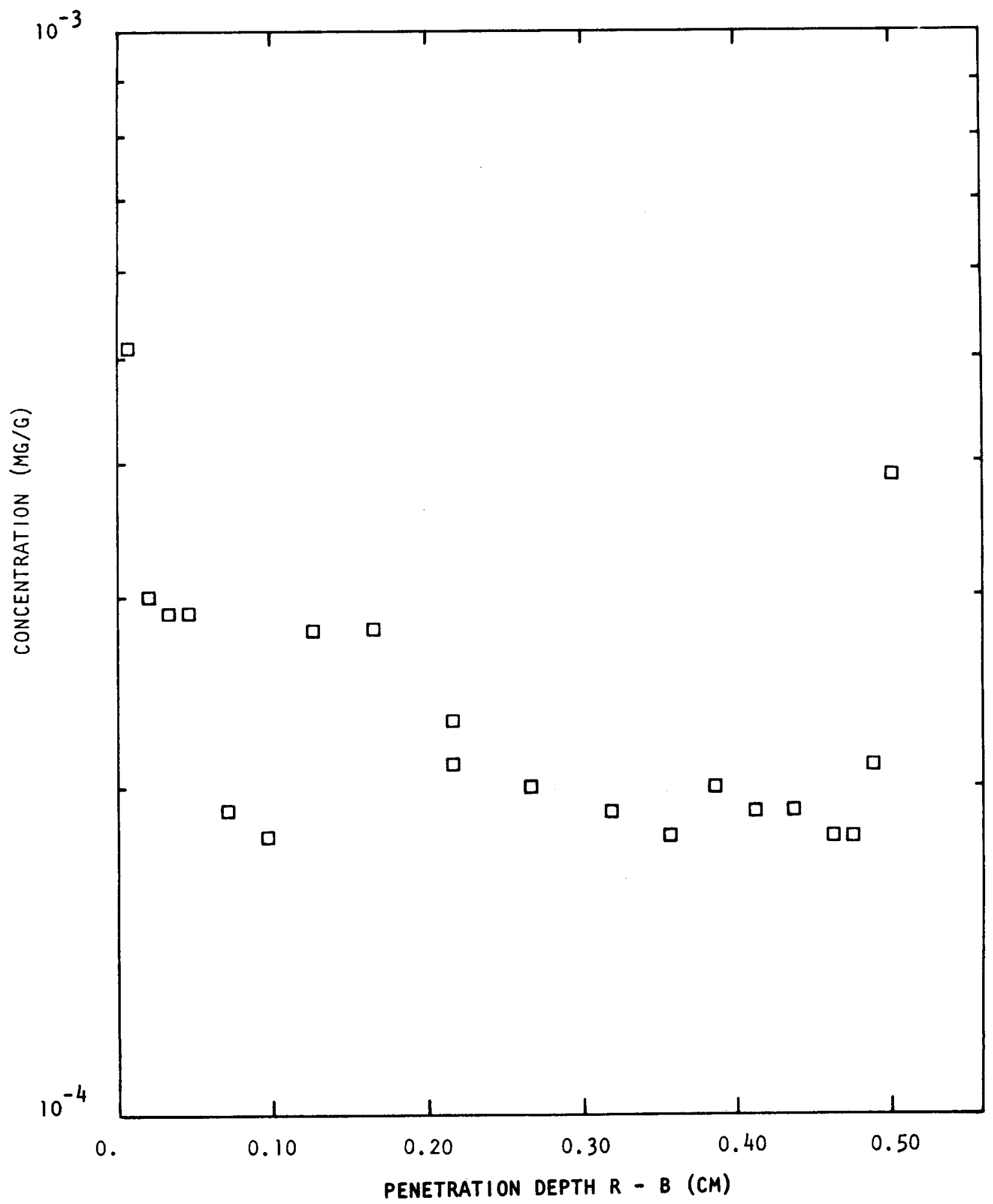

Fig. 68. FTE-3-63 crucible wal1 Cs-134 


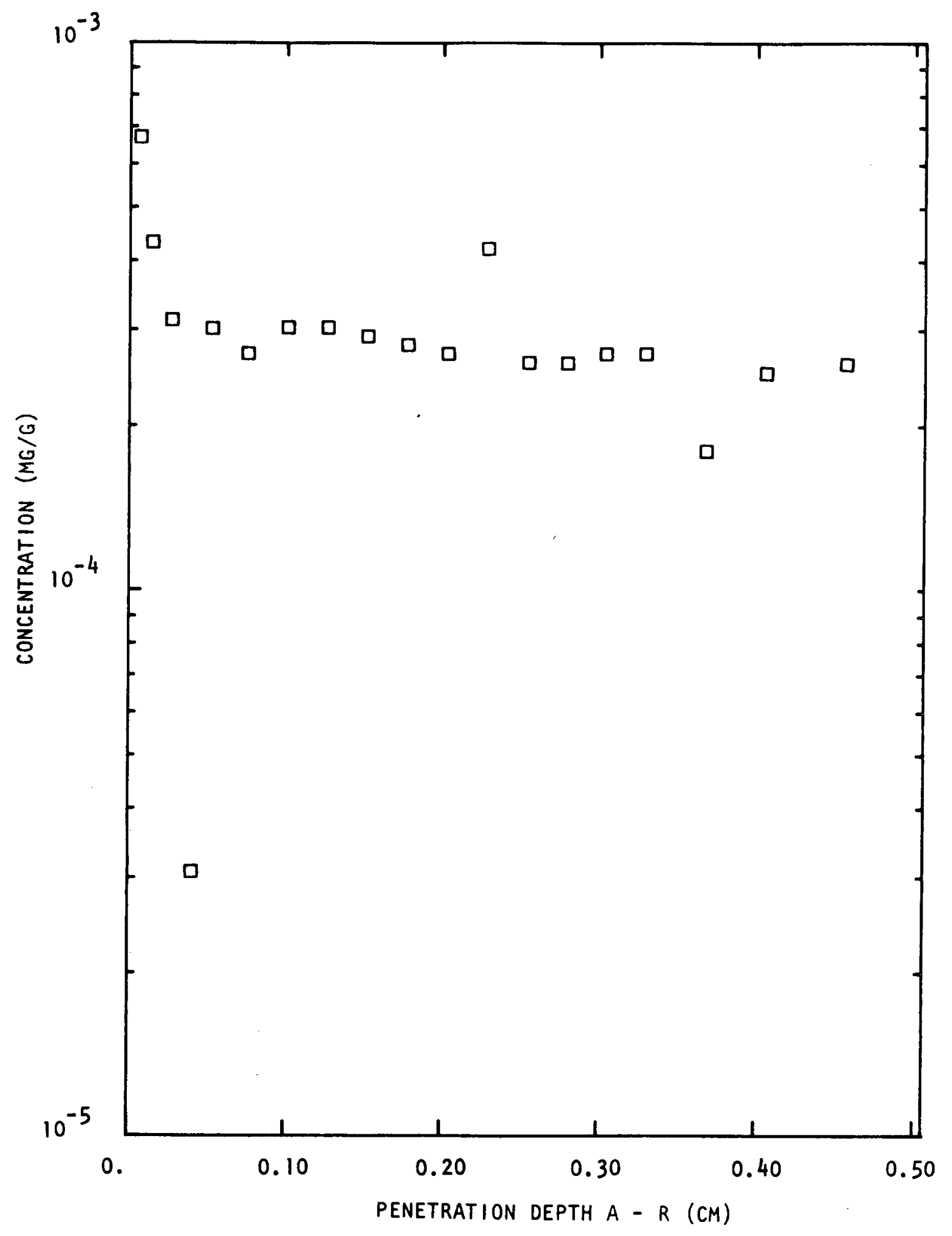

Fig. 69. FTE-3-63 center post Cs-134 


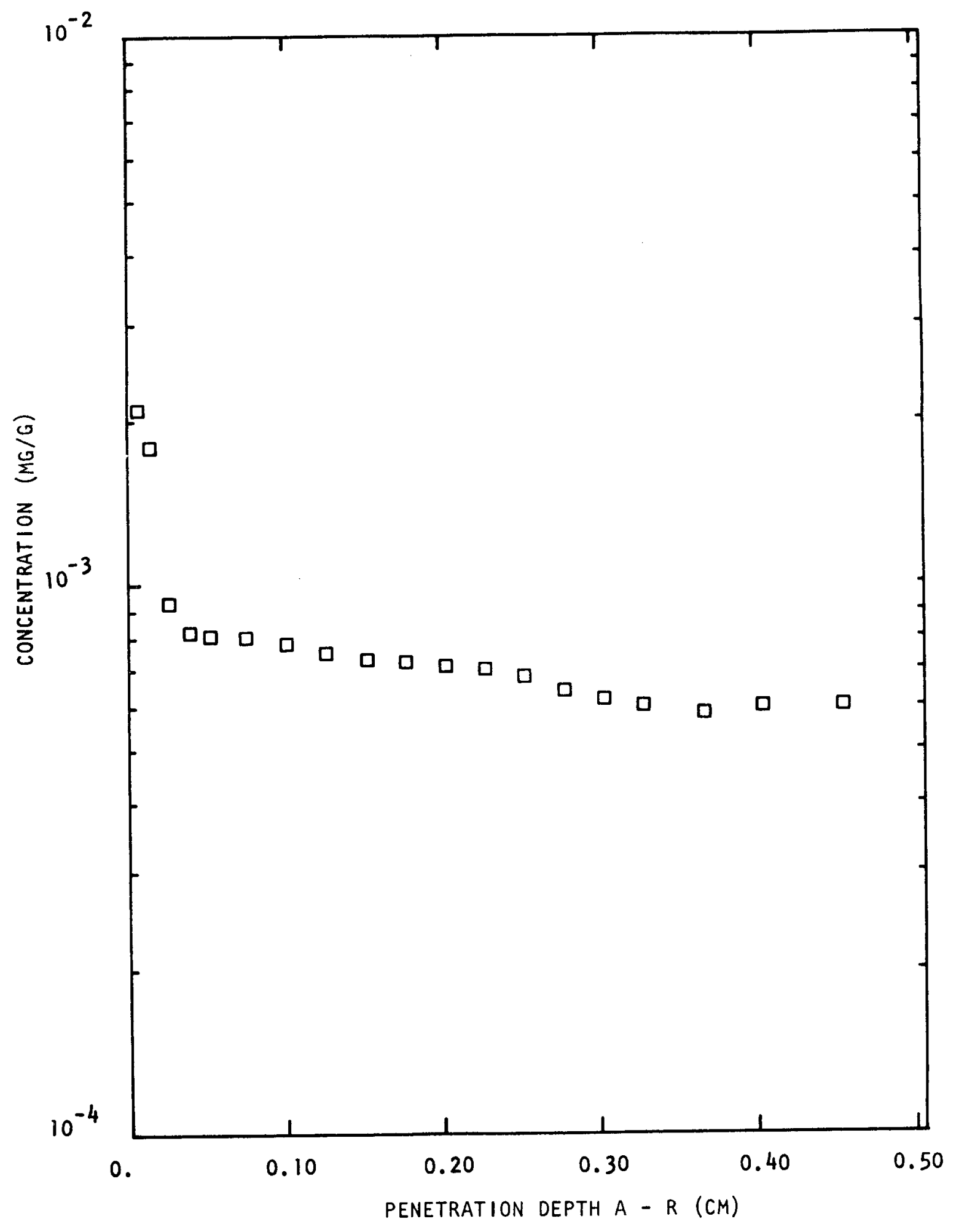

Fig. 70a. FTE-3-66 center post Cs -134 


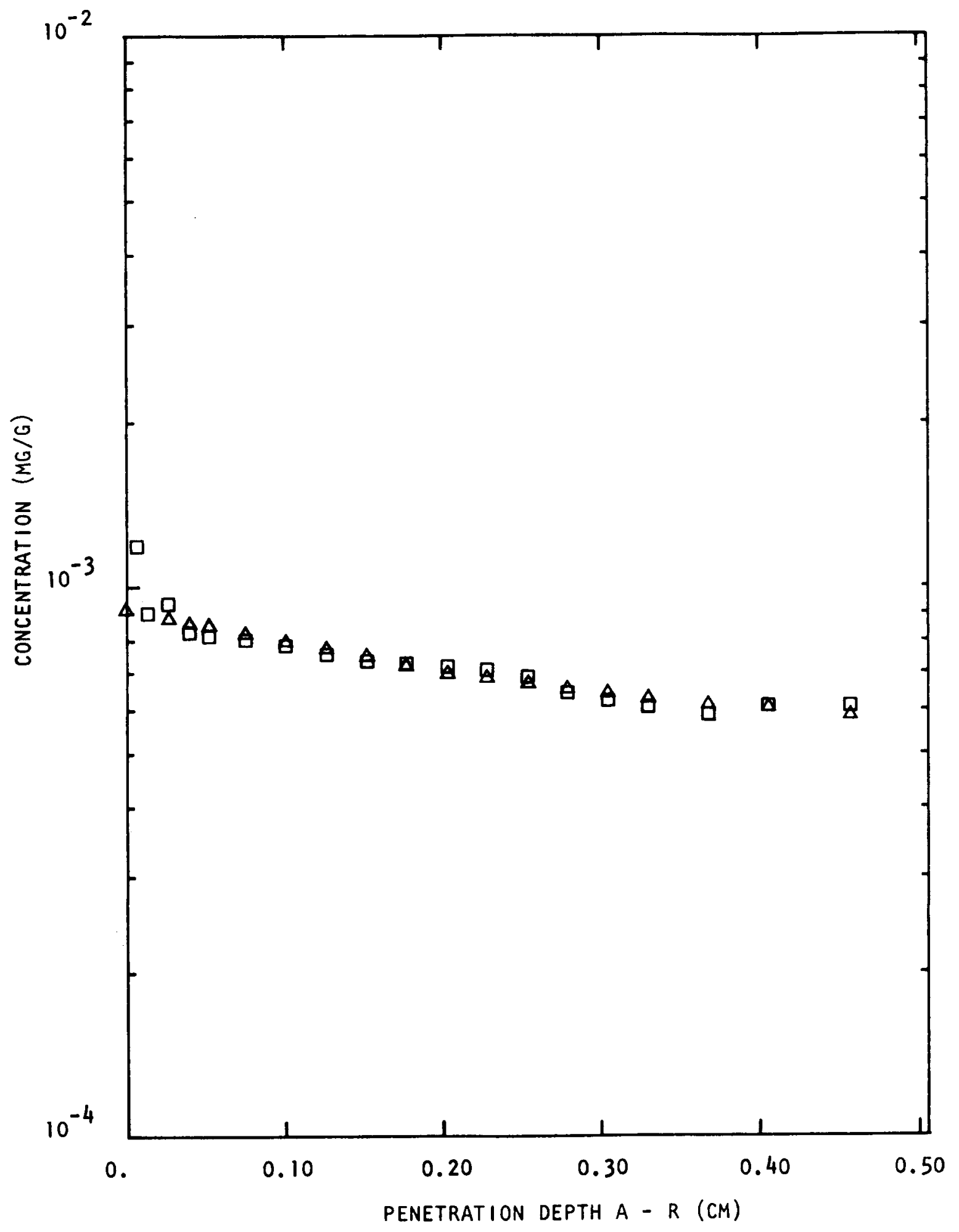

Fig. 70b. FTE-3-66 center post Cs -134 


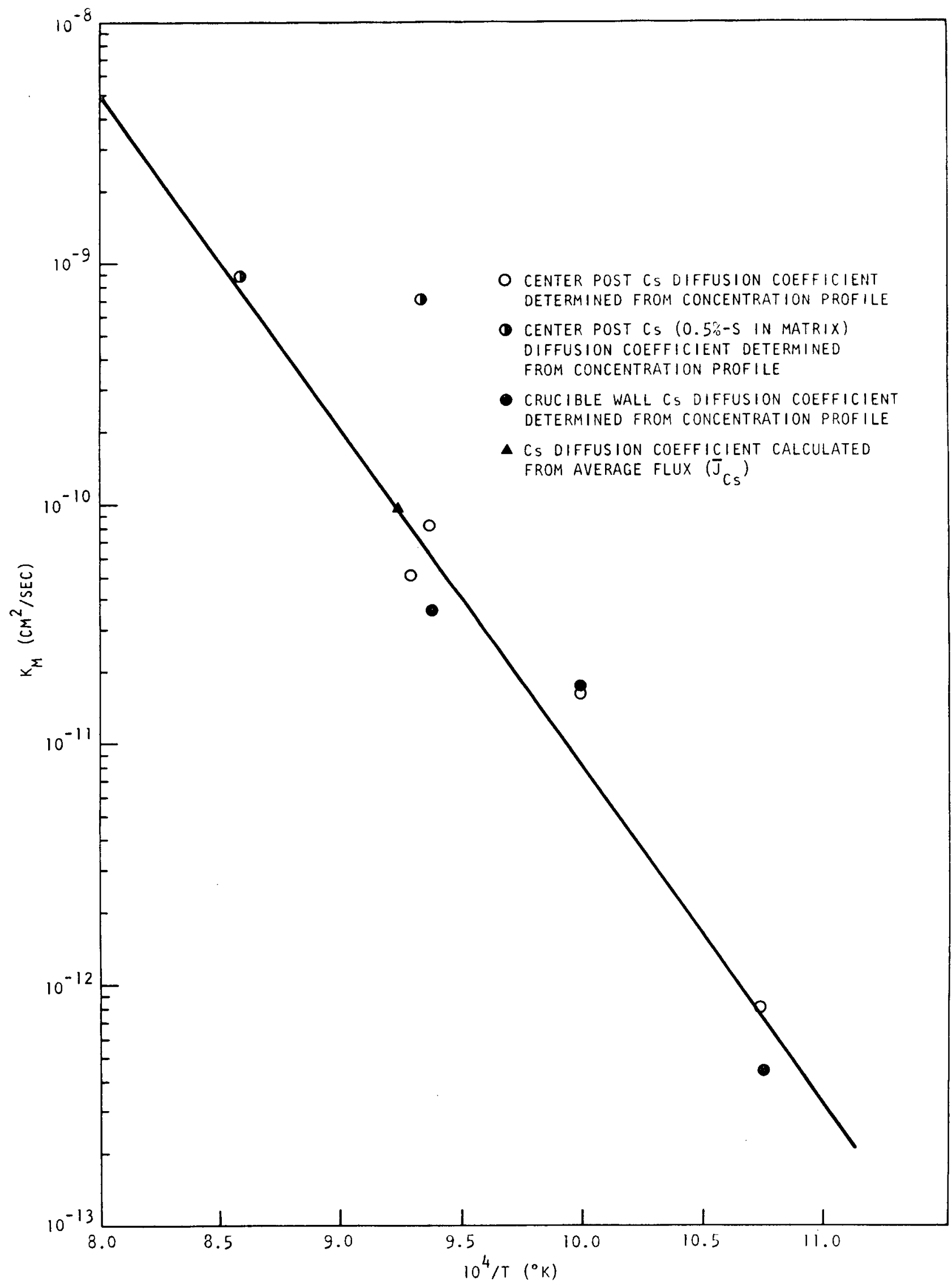

Fig. 71. Cesium fast-component permeation coefficients from FTE-3 diffusion samples 


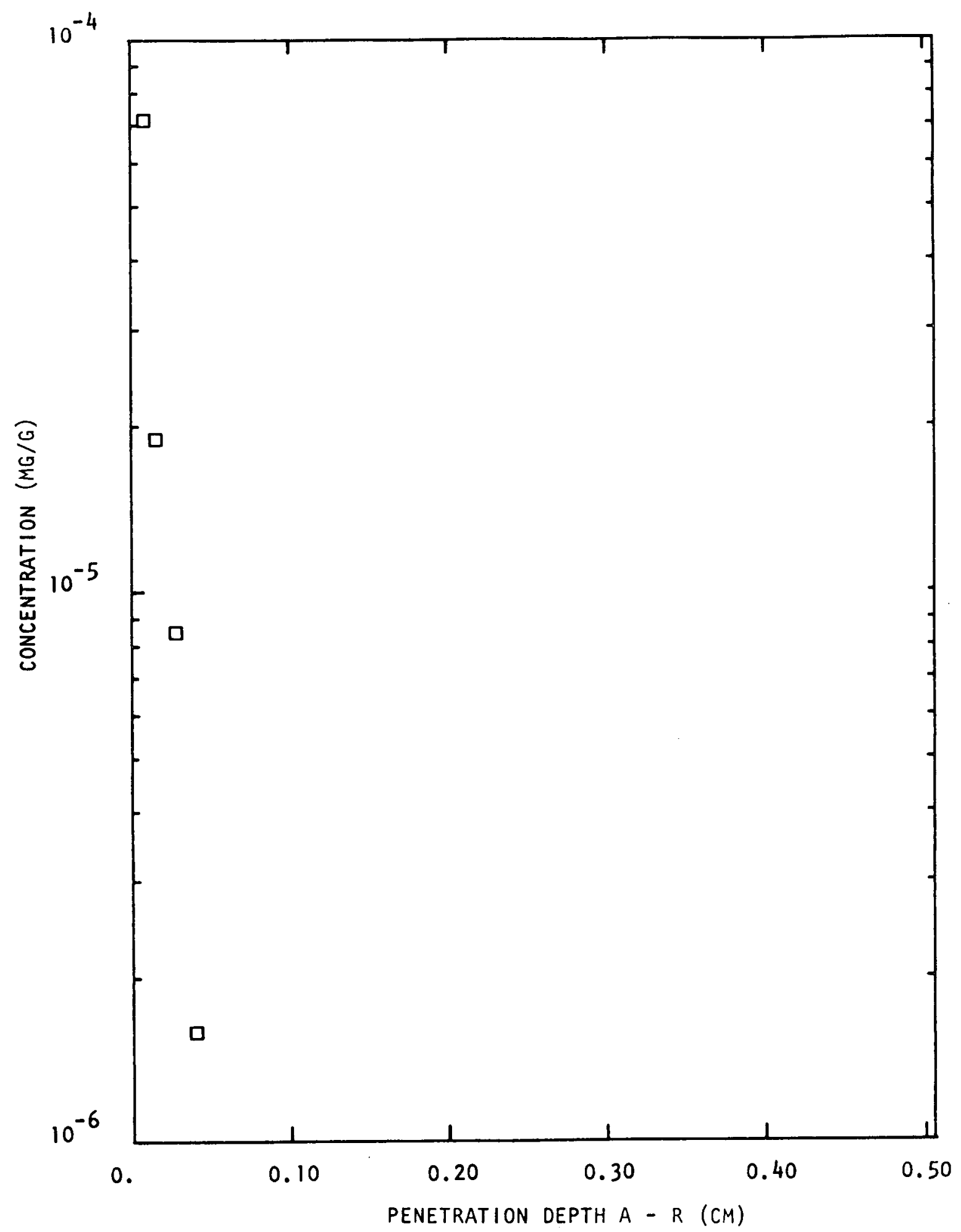

Fig. 72. FTE-3-11 center post $\mathrm{Sr}-85$ 


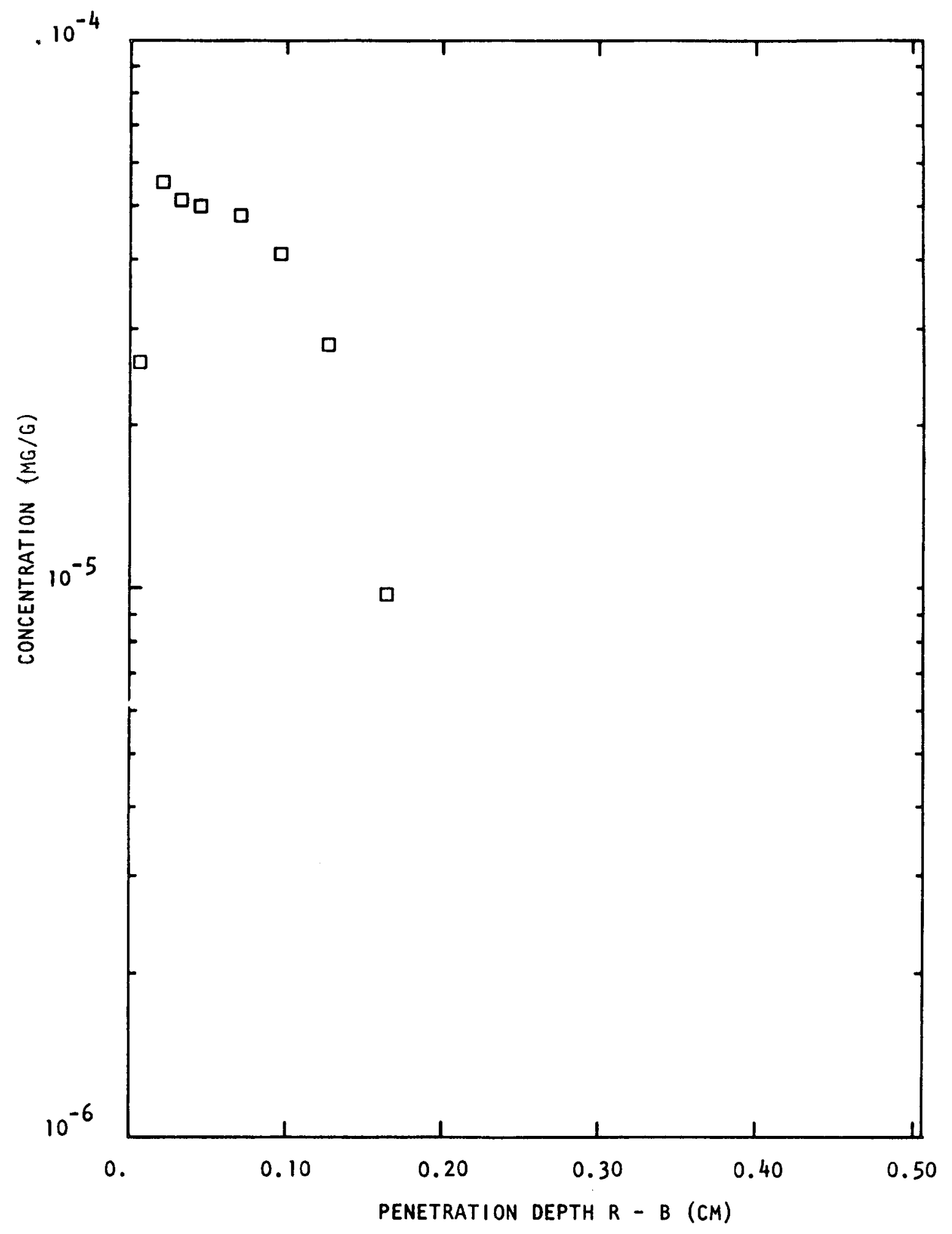

Fig. 73a. FTE-3-16 crucible wall Sr-85 


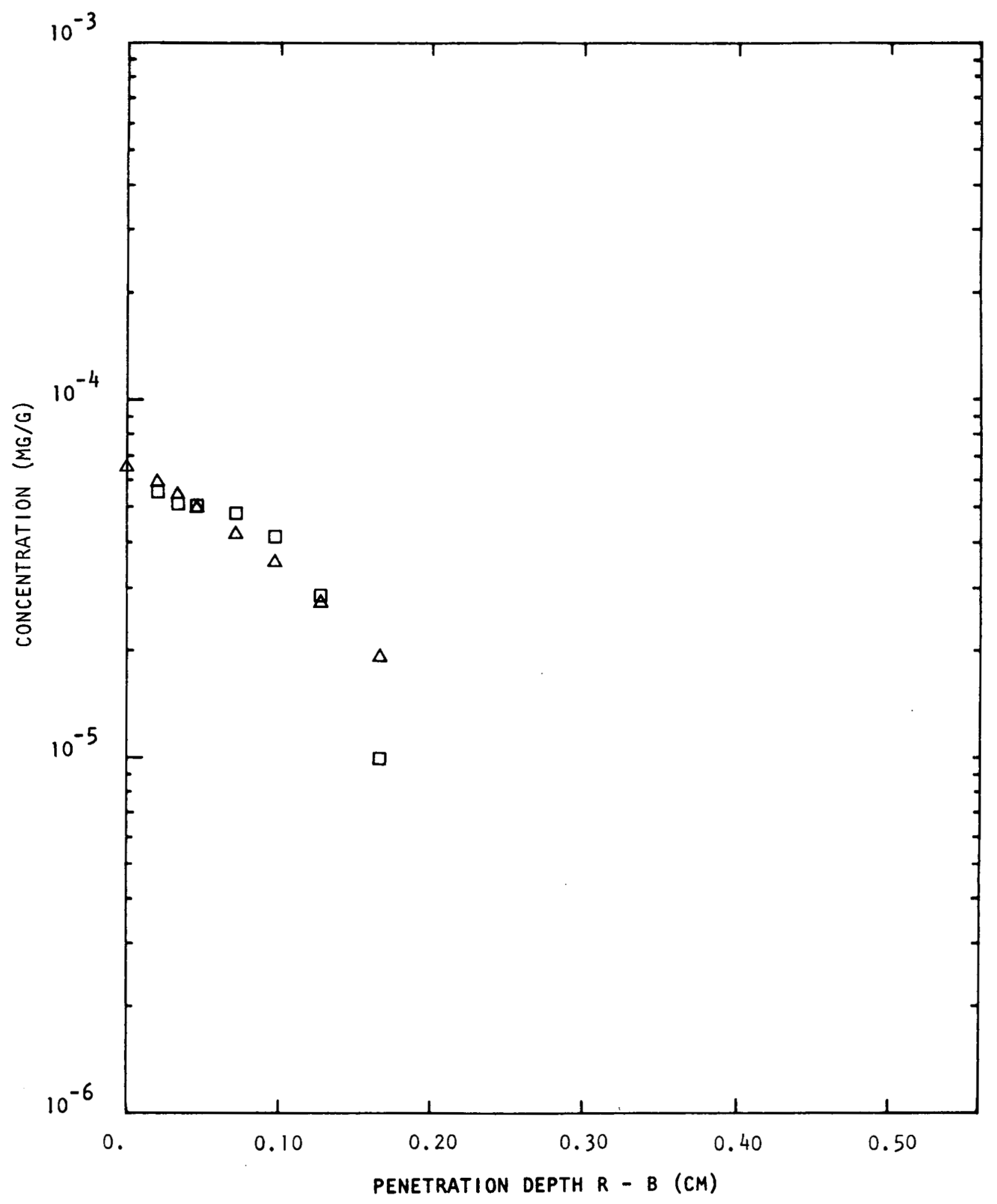

Fig. 73b. FTE-3-16 crucible wall Sr-85 


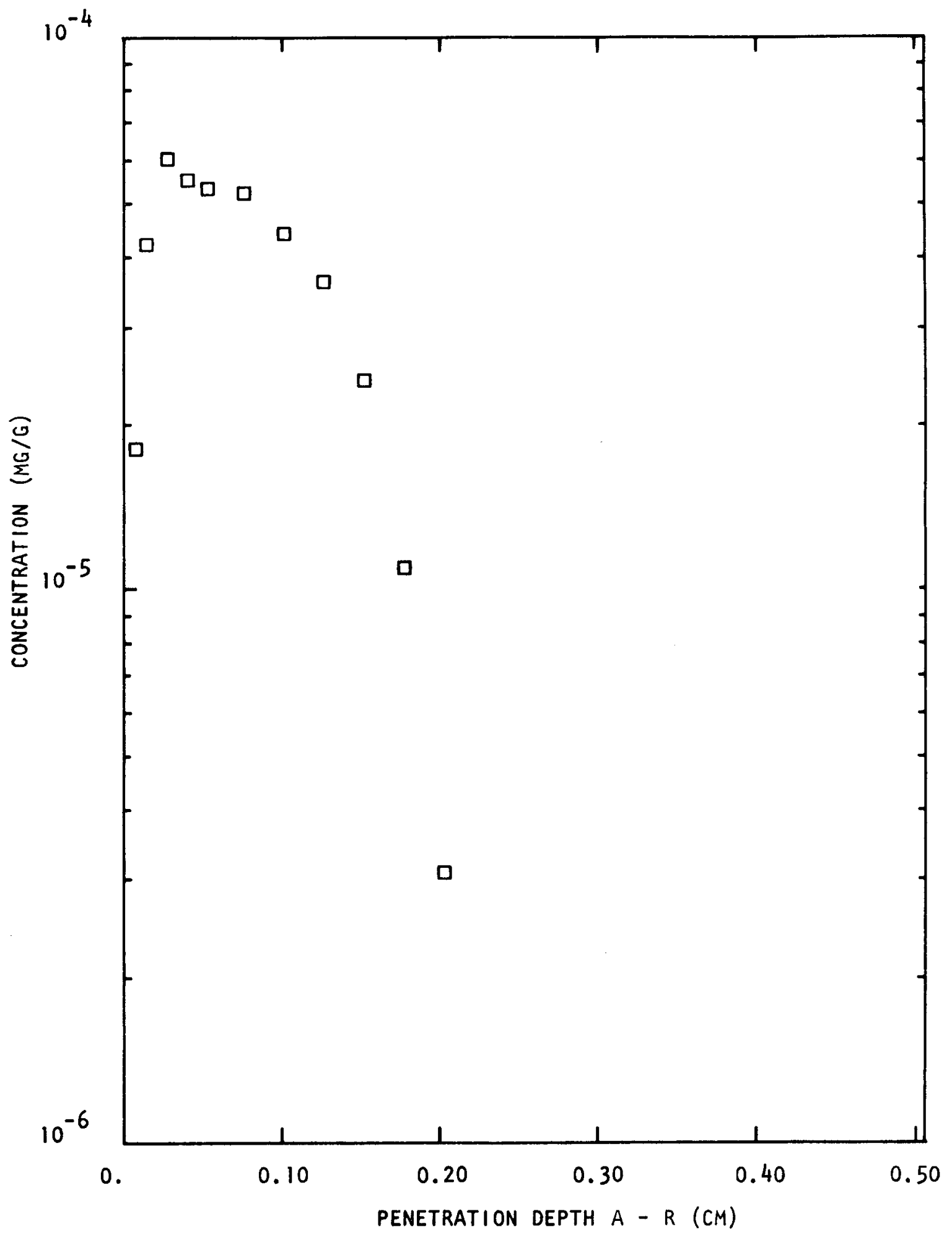

Fig. 74a. FTE-3-16 center post $\mathrm{Sr}-85$ 


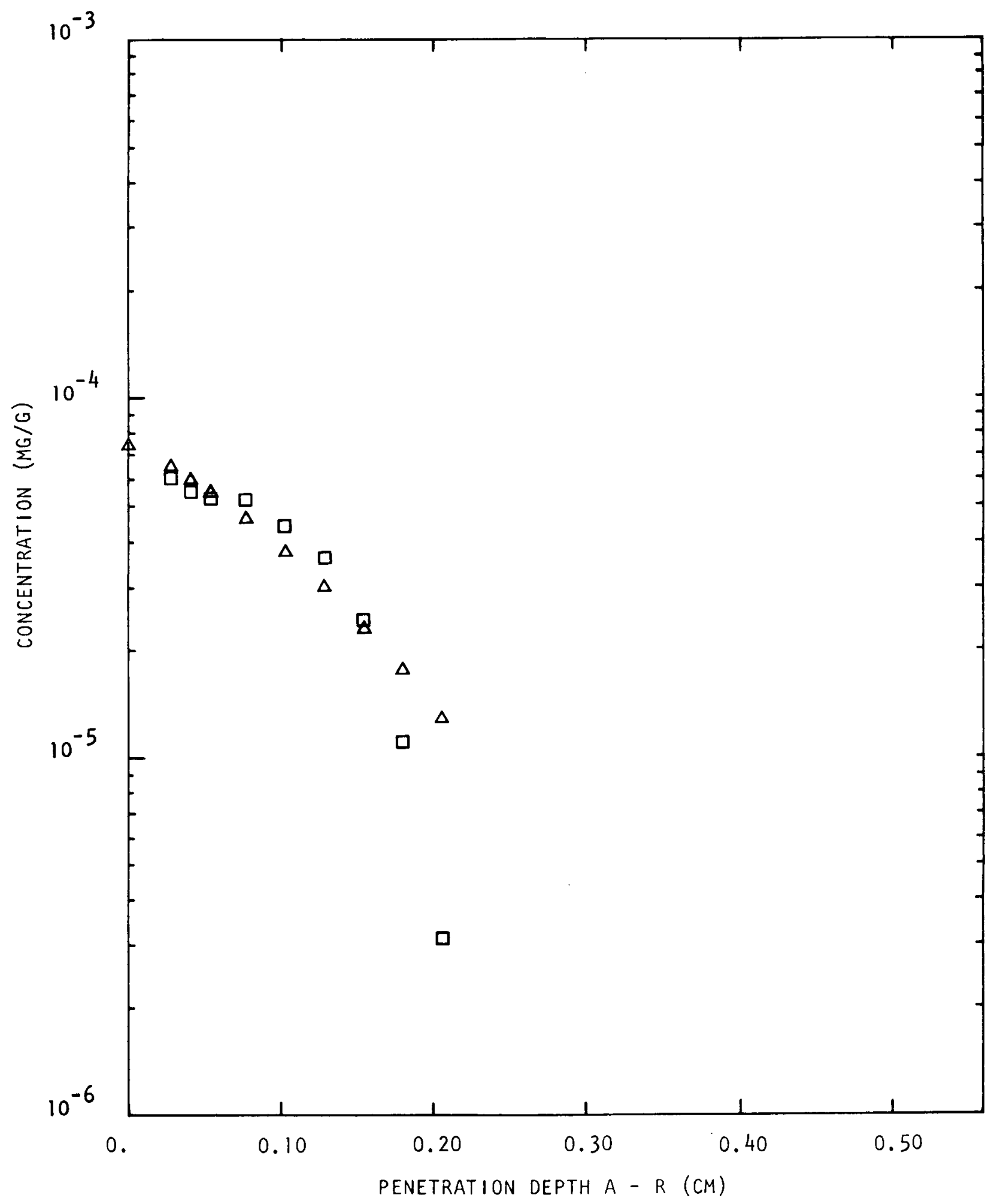

Fig. 74b. FTE-3-16 center post $\mathrm{Sr}-85$ 


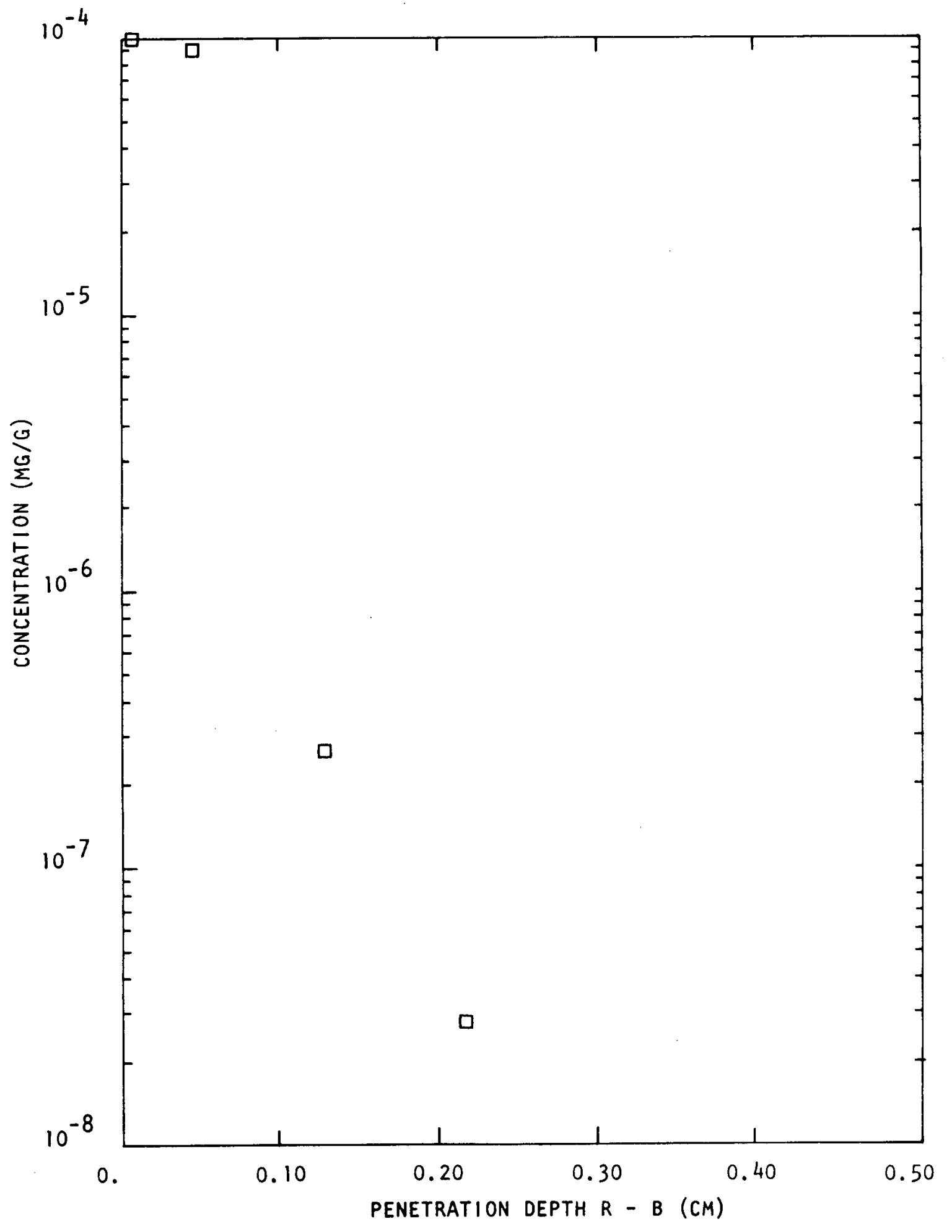

Fig. 75. FTE-3-42 crucible wall Sr-85 


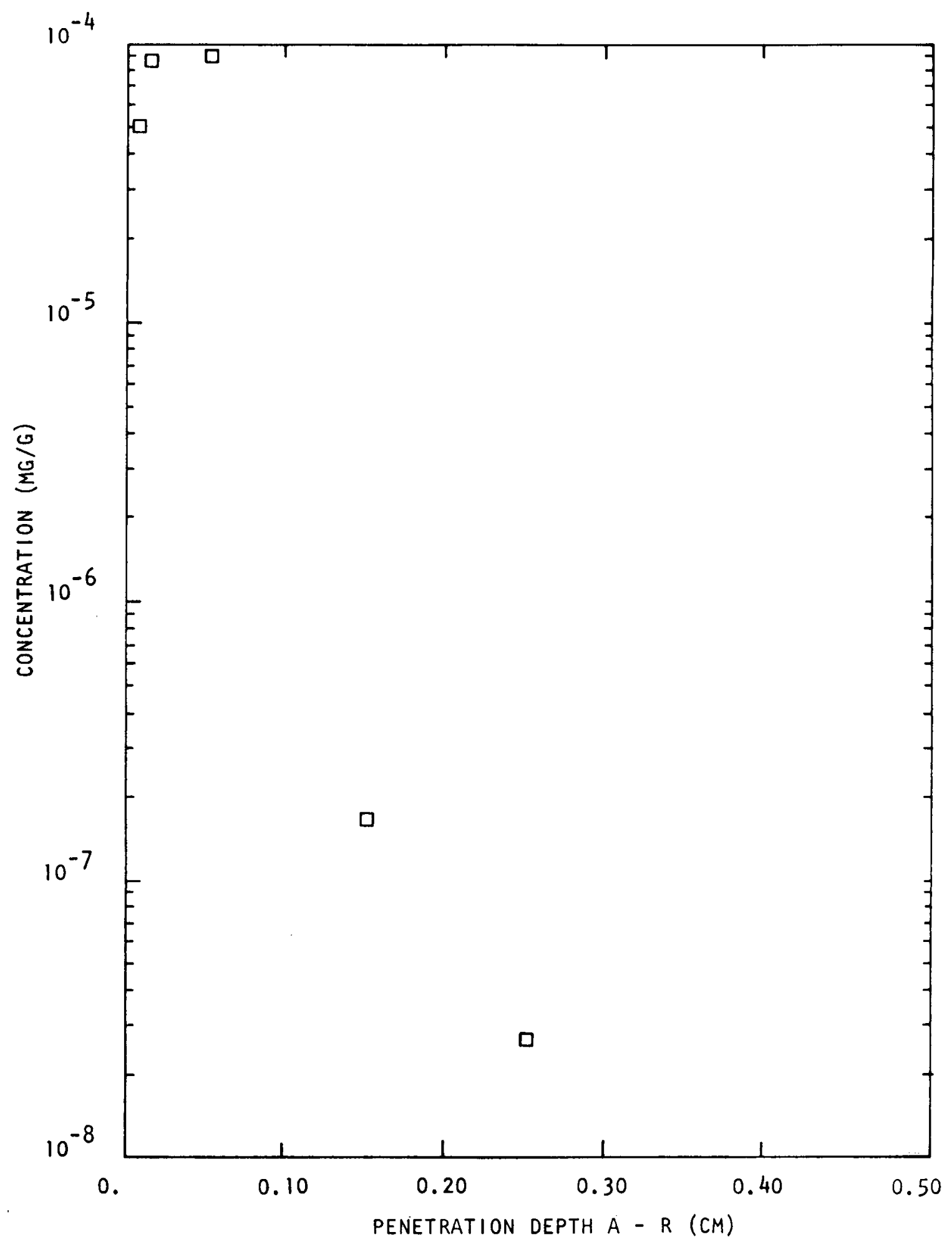

Fig. 76. FTE-3-42 center post $\mathrm{Sr}-85$ 


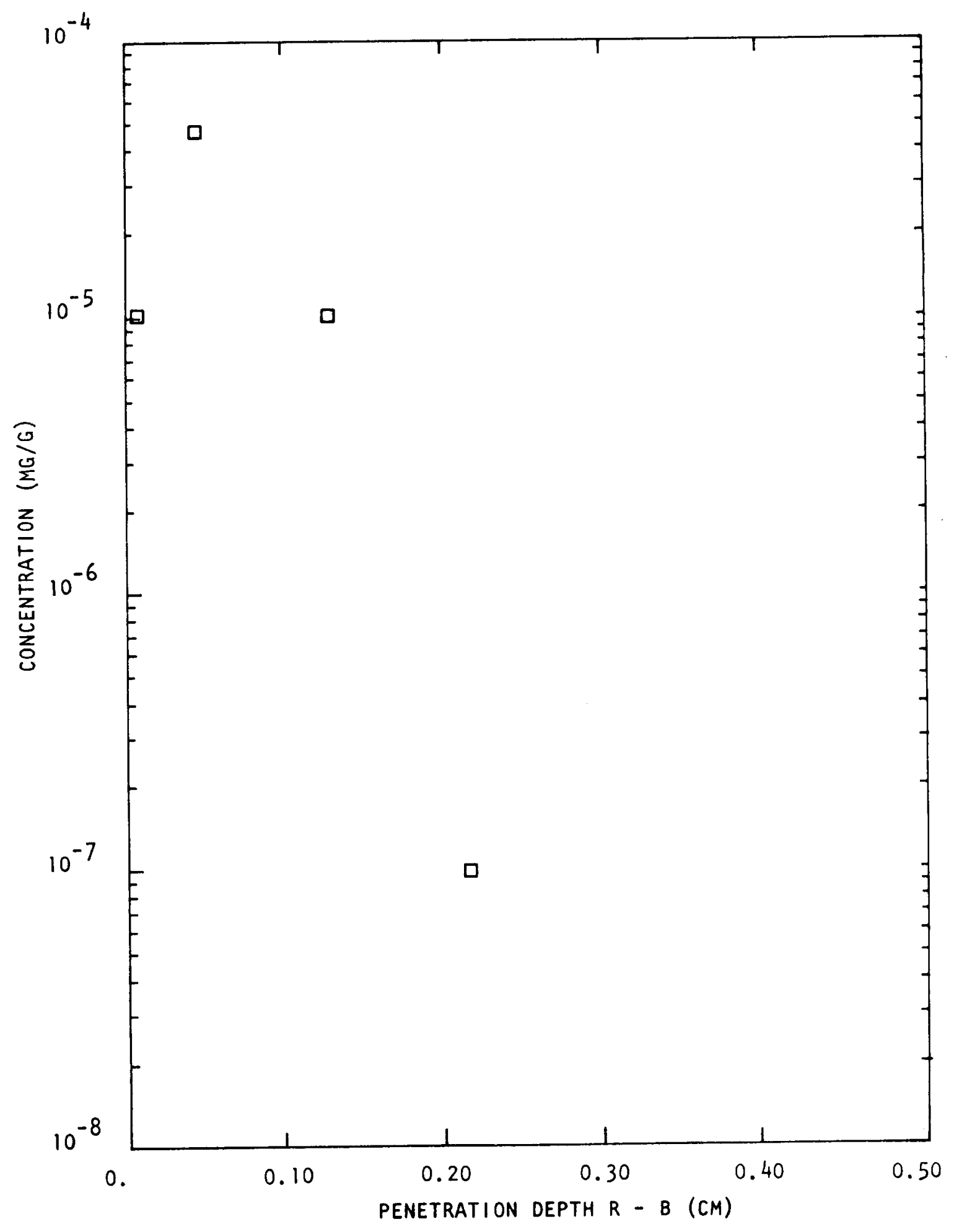

Fig. 77. FTE-3-45 crucible wall $\mathrm{Sr}-85$ 


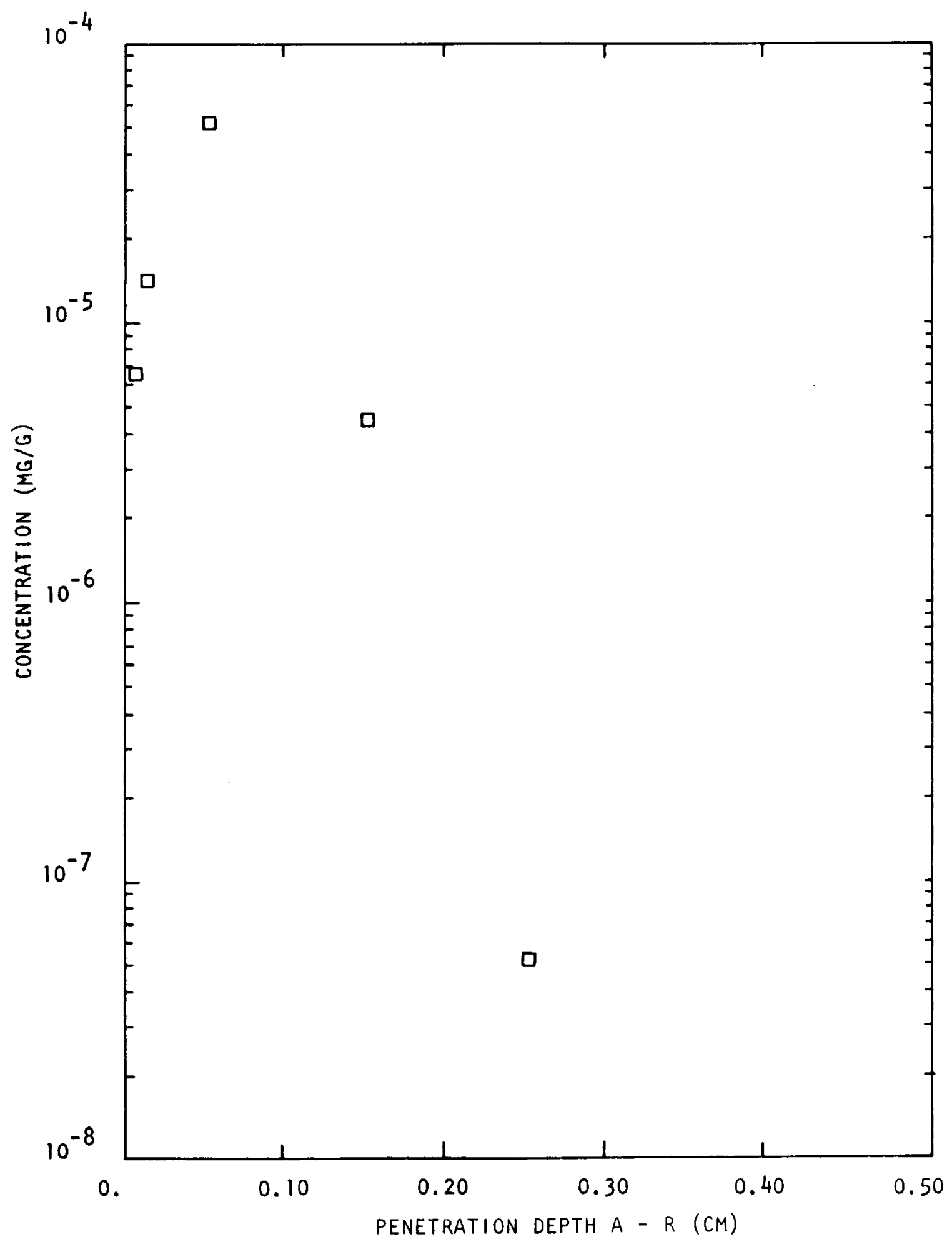

Fig. 78. FTE-3-45 center post $\mathrm{Sr}-85$ 


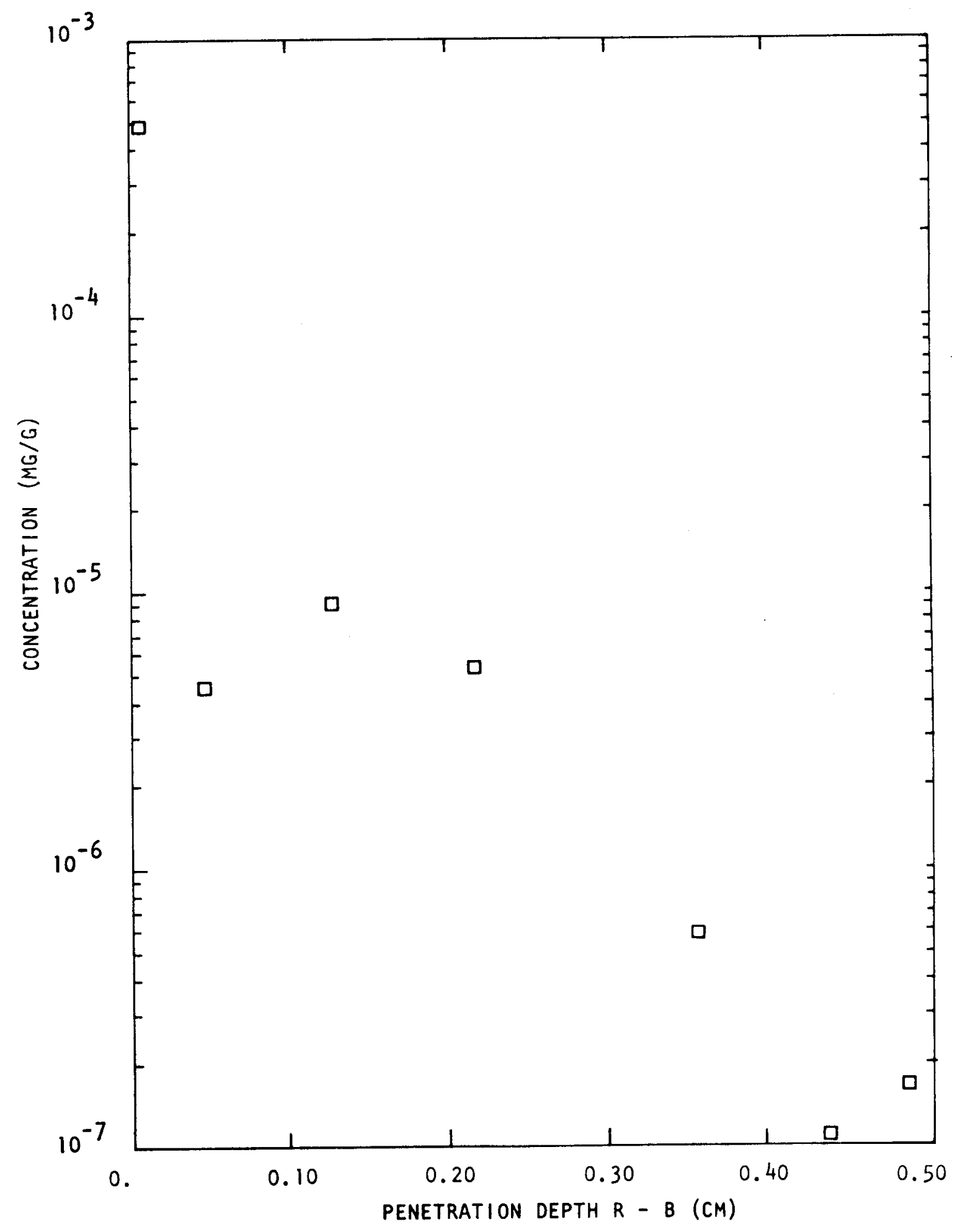

Fig. 79. FTE-3-55 crucible wall Sr-85 


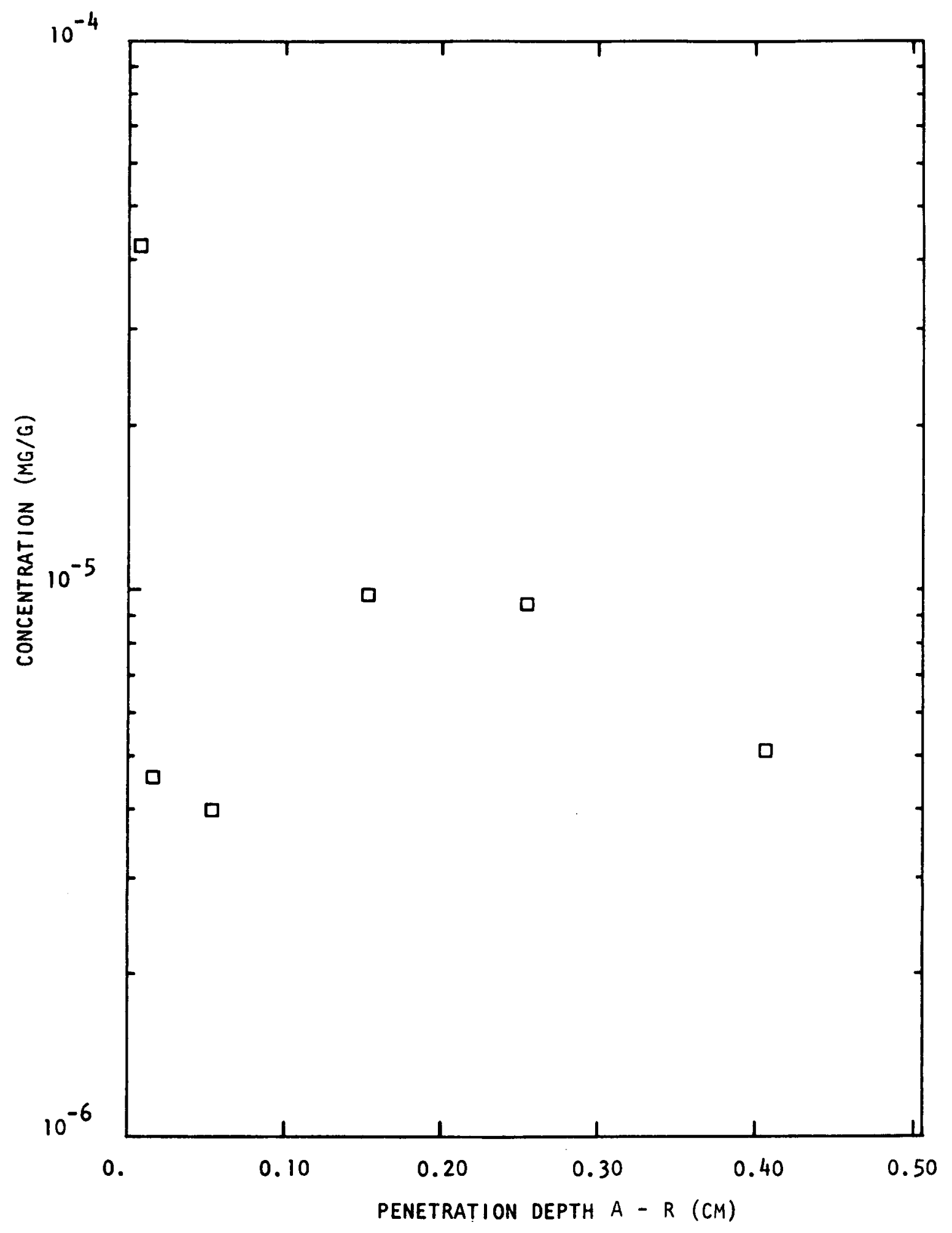

Fig. 80. FTE-3-55 center post Sr-85 


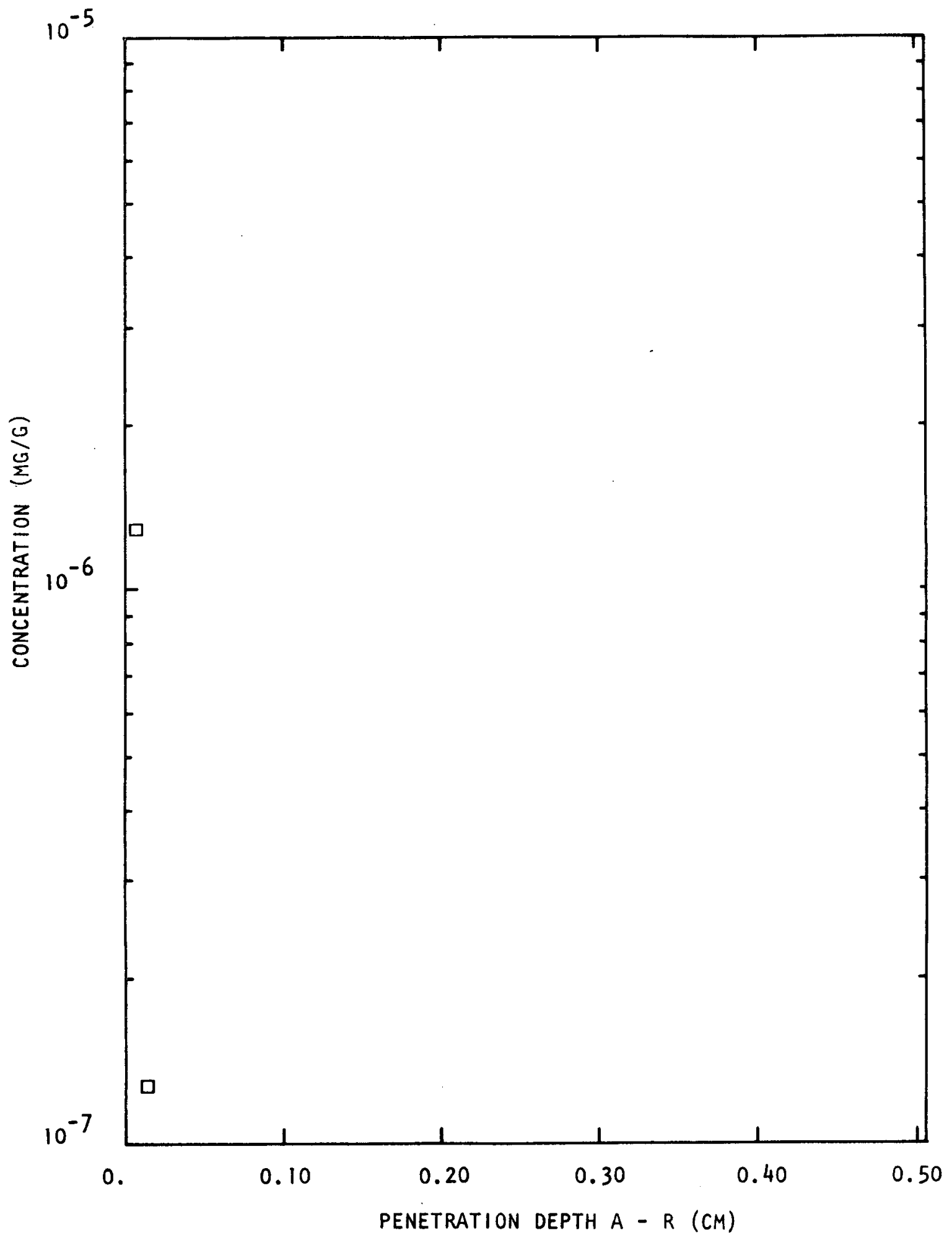

Fig. 81. FTE-3-63 center post Sr-85 


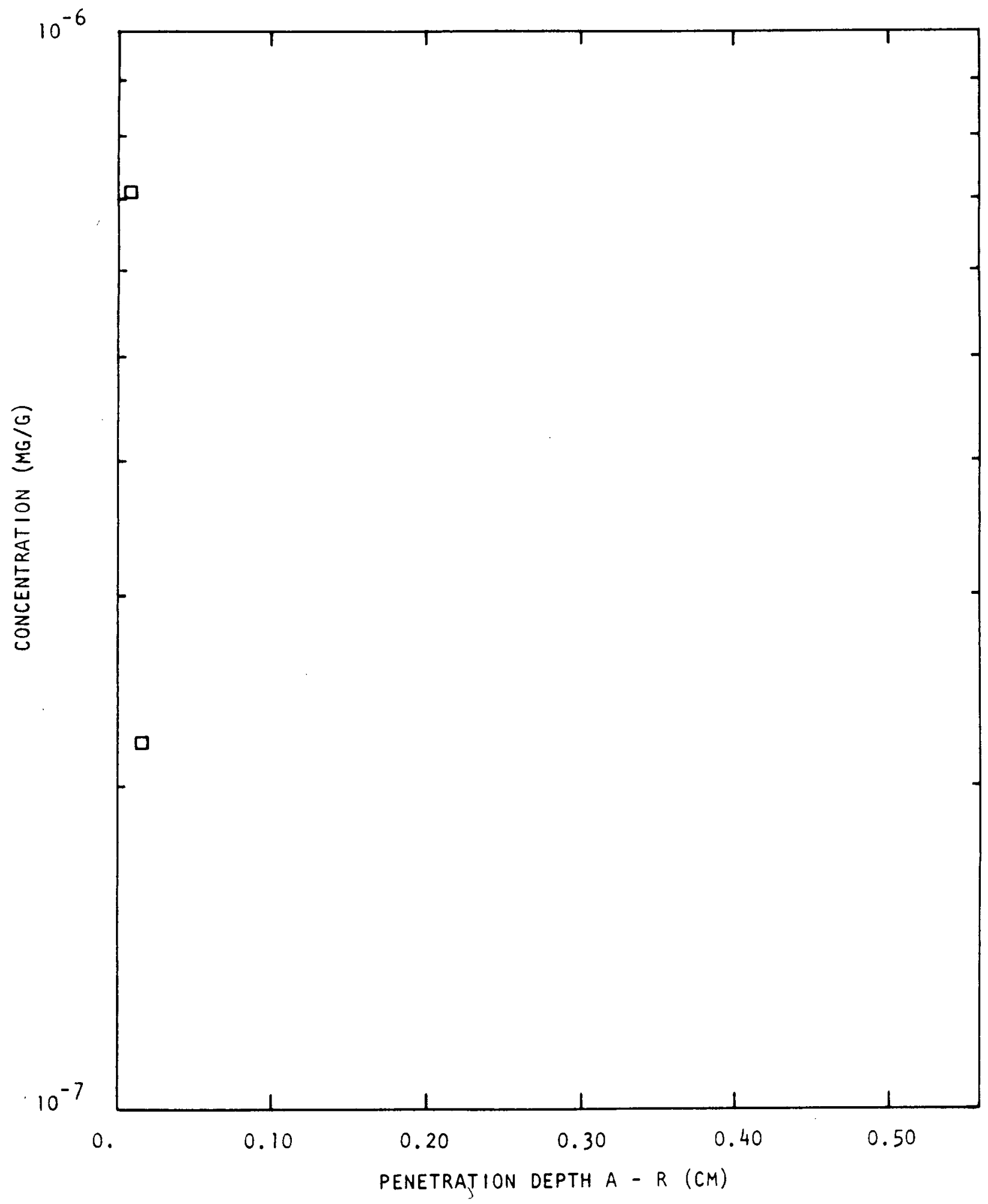

Fig. 82. FTE-3-66 center post $\mathrm{Sr}-85$ 


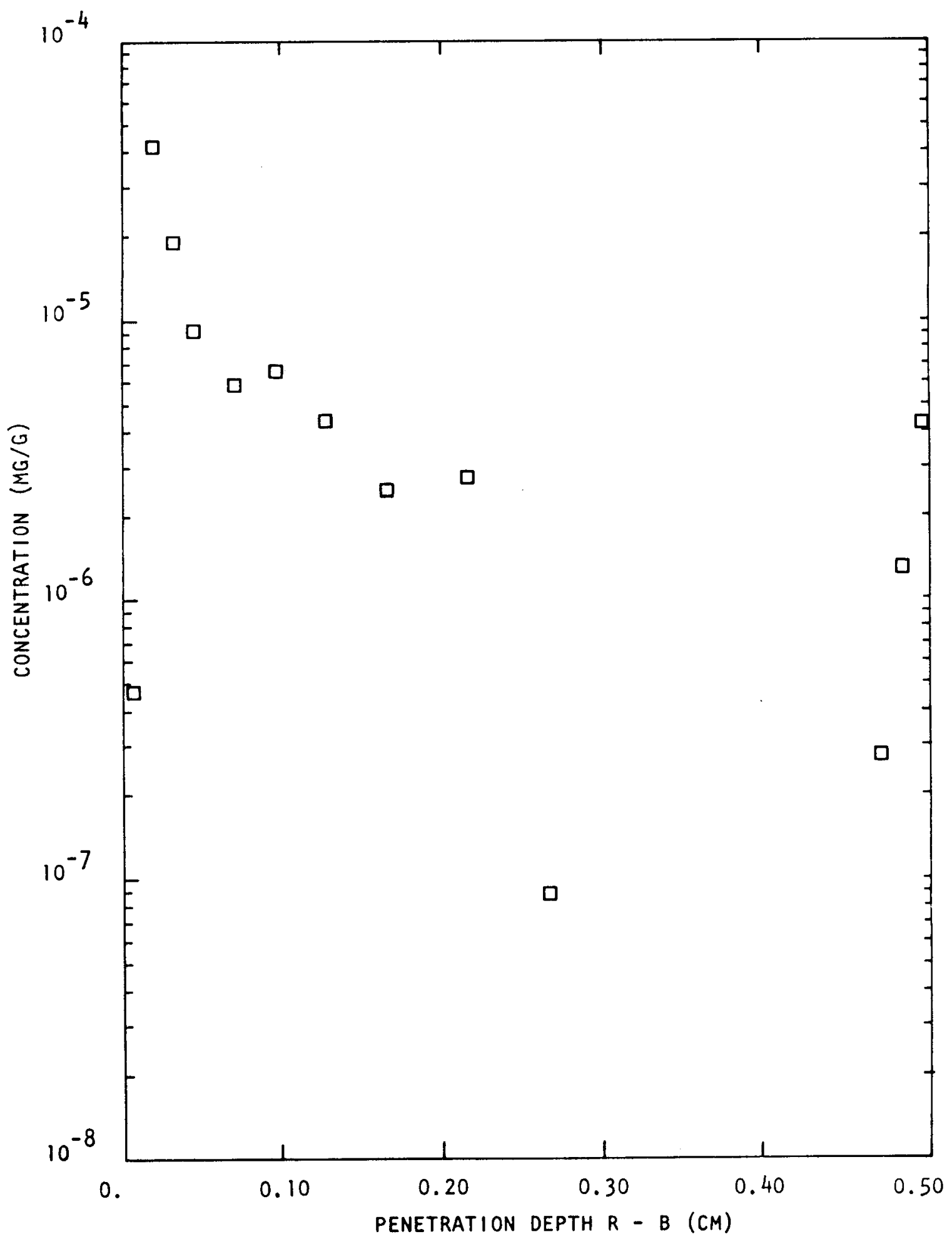

Fig. 83. FTE-3-24 crucible wall Eu-154 


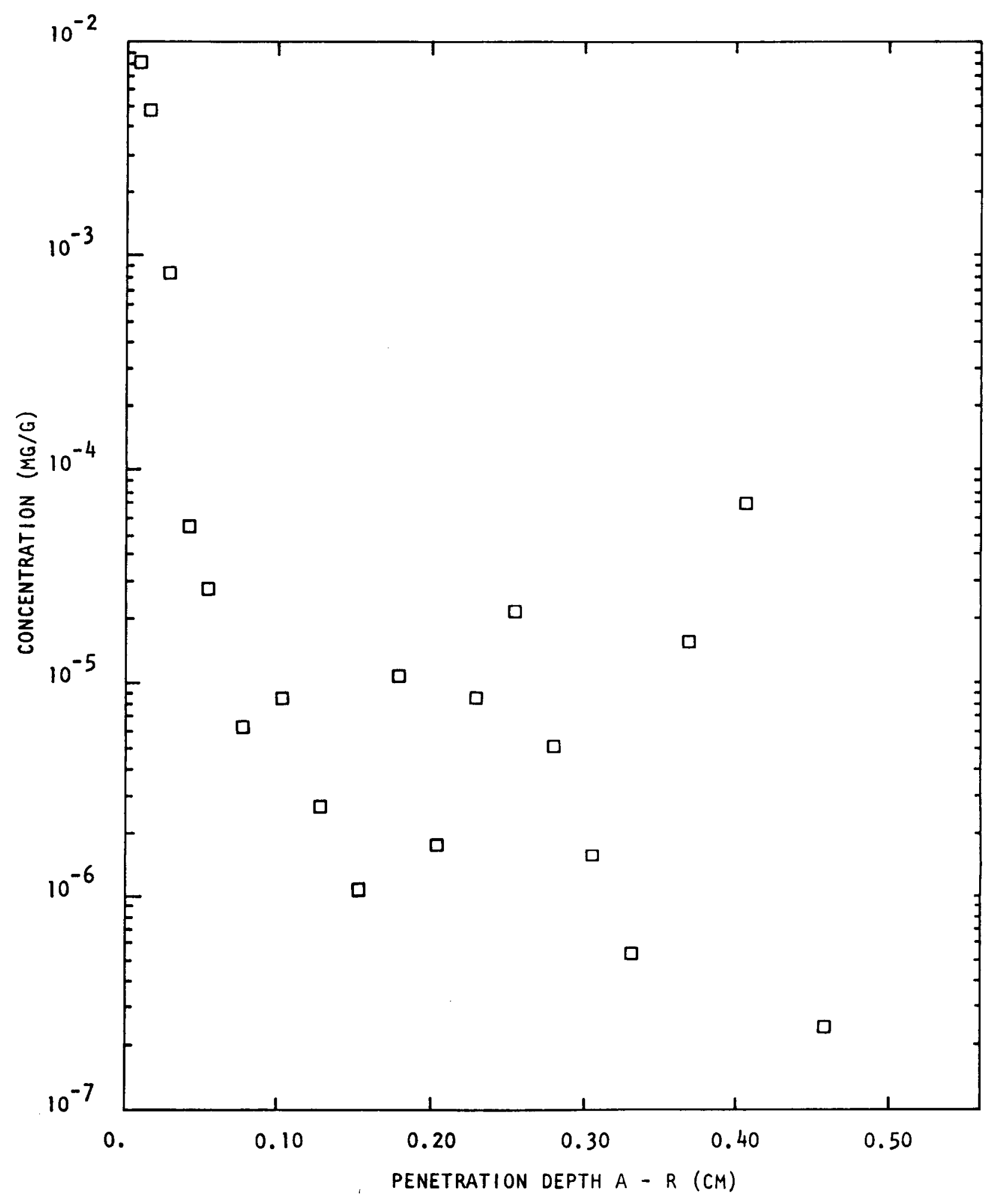

Fig. 84. FTE-3-24 center post Eu-154 


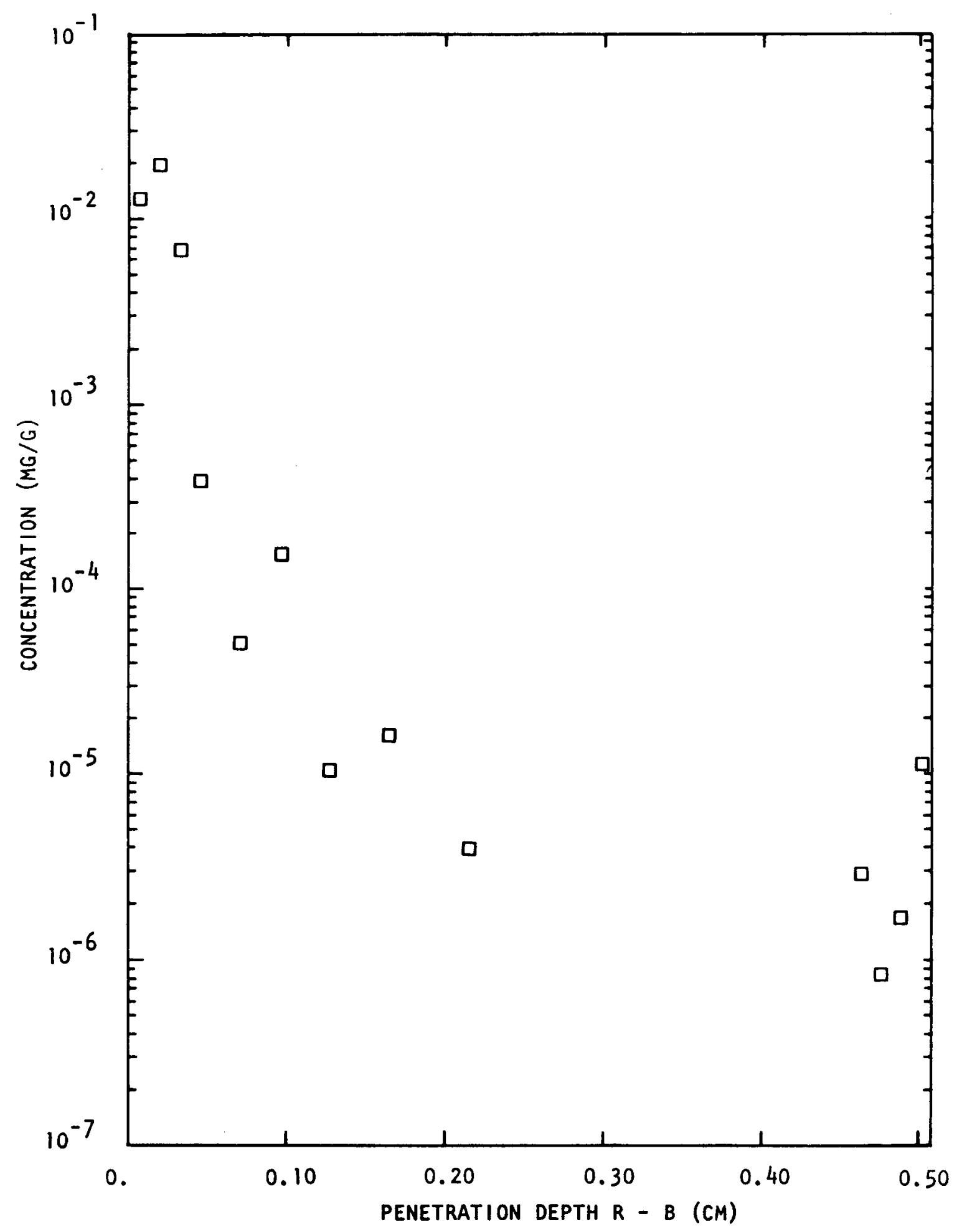

Fig. 85. FTE-3-42 crucible wa11 Eu-154 


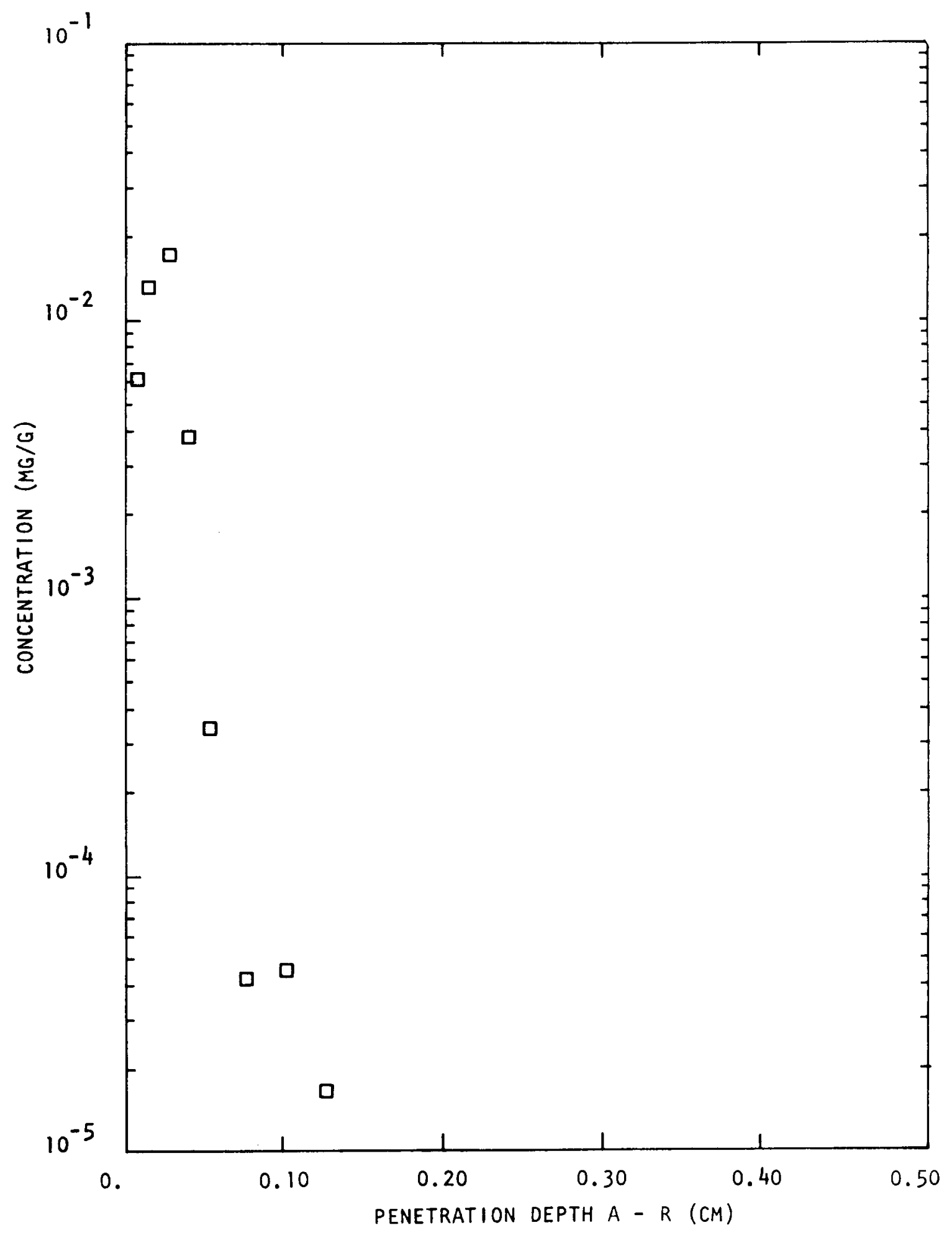

Fig. 86. FTE-3-42 center post Eu-154 


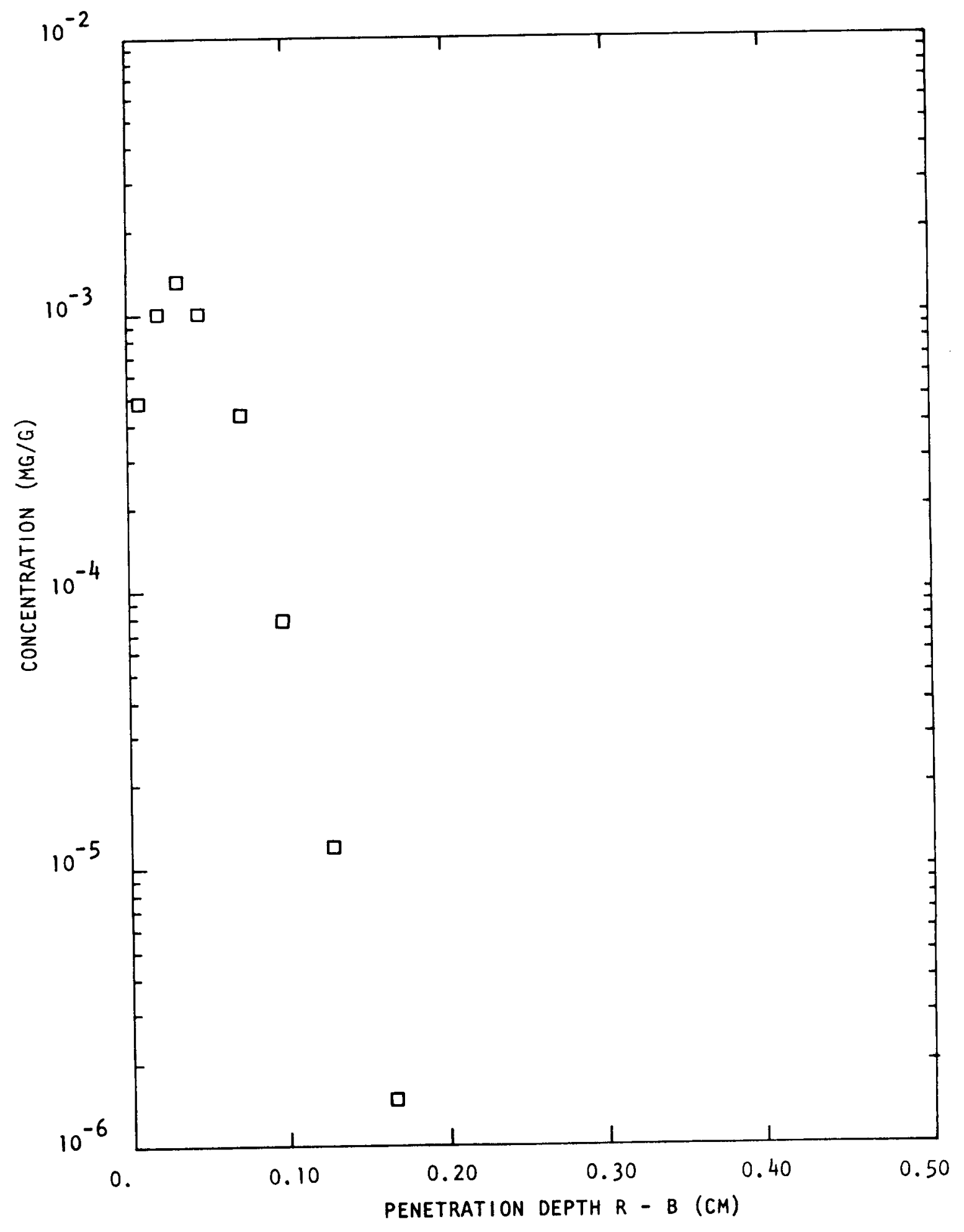

Fig. 87a. FTE-3-45 crucible wa11 Eu-154 


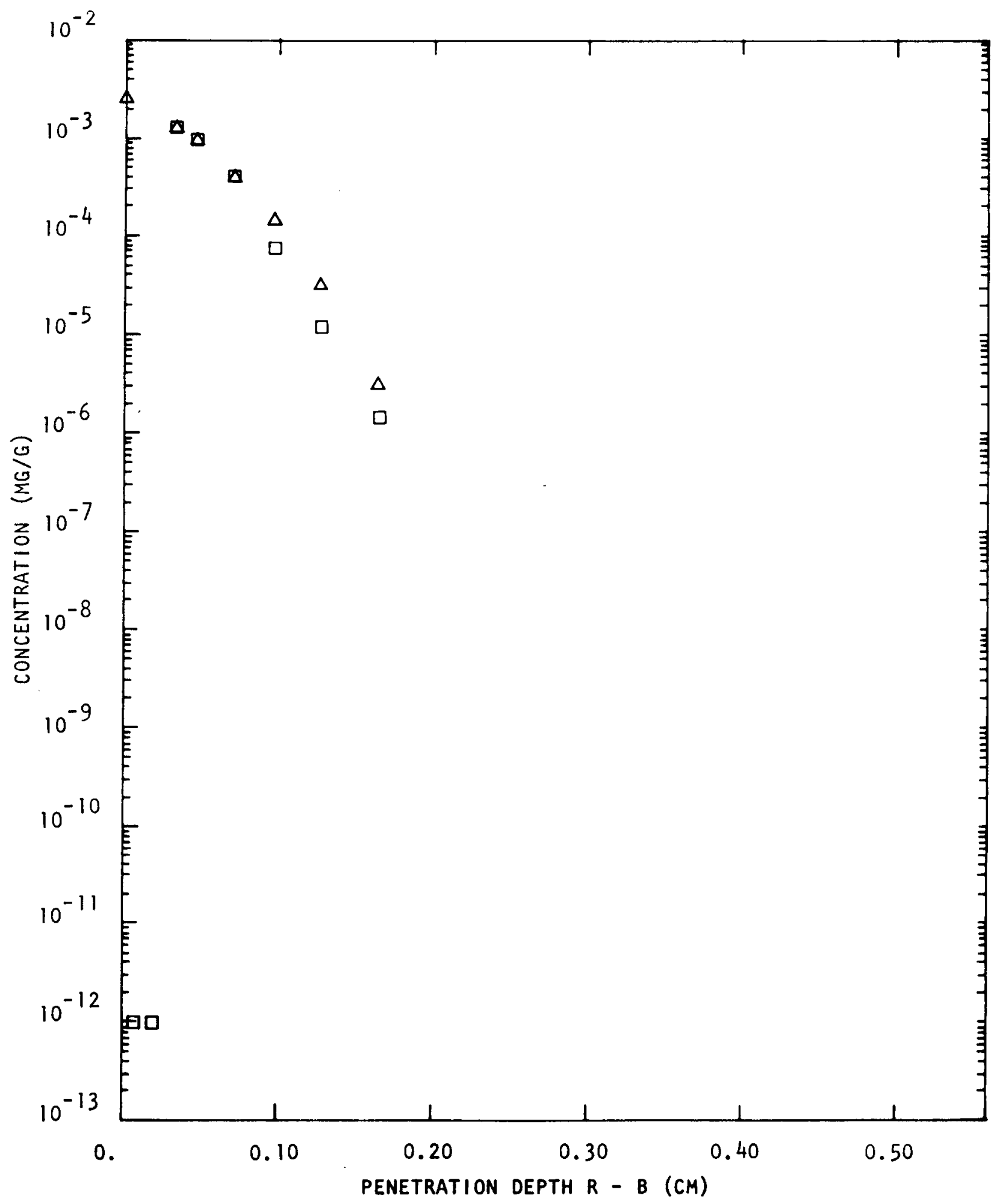

Fig. 87b. FTE-3-45 crucible wall Du-154 


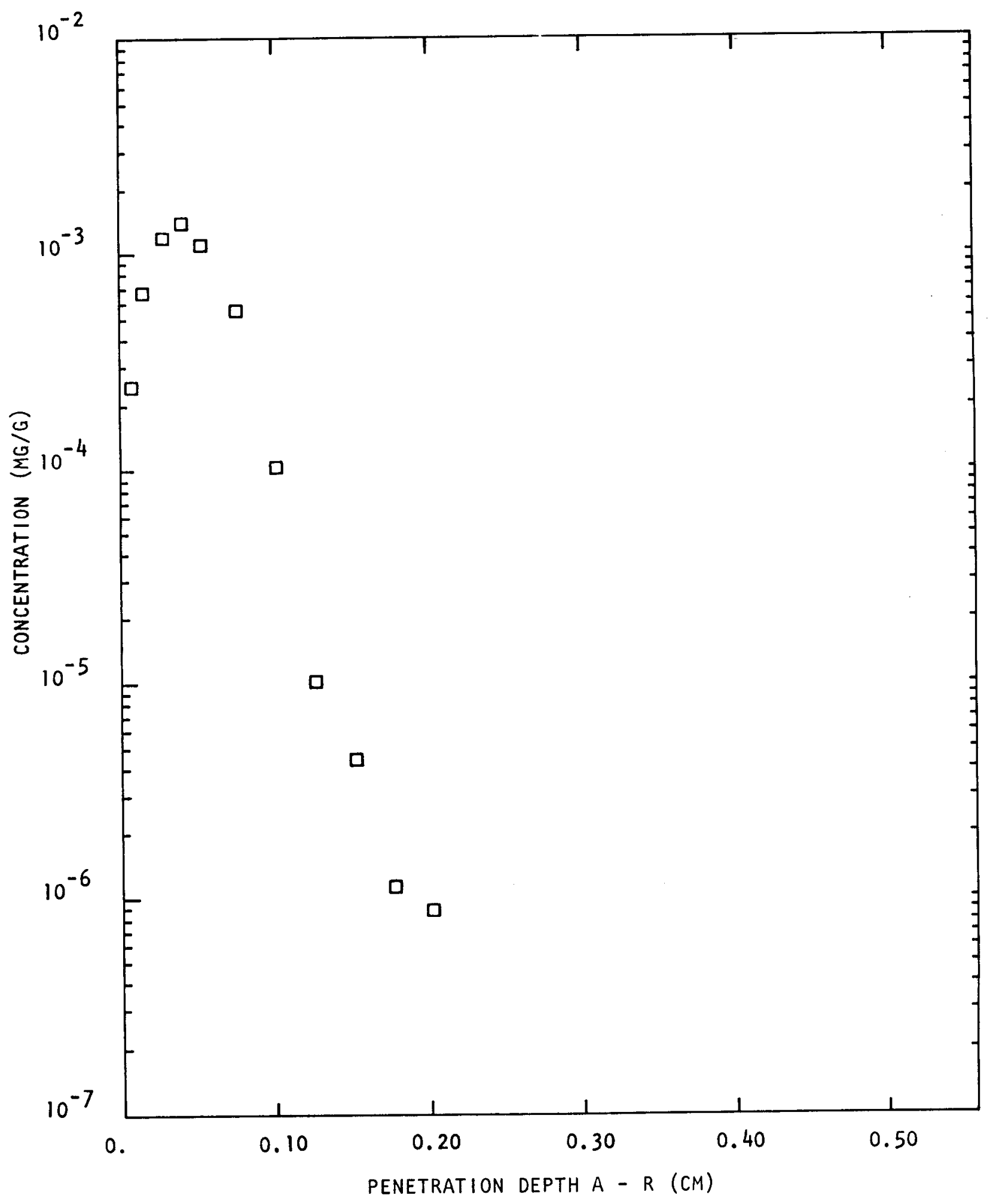

Fig. 88a. FTE-3-45 center post Eu-154 


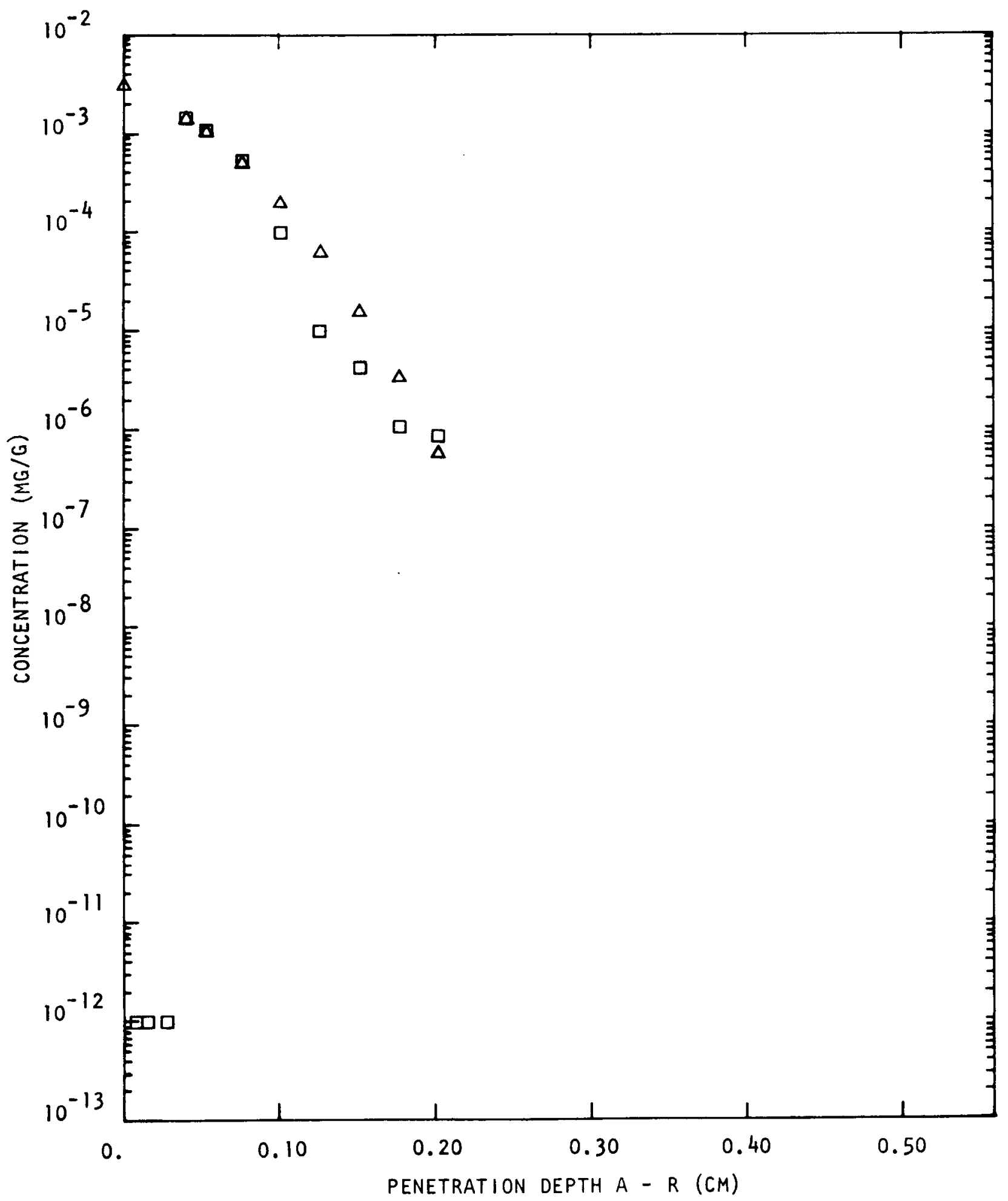

Fig. 88b. FTE-3-45 center post Eu-154 


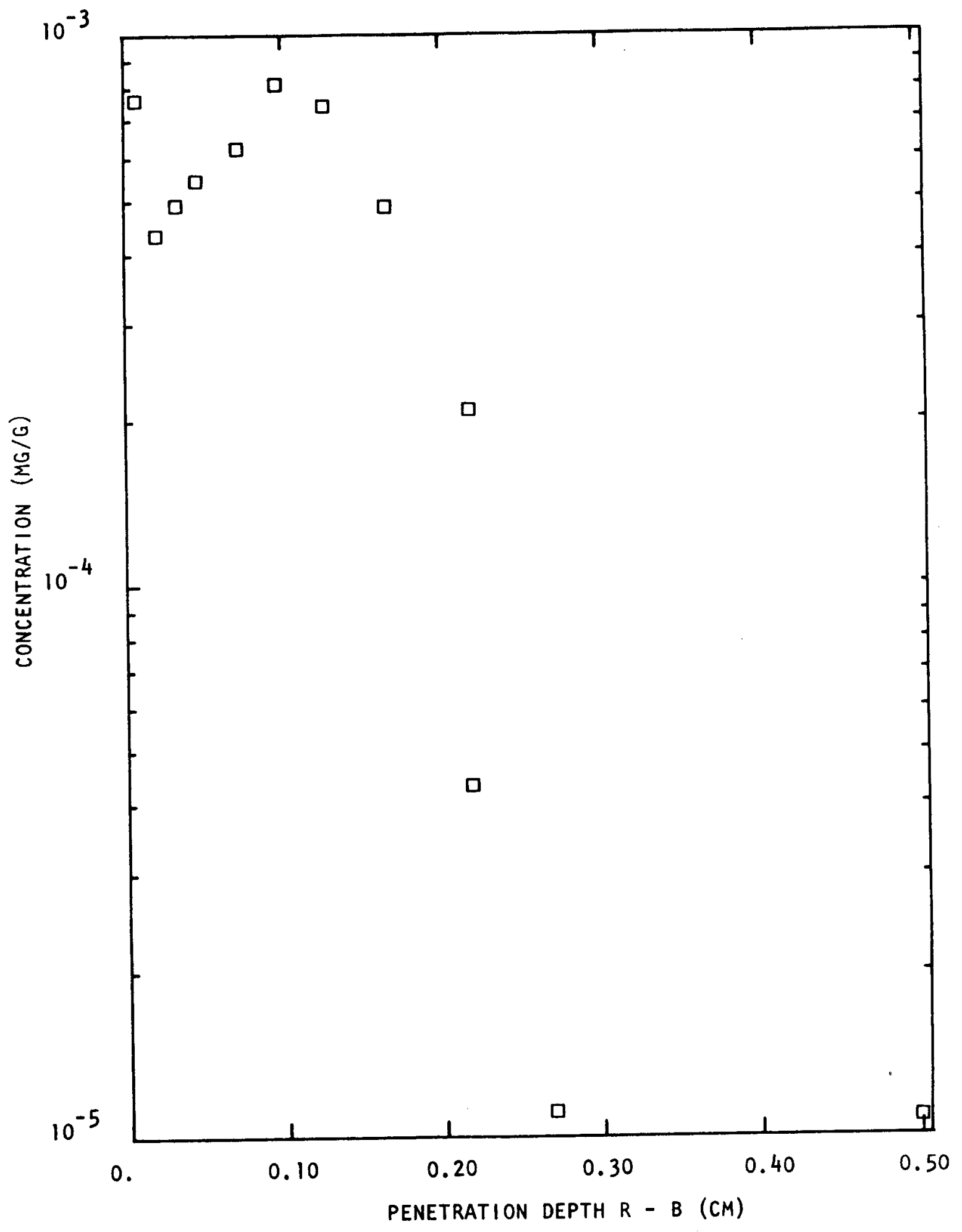

Fig. 89. FTE-3-55 crucible wall Eu-154 


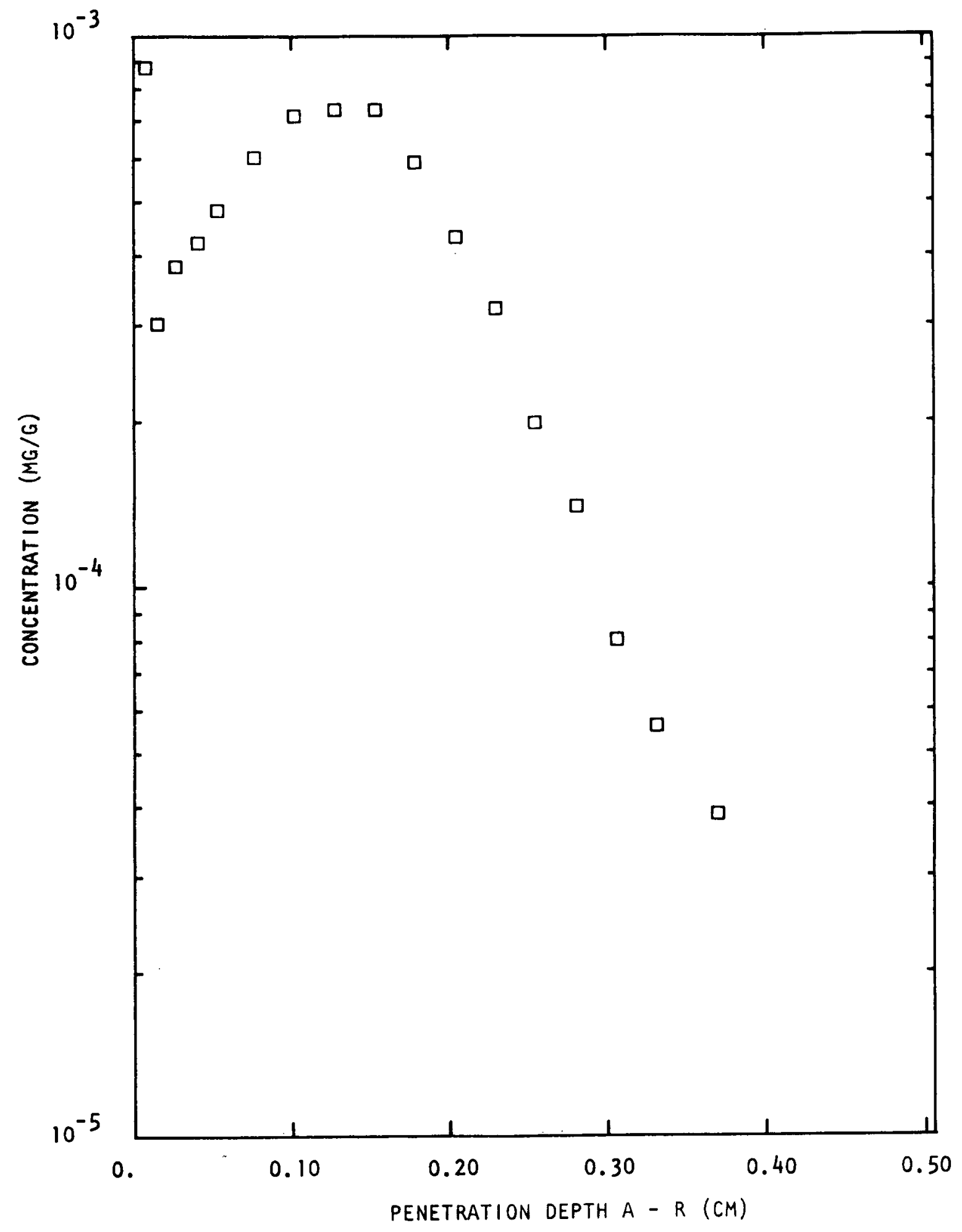

Fig. 90. FTE-3-55 center post Eu-154 


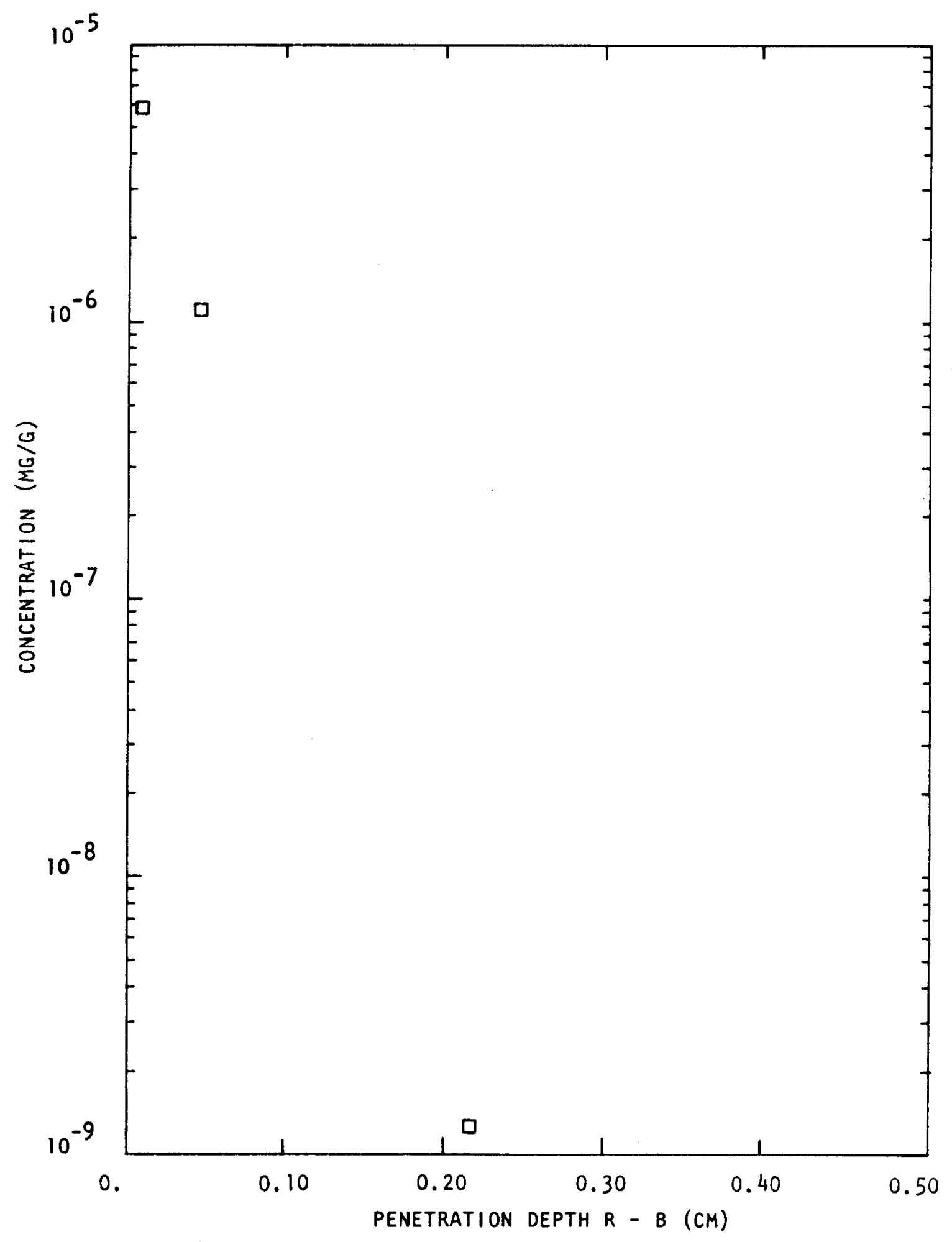

Fig. 91. FTE-3-42 crucible wall Ba-133 


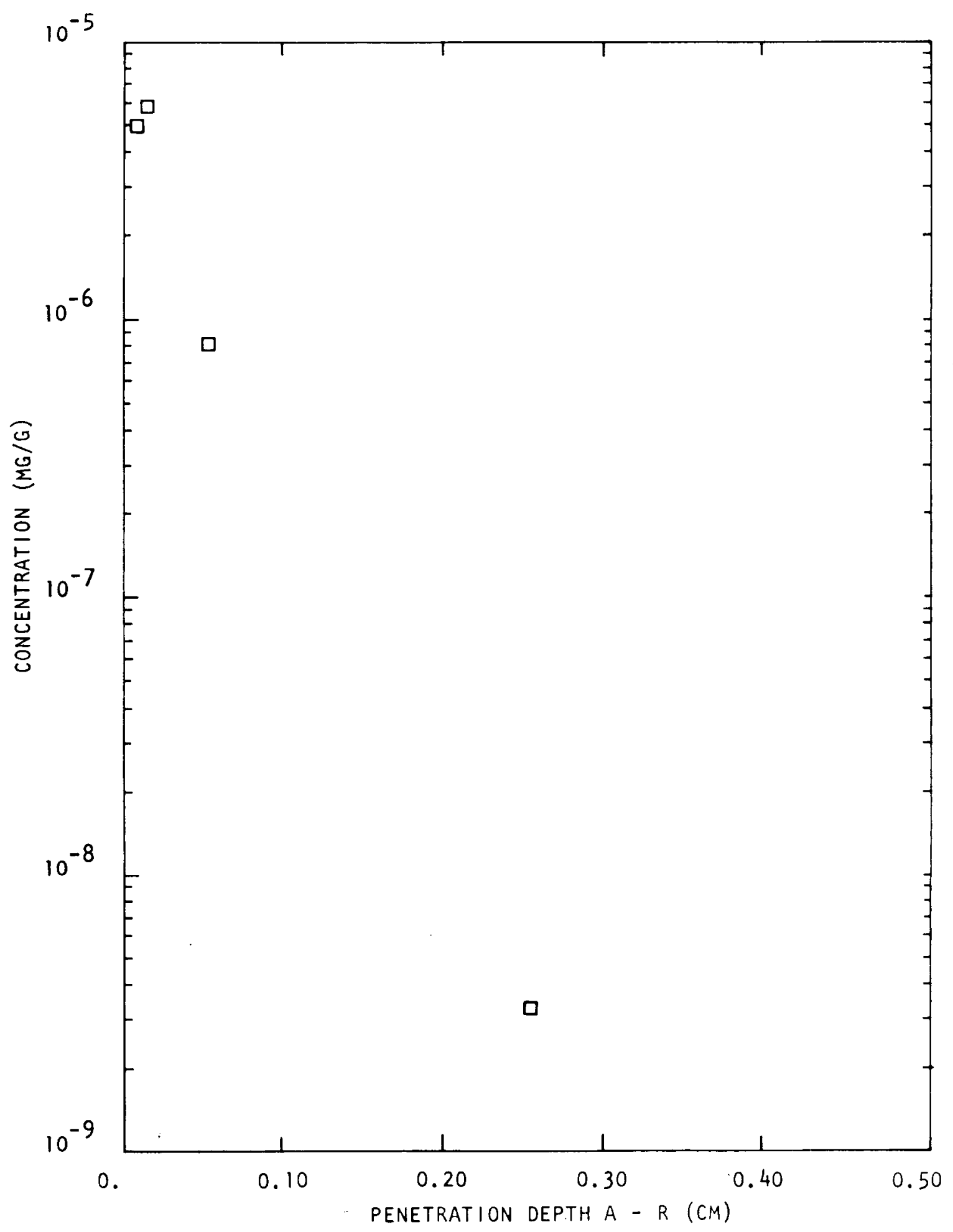

Fig. 92. FTE-3-42 center post $\mathrm{Ba}-133$ 


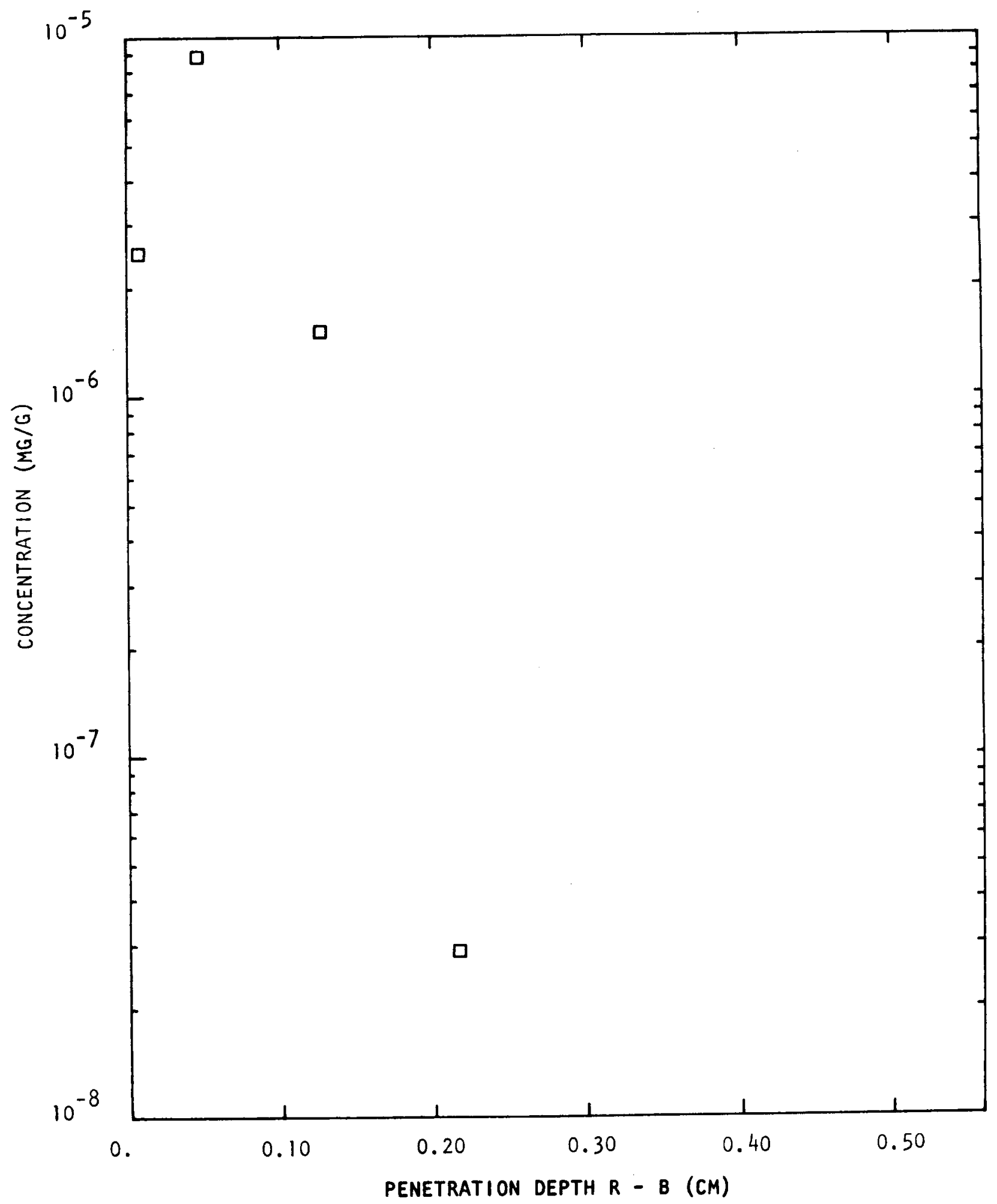

Fig. 93a. FTE-3-45 crucible wall Ba-133 


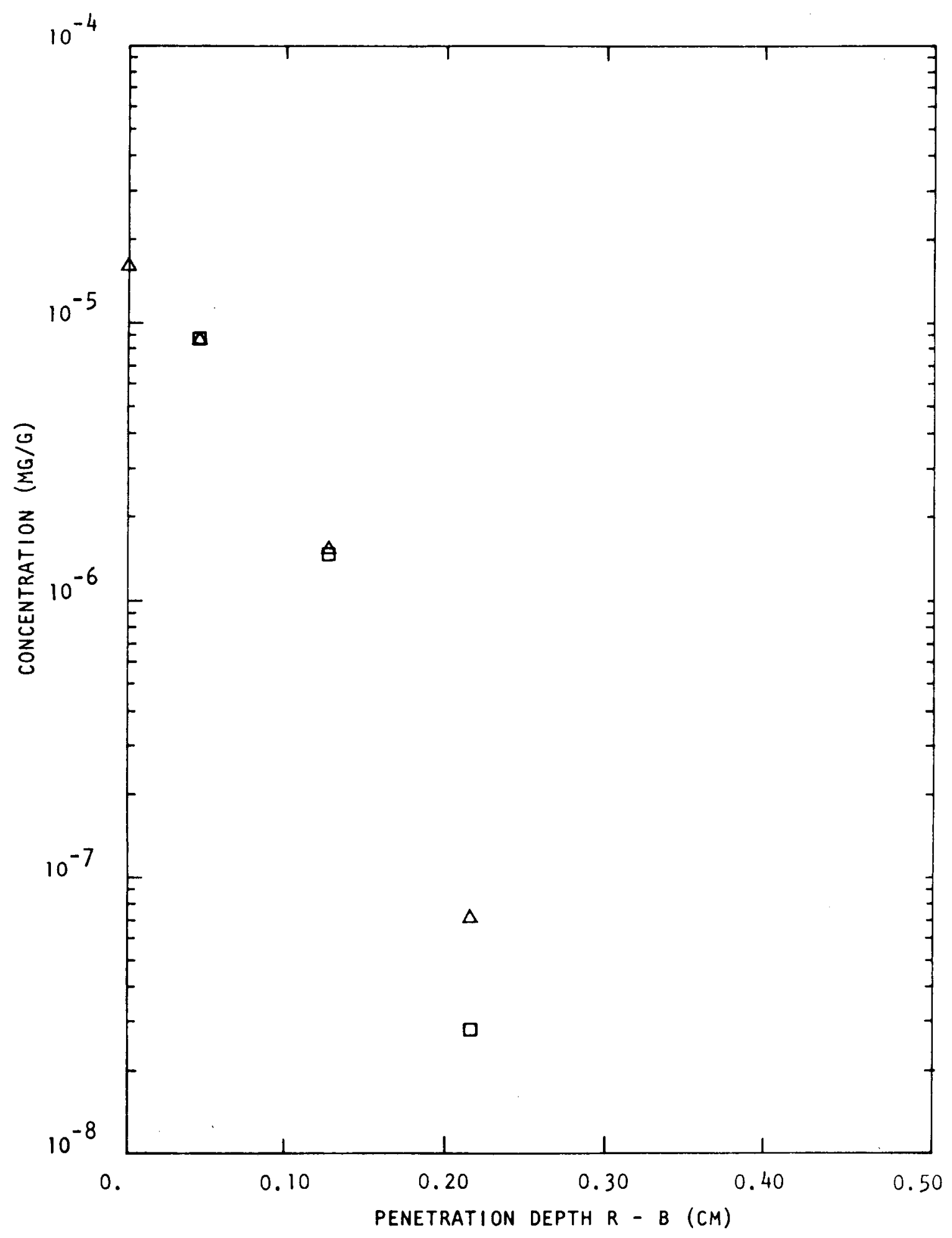

Fig. 93b. FTE-3-45 crucible wall Ba-133 


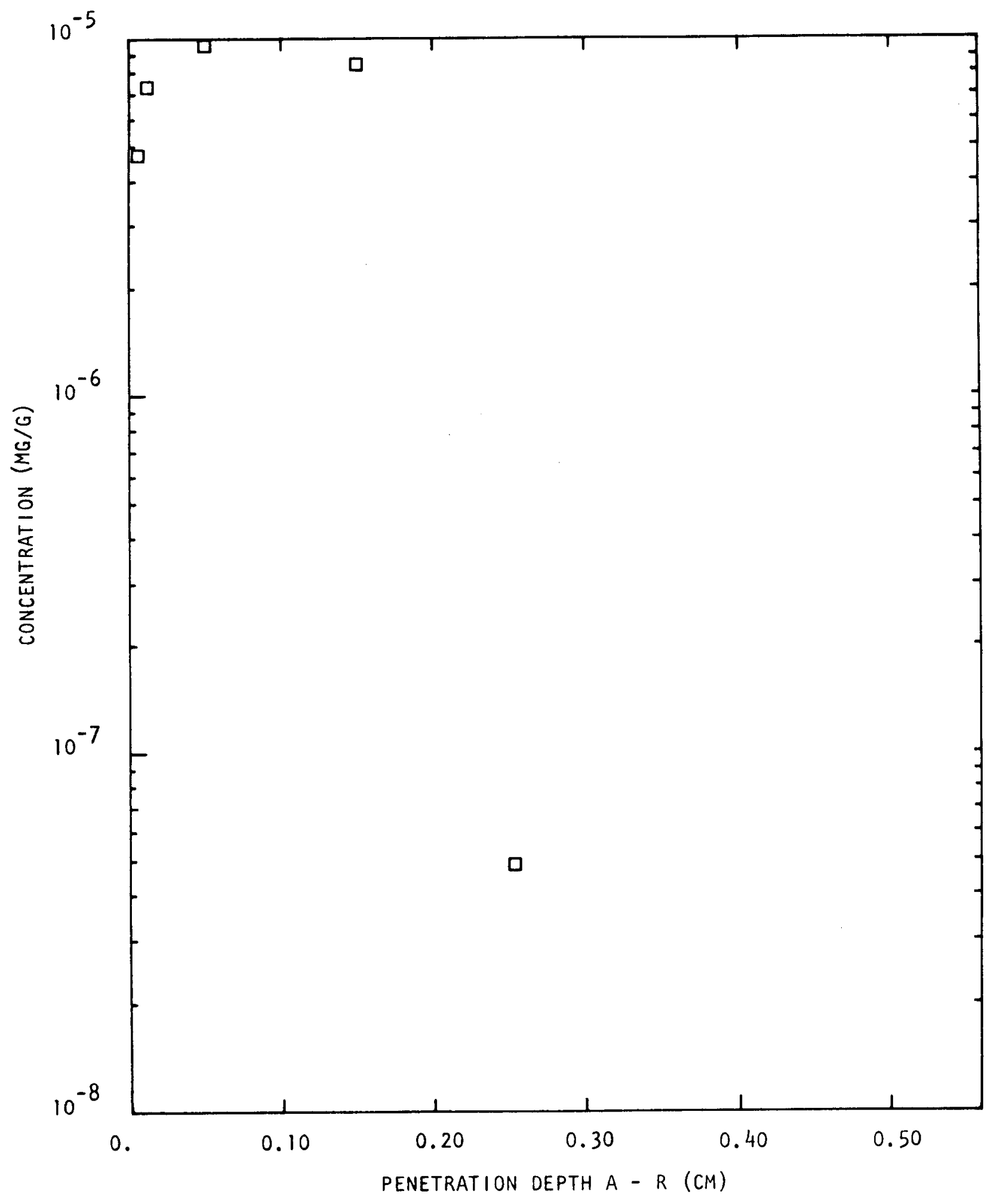

Fig. 94. FTE-3-45 center post $\mathrm{Ba}-133$ 


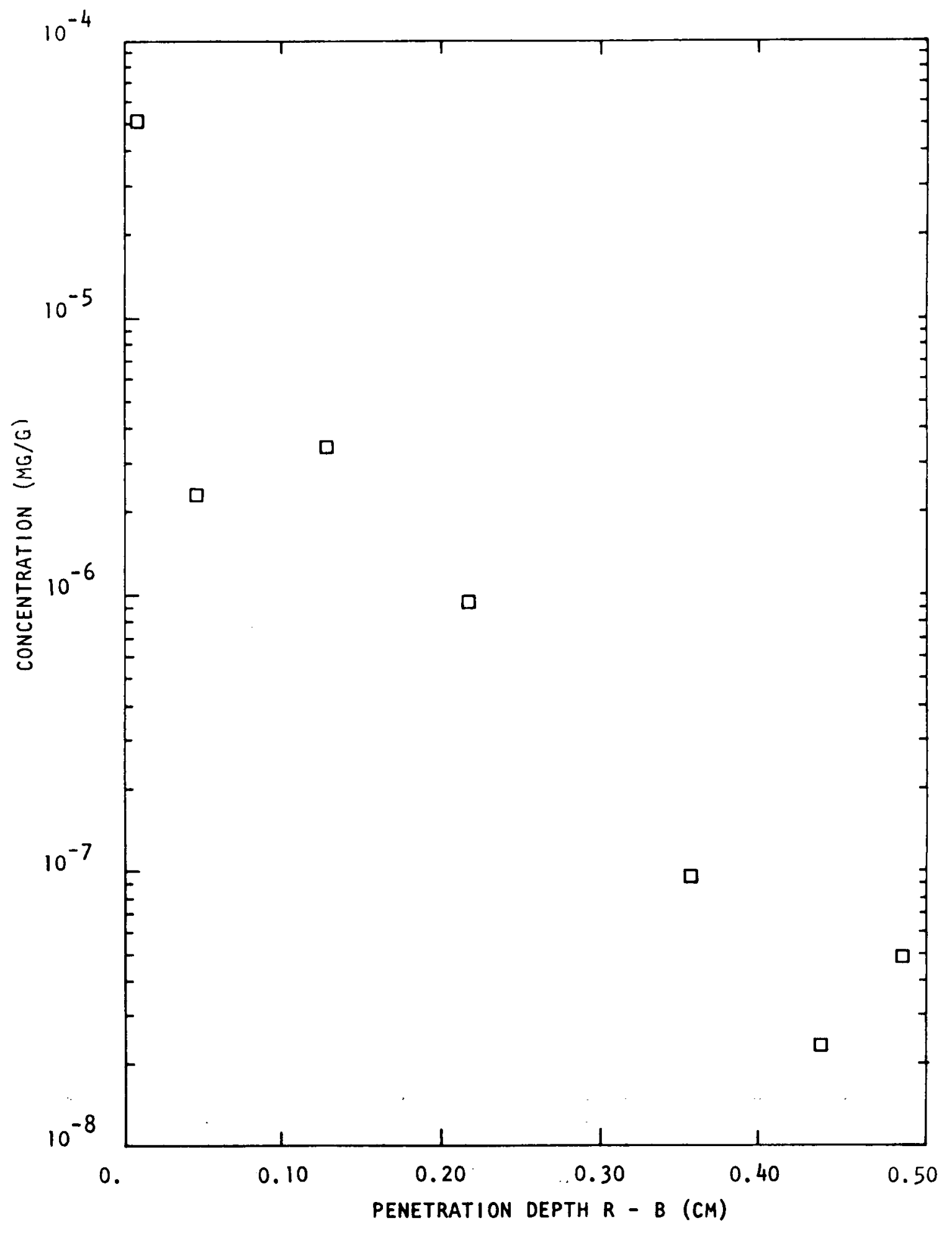

Fig. 95. FTE-3-55 crucible wa11 Ba-133 


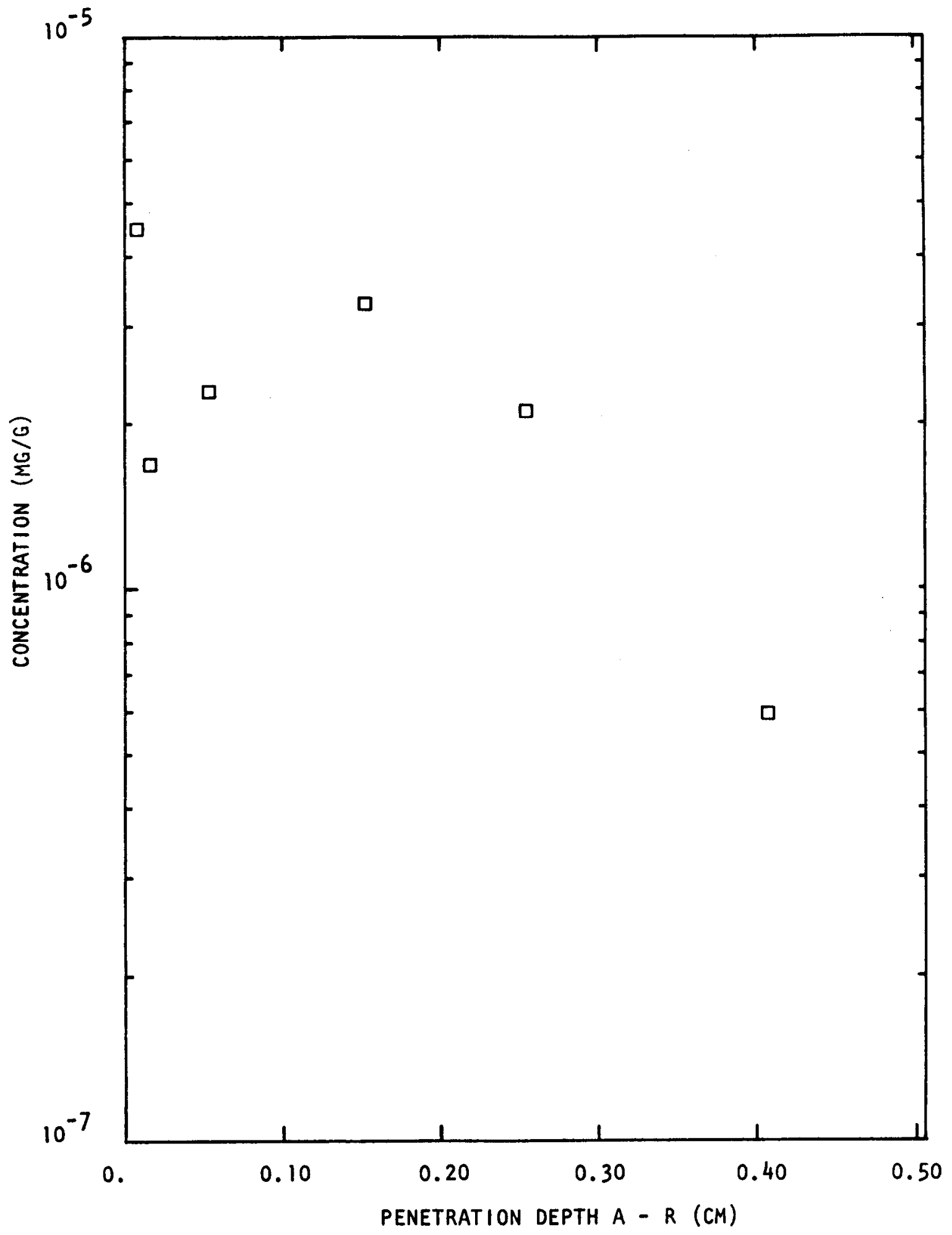

Fig. 96. FTE-3-55 center post $\mathrm{Ba}-133$ 


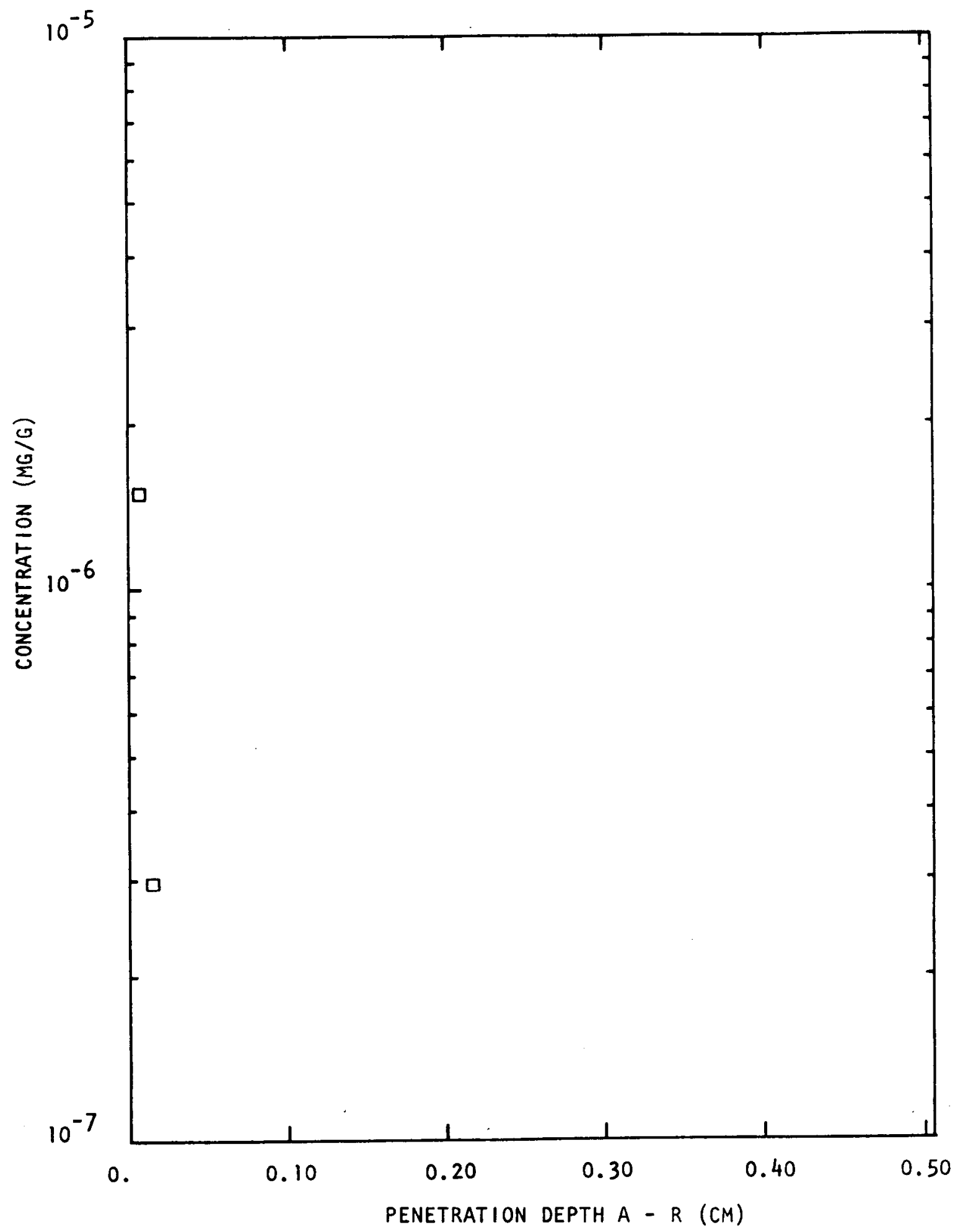

Fig. 97. FTE-3-63 center post $\mathrm{Ba}-133$ 


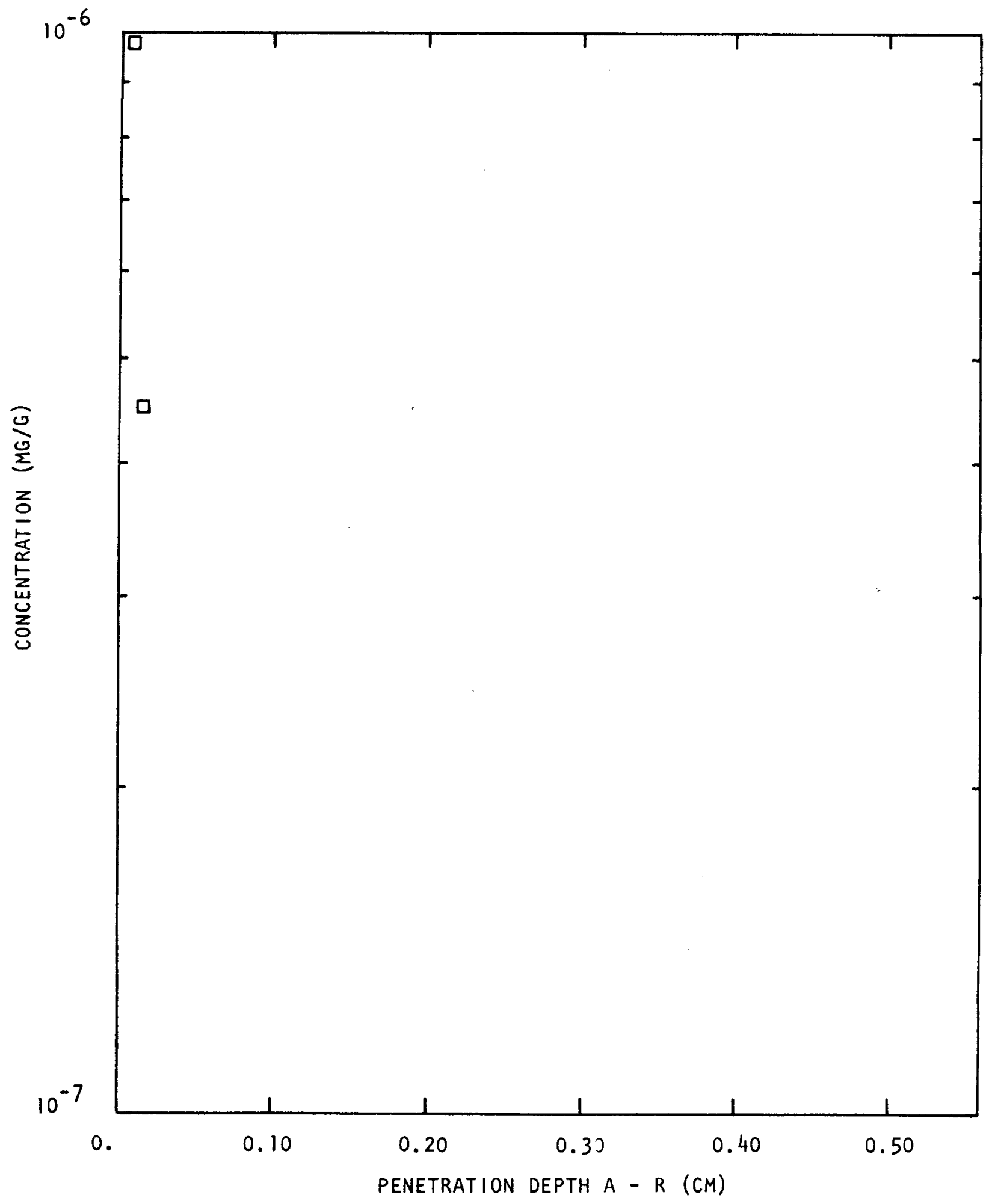

Fig. 98. FTE-3-66 center post $\mathrm{Ba}-133$ 


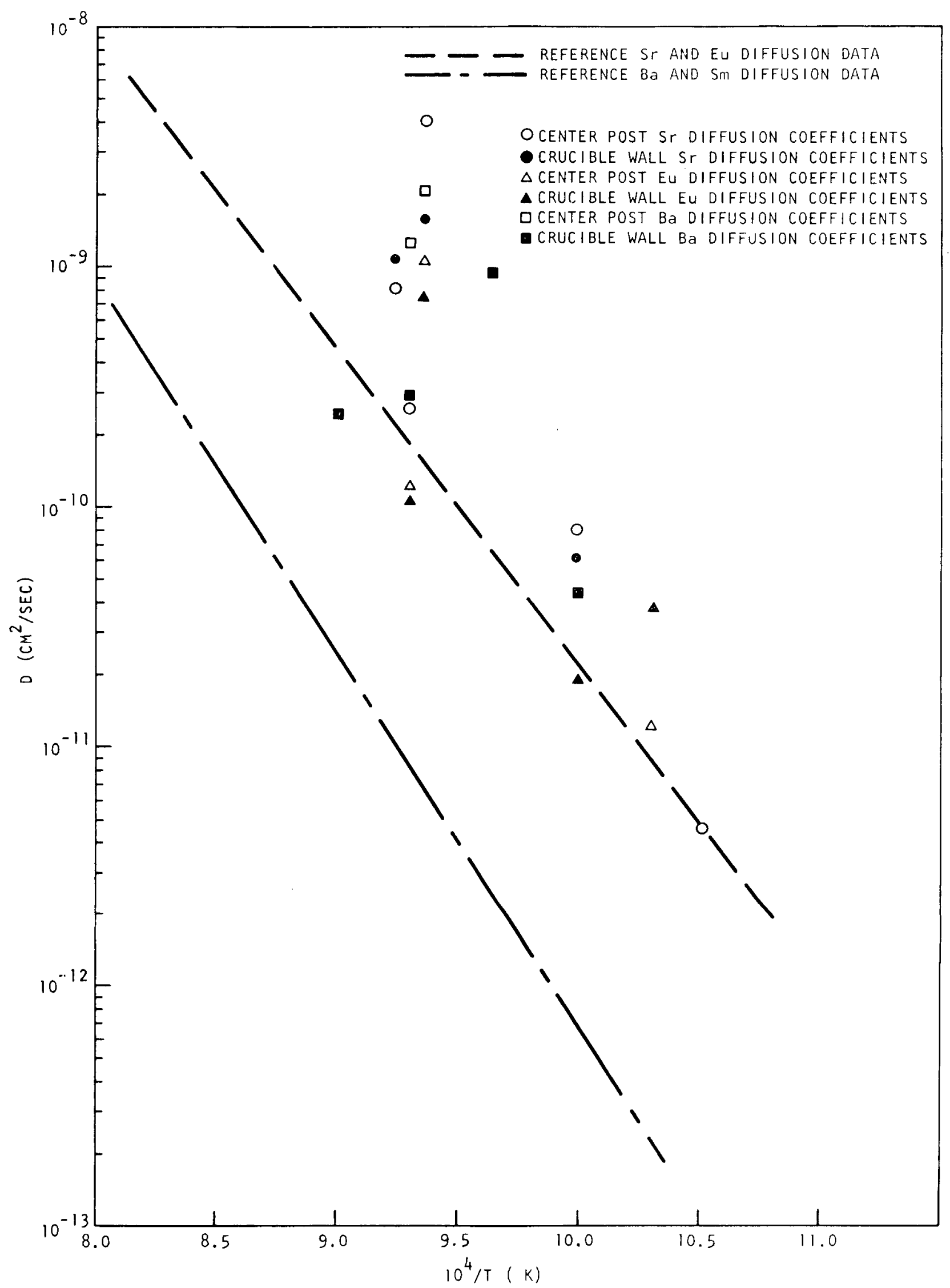

Fig. 99. Diffusion coefficients of $\mathrm{Sr}, \mathrm{Eu}$, and $\mathrm{Ba}$ from FTE-3 diffusion samples 

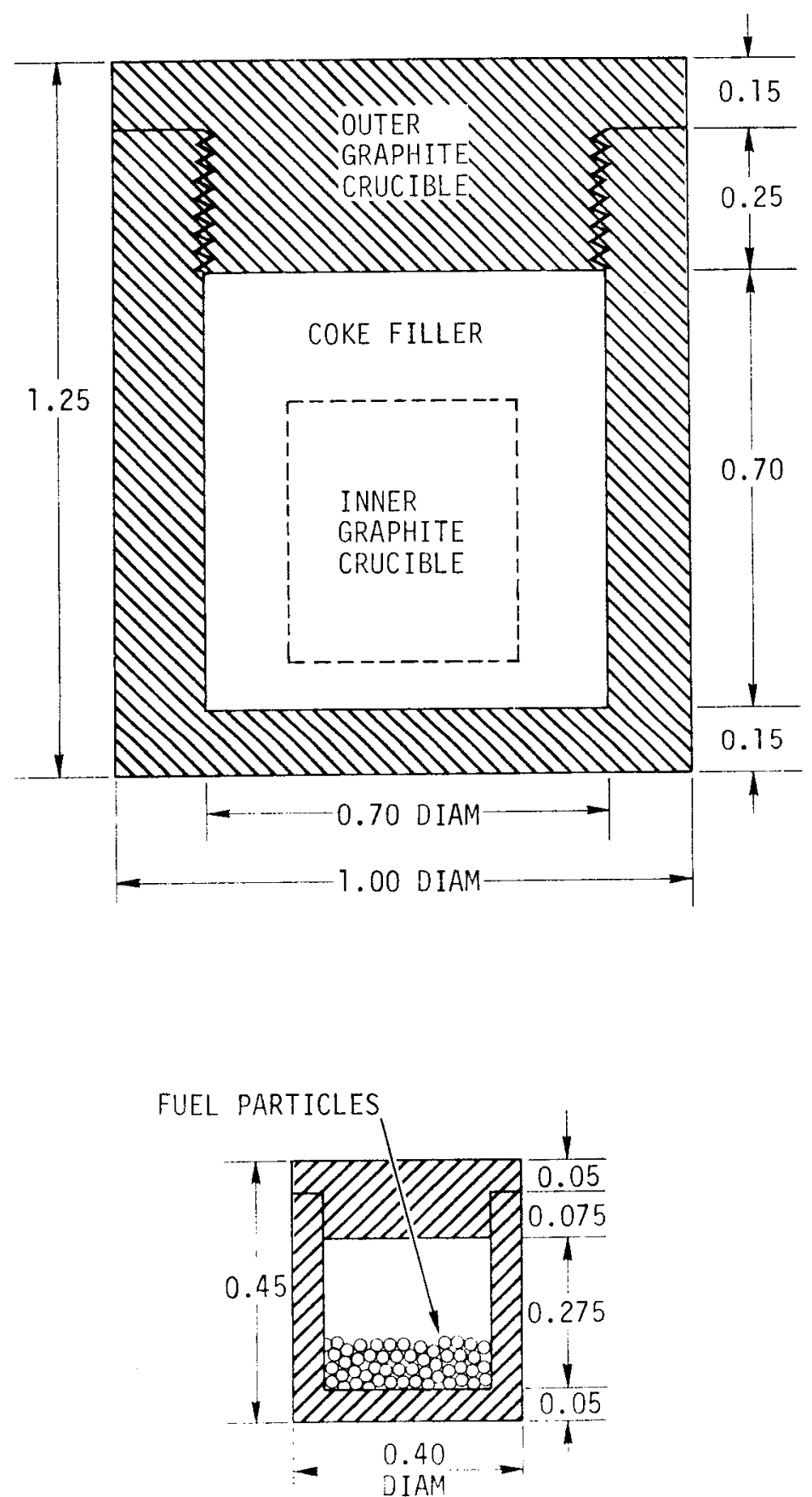

ALL DIMENSIONS IN INCHES

Fig. 100. Design of type 1 fission product release spine samples: outer crucible (graphite) above, and inner crucible below 

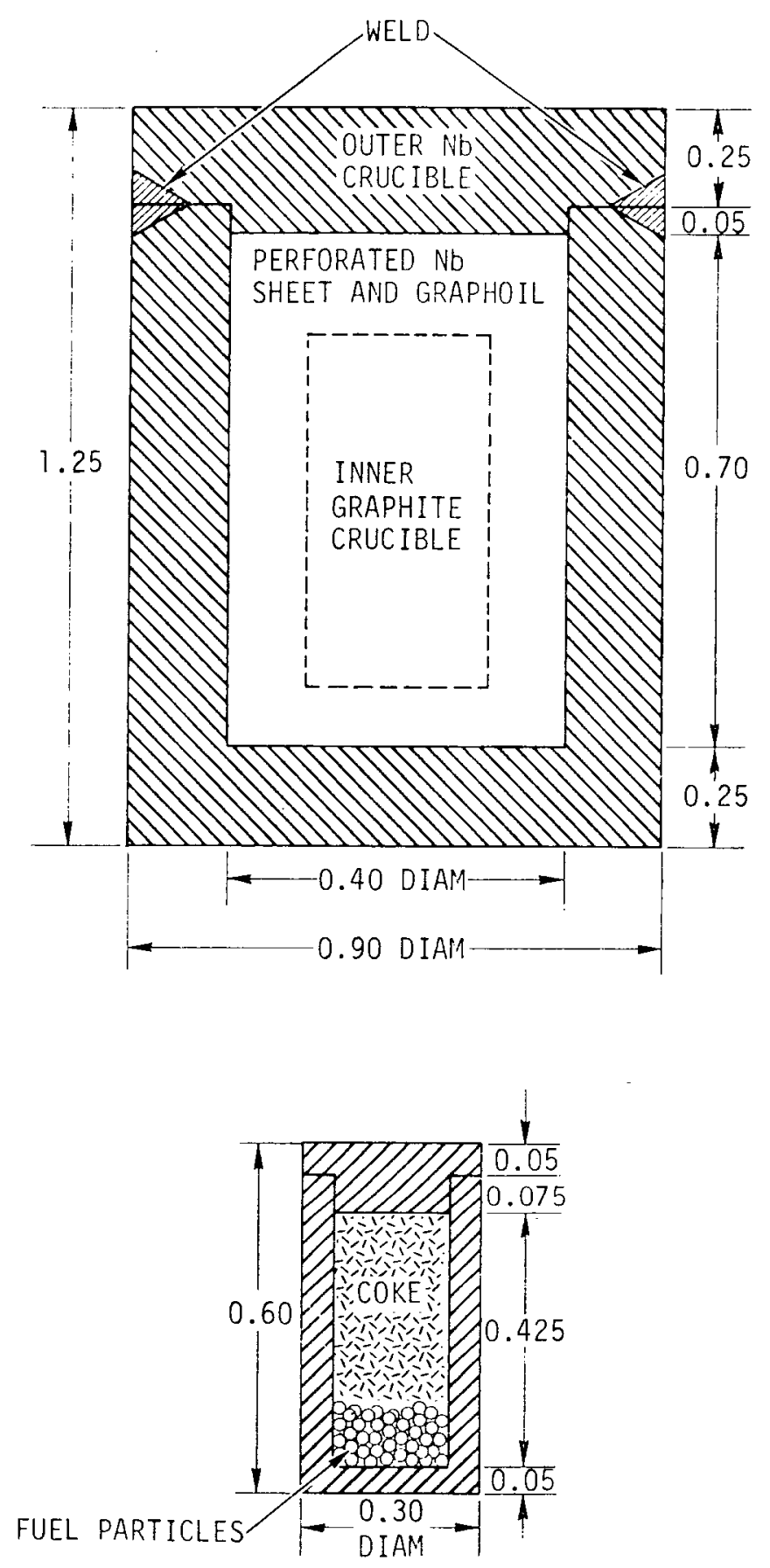

ALL DIMENSIONS IN INCHES

Fig. 101. Design of fission product release spine samples in FTE-3: top, outer crucible (niobium), and bottom, inner crucible 
APPENDIX B

TABLES 
TABLE 1

FTE-3 AVERAGE THERMOCOUPLE READINGS

\begin{tabular}{|c|c|c|c|c|c|c|c|c|}
\hline \multirow[b]{2}{*}{$\begin{array}{l}\text { Time } \\
\text { Phase }\end{array}$} & \multicolumn{2}{|c|}{ Period Covered } & \multicolumn{4}{|c|}{ Thermocouple Readings } & \multicolumn{2}{|c|}{$\begin{array}{c}\text { Thermal and } \\
\text { Physics } \\
\text { Calculations }\end{array}$} \\
\hline & $\begin{array}{c}\text { Datum } \\
\operatorname{EFPD}(a)\end{array}$ & $\begin{array}{l}\text { Datum } \\
\text { EFPD }\end{array}$ & $\begin{array}{c}\text { No. of } \\
\text { Readings }\end{array}$ & $\begin{array}{l}\text { W/Re } \\
\left({ }^{\circ} \mathrm{C}\right)\end{array}$ & $\begin{array}{l}\mathrm{C} / \mathrm{A} \\
\left({ }^{\circ} \mathrm{C}\right)\end{array}$ & $\begin{array}{l}\delta \mathrm{T}^{\prime} \\
\left({ }^{\circ} \mathrm{C}\right)\end{array}$ & $\begin{array}{l}\delta \mathrm{T}^{(\mathrm{b})} \\
\left({ }^{\circ} \mathrm{C}\right)\end{array}$ & $\begin{array}{l}\text { Power } \\
\text { Factor }\end{array}$ \\
\hline 1 & $\begin{array}{c}7 / 11 / 71 \\
0\end{array}$ & $\begin{array}{c}7 / 25 / 71 \\
12\end{array}$ & 1 & -- & $985(c)$ & -- & 140 & 0.96 \\
\hline 2 & $\begin{array}{c}7 / 28 / 71 \\
12\end{array}$ & $\begin{array}{c}8 / 31 / 71 \\
41\end{array}$ & 3 & 837 & 624 & 213 & 168 & 0.93 \\
\hline 3 & $\begin{array}{c}7 / 3 / 71 \\
41\end{array}$ & $\begin{array}{c}10 / 31 / 71 \\
90\end{array}$ & 7 & 780 & 652 & 128 & 168 & 0.93 \\
\hline 4 & $\begin{array}{c}11 / 2 / 71 \\
90\end{array}$ & $\begin{array}{c}1 / 7 / 72 \\
133\end{array}$ & 4 & 725 & 641 & 84 & 150 & 0.84 \\
\hline
\end{tabular}

(a) Equivalent ful1-power days.

(b) From Table 2.

(c) Questionable reading. 
TABLE 2

$\triangle T$ CORRECTION FOR THERMOCOUPLE READINGS AND CENTERLINE FUEL TEMPERATURE (at same axial level)

\begin{tabular}{|c|c|c|c|c|c|c|}
\hline & \multicolumn{3}{|c|}{ Power Factor $=0.95$} & \multicolumn{3}{|c|}{ Power Factor $=0.85$} \\
\hline & $\begin{aligned} \mathrm{BOL} \\
\mathrm{k}=25^{(a)}\end{aligned}$ & $\mathrm{MOL}^{(\mathrm{b})}$ & $\begin{array}{l}E O L \\
k=16\end{array}$ & $\begin{array}{l}\text { BOL } \\
k=25\end{array}$ & $\mathrm{MOL}^{(\mathrm{b})}$ & $\begin{array}{l}E O L \\
k=16\end{array}$ \\
\hline $\mathrm{W} / \mathrm{Re} \Delta \mathrm{T},{ }^{\circ} \mathrm{C}$ & 108 & 98 & 88 & 97 & 88 & 79 \\
\hline $\mathrm{C} / \mathrm{A} \Delta \mathrm{T},{ }^{\circ} \mathrm{C}$ & 248 & 266 & 283 & 222 & 238 & 253 \\
\hline$\delta \mathrm{T}(\mathrm{C} / \mathrm{A}-\mathrm{W} / \mathrm{Re}),{ }^{\circ} \mathrm{C}$ & 140 & 168 & 195 & 125 & 150 & 175 \\
\hline $\begin{array}{l}\text { Time Phase } \\
\text { (in Tables } 1 \text { and } 3 \text { ) }\end{array}$ & 1 & 2,3 & -- & -- & 4 & -- \\
\hline
\end{tabular}

(a) $\mathrm{k}=$ thermal conductivity in $\mathrm{Btu} / \mathrm{hr}-\mathrm{ft}-{ }^{\circ} \mathrm{F}$.

(b) MOL (middle of life = arithmetical average of BOL (beginning of life) and EOL (end of life), chosen because of short irradiation

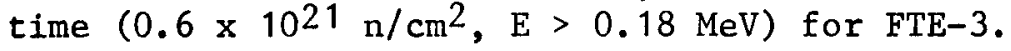


TABLE 3

FTE-3 CENTERLINE FUEL (a) TEMPERATURES ( $\left.{ }^{\circ} \mathrm{C}\right)$ FROM THERMOCOUPLE READINGS (TABLE 1 AND CORRECTION (TABLE 2)

\begin{tabular}{r|c|c|c|c|c}
\hline $\begin{array}{r}\text { Time Phase: } \\
\text { EFPD Period: }\end{array}$ & 1 & 2 & 3 & 4 & 5 \\
\hline From W/Re Readings & -- & 935 & 878 & 813 & -- \\
From C/A Readings & $1233^{(\mathrm{b})}$ & 890 & 918 & 859 & -- \\
Average & $1233^{(\mathrm{b})}$ & 913 & 898 & 836 & $911^{(\mathrm{a})}$ \\
\hline
\end{tabular}

(a) Balanced via EFPD; related to $\mathrm{T} / \mathrm{C}$ axial position, axial peak is $\sim 2^{\circ} \mathrm{C}$ higher.

(b) Questionable measurement. 
TABLE 4

FTE-3 AVERAGE NUCLIDE WEIGHTS(a) FOR FUEL RODS,

SPINE SAMPLES, AND TOTAL ELEMENT

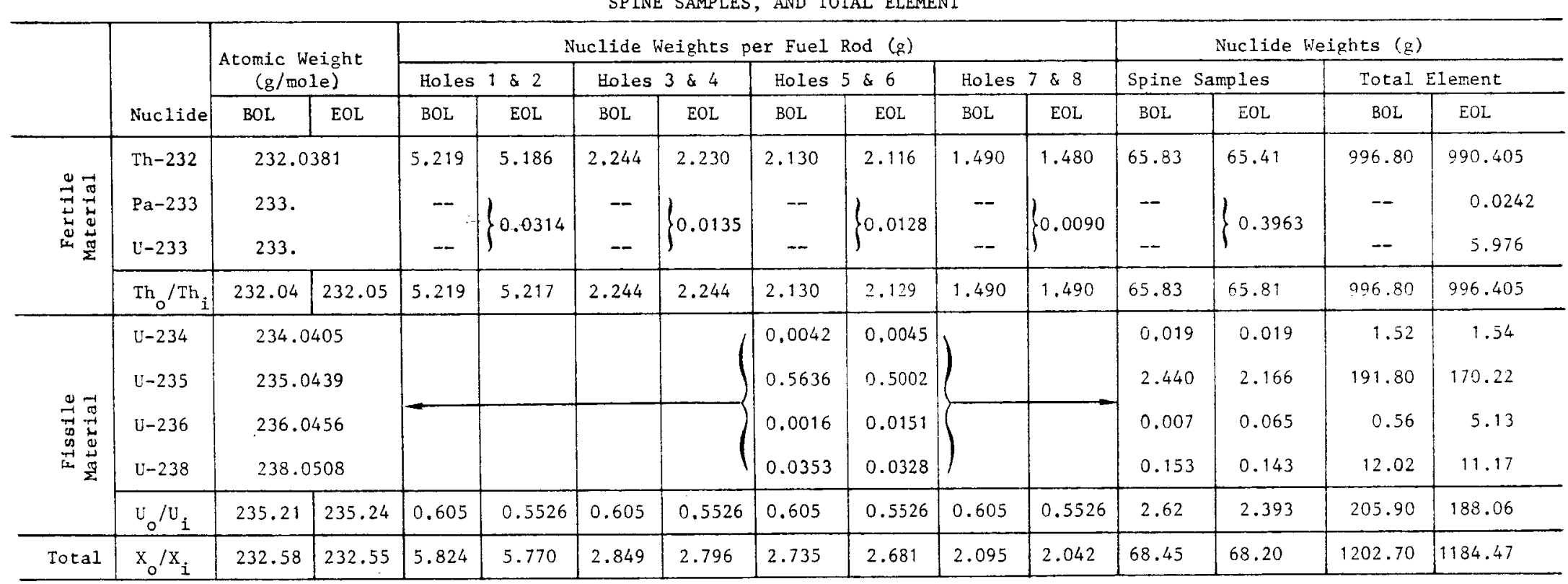

(a) $\mathrm{BOL}$ as manufactured and loaded values EOL values from physics calculations 
TABLE 5

FTE-3 AVERAGE CALCULATED BURNUP

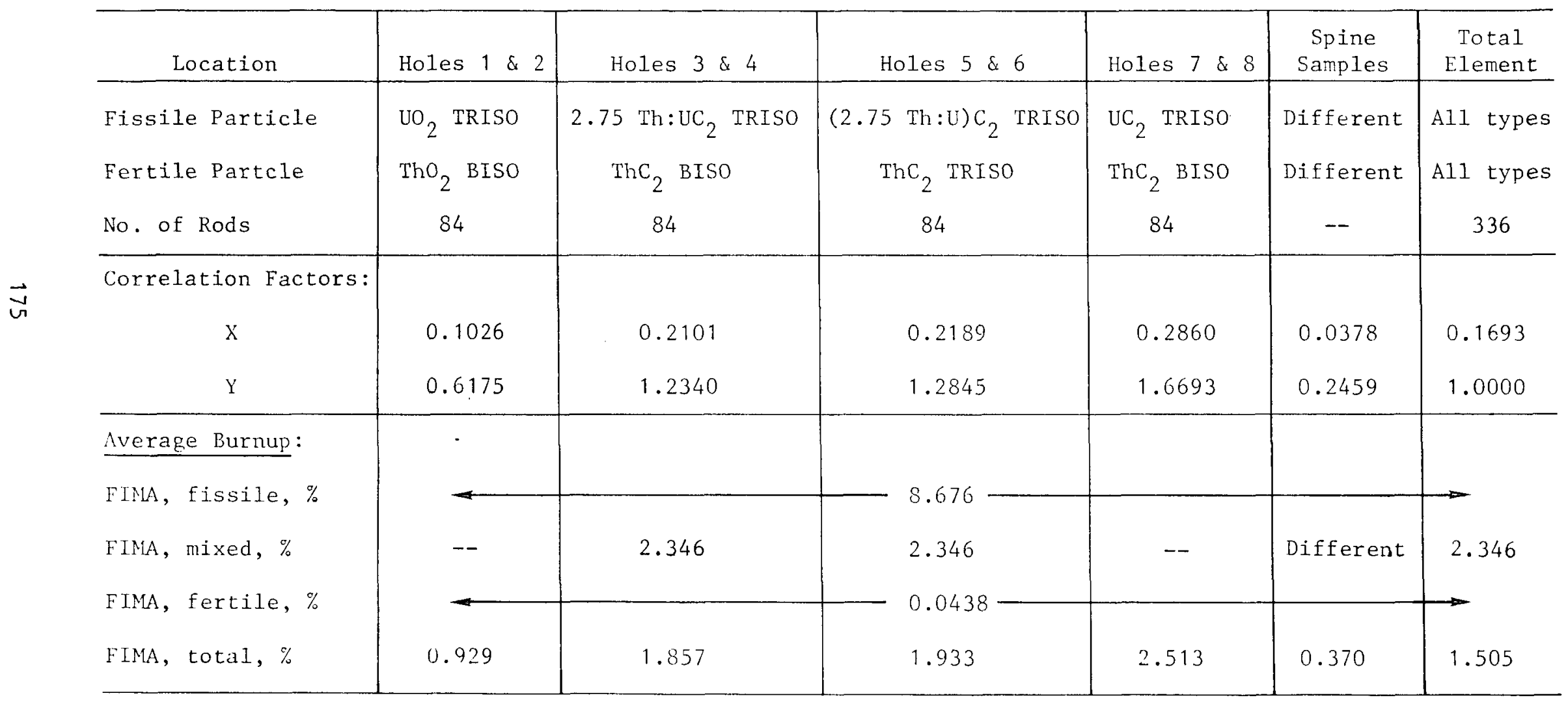


TABLE: 6

SUMMARY OF TEMPIIRATURF AND BURNUP EVALUATION FOR FIT-3

\begin{tabular}{|c|c|c|c|c|c|c|c|c|c|}
\hline & \multirow{2}{*}{$\begin{array}{l}\text { Fucl } \\
\text { Rond } \\
\text { No. }\end{array}$} & \multirow{2}{*}{$\begin{array}{c}\text { Active } \\
\text { Core } \\
\text { Height } \\
(\text { in. })\end{array}$} & \multicolumn{2}{|c|}{ Irrad. Temperaturc (a) } & \multirow{2}{*}{$\begin{array}{c}\text { Normalizer } \\
\text { Thermal } \\
\text { Fluence } \\
\end{array}$} & \multicolumn{4}{|c|}{ FTMA (Calculated) } \\
\hline & & & $\begin{array}{l}\mathrm{Ca}] \mathrm{C} \cdot \mathrm{BOL} \\
\left({ }^{\circ} \mathrm{C}+100^{\circ} \mathrm{C}\right)\end{array}$ & $\begin{array}{l}\text { Eval. Avg. } \\
\left({ }^{\circ} \mathrm{C}+100^{\circ} \mathrm{C}\right)\end{array}$ & & $\begin{array}{c}\text { Ftssile } \\
(\%)\end{array}$ & $\begin{array}{c}\text { Mixed } \\
(\%)\end{array}$ & $\begin{array}{c}\text { Fertili } \\
(\%)\end{array}$ & $\mid \begin{array}{c}\operatorname{Totan}(b) \\
(\%)\end{array}$ \\
\hline m & $\begin{array}{l}T n \\
14 \\
13 \\
12 \\
11 \\
10 \\
9 \\
8 \\
7 \\
6 \\
5 \\
4 \\
3 \\
2 \\
1\end{array}$ & $\begin{array}{l}90 \\
89 \\
87 \\
85 \\
83 \\
81 \\
79 \\
77 \\
75 \\
73 \\
71 \\
69 \\
67 \\
65 \\
63\end{array}$ & $\begin{array}{r}985 \\
988 \\
997 \\
1006 \\
1016 \\
1027 \\
1038 \\
1050 \\
1061 \\
1073 \\
1084 \\
1095 \\
1106 \\
1116 \\
1126\end{array}$ & $\begin{array}{l}786 \\
789 \\
794 \\
801 \\
808 \\
815 \\
823 \\
831 \\
839 \\
847 \\
855 \\
863 \\
870 \\
877 \\
884\end{array}$ & $\begin{array}{l}0.622 \\
0.598 \\
0.588 \\
0.608 \\
0.641 \\
0.693 \\
0.740 \\
0.787 \\
0.834 \\
0.885 \\
0.938 \\
0.994 \\
1.031 \\
1.080 \\
1.121\end{array}$ & $\begin{array}{c}-- \\
5.19 \\
5.10 \\
5.27 \\
5.56 \\
6.01 \\
6.42 \\
6.83 \\
7.24 \\
7.68 \\
8.14 \\
8.62 \\
9.00 \\
9.37 \\
9.73\end{array}$ & $\begin{array}{l}-- \\
1.40 \\
1.38 \\
1.43 \\
1.50 \\
1.63 \\
1.74 \\
1.85 \\
1.96 \\
2.08 \\
2.20 \\
2.33 \\
2.42 \\
2.53 \\
2.63\end{array}$ & $\begin{array}{l}0.026 \\
0.026 \\
0.027 \\
0.028 \\
0.030 \\
0.032 \\
0.034 \\
0.037 \\
0.039 \\
0.041 \\
0.044 \\
0.045 \\
0.047 \\
0.049\end{array}$ & $\begin{array}{l}0.0 \\
0.00 \\
0.89 \\
0.91 \\
0.97 \\
1.04 \\
1.11 \\
1.18 \\
1.86 \\
1.33 \\
1.41 \\
1.50 \\
1.56 \\
1.63 \\
1.69\end{array}$ \\
\hline $\begin{array}{l}2 \\
\ddot{g} \\
0\end{array}$ & $\begin{array}{l}14 \\
13 \\
12 \\
11 \\
10 \\
\mathrm{~T} / \mathrm{C} \text { Pos } \\
9 \\
8 \\
7 \\
6 \\
5 \\
4 \\
3 \\
2 \\
1\end{array}$ & $\begin{array}{l}58 \\
56 \\
54 \\
52 \\
50 \\
49.5 \\
48 \\
46 \\
44 \\
42 \\
40 \\
38 \\
36 \\
34 \\
32\end{array}$ & $\begin{array}{l}1146 \\
1153 \\
1158 \\
1162 \\
1166 \\
1166 \\
1168 \\
1168 \\
1167 \\
1164 \\
1160 \\
1154 \\
1147 \\
1137 \\
1125\end{array}$ & $\begin{array}{l}898 \\
902 \\
906 \\
909 \\
911 \\
911 \\
912 \\
913 \\
912 \\
910 \\
907 \\
903 \\
898 \\
891 \\
883\end{array}$ & $\begin{array}{l}1.206 \\
1.230 \\
1.253 \\
1.270 \\
1.285 \\
1.287 \\
1.293 \\
1.298 \\
1.298 \\
1.298 \\
1.298 \\
1.291 \\
1.285 \\
1.281 \\
1.275\end{array}$ & $\begin{array}{c}10.46 \\
10.67 \\
10.87 \\
11.01 \\
11.15 \\
-- \\
11.21 \\
11.27 \\
11.27 \\
11.27 \\
11.27 \\
11.20 \\
11.15 \\
11.11 \\
11.06\end{array}$ & $\begin{array}{l}2.83 \\
2.89 \\
2.94 \\
2.98 \\
3.01 \\
-- \\
3.03 \\
3.05 \\
3.05 \\
3.05 \\
3.05 \\
3.05 \\
3.01 \\
3.00 \\
2.99\end{array}$ & $\begin{array}{l}0.053 \\
0.054 \\
0.055 \\
0.056 \\
0.056 \\
-- \\
0.057 \\
0.057 \\
0.057 \\
0.057 \\
0.057 \\
0.057 \\
0.056 \\
0.056 \\
0.056\end{array}$ & $\begin{array}{l}1.82 \\
1.85 \\
1.89 \\
1.91 \\
1.93 \\
-- \\
1.95 \\
1.95 \\
1.95 \\
1.95 \\
1.95 \\
1.94 \\
1.93 \\
1.93 \\
1.92\end{array}$ \\
\hline - & $\begin{array}{r}14 \\
13 \\
12 \\
11 \\
10 \\
9 \\
8 \\
7 \\
6 \\
5 \\
4 \\
3 \\
2 \\
1 \\
\text { Bottom } \\
\end{array}$ & $\begin{array}{r}27 \\
25 \\
23 \\
21 \\
19 \\
17 \\
15 \\
13 \\
11 \\
9 \\
7 \\
5 \\
3 \\
1 \\
0 \\
\end{array}$ & $\begin{array}{r}1087 \\
1067 \\
1046 \\
1022 \\
995 \\
966 \\
934 \\
898 \\
860 \\
819 \\
774 \\
726 \\
676 \\
620 \\
592 \\
\end{array}$ & $\begin{array}{l}857 \\
843 \\
828 \\
812 \\
793 \\
773 \\
751 \\
727 \\
700 \\
672 \\
641 \\
608 \\
573 \\
535 \\
515 \\
\end{array}$ & $\begin{array}{l}1.245 \\
1.226 \\
1.200 \\
1.173 \\
1.129 \\
1.053 \\
0.974 \\
0.879 \\
0.811 \\
0.700 \\
0.641 \\
0.572 \\
0.529 \\
0.462 \\
0.439 \\
\end{array}$ & $\begin{array}{r}10.80 \\
10.63 \\
10.41 \\
10.17 \\
9.80 \\
9.13 \\
8.45 \\
7.63 \\
7.03 \\
6.08 \\
5.56 \\
4.97 \\
4.59 \\
4.01 \\
--\end{array}$ & $\begin{array}{l}2.92 \\
2.88 \\
2.82 \\
2.75 \\
2.65 \\
2.47 \\
2.28 \\
2.06 \\
1.90 \\
1.64 \\
1.50 \\
1.34 \\
1.24 \\
1.08 \\
-- \\
\end{array}$ & $\begin{array}{l}0.055 \\
0.054 \\
0.053 \\
0.051 \\
0.049 \\
0.046 \\
0.043 \\
0.039 \\
0.036 \\
0.031 \\
0.028 \\
0.025 \\
0.023 \\
0.020 \\
-- \\
\end{array}$ & $\begin{array}{l}1.87 \\
1.84 \\
1.81 \\
1.76 \\
1.70 \\
1.58 \\
1.47 \\
1.32 \\
1.22 \\
1.05 \\
0.97 \\
0.86 \\
0.80 \\
0.70 \\
-- \\
\end{array}$ \\
\hline & & & & & $\begin{array}{l}0.5083 \times 10^{21} \mathrm{~cm}^{-2} \\
\mathrm{E}<2.38 \mathrm{eV}^{(\mathrm{c})}\end{array}$ & $8.676 \%(c)$ & $2.346 \%(c)$ & $0.438 \%(c)$ & $1.505 \%(c)$ \\
\hline
\end{tabular}


TABLE 7

FTE-3 FUEL STACK DIMENSIONAL CHANGES

\begin{tabular}{l|c|c|c}
\hline & $\begin{array}{c}\text { FTE-3/1 } \\
\text { Bottom }\end{array}$ & $\begin{array}{c}\text { FTE-3/2 } \\
\text { Center }\end{array}$ & $\begin{array}{c}\text { FTE-3/3 } \\
\text { Top }\end{array}$ \\
\hline $\begin{array}{l}\text { Average fuel stack length } \\
\text { (preirradiation), in. }\end{array}$ & 27.330 & 27.300 & 27.334 \\
$\begin{array}{l}\text { Gamma scan ( } \Delta \mathrm{L} / \mathrm{L}), \% \\
\begin{array}{l}\text { Plenum measurement (a) } \\
(\Delta \mathrm{L} / \mathrm{L}), \% \text { (Table 11) }\end{array}\end{array}$ & -0.77 & $(-0.26)$ & -0.71 \\
$\begin{array}{l}\text { Axial fuel rod measurement } \\
(\Delta \mathrm{L} / \mathrm{L}), \% \text { (a) }\end{array}$ & -0.59 & -0.82 & -0.69 \\
$\begin{array}{l}\text { Radial fuel rod measurement } \\
(\Delta \mathrm{D} / \mathrm{D}), \% \text { (Table 21) }\end{array}$ & -0.90 & -1.46 & -1.02 \\
\hline
\end{tabular}

(a) Averaged over all eight fuel zones.

(b) Suspected evaluation error. 
TABLE 8
FTE-3 THERMOCOUPLE RESISTANCE MEASUREMENTS

\begin{tabular}{|c|c|c|c|c|c|c|c|c|c|c|}
\hline & \multicolumn{3}{|c|}{$\begin{array}{l}\text { + to Ground } \\
\text { Circuit }(\Omega)\end{array}$} & \multicolumn{3}{|c|}{$\begin{array}{l}\text { - to Ground } \\
\text { Circuit }(\Omega)\end{array}$} & \multicolumn{3}{|c|}{ Loop $(\Omega)$} & \multirow[b]{2}{*}{ Remarks } \\
\hline & $\begin{array}{l}\text { Pre- } \\
\text { Irrad. }\end{array}$ & $\begin{array}{l}\text { Post- } \\
\text { Irrad. }\end{array}$ & $\Delta \Omega$ & $\begin{array}{l}\text { Pre- } \\
\text { Irrad. }\end{array}$ & $\begin{array}{l}\text { Post- } \\
\text { Irrad. }\end{array}$ & $\Delta \Omega$ & $\begin{array}{l}\text { Pre- } \\
\text { Irrad. }\end{array}$ & $\begin{array}{l}\text { Post- } \\
\text { Irrad. }\end{array}$ & $\Delta \Omega$ & \\
\hline $\begin{array}{l}\text { Thermocouple A } \\
\text { (ARI S/N 22163) } \\
\text { W-3\%Re/W-25\%Re }\end{array}$ & 4.3 & 4.5 & +0.2 & 11.8 & 12.0 & +0.2 & 15.3 & 15.0 & -0.3 & Satisfactory \\
\hline $\begin{array}{l}\text { Thermocouple B } \\
\text { (ARI S/N 22170) } \\
\text { C/A }\end{array}$ & 34.1 & 37.0 & +2.9 & 15.8 & 15.0 & -0.8 & 48.0 & 53.0 & +5.0 & Satisfactory \\
\hline
\end{tabular}

(a) Accuracy $\pm 2 \Omega$. 
TABLE 9

DISTANCE d FROM TOP OF SPINE TO EDGE OF HOLE ${ }^{(a)}$ IN FTE-3

\begin{tabular}{c|c|c|c|c|c|c}
\hline $\begin{array}{l}\text { Body } \\
\text { No. }\end{array}$ & $\begin{array}{c}\text { Spine Stack } \\
\text { Length (in.) }\end{array}$ & $\begin{array}{c}\mathrm{d}_{1} \\
\text { Preirrad. } \\
\text { (in.) }\end{array}$ & $\begin{array}{c}\mathrm{d}_{2} \\
\text { Postirrad. } \\
\text { (in.) }\end{array}$ & $\begin{array}{c}\Delta \mathrm{d} \\
\text { (in.) }\end{array}$ & $\begin{array}{c}\Delta G(\mathrm{~b}) \\
\text { (in.) }\end{array}$ & $\begin{array}{c}\frac{-\Delta \mathrm{d}+\Delta \mathrm{G}}{\mathrm{L}} \\
(\%)\end{array}$ \\
\hline 1 & 28.58 & 2.027 & 2.000 & -0.027 & -0.008 & $+0.07 \pm 0.05$ \\
2 & 28.49 & 2.052 & 2.125 & +0.073 & -0.026 & $-0.35 \pm 0.05$ \\
3 & 28.56 & 2.136 & 2.188 & +0.052 & -0.018 & $-0.24 \pm 0.05$ \\
\hline
\end{tabular}

(a) Accuracy \pm 0.001 in. Ref. Drawings 11504, 11505, 11506 .

(b) $\Delta G=$ length change of graphite fuel body (accuracy \pm 0.001 in.), from Tables 13, 14, and 15 . 
TABLE 10

FTE-3 SPINE SAMPLES

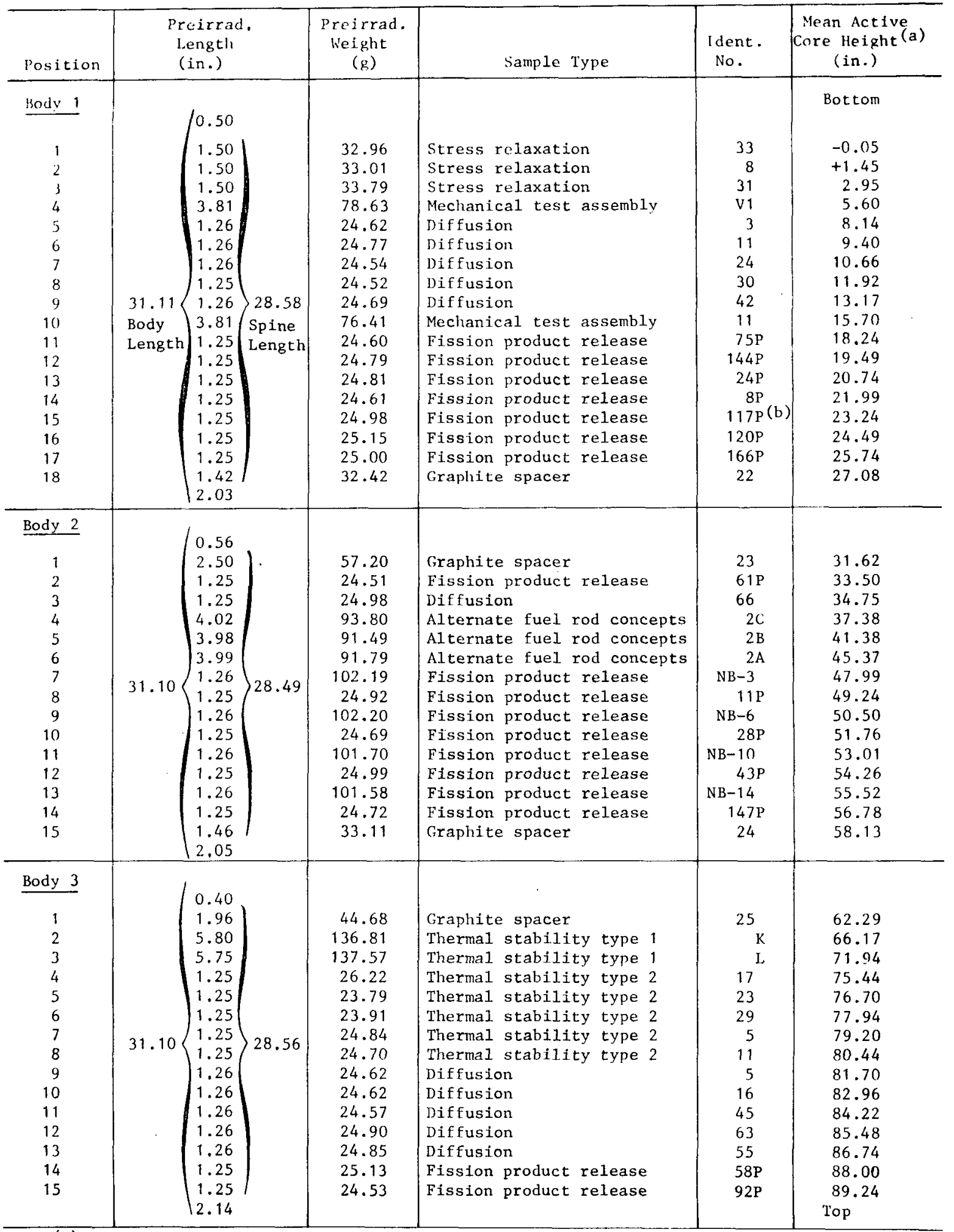

(a) Body 1 bottom line, 1.30 in, under active core height

(b) Postirradiation number $=107 \mathrm{P}$ 
TABLE 11

FTE-3 FUEL STACK MEASUREMENTS

\begin{tabular}{|c|c|c|c|c|c|c|c|}
\hline \multirow{2}{*}{$\begin{array}{l}\text { Hole } \\
\text { Number }\end{array}$} & \multirow{2}{*}{$\begin{array}{c}\text { Preirrad. Stack } \\
\text { Length, L(a) } \\
\text { (Accuracy }+0.03 /-0.01)\end{array}$} & \multirow{2}{*}{$\begin{array}{l}\Delta \mathrm{L} / \mathrm{L} \\
(\%)\end{array}$} & \multicolumn{2}{|c|}{ Plenum, $p(i n .)^{(b)}$} & \multirow{2}{*}{$\stackrel{\Delta p}{(\text { in. ) }}$} & \multirow{2}{*}{\multicolumn{2}{|c|}{ 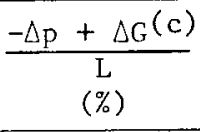 }} \\
\hline & & & Preirrad. & Postirrad. & & & \\
\hline \multicolumn{8}{|l|}{ Body 1} \\
\hline 1 & 27.387 & -101 & 2.403 & 2.672 & +0.269 & -1.01 & \\
\hline 2 & 27.391 & & 2.399 & -- & -- & -- & \\
\hline 3 & 27.317 & -0.45 & 2.473 & 2.578 & +0.105 & -0.41 & \\
\hline 4 & 27.304 & -0.43 & 2.486 & 2.609 & +0.123 & -0.48 & \\
\hline 5 & 27.310 & -0.36 & 2.480 & 2.531 & +0.051 & -0.22 & \\
\hline 6 & 27.341 & -0.36 & 2.449 & 2.578 & +0.129 & -0.50 & \\
\hline 7 & 27.284 & $-0 \quad 54$ & 2.506 & 2.641 & +0.135 & -0.52 & \\
\hline 8 & 27.308 & -0.54 & 2.482 & 2.625 & +0.143 & -0.55 & \\
\hline FTE-3/1 & $27.330 \mathrm{avg}$ & & $2.460 \mathrm{avg}$ & & & -0.59 & $a v g$ \\
\hline \multicolumn{8}{|l|}{ Body 2} \\
\hline 1 & 27.367 & & 2.473 & 2.688 & +0.215 & -0.88 & \\
\hline 2 & 27.369 & & 2.421 & 2.734 & +0.313 & -1.28 & \\
\hline 3 & 27.281 & -0.78 & 2.509 & 2.703 & +0.194 & -0.80 & \\
\hline 4 & 27.284 & -0.78 & 2.506 & 2.688 & +0.182 & -0.76 & \\
\hline 5 & 27.277 & -0.62 & 2.513 & 2.656 & +0.143 & -0.62 & \\
\hline 6 & 27.292 & -0.62 & 2.498 & 2.641 & +0.143 & -0.62 & \\
\hline 7 & 27.292 & -0.81 & 2.498 & 2.688 & +0.190 & -0.79 & \\
\hline 8 & 27.287 & -0.01 & 2.503 & 2.703 & +0.200 & -0.82 & \\
\hline $\mathrm{FTE}-3 / 2$ & $27.300 \mathrm{avg}$ & & $2.490 \mathrm{avg}$ & & & -0.82 & avg \\
\hline \multicolumn{8}{|l|}{ Body 3} \\
\hline 1 & 27.425 & & 2.365 & 2.641 & +0.276 & -1.08 & \\
\hline 2 & 27.422 & -1.06 & 2.368 & 2.634 & +0.266 & -1.04 & \\
\hline 3 & 27.305 & -0.52 & 2.485 & 2.578 & +0.093 & -0.40 & \\
\hline 4 & 27.305 & -0 & 2.485 & 2.641 & +0.156 & -0.64 & \\
\hline 5 & 27.326 & -0.69 & 2.464 & 2.625 & +0.161 & -0.65 & \\
\hline 6 & 27.326 & & 2.464 & 2.634 & +0.170 & -0.72 & \\
\hline 7 & 27.277 & & 2.513 & 2.609 & +0.096 & -0.42 & \\
\hline 8 & 27.285 & -0.49 & $\underline{2.505}$ & 2.641 & +0.136 & -0.56 & \\
\hline FTE-3/3 & 27.334 avg & & $2.456 \mathrm{avg}$ & & & -0.69 & avg \\
\hline
\end{tabular}

${ }^{(a)}$ Calculated L via nominal depth $=29.79+0.03 /-0.01$ in. minus plenum p. Nominal stack length $=27.16+0.25 /-0.16$ in.

(b) Plenum $\mathrm{p}=$ distance from top of fuel rod to edge of hole, accuracy \pm 0.001 in.

(c) $\Delta G=$ length change of graphite fuel body (accuracy \pm 0.001 in.) from Tables 13,14 , and 15 
TABLE 12

FTE-3 SLEEVE MEASUREMENTS

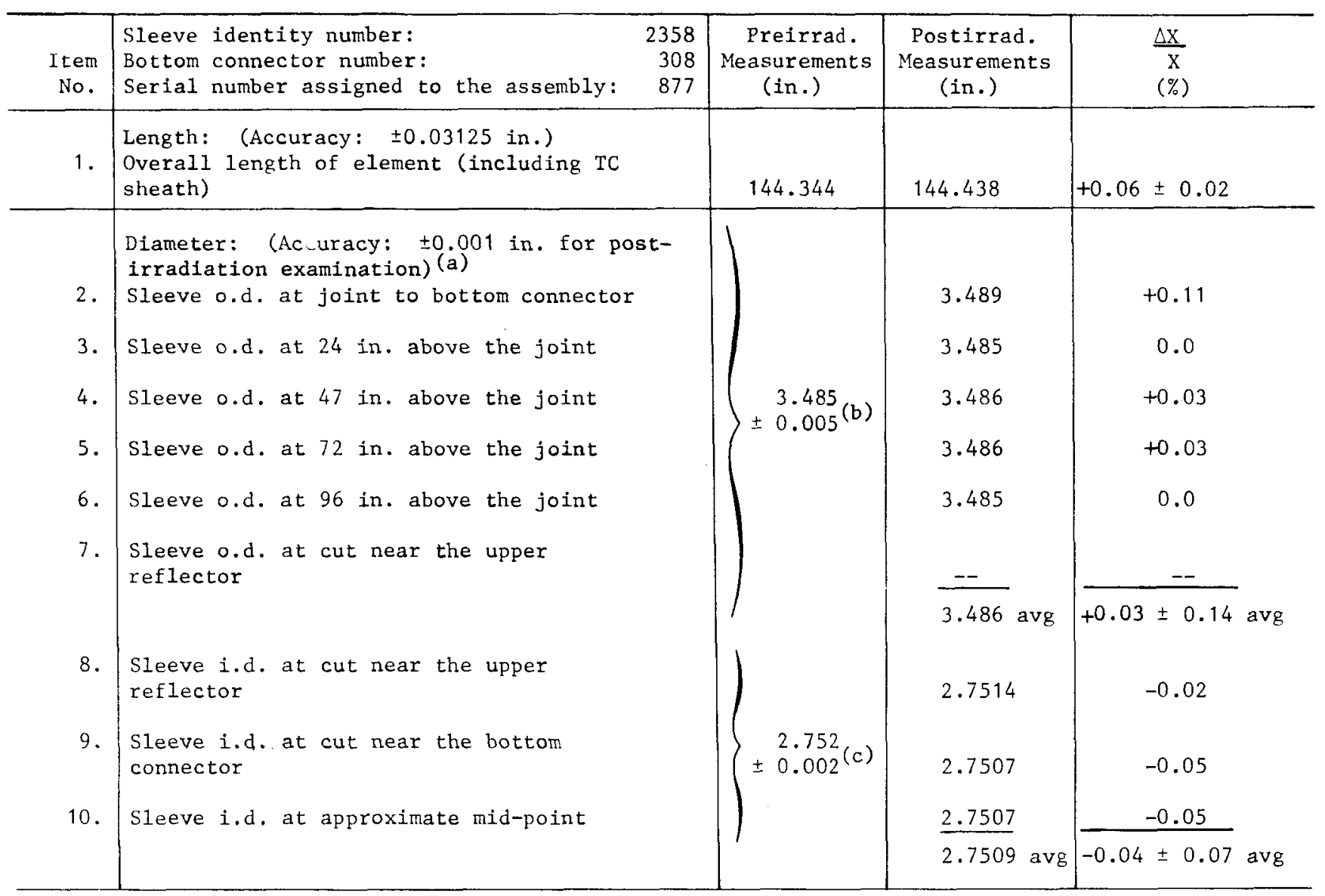

(a) Preirradiation measurements of diameters not available

(b) Sleeve o.d. per drawing 11666 is $3.485 \pm 0.005$ in.

(c) Sleeve i.d. per drawing 11666 is $2.752 \pm 0.002 \mathrm{in}$.

Note: The sleeves were examined for quality assurance at the source of supply and found to meet requirements. There is no record of the actual dimensions. 
TABLE 13

FTE-3 FUFL BODY DATA (a)

Position in element (Bottom) 1

Fuel body identification no. 32

Graphite log identification no. 2513

\begin{tabular}{|c|c|c|c|c|}
\hline $\begin{array}{l}\text { Dimension } \\
\text { Description }\end{array}$ & $\begin{array}{c}\text { Preirrad. } \\
\mathrm{X}\end{array}$ & $\begin{array}{l}\text { Postirrad. } \\
\dot{X}\end{array}$ & $\Delta \mathrm{X}$ & $\begin{array}{c}\frac{\Delta X}{X} \\
(\%)\end{array}$ \\
\hline $\begin{array}{l}\text { Weight of Loaded Body, } g \\
\text { (Accuracy: } \pm 15 \mathrm{~g} \text { ) }\end{array}$ & 4890 & 4900 & 10 & $+0.20 \pm 0.31$ \\
\hline $\begin{array}{l}\text { Length of Body, in. } \\
\text { (Dimension A) } \\
\text { (Accuracy: } \pm 0.001 \text { in.) }\end{array}$ & 31.108 & 31.100 & -0.008 & $-0.03 \pm 0.003$ \\
\hline $\begin{array}{l}\text { Outside Diameter, in. } \\
\text { (Dimension C) } \\
\text { (Accuracy: } \pm 0.001 \mathrm{in.} \text { ) }\end{array}$ & & & & \\
\hline Top $\left\{\begin{array}{l}\text { Across Holes } 1 \text { and } 5 \\
\text { Across Holes } 3 \text { and } 7 \\
\text { Average }\end{array}\right.$ & $\begin{array}{l}2.740 \\
2.740\end{array}$ & $\begin{array}{l}2.740 \\
2.739\end{array}$ & $\begin{array}{l}0 \\
-0.001\end{array}$ & $\frac{0}{-0.04}$ \\
\hline Center $\left\{\begin{array}{l}\text { Across Holes } 1 \text { and } 5 \\
\text { Across Holes } 3 \text { and } 7 \\
\text { Average }\end{array}\right.$ & $\begin{array}{l}2.740 \\
2.740\end{array}$ & $\begin{array}{l}2.740 \\
2.740\end{array}$ & $\begin{array}{l}0 \\
0\end{array}$ & $\begin{array}{c}0 \\
0 \\
0 \pm 0.04\end{array}$ \\
\hline Bottom $\left\{\begin{array}{l}\text { Across Holes } 1 \text { and } 5 \\
\text { Across Holes } 3 \text { and } 7 \\
\text { Average }\end{array}\right.$ & $\begin{array}{l}2.739 \\
2.739\end{array}$ & $\begin{array}{l}2.738 \\
2.738\end{array}$ & $\begin{array}{l}-0.001 \\
-0.001\end{array}$ & $\begin{array}{c}-0.04 \\
-0.04 \\
-0.04 \pm 0.04\end{array}$ \\
\hline Sum average & 2.7397 & 2.7392 & -0.0005 & $-0.02 \pm 0.04$ \\
\hline $\begin{array}{l}\text { Inside Diameter, in. } \\
\text { (Dimension D) } \\
\text { (Accuracy: } \pm 0.001 \text { in.) } \\
\text { Top } \\
\text { Bottom }\end{array}$ & $\begin{array}{l}1.102 \\
1.102 \\
\end{array}$ & 1.1011 & -0.0009 & $-0.08 \pm 0.09$ \\
\hline $\begin{array}{l}\text { Fuel Hole Diameter, in. } \\
\text { (Dimension E) } \\
\text { (Accuracy: } \pm 0.001 \text { in.) } \\
\frac{\text { Hole No. }}{1} \\
2 \\
3 \\
4 \\
5 \\
6 \\
7 \\
8 \\
\end{array}$ & $\begin{array}{l}0.4995 \\
0.4994 \\
0.4994 \\
0.4994 \\
0.4994 \\
0.4994 \\
0.4994 \\
0.4995 \\
\end{array}$ & $\begin{array}{l}0.4997 \\
0.4994 \\
0.4993 \\
0.4997 \\
0.4997 \\
0.4993 \\
0.4994 \\
0.4996 \\
\end{array}$ & $\begin{array}{l}+0.0002 \\
0 \\
-0.0001 \\
+0.0003 \\
+0.0003 \\
-0.0001 \\
0 \\
+0.0001 \\
\end{array}$ & $\begin{array}{c}+0.04 \\
0 \\
-0.02 \\
+0.06 \\
+0.06 \\
-0.02 \\
0 \\
+0.02\end{array}$ \\
\hline Average & 0.4994 & 0.4995 & +0.0001 & $+0.02=0.20$ \\
\hline
\end{tabular}

(a) Ref. Drawing 11504 
TABLE 14

FTE-3 FUEL BODY DATA (a)

Position in element (Center) 2

Fuel body identification no. $\quad 42$

Graphite $\log$ identification no. 721

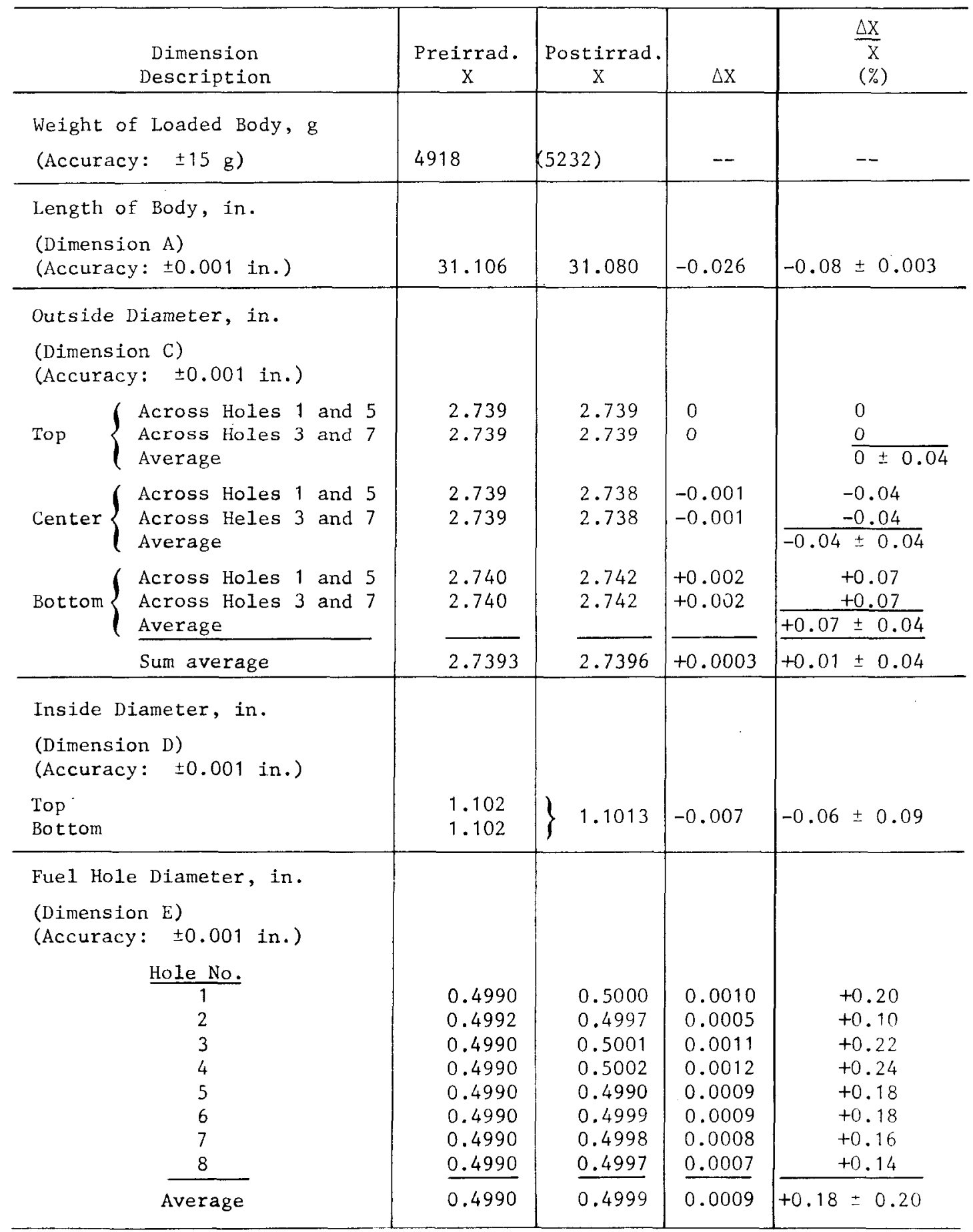

(a) Ref. Drawing 11505 
TABLE 15

FTE-3 FUEL BODY DATA (a)

Position in element (Top) 3

Fuel body identification no. $\quad 39$

Graphite log identification no. 738

\begin{tabular}{|c|c|c|c|c|}
\hline $\begin{array}{l}\text { Dimension } \\
\text { Description }\end{array}$ & $\begin{array}{c}\text { Preirrad. } \\
\text { X }\end{array}$ & $\begin{array}{c}\text { Postirrad. } \\
\text { X }\end{array}$ & $\triangle \mathrm{X}$ & $\frac{\Delta X}{X}$ \\
\hline $\begin{array}{l}\text { Weight of Loaded Body, g } \\
\text { (Accuracy: } \pm 15 \mathrm{~g} \text { ) }\end{array}$ & 4891 & 4900 & 9 & $+0.18 \pm 0.31$ \\
\hline $\begin{array}{l}\text { Length of Body, in. } \\
\text { (Dimension } A \text { ) } \\
\text { (Accuracy: } \pm 0.001 \mathrm{in.})\end{array}$ & 31.103 & 31.085 & -0.018 & $-0.06 \pm 0.003$ \\
\hline $\begin{array}{l}\text { Outside Diameter, in. } \\
\text { (Dimension C) } \\
\text { (Accuracy: } \pm 0.001 \text { in.) }\end{array}$ & & & & \\
\hline Top $\left\{\begin{array}{l}\text { Across Holes } 1 \text { and } 5 \\
\text { Across Holes } 3 \text { and } 7 \\
\text { Average }\end{array}\right.$ & $\begin{array}{l}2.740 \\
2.740\end{array}$ & $\begin{array}{l}2.740 \\
2.741\end{array}$ & $\begin{array}{l}0 \\
+0.001\end{array}$ & $\begin{array}{c}0 \\
+0.04 \\
+0.02 \pm 0.04\end{array}$ \\
\hline Center $\left\{\begin{array}{l}\text { Across Holes } 1 \text { and } 5 \\
\text { Across Holes } 3 \text { and } 7\end{array}\right.$ & $\begin{array}{l}2.740 \\
2.740\end{array}$ & $\begin{array}{l}2.739 \\
2.739\end{array}$ & $\begin{array}{l}-0.001 \\
-0.001\end{array}$ & $\begin{array}{r}-0.04 \\
-0.04 \\
\end{array}$ \\
\hline Bottom $\left\{\begin{array}{l}\text { Across Holes } 1 \text { and } 5 \\
\text { Across Holes } 3 \text { and } 7 \\
\text { Average }\end{array}\right.$ & $\begin{array}{l}2.740 \\
2.740\end{array}$ & $\begin{array}{l}2.741 \\
2.740\end{array}$ & +0.001 & $\begin{array}{c}-0.04 \pm 0.04 \\
+0.04 \\
0 \\
\end{array}$ \\
\hline Sum average & 2.740 & 2.740 & 0 & $0 \pm 0.04$ \\
\hline $\begin{array}{l}\text { Inside Diameter, in. } \\
\text { (Dimension D) } \\
\text { (Accuracy: } \pm 0.001 \text { in.) } \\
\text { Top } \\
\text { Bottom }\end{array}$ & $\begin{array}{l}1.102 \\
1.102\end{array}$ & 1.1013 & -0.0007 & $-0.06 \pm 0.09$ \\
\hline $\begin{array}{l}\text { Fuel Hole Diameter, in. } \\
\text { (Dimension E) } \\
\text { (Accuracy: } \pm 0.001 \text { in.) } \\
\qquad \frac{\text { Hole No. }}{1} \\
2 \\
3 \\
4 \\
5 \\
6 \\
7 \\
8 \\
\end{array}$ & $\begin{array}{l}0.4991 \\
0.4990 \\
0.4990 \\
0.4990 \\
0.4990 \\
0.4990 \\
0.4990 \\
0.4990 \\
\end{array}$ & $\begin{array}{l}0.5002 \\
0.5003 \\
0.4999 \\
0.5001 \\
0.5001 \\
0.4999 \\
0.4997 \\
0.5003 \\
\end{array}$ & $\begin{array}{l}0.0011 \\
0.0013 \\
0.0009 \\
0.0011 \\
0.0011 \\
0.0009 \\
0.0007 \\
0.0013 \\
\end{array}$ & $\begin{array}{l}0.22 \\
0.26 \\
0.18 \\
0.22 \\
0.22 \\
0.18 \\
0.14 \\
0.26 \\
\end{array}$ \\
\hline Average & 0.4990 & 0.5001 & 0.0011 & $+0.21 \pm 0.20$ \\
\hline
\end{tabular}

(a) Ref. Drawing 11506 
TABLE 16

DESCRIPTION AND LOCATION OF SLICES TAKEN FROM FTE-3 GRAPHITE BODIES FOR AUTORADIOGRAPHY

\begin{tabular}{|c|c|c|c|c|}
\hline $\begin{array}{l}\text { Graphite } \\
\text { Body }\end{array}$ & Slice & $\begin{array}{c}\text { Location from Bottom } \\
\text { of Active Core (a) } \\
\text { (in.) }\end{array}$ & $\begin{array}{c}\beta+\gamma \text { Activity } \\
\text { at Contact } \\
(\mathrm{mr} / \mathrm{hr})\end{array}$ & $\begin{array}{c}\text { Spine Sample Occupying } \\
\text { Same Region }\end{array}$ \\
\hline \multicolumn{5}{|l|}{ Top } \\
\hline 3 & 1 & 85.1 & 1000 & Diffusion sample No. 63 \\
\hline 3 & 2 & 79.0 & 110 & Thermal stability sample $2-5$ \\
\hline 2 & 1 & 57.8 & 400 & Graphite spacer No. 24 \\
\hline 2 & 2 & 33.9 & 240 & Diffusion sample No. 61P \\
\hline 1 & 1 & 11.7 & 185 & Diffusion sample No. 30 \\
\hline 1 & 2 & 1.8 & 190 & Stress relaxation sample No. 8 \\
\hline Bottom & & & & \\
\hline
\end{tabular}

(a) Body 1 bottom line $1.30 \mathrm{in}$. under active core height. 
TABLE 17
DESCRTPTION OF FUEL PARTICLES USED FOR FUEL RODS IN FTE-3(a)

\begin{tabular}{|c|c|c|c|c|c|c|c|c|c|c|c|c|c|c|c|c|}
\hline \multirow[b]{2}{*}{ Hole No. } & \multirow[b]{2}{*}{$\begin{array}{l}\text { Particle } \\
\text { Batch No. }\end{array}$} & \multirow[b]{2}{*}{$\begin{array}{c}\text { Kernel } \\
\text { Type }\end{array}$} & \multirow{2}{*}{$\begin{array}{c}\text { Kernel } \\
\text { Size } \\
(\mu \mathrm{m})\end{array}$} & \multirow[b]{2}{*}{$\begin{array}{c}\text { Coating } \\
\text { Type }\end{array}$} & \multicolumn{2}{|c|}{ Buffer (b) } & \multicolumn{2}{|c|}{ Outer Isotropic (b) } & \multicolumn{2}{|c|}{ SiC } & \multicolumn{2}{|c|}{ Inner Isotropic (b) } & \multirow{2}{*}{\multicolumn{2}{|c|}{ Particle Type }} & \multirow[b]{2}{*}{ Blend } & \multirow[b]{2}{*}{$\begin{array}{c}\text { Fue1 Stack } \\
\text { Drawing }\end{array}$} \\
\hline & & & & & $\begin{array}{c}\text { Thickness } \\
(\mu \mathrm{m})\end{array}$ & $\begin{array}{l}\text { Density } \\
\mathrm{g} / \mathrm{cm}^{3}\end{array}$ & $\begin{array}{c}\text { Thickness } \\
(\mu \mathrm{m})\end{array}$ & $\begin{array}{l}\text { Density } \\
8 / \mathrm{cm}^{3}\end{array}$ & $\begin{array}{c}\text { Thickness } \\
(\mathrm{um})\end{array}$ & $\begin{array}{c}\text { Density } \\
\mathrm{g} / \mathrm{cm}^{3}\end{array}$ & $\begin{array}{c}\text { Thickness } \\
(\mu m)\end{array}$ & $\begin{array}{l}\text { Density } \\
\mathrm{g} / \mathrm{cm}^{3}\end{array}$ & & & & \\
\hline 182 & $\begin{array}{l}4000-355 \\
4000-339\end{array}$ & $\begin{array}{r}\mathrm{UO}_{2} \\
\mathrm{ThO}_{2}\end{array}$ & $\begin{array}{l}201 \\
410\end{array}$ & $\begin{array}{l}\text { TRISO-LTI } \\
\text { BISO-LTI }\end{array}$ & $\begin{array}{l}53 \\
62\end{array}$ & $\begin{array}{l}1.29 \\
1.32\end{array}$ & $\begin{array}{l}37 \\
81\end{array}$ & $\begin{array}{l}1.80 \\
1.78\end{array}$ & 23 & $\begin{array}{l}3.20 \\
--\end{array}$ & $\begin{array}{l}27 \\
--\end{array}$ & $\begin{array}{c}1.79 \\
-\end{array}$ & $\begin{array}{ll}\mathrm{UO}_{2} & \text { TRISO } \\
\mathrm{ThO}_{2} & \text { BISO } \\
\mathrm{A}\end{array}$ & \} & $0-1$ & 11403 \\
\hline $3 \& 4$ & $\begin{array}{l}4000-357 \\
4000-345\end{array}$ & $\begin{array}{c}(2.75 \mathrm{Th}: \mathrm{U}) \mathrm{C}_{2} \\
\text { ThI }_{2}\end{array}$ & $\begin{array}{l}211 \\
351\end{array}$ & $\begin{array}{l}\text { TRISO-LII } \\
\text { BISO-LTI }\end{array}$ & $\begin{array}{l}56 \\
63\end{array}$ & $\begin{array}{l}1.24 \\
1.25\end{array}$ & $\begin{array}{l}44 \\
69\end{array}$ & $\begin{array}{l}1.80 \\
1.81\end{array}$ & $\begin{array}{l}27 \\
--\end{array}$ & $\begin{array}{l}3.19 \\
--\end{array}$ & 28 & $\stackrel{1.82}{--}$ & $\begin{array}{c}\left(2.75 \mathrm{Th}^{2} \mathrm{~V}\right) \mathrm{C}_{2} \text { TRISO B } \\
\mathrm{ThC}_{2} \text { BISO A }\end{array}$ & в & M1 & 11401 \\
\hline $5 \& 6$ & $\begin{array}{l}4000-357 \\
4000-335\end{array}$ & $\begin{array}{c}(2.75 \mathrm{Th}: \mathrm{U}) \mathrm{C}_{2} \\
\mathrm{ThC}_{2}\end{array}$ & $\begin{array}{l}211 \\
360\end{array}$ & $\begin{array}{l}\text { TRISO-LTI } \\
\text { TRISO }\end{array}$ & $\begin{array}{l}56 \\
56\end{array}$ & $\begin{array}{l}1.24 \\
1.26\end{array}$ & $\begin{array}{l}44 \\
41\end{array}$ & $\begin{array}{l}1.80 \\
1.79\end{array}$ & $\begin{array}{l}27 \\
28\end{array}$ & $\begin{array}{l}3.19 \\
3.20\end{array}$ & $\begin{array}{l}28 \\
26\end{array}$ & $\begin{array}{l}1.82 \\
1.72\end{array}$ & $\begin{array}{c}(2.75 \mathrm{Th}: \mathrm{U}) \mathrm{C}_{2} \text { TRISO B } \\
\mathrm{ThC}_{2} \text { TRISO A }\end{array}$ & в & LBA1 & 11398 \\
\hline 788 & $\begin{array}{l}4000-358 \\
4000-345\end{array}$ & $\begin{aligned} \mathrm{UC}_{2} \\
\mathrm{ThC}_{2}\end{aligned}$ & $\begin{array}{r}99 \\
351\end{array}$ & $\begin{array}{l}\text { TRISO-LTI } \\
\text { BISO-LTI }\end{array}$ & $\begin{array}{l}57 \\
63\end{array}$ & $\begin{array}{l}1.28 \\
1.25\end{array}$ & $\begin{array}{l}33 \\
69\end{array}$ & $\begin{array}{l}1.79 \\
1.81\end{array}$ & 27 & 3.20 & $\begin{array}{l}27 \\
--\end{array}$ & $\begin{array}{l}1.83 \\
--\end{array}$ & $\begin{array}{l}\mathrm{UC}_{2} \text { TRISO } 95 \\
\mathrm{ThC}_{2} \text { BISO A }\end{array}$ & \} & $\mathrm{F} 1$ & 11409 \\
\hline
\end{tabular}

(a) Identical for all three bodies

(b) propylene was used as coating gas for buffer and 1sotropic coatings on all particles. 
TABLE 18

FUEL ROD DIMENSIONAL CHANGE EVALUATION FOR FTE-3

\begin{tabular}{|c|c|c|c|c|c|c|c|c|}
\hline & \multirow{2}{*}{$\begin{array}{l}\text { Fuel } \\
\text { Rod } \\
\text { No. }\end{array}$} & \multirow{2}{*}{$\begin{array}{l}\text { Active } \\
\text { Core } \\
\text { Height } \\
\text { (In.) }\end{array}$} & \multirow{2}{*}{$\begin{array}{l}\text { Average } \\
\text { Irrad, } \\
\text { Temp. } \\
\left({ }^{\circ} \mathrm{C} \pm 100^{\circ} \mathrm{C}\right)\end{array}$} & \multirow{2}{*}{$\begin{array}{l}\text { Fast Fluence } \\
\left(10^{21} \mathrm{n} / \mathrm{cm}^{-2}\right) \\
(\mathrm{E}>0.18 \mathrm{MeV})\end{array}$} & \multicolumn{4}{|c|}{$\frac{\Delta \mathrm{X}}{\mathrm{X}}$ Average Dimensional Fuel Rod Changes $(\mathrm{a})$} \\
\hline & & & & & $\begin{array}{r}\text { Holes } 1 \\
(\%)\end{array}$ & $\begin{array}{l}\text { Holes } 3 \& 4 \\
(\%)\end{array}$ & $\begin{array}{l}\text { Holes } 5 \& 6 \\
(\%)\end{array}$ & 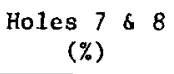 \\
\hline m & $\begin{array}{l}\text { Top } \\
14 \\
13 \\
12 \\
11 \\
10 \\
9 \\
8 \\
7 \\
6 \\
5 \\
4 \\
3 \\
2 \\
1 \\
\text { Avg. }\end{array}$ & $\begin{array}{r}90 \\
89 \\
87 \\
85 \\
83 \\
81 \\
79 \\
77 \\
75 \\
73 \\
71 \\
69 \\
67 \\
65 \\
63 \\
62-90\end{array}$ & $\begin{array}{l}786 \\
789 \\
794 \\
801 \\
808 \\
815 \\
823 \\
831 \\
839 \\
847 \\
855 \\
863 \\
870 \\
877 \\
884 \\
835\end{array}$ & $\begin{array}{l}0.170 \\
0.185 \\
0.210 \\
0.245 \\
0.275 \\
0.300 \\
0.325 \\
0.350 \\
0.375 \\
0.395 \\
0.410 \\
0.430 \\
0.455 \\
0.470 \\
0.485 \\
0.351\end{array}$ & $\begin{array}{l}-- \\
0.93 \\
1.07 \\
1.19 \\
1.28 \\
1.35 \\
1.43 \\
1.49 \\
1.55 \\
1.59 \\
1.64 \\
1.67 \\
1.71 \\
1.75 \\
1.78 \\
1.46\end{array}$ & $\begin{array}{l}-- \\
0.73 \\
0.79 \\
0.85 \\
0.90 \\
0.94 \\
0.98 \\
1.02 \\
1.06 \\
1.08 \\
1.12 \\
1.14 \\
1.17 \\
1.19 \\
1.22 \\
1.01\end{array}$ & $\begin{array}{l}-. \\
0.66 \\
0.71 \\
0.76 \\
0.79 \\
0.82 \\
0.85 \\
0.88 \\
0.91 \\
0.94 \\
0.96 \\
0.98 \\
1.00 \\
1.02 \\
1.04 \\
0.88\end{array}$ & $\begin{array}{l}-- \\
0.84 \\
0.88 \\
0.94 \\
0.99 \\
1.04 \\
1.08 \\
1.11 \\
1.14 \\
1.17 \\
1.19 \\
1.22 \\
1.24 \\
1.26 \\
1.28 \\
1.10\end{array}$ \\
\hline $\begin{array}{l}2 \\
2 \\
0 \\
0 \\
0\end{array}$ & $\begin{array}{c}14 \\
13 \\
12 \\
11 \\
10 \\
\text { T/C Pos } \\
9 \\
8 \\
7 \\
6 \\
5 \\
4 \\
3 \\
2 \\
1 \\
\text { Avg. }\end{array}$ & $\begin{array}{l}58 \\
56 \\
54 \\
52 \\
50 \\
49.5 \\
48 \\
46 \\
44 \\
42 \\
40 \\
38 \\
36 \\
34 \\
32 \\
31-59\end{array}$ & $\begin{array}{l}898 \\
902 \\
906 \\
909 \\
911 \\
911 \\
912 \\
913 \\
912 \\
910 \\
907 \\
903 \\
898 \\
891 \\
883 \\
904\end{array}$ & $\begin{array}{l}0.520 \\
0.530 \\
0.540 \\
0.555 \\
0.565 \\
0.565 \\
0.570 \\
0.575 \\
0.580 \\
0.585 \\
0.590 \\
0.595 \\
0.600 \\
0.600 \\
0.595 \\
0.571\end{array}$ & $\begin{array}{l}1.86 \\
1.88 \\
1.90 \\
1.92 \\
1.94 \\
-9 . \\
1.96 \\
1.96 \\
1.97 \\
1.96 \\
1.95 \\
1.94 \\
1.93 \\
1.90 \\
1.85 \\
1.92\end{array}$ & $\begin{array}{l}1.26 \\
1.28 \\
1.29 \\
1.30 \\
1.31 \\
-- \\
1.32 \\
1.32 \\
1.31 \\
1.30 \\
1.29 \\
1.27 \\
1.25 \\
1.22 \\
1.18 \\
1.28\end{array}$ & $\begin{array}{l}1.08 \\
1.09 \\
1.10 \\
1.11 \\
1.12 \\
-- \\
1.13 \\
1.14 \\
1.14 \\
1.14 \\
1.13 \\
1.12 \\
1.10 \\
1.08 \\
1.06 \\
1.11\end{array}$ & $\begin{array}{l}1.33 \\
1.34 \\
1.36 \\
1.37 \\
1.38 \\
-- \\
1.38 \\
1.39 \\
1.39 \\
1.38 \\
1.38 \\
1.37 \\
1.35 \\
1.32 \\
1.29 \\
1.36\end{array}$ \\
\hline \multirow[t]{2}{*}{$\begin{array}{l}- \\
0 \\
0 \\
0\end{array}$} & $\begin{array}{c}14 \\
13 \\
12 \\
11 \\
10 \\
9 \\
8 \\
7 \\
6 \\
5 \\
4 \\
3 \\
2 \\
1 \\
\text { Bottom } \\
\text { Avg. }\end{array}$ & $\begin{array}{r}27 \\
25 \\
23 \\
21 \\
19 \\
17 \\
15 \\
13 \\
11 \\
9 \\
7 \\
5 \\
3 \\
1 \\
0 \\
0-28\end{array}$ & $\begin{array}{l}857 \\
843 \\
828 \\
812 \\
793 \\
773 \\
751 \\
727 \\
700 \\
672 \\
641 \\
608 \\
573 \\
535 \\
515 \\
669\end{array}$ & $\begin{array}{l}0.580 \\
0.575 \\
0.565 \\
0.550 \\
0.535 \\
0.520 \\
0.505 \\
0.480 \\
0.455 \\
0.420 \\
0.380 \\
0.340 \\
0.250 \\
0.165 \\
0.125 \\
0.451\end{array}$ & $\begin{array}{l}1.72 \\
1.64 \\
1.58 \\
1.50 \\
1.44 \\
1.35 \\
1.27 \\
1.18 \\
1.07 \\
0.94 \\
0.81 \\
0.70 \\
0.62 \\
0.53 \\
=- \\
1.17\end{array}$ & $\begin{array}{l}1.09 \\
1.05 \\
1.00 \\
0.96 \\
0.90 \\
0.85 \\
0.79 \\
0.74 \\
0.67 \\
0.60 \\
0.53 \\
0.45 \\
0.37 \\
0.29 \\
-. \\
0.74\end{array}$ & $\begin{array}{l}0.96 \\
0.92 \\
0.87 \\
0.82 \\
0.77 \\
0.72 \\
0.65 \\
0.59 \\
0.54 \\
0.48 \\
0.44 \\
0.40 \\
0.36 \\
0.34 \\
-- \\
0.63\end{array}$ & $\begin{array}{l}1.22 \\
1.17 \\
1.13 \\
1.08 \\
1.03 \\
0.98 \\
0.92 \\
0.85 \\
0.77 \\
0.67 \\
0.58 \\
0.49 \\
0.41 \\
0.33 \\
--- \\
0.83\end{array}$ \\
\hline & & verage $A$ & stropy & $\frac{\Delta D}{D}$ & 1.050 & 0.909 & 0.932 & 0.760 \\
\hline
\end{tabular}

${ }^{(a)}$ All dimensional changes negative; 1.e., shrinkage 
TABLE 19

FTE-3 ANISOTROPY IN FUEL ROD DIMENSIONAL CHAINGES

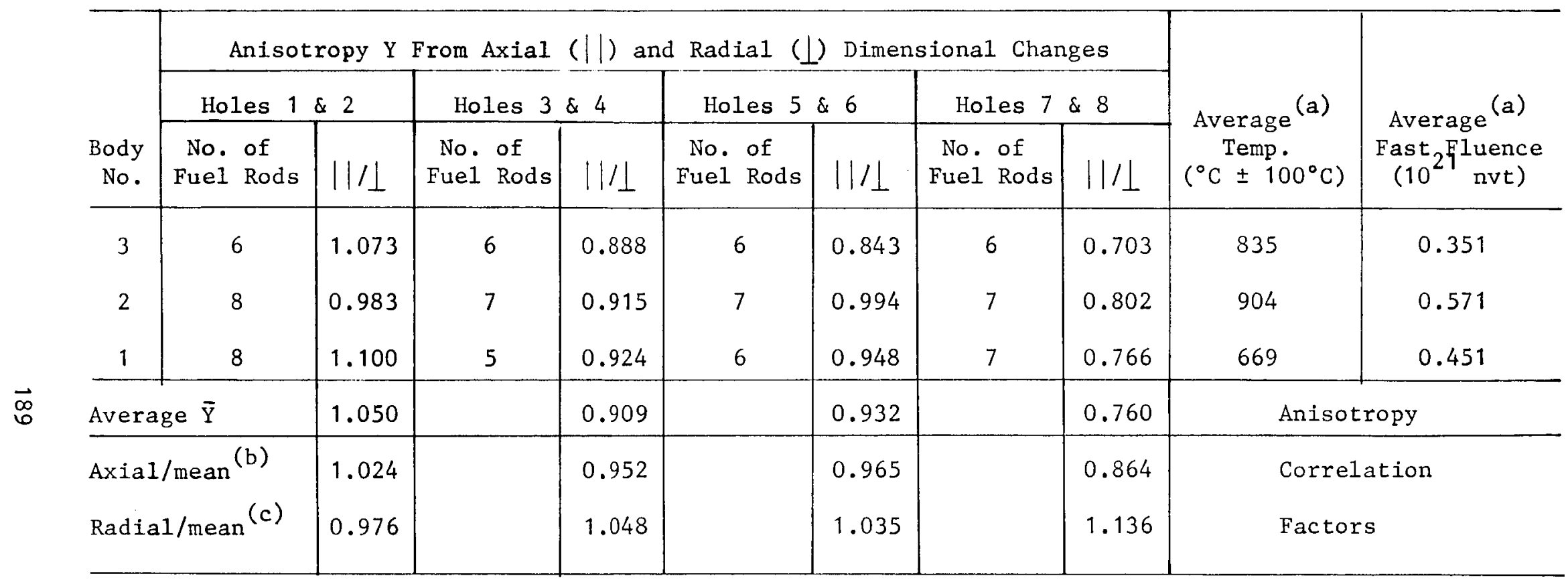

(a) From Table 18 .

(b) Axial/mean dimensional change $=2 \bar{Y} /(1+\bar{Y})$.

(c) Radial/mean dimensional change $=2 /(1+\bar{Y})$. 
TABLE 20

FTE-3 AXIAL GAP INCREASE BETWEEN FUEL RODS

\begin{tabular}{|c|c|c|c|c|c|c|c|c|c|c|c|c|}
\hline \multirow{3}{*}{$\begin{array}{c}\text { Hole } \\
\text { No. }\end{array}$} & \multicolumn{4}{|c|}{ Body 1 (Bottom) } & \multicolumn{4}{|c|}{ Body 2 (Center) } & \multicolumn{4}{|c|}{ Body 3 (Top) } \\
\hline & \multicolumn{2}{|c|}{$\Delta \mathrm{L} / \mathrm{L}(\%)$} & \multirow{2}{*}{$\left(10^{-3^{-}}{ }_{\text {in. })}^{(a)}\right.$} & \multirow{2}{*}{$\begin{array}{c}\Delta \mathrm{Gap}^{(\mathrm{b})} \\
\left(10^{-3} \text { in.) }\right.\end{array}$} & \multicolumn{2}{|c|}{$\Delta \mathrm{L} / \mathrm{L} \quad(\%)$} & \multirow{2}{*}{$\left(10^{\text {Gap }}\right.$ in. $)$} & \multirow{2}{*}{$\begin{array}{c}\Delta \text { Gap } \\
\left(10^{-3} \text { in. }\right)\end{array}$} & \multicolumn{2}{|c|}{$\Delta \mathrm{L} / \mathrm{L} \quad(\%)$} & \multirow{2}{*}{$\left(10^{-\mathrm{G}^{-} \mathrm{p}}\right.$ in. $)$} & \multirow{2}{*}{$\begin{array}{c}\Delta 0^{-3} \text { ap } \\
\text { in. })\end{array}$} \\
\hline & Total $(c)$ & Discrete ${ }^{(d)}$ & & & Total & Discrete & & & Total & Discrete & & \\
\hline $1 \& 2$ & -1.01 & -1.20 & 9.1 & 3.7 & -1.08 & -1.97 & 11.4 & 17.3 & -1.06 & -1.50 & 8.4 & 8.5 \\
\hline $3 \& 4$ & -0.45 & -0.70 & 6.5 & 4.8 & -0.78 & -1.22 & 8.6 & 8.5 & -0.52 & -0.96 & 7.7 & 8.5 \\
\hline $5 \& 6$ & -0.36 & -0.61 & 7.5 & 4.8 & -0.62 & -1.07 & 10.1 & 8.7 & -0.69 & -0.85 & 7.4 & 3.1 \\
\hline $7 \& 8$ & -0.54 & -0.72 & 7.3 & 3.5 & -0.81 & -1.17 & 7.4 & 7.0 & -0.49 & -0.95 & 7.8 & 8.9 \\
\hline Average & -0.59 & -0.81 & 7.6 & 4.2 & -0.82 & -1.36 & 9.4 & 10.4 & -0.69 & -1.07 & 7.8 & 7.3 \\
\hline
\end{tabular}

(a) Sum of 14 individual fuel rod measurements minus total stack length (Table 10, BOL)

(b) $\Delta \mathrm{Gap}=\{(\Delta \mathrm{L} / \mathrm{L})$ total $-(\Delta \mathrm{L} / \mathrm{L})$ discrete $\} *\{1.94 \mathrm{in}$. nominal fuel rod length $\}$.

(c) From total fuel stack via plenum measurements (Table 10).

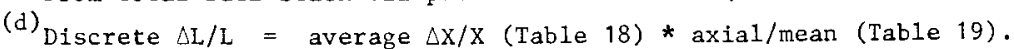


TABLE 21

FTE-3 RADIAL GAP IITCREASE BETWEEN FUEL ROD AiND GRAPHITE

\begin{tabular}{|c|c|c|c|c|c|c|c|c|c|c|c|c|}
\hline \multirow[b]{3}{*}{$\begin{array}{l}\text { Hole } \\
\text { No. }\end{array}$} & \multicolumn{4}{|c|}{ Body 1 (Bottom) } & \multicolumn{4}{|c|}{ Body 2 (Center) } & \multicolumn{4}{|c|}{ Body 3 (Top) } \\
\hline & \multicolumn{2}{|c|}{$\angle D / D(\%)$} & \multirow{2}{*}{$\begin{array}{c}\operatorname{Gap}^{(a)} \\
\left(10^{-3} \text { in. }\right)\end{array}$} & \multirow{2}{*}{$\begin{array}{c}\operatorname{Gap}^{(b)} \\
\left(10^{-3} \text { in. }\right)\end{array}$} & \multicolumn{2}{|c|}{$\Delta \mathrm{D} / \mathrm{D}(\%)$} & \multirow{2}{*}{$\left(10^{-3}\right.$ in. $)$} & \multirow{2}{*}{$\begin{array}{c}\Delta \text { Gap } \\
\left(10^{-3} \text { in. }\right)\end{array}$} & \multicolumn{2}{|c|}{$\Delta \mathrm{D} / \mathrm{D}(\%)$} & \multirow{2}{*}{$\begin{array}{c}\text { Gap } \\
\left(10^{-3} \text { in. }\right)\end{array}$} & \multirow{2}{*}{$\begin{array}{c}\triangle \text { Gap } \\
\left(10^{-3} \mathrm{in.}\right)\end{array}$} \\
\hline & Graphite ${ }^{(c)}$ & Fuel Rod (d) & & & Graphite & Fuel Rod & & & Graphite & Fuel Rod & & \\
\hline $1 \& 2$ & 0 & -1.14 & 4.5 & 2.8 & 0 & -1.87 & 4.5 & 4.6 & 0 & -1.42 & 4.0 & 3.5 \\
\hline $3 \& 4$ & 0 & -0.78 & 4.2 & 1.9 & 0 & -1.34 & 4.1 & 3.3 & 0 & -1.06 & 4.1 & 2.6 \\
\hline $5 \& 6$ & 0 & -0.65 & 4.3 & 1.6 & 0 & -1.15 & 4.1 & 2.8 & 0 & -0.91 & 4.2 & 2.2 \\
\hline $7 \& 8$ & 0 & -0.86 & 4.0 & 2.1 & 0 & -1.54 & 3.8 & 3.8 & 0 & -1.25 & 3.9 & 3.1 \\
\hline Average & 0 & -0.86 & 4.2 & 2.1 & 0 & -1.48 & 4.1 & 3.6 & 0 & -1.16 & 4.0 & 2.8 \\
\hline
\end{tabular}

(a) Fuel hole radius (Tables 13, 14, and 15) minus average measured fuel rod radius (BOL).

(b) $\triangle$ Gap $=\left\{(\Delta D / D)\right.$ graphite $-(\Delta D / D)_{\text {fuel }}$ rod $\} *\{0.245$ in. nominal fuel rod radius $\}$.

(c) Radial change of graphite dimensions from fuel hole diameter measurements (Tables 13, 14, and 15 - taken as 0 because of large inaccuracy).

(d) Fuel $\operatorname{rod}: D / D=$ average $\Delta X / X($ Table 18$) *$ radial $/$ mean (Table 19). 
TABLE 22

COMPOSITION AND FISSION GAS RELEASE R/B DATA FOR FUEL RODS IRRADIATED IN FTE-3

\begin{tabular}{|c|c|c|c|}
\hline Sample & $\begin{array}{c}\text { Fissile Particle } \\
\text { Type }\end{array}$ & $\begin{array}{c}\text { Fertile Particle } \\
\text { Type }\end{array}$ & $\begin{array}{l}\mathrm{Kr} 85 \mathrm{~m} \text { EOL } \mathrm{R} / \mathrm{B} \\
\text { at } 1100^{\circ} \mathrm{C}(\mathrm{a})\end{array}$ \\
\hline $1-2-7$ & $\mathrm{UO}_{2}$ TRISO $\mathrm{B}$ & $\mathrm{ThO}_{2}$ BISO A & $3.4 \times 10^{-6}$ \\
\hline $1-2-8$ & $\mathrm{UO}_{2}$ TRISO B & $\mathrm{ThO}_{2}$ BISO A & $3.7 \times 10^{-6}$ \\
\hline $1-7-6$ & $\mathrm{UC}_{2}$ TRISO 95 & $\mathrm{ThC}_{2}$ BISO A & $1.4 \times 10^{-6}$ \\
\hline $1-7-7$ & $\mathrm{UC}_{2}$ TRISO 95 & $\mathrm{ThC}_{2}$ BISO A & $1.9 \times 10^{-5}$ \\
\hline $1-7-8$ & $\mathrm{UC}_{2}$ TRISO 95 & $\mathrm{ThC}_{2}$ BISO A & $4.0 \times 10^{-5}$ \\
\hline $1-8-7$ & $\mathrm{UC}_{2}$ TRISO 95 & $\mathrm{ThC}_{2}$ BISO A & $3.6 \times 10^{-6}$ \\
\hline $1-8-8$ & $\mathrm{UC}_{2}$ TRISO 95 & $\mathrm{ThC}_{2}$ BISO A & $3.4 \times 10^{-6}$ \\
\hline $2-2-8$ & $\mathrm{UO}_{2}$ TRISO $\mathrm{B}$ & $\mathrm{ThO}_{2}$ BISO A & $4.2 \times 10^{-5}$ \\
\hline $2-5-8$ & $(\mathrm{Th}, \mathrm{U}) \mathrm{C}_{2}$ TRISO $\mathrm{B}$ & $\mathrm{ThC}_{2}$ TRISO A & $2.1 \times 10^{-5}$ \\
\hline $3-1-7$ & $\mathrm{UO}_{2}$ TRISO $\mathrm{B}$ & $\mathrm{ThO}_{2}$ TRISO A & $3.5 \times 10^{-6}$ \\
\hline $3-7-8$ & $\mathrm{UC}_{2}$ TRISO 95 & $\mathrm{ThC}_{2}$ BISO A & $1.2 \times 10^{-5}$ \\
\hline
\end{tabular}

(a) Average R/B of FTE-3 $=1.4 \times 10^{-5}$. 
TABLE 23

RESULTS OF POSTIRRADIATION FISSION GAS RELEASE MEASUREMENTS AND ELECTROLYTIC DISTRIBUTION ACID LEACH STUDIES ON SELECTED FUEL RODS IRRADIATED IN FTE-3

\begin{tabular}{|c|c|c|c|c|c|c|}
\hline $\begin{array}{l}\text { Rod } \\
\text { No. (a) }\end{array}$ & Particle Blend & $\begin{array}{l}\text { Postirradiation } \\
\text { Fission Gas } \\
\text { Release(b) }\end{array}$ & $\begin{array}{l}\text { Current } \\
\text { Density } \\
\left(\mathrm{A} / \mathrm{cm}^{2}\right)\end{array}$ & $\begin{array}{c}\text { Disintegration } \\
\text { Time } \\
(\mathrm{hr})(\mathrm{c})\end{array}$ & $\begin{array}{l}\text { Acid } \\
\text { Leach } \\
\text { Time } \\
\text { (hr) }\end{array}$ & $\begin{array}{c}\text { Fission Product } \\
\text { Isotopes Recovered } \\
\text { (\% of total } \\
\text { inventory) }\end{array}$ \\
\hline $1-2-7$ & $\mathrm{UO}_{2} \mathrm{TRISO} / \mathrm{ThO}_{2}$ BISO & $3.4 \times 10^{-6}$ & -- & - & -- & -- \\
\hline $2-5-8$ & $(\mathrm{Th}, \mathrm{U}) \mathrm{C}_{2} \mathrm{TRISO} / \mathrm{ThC}_{2}$ TRISO & $2.1 \times 10^{-5}$ & -- & -- & - & -- \\
\hline $3-1-7$ & $\mathrm{UO}_{2} \mathrm{TRISO} / \mathrm{ThO}_{2} \mathrm{BISO}$ & $3.5 \times 10^{-6}$ & -- & -- & -- & -- \\
\hline $3-7-8$ & $\mathrm{UC}_{2}$ TRISO $/ \mathrm{ThC}_{2}$ BISO & $1.2 \times 10^{-5}$ & 1.25 & 8 & 14 & $<<1.00^{(\mathrm{d})}$ \\
\hline $2-2-8$ & $\mathrm{UO}_{2}$ TRISO/ThO 2 BISO & $4.2 \times 10^{-5}$ & 1.25 & 10 & 63 & 0.06 \\
\hline $1-2-8$ & $\mathrm{UO}_{2}$ TRISO $\mathrm{ThO}_{2}$ BISO & $3.7 \times 10^{-6}$ & 0.20 & 52 & 2 & 0.20 \\
\hline $1-8-7$ & 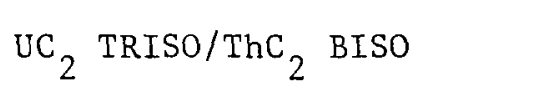 & $3.6 \times 10^{-6}$ & 0.20 & 100 & 2 & $<<1.00^{(\mathrm{d})}$ \\
\hline $1-8-8$ & $\mathrm{UC}_{2}$ TRISO/ThC 2 BISO & $3.4 \times 10^{-6}$ & 1.35 & 6 & 2 & 0.13 \\
\hline
\end{tabular}

(a) First number: fuel body number. Second number: hole number in fuel body. Third number: rod number in rod stack (numbered from bottom).

(b) $\mathrm{R} / \mathrm{B}$ for $\mathrm{Kr}-85 \mathrm{~m}$ at $1100^{\circ} \mathrm{C}$. Not corrected for steady-state conditions.

(c) Temperature of leach solution about $200^{\circ} \mathrm{C}$.

(d) Percentage of recovered isotopes may be considerably lower than 1\%; however, counting errors associated with low concentrations of $\mathrm{Pa}-233$ made analysis of fertile (U-233) particle contributions difficult. 
TABLE 24

TYPE I THERMAL STABILITY SAMPLES IRRADIATED IN FTE-3 AND SUBSEQUENTLY EXAMINED

\begin{tabular}{|c|c|c|c|c|c|c|c|}
\hline \multirow[b]{2}{*}{$\begin{array}{l}\text { Outer } \\
\text { Crucible } \\
\end{array}$} & \multirow[b]{2}{*}{$\begin{array}{c}\text { Inner } \\
\text { Crucible }\end{array}$} & \multirow[b]{2}{*}{ Batch No. } & \multirow[b]{2}{*}{ Particle Type } & \multirow{2}{*}{$\begin{array}{c}\text { No. of } \\
\text { Particles } \\
\text { Tested }\end{array}$} & \multirow[b]{2}{*}{$\begin{array}{l}\text { PIE Radiograph } \\
\text { Plate No. }\end{array}$} & \multicolumn{2}{|c|}{$\begin{array}{l}\text { Calculated } \\
\text { Irradiation Conditions }\end{array}$} \\
\hline & & & & & & $\begin{array}{l}\text { Temp. } \\
\left({ }^{\circ} \mathrm{C}\right)\end{array}$ & $\begin{array}{l}\text { Fast F1uence } \\
\left(\mathrm{x} 10^{21} \mathrm{n} / \mathrm{cm}^{2}\right)\end{array}$ \\
\hline \multirow[t]{2}{*}{$\mathrm{K}$} & \multirow[t]{2}{*}{8} & $4000-302$ & $\mathrm{UC}_{2}$ TRISO & 38 & \multirow[t]{2}{*}{$\mathrm{HA}-88$} & \multirow[t]{2}{*}{873} & \multirow[t]{2}{*}{0.46} \\
\hline & & $4503-63$ & $\mathrm{UC}_{2}$ TRISO & 39 & & & \\
\hline \multirow[t]{2}{*}{$\mathrm{K}$} & \multirow[t]{2}{*}{32} & 4423-33 & $(\mathrm{Th}, \mathrm{U}) \mathrm{C}_{2}$ BISO & 38 & \multirow[t]{2}{*}{$\mathrm{HA}-78$} & \multirow[t]{2}{*}{873} & \multirow[t]{2}{*}{0.46} \\
\hline & & 4423-35 & $(\mathrm{Th}, \mathrm{U}) \mathrm{C}_{2}$ BISO & 39 & & & \\
\hline \multirow[t]{2}{*}{$\mathrm{K}$} & \multirow[t]{2}{*}{38} & $4423-41$ & $(\mathrm{Th}, \mathrm{U}) \mathrm{C}_{2}$ TRISO & 38 & \multirow[t]{2}{*}{$\mathrm{HA}-74$} & \multirow[t]{2}{*}{873} & \multirow[t]{2}{*}{0.46} \\
\hline & & $4423-53$ & $(\mathrm{Th}, \mathrm{U}) \mathrm{C}_{2}$ TRISO & 39 & & & \\
\hline \multirow[t]{2}{*}{$\mathrm{L}$} & \multirow[t]{2}{*}{62} & $4413-127$ & $\mathrm{ThC}_{2}$ BISO & 38 & \multirow[t]{2}{*}{$\mathrm{HA}-86$} & \multirow[t]{2}{*}{851} & \multirow[t]{2}{*}{0.40} \\
\hline & & $4413-149$ & $\mathrm{ThC}_{2}$ BISO & 39 & & & \\
\hline \multirow[t]{2}{*}{$\mathrm{L}$} & \multirow[t]{2}{*}{68} & $4503-59$ & $\mathrm{UO}_{2} \mathrm{BISO}$ & 38 & \multirow[t]{2}{*}{$\mathrm{HA}-76$} & \multirow[t]{2}{*}{851} & \multirow[t]{2}{*}{0.40} \\
\hline & & $4902-5$ & $\mathrm{UC}_{2}$ BISO & 39 & & & \\
\hline \multirow[t]{2}{*}{$\mathrm{L}$} & \multirow[t]{2}{*}{74} & $4503-53$ & $(\mathrm{Th}, \mathrm{U}) \mathrm{C}_{2}$ BISO & 38 & \multirow[t]{2}{*}{$\mathrm{HA}-80$} & \multirow[t]{2}{*}{851} & 0.40 \\
\hline & & $4632-137$ & $(\mathrm{Th}, \mathrm{U}) \mathrm{C}_{2}$ BISO & 39 & & & \\
\hline $\mathrm{L}$ & 80 & $4413-67$ & $\mathrm{UO}_{2}$ TRISO & 38 & $\mathrm{HA}-87$ & 851 & 0.40 \\
\hline & & $4493-149$ & $\mathrm{ThO}_{2}$ BISO & 39 & & & \\
\hline $\mathrm{L}$ & 86 & $3592-35$ & $(\mathrm{Th}, \mathrm{U}) \mathrm{C}_{2}$ TRISO & 38 & $\mathrm{HA}-89$ & 851 & 0.40 \\
\hline & & $4000-195$ & $\mathrm{ThC}_{2}$ TRISO & 39 & & & \\
\hline
\end{tabular}


TABLE 25

TYPE II THERMAL STABILITY SAMPLES IRRADIATED IN FTE-3 AND SUBSEQUENTLY EXAMINED

\begin{tabular}{|c|c|c|c|c|c|c|c|}
\hline \multirow[b]{2}{*}{ Batch No. } & \multirow[b]{2}{*}{ Particle Type } & \multicolumn{3}{|c|}{ Irradiation Conditions } & \multicolumn{3}{|c|}{ Results of Visual Examination } \\
\hline & & Position & $\begin{array}{c}\text { Temp. (a) } \\
\left({ }^{\circ} \mathrm{C}\right)\end{array}$ & $\begin{array}{r}\text { Fast } \\
\text { Fluence (a) } \\
\left(\mathrm{x} \quad 10^{21} \mathrm{n} / \mathrm{cm}^{2}\right) \\
\end{array}$ & $\begin{array}{c}\text { Sample } \\
\text { Size } \\
(\mu \mathrm{m})\end{array}$ & $\begin{array}{l}\text { OPyC Failure } \\
\text { Fraction }(\%)\end{array}$ & $\begin{aligned} & 95 \% \text { Confidence } \\
& \text { Limit } \\
& \text { P }(\%) \\
&\end{aligned}$ \\
\hline $4000-246$ & $\mathrm{UC}_{2} \mathrm{BISO}$ & $5-1$ & 822 & 0.32 & 2600 & 0 & $0 \leq P \leq 0.15$ \\
\hline $4000-300$ & $\mathrm{UC}_{2}$ BISO & $5-2$ & 822 & 0.32 & 3400 & 0 & $0 \leq \mathrm{P} \leq 0.11$ \\
\hline $4000-302$ & $\mathrm{UC}_{2}$ TRISO & $5-5$ & 822 & 0.32 & 2600 & 0 & $0 \leq \mathrm{P} \leq 0.15$ \\
\hline $4503-59$ & $\mathrm{UO}_{2}$ BISO & $5-6$ & 822 & 0.32 & 1900 & 0 & $0 \leq \mathrm{P} \leq 0.20$ \\
\hline $4505-53$ & $(\mathrm{Th}, \mathrm{U}) \mathrm{O}_{2}$ BISO & $11-6$ & 817 & 0.31 & 383 & 0 & $0 \leq \mathrm{P} \leq 0.99$ \\
\hline $4493-149$ & $\mathrm{ThO}_{2}$ BISO & $17-6$ & 837 & 0.37 & 1096 & 0 & $0 \leq P \leq 0.35$ \\
\hline $4423-33$ & $(\mathrm{Th}, \mathrm{U}) \mathrm{C}_{2}$ BISO & $23-1$ & 832 & 0.36 & 557 & 0 & $0 \leq \mathrm{P} \leq 0.69$ \\
\hline $4423-35$ & $(\mathrm{Th}, \mathrm{U}) \mathrm{C}_{2}$ BISO & $23-2$ & 832 & 0.36 & 423 & 0 & $0 \leq \mathrm{P} \leq 0.90$ \\
\hline $4423-41$ & $(\mathrm{Th}, \mathrm{U}) \mathrm{C}_{2}$ TRISO & $23-3$ & 832 & 0.36 & 366 & 0 & $0 \leq P \leq 1.04$ \\
\hline $4423-53$ & $(\mathrm{Th}, \mathrm{U}) \mathrm{C}_{2}$ TRISO & $23-4$ & 832 & 0.36 & 543 & 0 & $0 \leq P \leq 0.70$ \\
\hline $4413-127$ & $\mathrm{ThC}_{2}$ BISO & $29-2$ & 827 & 0.34 & (b) & -- & -- \\
\hline $3592-35$ & $(\mathrm{Th}, \mathrm{U}) \mathrm{C}_{2}$ TRISO & $29-3$ & 827 & 0.34 & (b) & -- & -- \\
\hline $4413-67$ & $\mathrm{UO}_{2}$ TRISO & $29-6$ & 827 & 0.34 & 704 & 0 & $0 \leq P \leq 0.54$ \\
\hline
\end{tabular}

(a) Calculated values.

(b) Visual examination was not performed. 
TABLE 26

DATA ON FTE-3 DLFFUSION SPINE CRUCIBLES

\begin{tabular}{|c|c|c|c|c|c|c|c|c|c|c|}
\hline \multirow[b]{2}{*}{$\begin{array}{l}\text { FTE-3 } \\
\text { Cructble }\end{array}$} & \multicolumn{2}{|c|}{ Temperature } & \multicolumn{2}{|c|}{ Neutron Fluence } & \multicolumn{3}{|c|}{ Load } & \multicolumn{3}{|c|}{ Source Matrix } \\
\hline & $\left({ }^{\circ} \mathrm{C}\right)$ & {$\left[10^{4} / \mathrm{T}\left({ }^{\circ} \mathrm{K}\right)\right]$} & $\begin{array}{c}\text { Thermal } \\
\left(x 10^{21}\right)\end{array}$ & $\begin{array}{l}\text { Fast } \\
\left(\mathrm{x} 10^{21}\right)\end{array}$ & $\begin{array}{l}\text { Mat } \\
\text { Ty }\end{array}$ & $1 x$ & Element & $\begin{array}{l}\text { Conc. } \\
(m g / g)\end{array}$ & Isotope & $(\mathrm{mg} / \mathrm{g})$ \\
\hline 3 & 658 & 10.74 & 0.35 & 0.40 & $R C^{(c)}$ & ${ }_{1}^{(d)}$ & Cs & 3.20 & $\mathrm{Cs}-134$ & $9.5(-2)$ \\
\hline 5 & 813 & 9.21 & 0.34 & 0.29 & $\mathrm{RC}$ & 1 & $\mathrm{Cs}$ & 3.20 & $\mathrm{Cs}-134$ & $9.3(-2)$ \\
\hline 11 & 678 & 10.52 & 0.37 & 0.43 & $\mathrm{RC}$ & 1 & $\mathrm{Sr}_{(\mathrm{Cs})}(e)$ & $\begin{array}{l}0.830 \\
0\end{array}$ & $\begin{array}{l}S z-85 \\
C_{5}-134\end{array}$ & $3.4(-4)$ \\
\hline 16 & 809 & 9.24 & 0.33 & 0.28 & $R C$ & 1 & $\begin{array}{l}\mathrm{Sr} \\
(\mathrm{Cs})\end{array}$ & $\begin{array}{l}0.830 \\
0\end{array}$ & $\begin{array}{l}\mathrm{S} x-85 \\
\mathrm{Cs}-134\end{array}$ & $\begin{array}{l}1.5(-4) \\
4.0(-3)\end{array}$ \\
\hline 24 & 696 & 10.32 & 0.40 & 0.45 & $\mathrm{RC}$ & 1 & $\begin{array}{l}\mathrm{Sm} \\
(\mathrm{Cs})\end{array}$ & $\begin{array}{l}5.92 \\
0\end{array}$ & $\begin{array}{l}E u-154 \\
C_{s}-134\end{array}$ & $\begin{array}{c}1.2(-1) \\
--\end{array}$ \\
\hline 30 & 713 & 10.14 & 0.43 & 0.47 & $\mathrm{RC}$ & & $\mathrm{Ba}$ & 0.065 & $\mathrm{Ba}-133$ & $4.4(-5)$ \\
\hline 42 & 729 & 9.98 & 0.45 & 0.48 & RC & $2^{(f)}$ & $\begin{array}{l}\mathrm{Cs} \\
\mathrm{Sr} \\
\mathrm{Sm} \\
\mathrm{Ba}\end{array}$ & $\begin{array}{l}11.0 \\
6.55 \\
0.329 \\
11.0\end{array}$ & $\begin{array}{l}\mathrm{Cs}-134 \\
\mathrm{~S} r-85 \\
\mathrm{Ba}-154 \\
\mathrm{Ba}-133\end{array}$ & $\begin{array}{l}5.3(-1) \\
2.1(-3) \\
1.1(-1) \\
6.0(-4)\end{array}$ \\
\hline 45 & 803 & 9.29 & 0.32 & 0.26 & $\mathrm{RC}$ & 2 & $\begin{array}{l}\mathrm{Cs} \\
\mathrm{Sr} \\
\mathrm{Sm}\end{array}$ & $\begin{array}{l}0.921 \\
0.460 \\
6.42\end{array}$ & $\begin{array}{l}\mathrm{Cs}-134 \\
S r-85 \\
\mathrm{Eu}-154\end{array}$ & $\begin{array}{l}2.8(-2) \\
6.7(-5) \\
2.6(-3)\end{array}$ \\
\hline 55 & 795 & 9.36 & 0.30 & 0.22 & $R C^{(g)}$ & 2 & $\begin{array}{l}\mathrm{Cs} \\
\mathrm{Sr} \\
\mathrm{Sm} \\
\mathrm{Ba}\end{array}$ & $\begin{array}{r}26.8 \\
5.48 \\
3.14 \\
7.27\end{array}$ & $\begin{array}{l}\mathrm{C} s-134 \\
\mathrm{Sr}-85 \\
\mathrm{Eu}-154 \\
\mathrm{Ba}-133\end{array}$ & $\begin{array}{l}4.0(-1) \\
1.3(-3) \\
1.8(-2) \\
5.0(-4)\end{array}$ \\
\hline 63 & 799 & 9.33 & 0.31 & 0.24 & $\mathrm{CPC}^{(\mathrm{h})}$ & 2 & $\begin{array}{l}\mathrm{Cs} \\
\mathrm{Sr} \\
\mathrm{Sm} \\
\mathrm{Ba}\end{array}$ & $\begin{array}{l}0.508 \\
1.36 \\
1.60 \\
0.844\end{array}$ & $\begin{array}{l}\mathrm{Cs}-134 \\
\mathrm{Sr}-85 \\
\mathrm{Eu}-154 \\
\mathrm{Ba}-133\end{array}$ & $\begin{array}{l}1.2(-2) \\
2.3(-4) \\
1.1(-2) \\
5.0(-4)\end{array}$ \\
\hline 66 & 893 & 8.58 & 0.65 & 0.60 & $\mathrm{CPC}$ & 2 & $\begin{array}{l}\mathrm{Cs} \\
\mathrm{Sr} \\
\mathrm{Sm} \\
\mathrm{Ba}\end{array}$ & $\begin{array}{l}0.508 \\
1.36 \\
1.60 \\
0.844\end{array}$ & $\begin{array}{l}\mathrm{Cs}-134 \\
\mathrm{Sr}-85 \\
\mathrm{Eu}-154 \\
\mathrm{Ba}-133\end{array}$ & $\begin{array}{l}1.3(-2) \\
4.4(-4) \\
4.0(-2) \\
4.9(-4)\end{array}$ \\
\hline
\end{tabular}

(a) Thermal flux $0<\mathrm{E}<2188 \mathrm{eV}$.

(b) Fast flux E $>0.18 \mathrm{MeV}$.

(c) Furfuryl alcohol/resin coke.

(d) Single metallic carbide.

${ }^{(e)} C_{s}$ diffusion from outside noted.

(f) Mixed metallic carbide.

(g) Furfuryl alcohol resin coke with $1 \% \mathrm{MgF}_{2}$ added.

(h) Calcined petroleum coke that contains $20.5 \% \mathrm{~s}$. 
TABLE 27

NUCLEAR TRANSFORMATIONS OF METAL DIFFUSANTS

\begin{tabular}{l|l|l|l}
\hline $\begin{array}{c}\text { Loaded } \\
\text { Species }\end{array}$ & \multicolumn{1}{|c|}{$\begin{array}{c}\text { Isotopic } \\
\text { Conc. (\%) }\end{array}$} & \multicolumn{1}{|c|}{ Nuclear Reaction } & $\begin{array}{c}\text { Product } \\
\text { Species }\end{array}$ \\
\hline $\mathrm{Cs}-133$ & 100 & $\mathrm{n}, \gamma$ & $\mathrm{Cs}-134$ \\
$\mathrm{Sr}-84$ & 82 (enriched) & $\mathrm{n}, \gamma$ & $\mathrm{Sr}-85$ \\
$\mathrm{Sm}-152$ & 99 (enriched) & $\mathrm{n}, \gamma$ Sm-153 B Eu-153 $\mathrm{n}, \gamma$ & $\mathrm{Eu}-154$ \\
$\mathrm{Ba}$ (natural) & $\mathrm{Ba}-133$ tagged & none & $\mathrm{Ba}-133$ \\
\hline
\end{tabular}


TABLE 28

RESULTS OF FTE-3 DATA ANALYSIS OF CONCENTRATION PROFILES - CESIUM FAST COMPONENT

\begin{tabular}{|c|c|c|c|c|c|c|c|}
\hline \multirow[b]{2}{*}{ Sample } & \multicolumn{2}{|c|}{ Temperature } & \multirow{2}{*}{$\begin{array}{c}\mathrm{k} / \mathrm{Q} \\
(\mathrm{cm})\end{array}$} & \multirow{2}{*}{$\begin{array}{c}\mathrm{D}_{\mathrm{e}^{\mathrm{ff}}} \\
\left(\mathrm{cm}^{2} / \mathrm{sec}\right)\end{array}$} & \multirow{2}{*}{$\frac{\mathrm{C}_{\mathrm{f}}^{0}}{\mathrm{Cs}-134}$} & \multirow{2}{*}{$\frac{\phi_{f}}{C_{m} / C_{f}^{0}}$} & \multirow{2}{*}{$\frac{K_{m}}{D_{e f f}\left(\frac{C_{f}^{o}}{C_{m}}\right.}$} \\
\hline & ${ }^{\circ} \mathrm{C}$ & $10^{4} / \mathrm{T}\left({ }^{\circ} \mathrm{K}\right)$ & & & & & \\
\hline 3 center post & 658 & 10.74 & 9.5 & $9 \cdot 2(-9)$ & $8 \cdot 3(-6)$ & 11,400 & $8.1(-13)$ \\
\hline 3 crucible wall & 658 & 10.74 & 66. & $1.33(-9)$ & $3.2(-5)$ & 3,000 & $4.4(-13)$ \\
\hline 11 crucible wall & 678 & 10.52 & 43 & $2.1(-9)$ & -- & - & -- \\
\hline 16 crucible wall & 809 & 9.24 & 58. & $1.5(-9)$ & -- & -- & -- \\
\hline 24 crucible wall & 696 & 10.32 & 42. & $2.1(-9)$ & -- & -- & -- \\
\hline 42 center post & 729 & 9.98 & 3.9 & $2.3(-8)$ & $3.9(-4)$ & 1,360 & $1.69(-11)$ \\
\hline 42 crucible wall & 729 & 9.98 & 4.0 & $2.2(-8)$ & $4.1(-4)$ & 1,290 & $1.71(-11)$ \\
\hline 45 center post & 803 & 9.29 & 2.1 & $4.2(-8)$ & $3.3(-5)$ & 850 & $5.0(-11)$ \\
\hline $45^{(a)}$ crucible wall & 803 & 9.29 & 13.4 & $6.7(-9)$ & -- & -- & -- \\
\hline 55 center post & 795 & 9.36 & 3.1 & $2.8(-8)$ & $1.15(-3)$ & 350 & $8.0(-11)$ \\
\hline 55 crucible wall & 795 & 9.36 & 8.0 & $1.10(-8)$ & $1.3(-3)$ & 310 & $3.5(-11)$ \\
\hline 63 center post & 799 & 9.33 & 3.2 & $2.7(-8)$ & $3.2(-4)$ & $38^{(b)}$ & $7.1(-10)$ \\
\hline 66 center post & 893 & 8.58 & 6.6 & $1.32(-8)$ & $9.2(-4)$ & $14^{(\mathrm{b})}$ & $9 \cdot 3(-10)$ \\
\hline
\end{tabular}

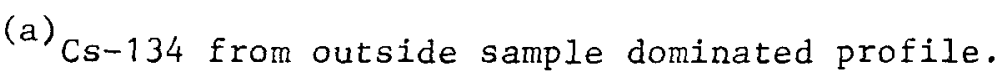

(b) Samples had a calcined petroleum coke matrix, CPC $(20.5 \% \mathrm{~S})$. 
TABLE 29

RESULTS OF ANALYSIS OF FTE-3 CONCENTRATION PROFILES, CESIUM SLOW COMPONENT

\begin{tabular}{|c|c|c|c|c|c|c|c|}
\hline \multirow[b]{2}{*}{ Sample } & \multicolumn{2}{|c|}{ Temperature } & \multirow{2}{*}{$\frac{\mathrm{C}_{\mathrm{m}}}{\mathrm{Cs}-134}$} & \multirow{2}{*}{$\frac{\mathrm{C}_{\mathrm{s}}^{\circ}}{\mathrm{Cs}-134}$} & \multirow{2}{*}{$\begin{array}{r}D t \\
\left(\mathrm{~cm}^{2}\right)\end{array}$} & \multirow{2}{*}{$\frac{\phi_{s}}{C_{m} / C_{s}^{o}}$} & \multirow{2}{*}{$\begin{array}{c}D \\
\left(\mathrm{~cm}^{2} / \mathrm{sec}\right)\end{array}$} \\
\hline & ${ }^{\circ} \mathrm{C}$ & $10^{4} / \mathrm{T}\left({ }^{\circ} \mathrm{K}\right)$ & & & & & \\
\hline 3 center post & 658 & 10.74 & $9.5(-2)$ & $2.8(-4)$ & $1.07(-4)$ & 340 & $9.4(-12)$ \\
\hline $16^{(a)}$ center post & 809 & 9.24 & -- & $3.0(-5)$ & $1.06(-4)$ & -- & $9.3(-12)$ \\
\hline 42 center post & 729 & 9.98 & $5 \cdot 3(-1)$ & $7.0(-3)$ & $3.4(-5)$ & 76 & $3.0(-12)$ \\
\hline 45 center post & 803 & 9.29 & $2.8(-2)$ & $2.1(-4)$ & $5.3(-5)$ & 133 & $4 \cdot 6(-12)$ \\
\hline 63 center post & 799 & 9.33 & $1.2(-2)$ & $7.5(-4)$ & $5.5(-5)$ & $16^{(b)}$ & $4.8(-12)$ \\
\hline
\end{tabular}

(a) Originally no cesium in matrix; cesium observed came from other spine samples.

(b) Sample had a calcined petroleum coke matrix, CPC $(20.5 \% \mathrm{~S})$. 
TABLE 30

RESULTS OF ANALYSIS OF FTE-3 CONCENTRATION PROFILES, STRONTIUM DIFFUSION

\begin{tabular}{|c|c|c|c|c|c|c|c|}
\hline \multirow[b]{2}{*}{ Sample } & \multicolumn{2}{|c|}{ Temperature } & \multirow{2}{*}{$\frac{\mathrm{C}_{\mathrm{m}}}{\mathrm{Sr}-85}$} & \multirow{2}{*}{$\frac{\mathrm{C}_{\mathrm{s}}^{\circ}}{\mathrm{Eu}-154}$} & \multirow{2}{*}{$\begin{array}{l}\mathrm{Dt} \\
\left(\mathrm{cm}^{2}\right)\end{array}$} & \multirow{2}{*}{$\frac{\phi_{s}}{\mathrm{C}_{\mathrm{m}} / \mathrm{C}_{\mathrm{s}}^{0}}$} & \multirow{2}{*}{$\left(\mathrm{cm}^{2} / \mathrm{sec}\right)$} \\
\hline & ${ }^{\circ} \mathrm{C}$ & $10^{4} / \mathrm{T}\left({ }^{\circ} \mathrm{K}\right)$ & & & & & \\
\hline 11 center post & 678 & 10.52 & $3.4(-4)$ & $1.53(-4)$ & $5.2(-5)$ & 2.2 & $4.6(-12)$ \\
\hline 16 center post & 809 & 9.24 & $1.5(-4)$ & $7.4(-5)$ & $9.3(-3)$ & 2.0 & $8.2(-10)$ \\
\hline 16 crucible wall & 809 & 9.24 & $1.5(-4)$ & $6.5(-5)$ & $12.2(-3)$ & 2.3 & $1.07(-9)$ \\
\hline 42 center post & 729 & 9.98 & $2.1(-3)$ & $4.0(-4)$ & $9.3(-4)$ & 5.3 & $8 \cdot 1(-11)$ \\
\hline 42 crucible wall & 729 & 9.98 & $2.1(-3)$ & $3.9(-4)$ & $7.2(-4)$ & 5.4 & $6.3(-11)$ \\
\hline 45 crucible wall & 803 & 9.29 & $6.7(-5)$ & $8.0(-5)$ & $3.3(-3)$ & 0.84 & $2.9(-10)$ \\
\hline 45 center post & 803 & 9.29 & $6.7(-5)$ & $1.01(-4)$ & $2.8(-3)$ & 0.66 & $2.5(-10)$ \\
\hline $55^{(a)}$ center post & 795 & 9.36 & $1.3(-3)$ & $1.42(-5)$ & $4.6(-2)$ & 92 & $4.1(-9)$ \\
\hline${ }_{55}^{(a)}$ crucible wall & 795 & 9.36 & $1.3(-3)$ & $1.86(-5)$ & $1.85(-2)$ & 70 & $1.63(-9)$ \\
\hline
\end{tabular}

(a) At higher matrix concentrations of Strontium, $D$ is larger but $\mathrm{C}_{\mathrm{s}}^{\circ}$ is smaller. 
TABLE 31

RESULTS OF ANALYSIS OF FTE-3 CONCENTRATION PROFILES, EUROPIUM (SAMARIUM) DIFFUSION

\begin{tabular}{|c|c|c|c|c|c|c|c|}
\hline \multirow[b]{2}{*}{ Sample } & \multicolumn{2}{|c|}{ Temperature } & \multirow{2}{*}{$\begin{array}{c}\frac{\mathrm{C}_{\mathrm{m}}}{\mathrm{Ba}-133} \\
(\mathrm{mg} / \mathrm{g})\end{array}$} & \multirow{2}{*}{$\frac{\mathrm{C}_{\mathrm{s}}^{\mathrm{O}}}{\mathrm{Ba}-133}$} & \multirow[b]{2}{*}{$\begin{array}{l}D t \\
\left(\mathrm{~cm}^{2}\right)\end{array}$} & \multirow{2}{*}{$\frac{\phi_{s}}{\mathrm{C}_{\mathrm{m}} / \mathrm{C}_{\mathrm{s}}^{\mathrm{o}}}$} & \multirow{2}{*}{$\left(\mathrm{cm}^{2} / \mathrm{sec}\right)$} \\
\hline & ${ }^{\circ} \mathrm{C}$ & $10^{4} / \mathrm{T}\left({ }^{\circ} \mathrm{K}\right)$ & & & & & \\
\hline 24 center post & 696 & 10.32 & $1.2(-1)$ & $1.27(-2)$ & $1.37(-4)$ & 9.5 & $1.20(-11)$ \\
\hline 24 crucible wall & 696 & 10.32 & $1.2(-1)$ & $8 \cdot 3(-5)$ & $4 \cdot 3(-4)$ & 1500 & $3.8(-11)$ \\
\hline 42 center post & 729 & 9.98 & $1.1(-1)$ & $9.6(-2)$ & $2 \cdot 1(-4)$ & 1.15 & $1.82(-11)$ \\
\hline 42 crucible wall & 729 & 9.98 & $1 \cdot 1(-1)$ & $6.1(-2)$ & $2.1(-4)$ & 1.8 & $1.87(-11)$ \\
\hline 45 center post & 803 & 9.29 & $2.6(-3)$ & $3.1(-3)$ & $0.143(-3)$ & 0.84 & $1.25(-10)$ \\
\hline 45 crucible wall & 803 & 9.29 & $2.6(-3)$ & $2.6(-3)$ & $1 \cdot 3(-3)$ & 1.0 & $1.15(-10)$ \\
\hline $55^{(\mathrm{a})}$ center post & 795 & 9.36 & $1.8(-2)$ & $1.70(-3)$ & $1.21(-2)$ & 10.6 & $1.06(-9)$ \\
\hline $55^{(a)}$ crucible wall & 795 & 9.36 & $1.8(-2)$ & $1.94(-3)$ & $8.6(-3)$ & 9.3 & $7.6(-10)$ \\
\hline
\end{tabular}

(a) At higher matrix concentrations of Europium, $D$ is larger but $C_{s}^{\circ}$ is smaller. 
TABLE 32

RESULTS OF ANALYSIS OF FTE-3 CONCENTRATION PROFILES BARIUM DIFFUSION

\begin{tabular}{|c|c|c|c|c|c|c|c|}
\hline \multirow[b]{2}{*}{ Sample } & \multicolumn{2}{|c|}{ Temperature } & \multirow{2}{*}{$\begin{array}{c}\frac{\mathrm{C}_{\mathrm{m}}}{\mathrm{Ba}-133} \\
(\mathrm{mg} / \mathrm{g})\end{array}$} & \multirow{2}{*}{ 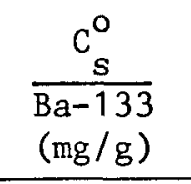 } & \multirow{2}{*}{$\begin{array}{c}\mathrm{Dt} \\
\left(\mathrm{cm}^{2}\right)\end{array}$} & \multirow{2}{*}{$\frac{\phi_{s}}{C_{m} / C_{s}^{0}}$} & \multirow{2}{*}{$\begin{array}{c}D \\
\left(\mathrm{~cm}^{2} / \mathrm{sec}\right)\end{array}$} \\
\hline & $\left({ }^{\circ} \mathrm{C}\right)$ & {$\left[10^{4} / \mathrm{T}\left({ }^{\circ} \mathrm{K}\right)\right]$} & & & & & \\
\hline 42 center post & 729 & 9.98 & $6.0(-4)$ & $9.2(-6)$ & $4.8(-4)$ & 65 & $4 \cdot 2(-11)$ \\
\hline 42 crucible wall & 729 & 9.98 & $6.0(-4)$ & $7.1(-6)$ & $5.2(-4)$ & 85 & $4.5(-11)$ \\
\hline $45^{(a)}$ center post & 803 & 9.29 & $3.0(-4)$ & $1.3(-5)$ & $1.45(-5)$ & 23 & $1.27(-9)$ \\
\hline 45 crucible wall & 803 & 9.29 & $3.0(-4)$ & $1.60(-5)$ & $2.91(-3)$ & 19 & $2.6(-10)$ \\
\hline $55^{\text {(b) }}$ center post & 795 & 9.36 & $5.0(-4)$ & $5.8(-6)$ & $2.4(-2)$ & 86 & $2.1(-9)$ \\
\hline $55^{(\mathrm{b})}$ crucible wall & 795 & 9.36 & $5.0(-4)$ & $1.01(-5)$ & $8.7(-3)$ & 50 & $7.6(-10)$ \\
\hline
\end{tabular}

(a) $D$ calculated high because of back diffusion contribution to profile.

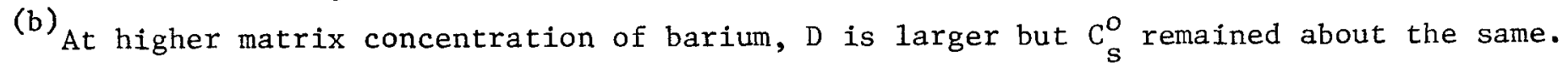


TABLE 33

DESCRIPTION OF FUEL PARTICLES USED IN GRAPHITE CAINED FISSION PRODUCT RELEASE SAMPLES IRRADLATED IN FTE-3

\begin{tabular}{|c|c|c|c|c|c|c|c|c|c|c|}
\hline \multirow[b]{2}{*}{$\begin{array}{l}\text { Crucible } \\
\text { No. }\end{array}$} & \multirow{2}{*}{$\begin{array}{l}\text { Particle } \\
\text { Batch } \\
\text { INo. }\end{array}$} & \multirow[b]{2}{*}{$\begin{array}{c}\text { Kernel } \\
\text { Type }\end{array}$} & \multirow{2}{*}{$\begin{array}{c}\text { Kernel } \\
\text { Size } \\
(\mu \mathrm{m})\end{array}$} & \multirow[b]{2}{*}{$\begin{array}{l}\text { Coating } \\
\text { Type }\end{array}$} & \multicolumn{2}{|c|}{ Buffer } & \multicolumn{2}{|c|}{ Outer Isotropic } & \multicolumn{2}{|c|}{ Coating Gas } \\
\hline & & & & & $\begin{array}{l}\text { Thickness } \\
(\mu \mathrm{m})\end{array}$ & $\begin{array}{l}\text { Density } \\
\left(\mathrm{g} / \mathrm{cm}^{3}\right)\end{array}$ & $\begin{array}{l}\text { Thickness } \\
\quad(i ⿴ 囗))\end{array}$ & $\begin{array}{l}\text { Density } \\
\left(\mathrm{g} / \mathrm{cm}^{3}\right)\end{array}$ & Buffer & $\begin{array}{l}\text { Isotropic } \\
\text { Coating }\end{array}$ \\
\hline $8 \mathrm{P}$ & $4000-227$ & $(\mathrm{Th}, \mathrm{U}) \mathrm{C}_{2}{ }^{(\mathrm{a})}$ & 193 & BISO-LTI & 40 & 1.20 & 72 & 1.85 & Propylene & Propylene \\
\hline $11 \mathrm{P}$ & $4000-227$ & $(\mathrm{Th}, \mathrm{U}) \mathrm{C}_{2}$ & 193 & BISO-LTI & 40 & 1.20 & 72 & 1.85 & Propylene & Propylene \\
\hline $24 \mathrm{P}$ & $4000-232$ & $(\mathrm{Th}, \mathrm{U}) \mathrm{C}_{2}{ }^{(\mathrm{a})}$ & 198 & TRISO-LTI ${ }^{(b)}$ & 51 & 1.06 & 38 & 1.78 & Acetylene & Propylene \\
\hline $28 \mathrm{P}$ & $4000-232$ & $(\mathrm{Th}, \mathrm{U}) \mathrm{C}_{2}$ & 198 & TRISO-LTI & 51 & 1.06 & 38 & 1.78 & Acetylene & Propylene \\
\hline $43 P$ & $4632-137$ & $(\mathrm{Th}, \mathrm{U}) \mathrm{C}_{2}{ }^{(\mathrm{a})}$ & 200 & $\begin{array}{l}\text { BISO-LTI } \\
\text { Si Doped }\end{array}$ & 46 & 1.22 & 72 & 2.18 & Propylene & Propylene \\
\hline $58 \mathrm{P}$ & $4503-53$ & $(\mathrm{Th}, \mathrm{U}) \mathrm{O}_{2}{ }^{(\mathrm{a})}$ & 360 & BISO-LTI & 90 & 1.24 & 124 & 1.64 & Propylene & Propylene \\
\hline $75 \mathrm{P}$ & $4000-300$ & $\mathrm{UC}_{2}$ & 100 & BISO-LTI & 49 & 1.35 & 74 & 1.85 & Propylene & Propylene \\
\hline $92 \mathrm{P}$ & $4000-302$ & $\mathrm{Uc}_{2}$ & 100 & TRISO-LTI ${ }^{(c)}$ & 50 & 1.31 & 36 & 1.71 & Acetylene & Propylene \\
\hline $117 \mathrm{P}$ & $4000-225$ & $\operatorname{ThC}_{2}$ & 350 & BISO-LTI & 49 & 1.21 & 66 & 1.88 & Propylene & Propylene \\
\hline $120 P$ & $4000-242$ & $\mathrm{ThC}_{2}$ & 384 & TRISO-LII ${ }^{(d)}$ & 46 & 1.12 & 42 & 1.70 & Acetylene & Propylene \\
\hline $144 \mathrm{P}$ & $4503-59$ & $\mathrm{UO}_{2}$ & 232 & BISO-LTI & 50 & 1.30 & 70 & 1.83 & Propylene & Propylene \\
\hline 1478 & $4503-59$ & $\mathrm{UO}_{2}$ & 232 & BISO-LTI & 50 & 1.30 & 70 & 1.83 & Propylene & Propylene \\
\hline $166 \mathrm{P}$ & $4493-149$ & $\mathrm{ThO}_{2}$ & 375 & BISO-LTI & 46 & 1.33 & 70 & 1.85 & Propylene & Propylene \\
\hline
\end{tabular}

(a) $\mathrm{Th} / \mathrm{U}$ ratio $=2$.

(b) Inner isotropic coating thickness $=19 \mu \mathrm{m}$, density $=1.86 \mathrm{~g} / \mathrm{cm}^{3} ;$ Sic thickness $=21 \mathrm{\mu m}$, density $=3.21 \mathrm{~g} / \mathrm{cm}^{3}$.

(c) Inner isotropic coating thickness $=18 \mathrm{wm}$, density $=1.84 \mathrm{~g} / \mathrm{cm}^{3} ;$ SiC thickness $=20 \mu \mathrm{m}$, density $=3.19 \mathrm{~g} / \mathrm{cm}^{3}$.

(d) Inner isotropic coating thickness $=28 \mathrm{\mu m}$, density $=1.80 \mathrm{~g} / \mathrm{cm}^{3} ;$ SiC thickness $=23 \mathrm{jm}$, density $=3.19 \mathrm{~g} / \mathrm{cm}^{3}$. 
TABLE 34

CESIUM PARTITION COEFFICIENTS FROM FTE- 3 FISSION PRODUCT RELEASE SAMPLES

\begin{tabular}{|c|c|c|c|c|c|c|c|c|c|c|c|}
\hline \multirow[b]{3}{*}{ Sample } & \multirow{3}{*}{$\begin{array}{c}\text { Irradiation } \\
\text { Temp. } \\
\left({ }^{\circ} \mathrm{C}\right)\end{array}$} & \multirow{3}{*}{$\begin{array}{l}\text { Therma1 } \\
\text { Fluence } \\
\left(x \quad 10^{21}\right)\end{array}$} & \multirow{3}{*}{$\begin{array}{c}\text { Fast } \\
\text { Fluence } \\
\left(x \quad 10^{21}\right)\end{array}$} & \multicolumn{4}{|c|}{ Inner Crucible } & \multicolumn{4}{|c|}{ Outer Crucible } \\
\hline & & & & \multicolumn{2}{|c|}{$\phi_{S}^{(a)}$} & \multicolumn{2}{|c|}{$\phi_{\mathrm{f}}(\mathrm{b})$} & \multicolumn{2}{|c|}{$\phi_{S}(a)$} & \multicolumn{2}{|c|}{$\phi_{f}(\mathrm{~b})$} \\
\hline & & & & $\mathrm{Cs}-134$ & $\mathrm{Cs}-137$ & Cs -134 & $\mathrm{Cs}-137$ & Cs -134 & $\mathrm{Cs}-137$ & $C s-134$ & Cs -137 \\
\hline $8 \mathrm{P}$ & 820 & 0.60 & 0.56 & 2.3 & -- & 23.5 & -- & 7.7 & -- & 35.2 & -- \\
\hline $11 \mathrm{P}$ & 911 & 0.66 & 0.57 & 5.4 & 4.1 & 18.0 & 6.5 & -- & 4.3 & 27.0 & 6.5 \\
\hline $24 \mathrm{P}$ & 809 & 0.59 & 0.55 & 4.8 & $<1$ & 35.7 & 3.2 & 16.2 & $<1$ & 71.3 & 4.0 \\
\hline $28 \mathrm{P}$ & 909 & 0.65 & 0.56 & $<1$ & -- & 2.5 & 4.6 & 2.0 & 4.6 & 5.0 & 4.6 \\
\hline $43 \mathrm{P}$ & 905 & 0.64 & 0.54 & $<1$ & -- & $<1$ & -- & $<1$ & -- & $<1$ & -- \\
\hline $58 \mathrm{P}$ & 791 & 0.30 & 0.20 & 14.5 & -- & 54.3 & -- & 10.9 & -- & 43.4 & -- \\
\hline $75 P$ & 785 & 0.56 & 0.53 & $<1$ & $<1$ & 2.2 & 9.8 & 1.8 & 8.4 & 8.8 & 14.8 \\
\hline $92 \mathrm{P}$ & 789 & 0.31 & 0.18 & 7.3 & -- & 33.0 & -- & 4.0 & -- & 28.3 & -- \\
\hline $107 \mathrm{P}$ & 830 & 0.62 & 0.56 & $<1$ & 2.2 & 5.5 & 14.0 & 1.7 & 9.3 & 8.3 & 18.6 \\
\hline $120 \mathrm{P}$ & 840 & 0.62 & 0.57 & $<1$ & $<1$ & 8.2 & 16.8 & 3.7 & 3.1 & 12.3 & 33.6 \\
\hline $144 \mathrm{P}$ & 797 & 0.58 & 0.54 & 140 & -- & -- & -- & 1.4 & 1.4 & 8.4 & 22.8 \\
\hline $147 \mathrm{P}$ & 901 & 0.62 & 0.53 & $<1$ & 1.6 & 2.5 & 5.2 & 2.1 & 4.1 & 5.0 & 8.6 \\
\hline $166 \mathrm{P}$ & 849 & 0.63 & 0.58 & 1.4 & -- & 9.6 & -- & 2.9 & -- & 14.4 & -- \\
\hline
\end{tabular}

${ }^{(a)} \phi_{S}=$ ratio of matrix concentration to crucible wall concentration at interface between matrix and wall for slow component of diffusion profile.

${ }^{(b)} \phi_{f}=$ ratio of matrix concentration to crucible wall concentration at interface between matrix and wall for fast component of diffusion profile. 
TABLE 35

DESCRIPTION OF FUEL PARTICLES USED IN NIOBIUM-CANNED FISSION PRODUCT RELEASE SAMPLES IRRADIATED IN FTE-3

\begin{tabular}{|c|c|c|c|c|c|c|c|c|c|c|}
\hline \multirow[b]{3}{*}{$\begin{array}{c}\text { Crucible } \\
\text { No. }\end{array}$} & \multirow{3}{*}{$\begin{array}{c}\text { Particle } \\
\text { Batch } \\
\text { No. }\end{array}$} & \multirow[b]{3}{*}{$\begin{array}{c}\text { Kernel } \\
\text { Type }\end{array}$} & \multirow{3}{*}{$\begin{array}{c}\text { Kernel } \\
\text { Size } \\
(\mu \mathrm{m})\end{array}$} & \multirow[b]{3}{*}{$\begin{array}{l}\text { Coating } \\
\text { Type }\end{array}$} & \multicolumn{2}{|c|}{ Buffer } & \multicolumn{2}{|c|}{ Outer Isotropic } & \multirow{2}{*}{\multicolumn{2}{|c|}{ Coating Gas }} \\
\hline & & & & & \multirow{2}{*}{$\begin{array}{c}\text { Thick- } \\
\text { ness } \\
(\mu \mathrm{m})\end{array}$} & \multirow[b]{2}{*}{$\begin{array}{r}\text { Density } \\
\left(\mathrm{g} / \mathrm{cm}^{3}\right)\end{array}$} & \multirow{2}{*}{$\begin{array}{c}\text { Thick- } \\
\text { ness } \\
(\mu \mathrm{m})\end{array}$} & \multirow[b]{2}{*}{$\begin{array}{r}\text { Density } \\
\left(\mathrm{g} / \mathrm{cm}^{3}\right)\end{array}$} & & \\
\hline & & & & & & & & & Buffer & $\begin{array}{c}\text { Isotropic } \\
\text { Coating }\end{array}$ \\
\hline $\mathrm{Nb}-3$ & $4000-227$ & $(\mathrm{Th}, \mathrm{U}) \mathrm{C}_{2}{ }^{(\mathrm{a})}$ & 193 & BISO-LTI & 40 & 1.20 & 72 & 1.85 & Propylene & Propylene \\
\hline $\mathrm{Nb}-6$ & $4000-232$ & $(\mathrm{Th}, \mathrm{U}) \mathrm{C}_{2}{ }^{(\mathrm{a})}$ & 198 & TRISO-LTI ${ }^{(b)}$ & 51 & 1.06 & 38 & 1.78 & Acetylene & Propy lene \\
\hline $\mathrm{Nb}-14$ & $4503-59$ & $\mathrm{UO}_{2}$ & 232 & BISO-LTI & 50 & 1.30 & 70 & 1.83 & Propylene & Propylene \\
\hline
\end{tabular}

(a) $\mathrm{Th} / \mathrm{U}=2$.

(b) Inner isotropic coating thickness $=19 \mu \mathrm{m}$, density $=1.86 \mathrm{~g} / \mathrm{cm}^{3} ;$ SiC coating thickness $=21 \mu \mathrm{m}$, density $=3.21 \mathrm{~g} / \mathrm{cm}^{3}$. 
TABLE 36

THERMAL ANALYSIS OF NIOBIUM-CANNED FISSION PRODUCT RELEASE SAMPLES

(NOS. $\mathrm{Nb}-3, \mathrm{Nb}-6, \mathrm{Nb}-10$, AND Nb-14) IRRADIATED IN FTE-3

\begin{tabular}{l|r}
\hline \multicolumn{1}{c|}{ Component } & Temperature Range $\left({ }^{\circ} \mathrm{C}\right)$ \\
\hline Niobium crucible & 1187 to 1194 \\
Graphoil and niobium foils & 1205 to 1219 \\
Graphite crucible & 1250 to 1274 \\
Coke material & 1252 to 1270 \\
Fuel particles & 1349 to 1371 \\
\hline
\end{tabular}


TABLE 37

DISTRIBUTION OF Cs-137, Ce-144, AND Zr-95 IN FISSION PRODUCT RELEASE SAMPLES IRRADIATED IN FTE-3

\begin{tabular}{|c|c|c|c|c|c|c|c|c|c|}
\hline \multirow{3}{*}{$\begin{array}{c}\text { Fuel } \\
\text { Particle } \\
\text { Sample } \\
\end{array}$} & \multirow[b]{3}{*}{ Nuclide } & \multicolumn{8}{|c|}{ Distribution of Fission Product Nuclide(a) } \\
\hline & & \multicolumn{2}{|c|}{ Fuel Particles } & \multicolumn{2}{|c|}{ Coke ${ }^{(b)}$} & \multicolumn{2}{|c|}{ Graphite Crucible } & \multicolumn{2}{|c|}{ Graphoil } \\
\hline & & $(\mathrm{mg} / \mathrm{g})$ & Fract. & $(\mathrm{mg} / \mathrm{g})$ & Fract. & $(\mathrm{mg} / \mathrm{g})$ & Fract. & (mg/g) & Fract. \\
\hline $\begin{array}{l}\mathrm{Nb}-3, \mathrm{BISO} \\
\text { coated }(\mathrm{Th}, \mathrm{U}) \mathrm{C}_{2}\end{array}$ & $\begin{array}{l}\mathrm{Cs}-137 \\
\mathrm{Ce}-144 \\
\mathrm{Zr}-95\end{array}$ & $\begin{array}{l}4.8(-1)(c) \\
2.1(-1) \\
1.4(-1)\end{array}$ & $\begin{array}{l}0.94 \\
0.81 \\
0.96\end{array}$ & $\begin{array}{l}2.9(-2) \\
1.9(-2) \\
4.9(-3)\end{array}$ & $\begin{array}{l}0.057 \\
0.074 \\
0.034\end{array}$ & $\begin{array}{l}4.2(-4) \\
6.3(-3) \\
2.7(-4)\end{array}$ & $\begin{array}{l}0.001 \\
0.024 \\
0.002\end{array}$ & $\begin{array}{l}1.7(-3) \\
2.4(-2) \\
1.3(-3)\end{array}$ & $\begin{array}{l}0.003 \\
0.095 \\
0.009\end{array}$ \\
\hline $\begin{array}{l}\mathrm{Nb}-6, \text { TRISO } \\
\text { coated }(\mathrm{Th}, \mathrm{U}) \mathrm{C}_{2}\end{array}$ & $\begin{array}{l}\mathrm{Cs}-137 \\
\mathrm{Ce}-144 \\
\mathrm{Zr}-95\end{array}$ & $\begin{array}{l}4.0(-1) \\
2.2(-1) \\
8.6(-2)\end{array}$ & $\begin{array}{l}0.97 \\
0.93 \\
0.98\end{array}$ & $\begin{array}{l}1.1(-2) \\
7.4(-3) \\
1.7(-3)\end{array}$ & $\begin{array}{l}0.028 \\
0.032 \\
0.019\end{array}$ & $\begin{array}{l}7.6(-5) \\
9.0(-4) \\
5.1(-5)\end{array}$ & $\begin{array}{r}<0.001 \\
0.004 \\
0.001\end{array}$ & $\begin{array}{l}2.9(-4) \\
7.7(-3) \\
2.5(-4)\end{array}$ & $\begin{array}{l}0.001 \\
0.033 \\
0.003\end{array}$ \\
\hline $\begin{array}{l}\mathrm{Nb}-10, \text { BISO (Si) } \\
\text { coated }(\mathrm{Th}, \mathrm{U}) \mathrm{C}_{2}\end{array}$ & $\begin{array}{l}\mathrm{Cs}-137 \\
\mathrm{Ce}-144 \\
\mathrm{Zr}-95\end{array}$ & $\begin{array}{l}3.6(-1) \\
1.8(-1) \\
9.6(-2)\end{array}$ & $\begin{array}{l}0.84 \\
0.81 \\
0.80\end{array}$ & $\begin{array}{l}5.9(-2) \\
2.0(-2) \\
\quad(\mathrm{d})\end{array}$ & $\begin{array}{l}0.14 \\
0.088 \\
\text { (d) }\end{array}$ & $\begin{array}{l}1.5(-3) \\
7.8(-3) \\
1.0(-3)\end{array}$ & $\begin{array}{l}0.003 \\
0.035 \\
0.008\end{array}$ & $\begin{array}{c}1.0(-2) \\
1.4(-2) \\
(d)\end{array}$ & $\begin{array}{l}0.03 \\
0.063 \\
\text { (d) }\end{array}$ \\
\hline $\begin{array}{ll}\mathrm{Nb}-14, & \text { BISO } \\
\text { coated } \mathrm{UO}_{2}\end{array}$ & $\begin{array}{l}\mathrm{Cs}-137 \\
\mathrm{Ce}-144 \\
\mathrm{Zr}-95\end{array}$ & $\begin{array}{l}3.2(-1) \\
2.4(-1) \\
1.2(-1)\end{array}$ & $\begin{array}{l}0.33 \\
0.97 \\
0.99\end{array}$ & $\begin{array}{c}5.9(-1) \\
\text { (e) } \\
\text { (e) }\end{array}$ & $\begin{array}{r}0.61 \\
(\mathrm{e}) \\
(\mathrm{e})\end{array}$ & $\begin{array}{l}7.5(-3) \\
1.2(-3) \\
1.0(-4)\end{array}$ & $\begin{array}{l}0.008 \\
0.005 \\
0.001\end{array}$ & $\begin{array}{l}5.7(-2) \\
7.2(-3) \\
5.2(-4)\end{array}$ & $\begin{array}{l}0.06 \\
0.029 \\
0.004\end{array}$ \\
\hline
\end{tabular}
(a) $\mathrm{Frac}$
(b) Petroleun coke.
(c) $4.8(-1)$ means $4.8 \times 10^{-1}$.
(d) Component samples being recounted.
(e) Below limits of detection. 